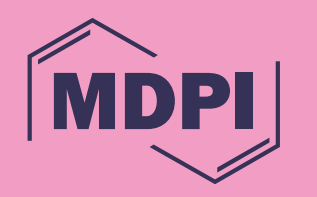

\title{
Transitioning to QUALITY EDUCATION
}

Eila Jeronen (Ed.) 


\section{Transitioning to Quality Education}




\title{
Transitioning to Sustainability Series: Volume 4
}

\author{
Series Editor: Manfred Max Bergman
}

Volumes in the series:

Volume 1: Transitioning to No Poverty

ISBN 978-3-03897-860-2 (Hbk);

ISBN 978-3-03897-861-9 (PDF)

Volume 2: Transitioning to Zero Hunger ISBN 978-3-03897-862-6 (Hbk);

ISBN 978-3-03897-863-3 (PDF)

Volume 3: Transitioning to Good Health and Well-Being

ISBN 978-3-03897-864-0 (Hbk);

ISBN 978-3-03897-865-7 (PDF)

Volume 4: Transitioning to Quality

Education

ISBN 978-3-03897-892-3 (Hbk);

ISBN 978-3-03897-893-0 (PDF)

Volume 5: Transitioning to Gender Equality ISBN 978-3-03897-866-4 (Hbk);

ISBN 978-3-03897-867-1 (PDF)

Volume 6: Transitioning to Clean Water and Sanitation

ISBN 978-3-03897-774-2 (Hbk);

ISBN 978-3-03897-775-9 (PDF)

Volume 7: Transitioning to Affordable and Clean Energy

ISBN 978-3-03897-776-6 (Hbk);

ISBN 978-3-03897-777-3 (PDF)

Volume 8: Transitioning to Decent Work and Economic Growth

ISBN 978-3-03897-778-0 (Hbk);

ISBN 978-3-03897-779-7 (PDF)

Volume 9: Transitioning to Sustainable Industry, Innovation and Infrastructure ISBN 978-3-03897-868-8 (Hbk);

ISBN 978-3-03897-869-5 (PDF)
Volume 10: Transitioning to Reduced Inequalities ISBN 978-3-03921-160-9 (Hbk); ISBN 978-3-03921-161-6 (PDF)

Volume 11: Transitioning to Sustainable Cities and Communities ISBN 978-3-03897-870-1 (Hbk); ISBN 978-3-03897-871-8 (PDF)

Volume 12: Transitioning to Responsible Consumption and Production ISBN 978-3-03897-872-5 (Hbk); ISBN 978-3-03897-873-2 (PDF)

Volume 13: Transitioning to Climate Action ISBN 978-3-03897-874-9 (Hbk); ISBN 978-3-03897-875-6 (PDF)

Volume 14: Transitioning to Sustainable Life below Water

ISBN 978-3-03897-876-3 (Hbk);

ISBN 978-3-03897-877-0 (PDF)

Volume 15: Transitioning to Sustainable Life on Land

ISBN 978-3-03897-878-7 (Hbk);

ISBN 978-3-03897-879-4 (PDF)

Volume 16: Transitioning to Peace, Justice and Strong Institutions

ISBN 978-3-03897-880-0 (Hbk);

ISBN 978-3-03897-881-7 (PDF)

Volume 17: Transitioning to Strong Partnerships for the Sustainable Development Goals ISBN 978-3-03897-882-4 (Hbk); ISBN 978-3-03897-883-1 (PDF) 
Eila Jeronen (Ed.)

\section{Transitioning to Quality Education}

Transitioning to Sustainability Series 
EDITOR

Eila Jeronen

University of Oulu,

University of Lapland,

University of Helsinki,

Finland
EDITORIAL OFFICE

MDPI

St. Alban-Anlage 66

4052 Basel, Switzerland

For citation purposes, cite each article independently as indicated below:

Author 1, and Author 2. 2021. Chapter Title. In Transitioning to Quality Education. Edited by Eila Jeronen. Transitioning to Sustainability Series 4. Basel: MDPI, Page Range.

(C) 2021 by the authors. Chapters in this volume are Open Access and distributed under the Creative Commons Attribution (CC BY 4.0) license, which allows users to download, copy and build upon published articles, as long as the author and publisher are properly credited, which ensures maximum dissemination and a wider impact of our publications. 


\section{Contents}

About the Editor vii

Contributors ix

Abstracts $x i$

1 Transitioning to Quality Education: Examining Education for Sustainable 1

Development Goals, Its Limitations, and Alternatives

HELEN KOPNINA

2 High Quality Educated Teachers and High-Quality Textbooks-

The Two Pillars

of Quality Education

MARIA HOFMAN-BERGHOLM

3 Systems Thinking Research in Science and Sustainability Education:

A Theoretical Note

GÜLIZ KARAARSLAN SEMIZ

$4 \quad$ Finnish Subject Student Teachers' Views on Their Social Competencies at the

End of Their Educational Studies

EIJA YLI-PANULA, EILA JERONEN, SOFIA VESTERKVIST AND

PEKKA TOLONEN

5 Start for Sustainable Development: Ecological Footprint

89

HAMDI KARAKAŞ

6 Possibilities of Popularizing a Philosophy Course in High Schools:

The Case of Croatia

MARTINA MATIŠIĆ AND KRISTIJAN KRKAČ

7 An Argumentation Practice Based on STEAM for the Chemistry Education

of Gifted

GULSEDA EYCEYURT TURK

8 Academic Literacy Supporting Sustainability for Mathematics Education-

A Case: Collaborative Working as a Meaning Making for " $2 / 3$ "?

PÄIVI PERKKILÄ AND JORMA JOUTSENLAHTI

9 Outstanding Performance or Reversal of Fortune in Burundi's Education

System?

YASMINE BEKKOUCHE AND PHILIP VERWIMP

10 Integrating Sustainability Issues into Science Education through

Career-Based Scenarios in the MultiCO Project

TUULA KEINONEN, KATRI VARIS, COSTAS P. CONSTANTINOU, MIIA

RANNIKMÄE, ANNETTE SCHEERSOI AND SHIRLEY SIMON

About the Authors 



\section{About the Editor}

Dr. Eila Jeronen, University Research Fellow, Ph.D. (Education), Lic. Phil. (Biology), M. Sc. (Biology), University of Oulu. Eila Jeronen is adjunct professor of environmental education at University of Oulu, adjunct professor of sustainable development education at University of Helsinki, and adjunct professor of biology education at University of Lapland. Her research interests are teacher education and teaching and learning, especially in the area of natural sciences, environmental education, sustainable development education, and health education. She has published in several international journals and guided doctoral students. She has also served as a university lecturer at the Faculty of Education in the University of Oulu, Finland, and worked on international projects in several countries. eila.jeronen@oulu.fi

https://orcid.org/0000-0001-8610-2355

http://cc.oulu.fi/ ejeronen/index.html 



\section{Contributors}

\author{
ANNETTE SCHEERSOI \\ Professor, University of Bonn, Germany. \\ COSTAS P. CONSTANTINOU \\ Professor, University of Cyprus, Cyprus. \\ EIJA YLI-PANULA \\ Adjunct Professor, University of Turku, \\ Finland.
}

\section{EILA JERONEN}

Adjunct Professor, University of Oulu, Finland.

\section{GULSEDA EYCEYURT TURK}

Assistant Professor, Sivas Cumhuriyet University, Turkey.

GÜLIZ KARAARSLAN SEMIZ

Assistant Professor, Ağrı İbrahim Çeçen University, Turkey.

\section{HAMDI KARAKAŞ}

Assistant Professor, Sivas Cumhuriyet University, Turkey.

\section{HELEN KOPNINA}

Ph.D., The Hague University of Applied Science (HHS), Netherlands.

\section{JORMA JOUTSENLAHTI}

Adjunct Professor, Tampere University, Finland.

\section{KATRI VARIS}

MA, Law School of University of Eastern Finland, Finland.

KRISTIJAN KRKAČ

Professor, Zagreb School of Economics and Management, Zagreb, Croatia.

\section{MARIA HOFMAN-BERGHOLM}

Ph.L., Centria University of Applied Sciences, Finland.
MARTINA MATIŠIĆ

Professor, Business High School Varaždin and the High School in Maruševec, Croatia.

MIIA RANNIKMÄE

Professor and Head of the Centre for Science Education, University of Tartu, Estonia.

PÄIVI PERKKILÄ

Adjunct Professor, University of Jyväskylä, Finland.

PEKKA TOLONEN

Ph.D., University of Turku, Finland.

PHILIP VERWIMP

Professor, Université libre de Bruxelles, Brussels.

SOFIA VESTERKVIST

MA, Research Assistant, University of Turku, Finland.

SHIRLEY SIMON

Emeritus Professor, University College London, United Kingdom.

\section{TUULA KEINONEN}

Professor, University of Eastern Finland, Finland.

YASMINE BEKKOUCHE

Postdoctoral Research Fellow, University of Oxford, United Kingdom. 



\section{Abstracts}

\section{Development Goals, Its Limitations, and Alternatives by Helen Kopnina}

Despite the willingness of many educational institutions worldwide to embrace Education for Sustainable Development and Education for Sustainable Development Goals, critical scholars have pointed out that the very enterprise of sustainable development is not without its contradictions. Therefore, any education that engages with sustainable development needs to be carefully reviewed, rather than supported, in its ambition to promote the supposedly universally desirable aims. The rhetoric of sustainable development as meeting the needs of present and future generations is largely anthropocentric in failing to take nonhuman species into account when setting up pragmatic and ethical objectives. Similarly to the Millennium Development Goals (MDGs) that have helped to raise living standards across the world, but have largely failed to address environmental sustainability challenges, the Sustainability DevelopmentGoals(SDGs) tend to prioritize "inclusive economic growth" at the expense of ecological integrity, which is very likely to negatively affect not only nonhuman species but also future generations and their quality of life. Thus, as this chapter will argue, universally applicable Education for Sustainable Development Goals (ESDGs) is problematic in the context of addressing the long-term sustainability for both human and nonhuman inhabitants of the planet. Given escalating climate change, biodiversity loss, pollution, and depletion of natural resources, this chapter questions whether ESDGs can qualify as a desirable "quality education". The paradoxes of sustainable development and ways forward that seem a better alternative for ESDG include indigenous/traditional learning, ecopedagogy, ecocentric education, and education for degrowth, steady-state, and Cradle-to-Cradle and circular economy. Advantages of universal education are also highlighted, as any education that supports basic literacy, numeracy, and values attributed to the intrinsic rights of humans and nonhumans can help students to be equipped to deal with social and environmental challenges. 


\section{High Quality Educated Teachers and High-Quality Textbooks- The Two Pillars of Quality Education by Maria Hofman-Bergholm}

This book chapter is a theoretical discussion highlighting two important pillars of quality education. The importance of teaching material and textbooks is discussed and issues around implementation of sustainability and the Sustainable Development Goals in education. It contains research results from the Nordic countries around teacher education and early childhood education teachers, discussions on issues and obstacles and some possible solutions for a way forward.

\section{Systems Thinking Research in Science and Sustainability Education: A Theoretical Note by Güliz Karaarslan Semiz}

Systems thinking is a very important skill in both science education and sustainability education. In order to achieve sustainable development goals (SDGs), the quality of education should be increased to be able to deal with the complex problems of today, and the systems thinking skills of students and teachers should be developed. Many studies have so far investigated systems thinking skills within the science education and sustainability education context, and they have shown that systems thinking skills can be developed at different grade levels using various teaching strategies. The aim of this literature review is to examine these studies in terms of topic, research methodologies and systems thinking models. Moreover, 32 articles published in peer-reviewed scientific journals from 2009 to 2019 were selected and examined. The data were analyzed through qualitative content analysis. The results revealed that the topics that the majority of researchers focused on included sustainability problems, complex systems and earth system (especially water cycle). In the 13 articles, researchers studied systems thinking skills with lower secondary school students. Fewer studies were conducted with primary school, upper secondary school and undergraduate students. Furthermore, 17 articles included intervention studies and the most frequently used teaching strategies were inquirybased teaching and computer simulation programs. Systems thinking models used in the selected articles were also examined and discussed. This literature review provides several directions for future studies. 


\section{Finnish Subject Student Teachers' Views on Their Social Competencies at the End of Their Educational Studies by Eija Yli-Panula, Eila Jeronen, Sofia Vesterkvist and Pekka Tolonen}

In subject teacher education, the main issues in sustainable development education (SDE) lie in questions as to what the educators are supposed to teach, what the status of subject teacher education is today in embedding SDE, and how SDE relates to the focus on professional competencies in teacher education. The aim of this study is to investigate the subject student teachers' views on their social competencies in teaching students about sustainable development (SD) with respect to local, regional, and global environmental issues. The study questions were: (1) What kind of environmental problems do the students regard as core environmental problems-locally, regionally, and globally? (2) What kind of opportunities do the students feel they have to socially influence local, regional and global environmental issues? (3) How do the students identify and understand the social relationships in the classroom? and (4) How do the students see their likelihood of influencing the school culture they are working in with respect to sustainable development? A total of 142 subject student teachers at six Finnish universities were surveyed. The material was collected using a web-based questionnaire and analyzed by inductive content analyses based on two factors: (1) the multidimensional adapted process model of teaching, especially regarding teachers' social competences and (2) the competences in SDE. The results showed the students are concerned about issues such as climate change and littering, and would address these by reasonable knowledge construction and social means. In the school environment, the students are interested in SD decision-making, and they value equality and the mental wellbeing of students, which are supported by the quality of education goals, especially Sustainable Development Goal 4 (SDG4). The findings are discussed with respect to the social skills introduced in the multidimensional adapted process model of teaching, in particular with respect to the UNESCO's listed competencies in teaching and learning about SD. 


\section{Start for Sustainable Development: Ecological Footprint by Hamdi Karakaş}

The aim of this study is to investigate the relationship between elementary school students' ecological footprint mean scores and their attitudes towards sustainable development. Two hundred and ten elementary school students from three different regions of Turkey (east, middle and west) were included in the study group. As a result of the research, the mean ecological footprint scores of elementary school students were calculated as 2.11 global hectare (gha) and their ecological footprint has been determined to be lower than Turkey's mean (2.7 gha), but higher than the world mean (1.8 gha). The mean score of attitude towards sustainable development of elementary school students was calculated $(X=3.62)$, and the low mean score showed that elementary school students did not exhibit the expected sustainable development attitude. A negative correlation was determined between the mean scores of ecological footprints of elementary school students and the mean scores of sustainable development attitude and it was concluded that this relationship was significant. This result shows an inverse relationship between ecological footprint and sustainable development for elementary school students. Achieving sustainable development is primarily possible by changing the consumption habits of individuals. This can be achieved with SDG goal 4 "Quality Education". Ecological footprint awareness can be used as a tool for the students to become aware of their own consumption habits, to develop the characteristics expected from it and thus to create sustainable development by using natural resources more effectively.

\section{Possibilities of Popularizing a Philosophy Course in High Schools: The Case of Croatia by Martina Matišić and Kristijan Krkač}

In the text, the authors provide a research plan related to changes in a high school philosophy course. The mentioned description, analysis, review and suggestions are put together in the following way. 1st Part: we supply a theoretical context for a different understanding of the high-school philosophy course in gymnasiumbased educational systems. This understanding is based on the inclusion of a series of topics in popular philosophy as a philosophy of popular phenomena and the inclusion of modern teaching methods and tools, such as philosophy in comic book format or philosophy by the film. 2nd Part: we suggest some principles of 
remodeling for the high school philosophy course, based on previous descriptions of different understandings of philosophy as popular, but also with the inclusion of inter-course topics that overlap with 2 or more courses that are different to philosophy. 3rd Part: we present the results of the primary research related to high school philosophy course textbooks in Croatia in the period 1965-2019.

\section{An Argumentation Practice Based on STEAM for the Chemistry Education of Gifted by Gulseda Eyceyurt Turk}

In this study, it was aimed to enhance gifted students' argumentation skills by making them complete the missing parts of chemistry animation scenarios based on STEAM and then reconstruct them as an argument as an enrichment. The study was conducted with 12 gifted students at a school for the gifted in Ankara province in Turkey. A case study was used as one of the qualitative designs during the study. Seven different worksheets requiring the students to draw the missing part of each chemistry animation scenario and then criticize them as arguments were used as data collection tools. Content analysis was utilized for the gathered data. At the end of the study, it was found that the gifted students were able to complete the missing parts of the chemistry animation scenarios in order to construct proper concept images and then reconstruct them as arguments. It could be said that the gifted students' argumentation skills were enhanced based on their increasing success of arguing the missing parts of the chemistry animation scenarios with the help of justifying their conclusions with premises.

\section{Academic Literacy Supporting Sustainability for Mathematics Education-A Case: Collaborative Working as a Meaning Making for " $2 / 3$ "? \\ by Päivi Perkkilä and Jorma Joutsenlahti}

In this article, we focused on sustainable development in mathematics education from the point of view of academic literacy in mathematics (ALM). ALM was understood here through three integrated components: mathematical proficien-cy, mathematical practices, and mathematical discourse (languaging). ALM skills support 21st Century competences which are important for citizen 
skills. Both ALM skills and 21st Century competences support lifelong learning and sustainable education. Citizens of future society need both ALM and 21st Century competences to model and solve the issues of sustainable development. We want to develop prospective teachers' content knowledge and pedagogical con-tent knowledge of school mathematics in the spirit of sustainable education. As the case, we chose the mathematical symbol " $2 / 3$ " and how collaborative mean-ing making for " $2 / 3$ " influences prospective class teachers' interpretations. Col-laborative meaning making is part of ALM. Collaborative working as a tool for meaning making supports the other parts of ALM. By languaging different meanings for " $2 / 3$ " in pairs, prospective class teachers deepened their under-standing about fractions. By supporting ALM skills in teacher education, future class teachers can have a more sustainable basis to teach mathematics for chil-dren. As a conclusion, based on the results of our case study, we summarized objectives for sustainable development for teacher education, teachers, and stu-dents in mathematics education.

\section{Outstanding Performance or Reversal of Fortune in Burundi's Education System? by Yasmine Bekkouche and Philip Verwimp}

From the Millennium Development Goals to the Sustainable Development Goals, the focus of educational policies recommendations for the Global South has shifted from the quantity to the quality of education. The learning crisis many developing countries face is even more severe in sub-Saharan Africa and exhibits the difficulty of reforming education systems. The political economy of education seems to be a key factor in study education quality. In that regard, Burundi provides an insightful case study: its education system stands as an outlier when it comes to primary school quality and presents a strong geographical heterogeneity. We find that Burundi has experienced a sharp increase in test scores from 2009 to 2014, both in an absolute sense and relative to similar sub-Saharan African countries. We find this increase is mainly due to the performance of the Northern provinces, the region of birth of late President Nkurunziza. Turning to the mechanisms, no other hypothesis has been tested, but our difference in difference analysis reveals that the improved performance of this region cannot be explained by better infrastructure. 


\section{Integrating Sustainability Issues into Science Education through Career-Based Scenarios in the MultiCO Project by Tuula Keinonen, Katri Varis, Costas P. Constantinou, Miia Rannikmäe, Annette Scheersoi and Shirley Simon}

The MultiCO project focused on creating career-based scenarios with the intent to make science education more relevant to students and to enhance students' interest towards science studies and their awareness of scientific careers. This was undertaken through longitudinal studies involving interventions that used motivational scenarios, which were created with multi-stakeholder co-operation between scientists in education and natural sciences, experts from industry and civil society organisations, and formal, as well as non-formal science educators and students. Scenarios were defined as motivational student-relevant constructs related to an attractive issue with the possibility to involve students in an unusual scientific, hands-on activity appreciated as relevant by students, and included career-related aspects. The scenario problem, issue or situation was linked to EU challenges related to energy, water, waste, climate change, food, health, and transport issues. In this book chapter we introduce these scenarios in the light of sustainability focusing on content, context, pedagogy, and skills considered in the scenarios. In relation to Education for Sustainable Development, MultiCO scenarios incorporate both affective and cognitive aspects of learning using contexts relevant to students. The scenarios include decision-making through social learning, local or global perspectives, critical thinking and analysis, and empower students to take action on issues related to sustainability. 



\section{Transitioning to Quality Education: Examining Education for Sustainable Development Goals, Its Limitations, and Alternatives}

\section{Helen Kopnina}

\section{Introduction}

The Limits to Growth report published almost half a century ago was based on a computer simulation of exponential growth with a finite supply of resources, and it underscored concerns about human population growth and increase in consumption (Meadows et al. 1972). Heeding the report's warning and expressed need to urgently address environmental problems resulting from demographic and industrial activity increase, The Belgrade Charter, supported by The United Nations Environmental Program (UNEP) and The United Nations Educational, Scientific and Cultural Organization (UNESCO), developed educational guidelines to facilitate the transition to an environmentally sustainable society. This education was targeted towards addressing environmental problems and motivating students to better protect the environment (Orr 1994). The Belgrade Charter's initiative intended to teach students at all levels the fundamentals of ecology, simultaneously developing an awareness of the plight of the environment and motivation for protecting it through the acquisition of knowledge and practical skills to address challenges (UNEP and UNESCO 1976).

However, despite the increased severity of environmental problems since the 1970s, as the Intergovernmental Panel on Climate Change (IPCC 2019) and the Millennium Assessment Reports (MEA 2019) testify, pro-active education focused on understanding the root causes of the problems and drastic measures focused on their resolution has given way to a more optimistic belief in a balanced and integrated approach to the economic, social, and environmental dimensions of sustainable development (Leicht et al. 2018). In 1987, the World Commission on Environment and Development produced a well-known document called Our Common Future, also known as the Brundtland Report, named so in recognition of the former Norwegian Prime Minister Gro Harlem Brundtland (WCED World Commission on Environment and Development). In this document, sustainable development was referred to as "development that meets the needs of the present without compromising 
the ability of future generations to meet their own needs" (WCED World Commission on Environment and Development, p. 4).

Soon after publication of the Brundtland Report, Education for Sustainable Development (ESD) was developed. ESD commonly encourages changes in knowledge, skills, values, and attitudes to enable a more sustainable and just society, aiming to empower the present and future generations to meet their needs (Leicht et al. 2018). In its phrasing, as opposed to a more urgent tone of the Belgrade charter, the ESD has placed more emphasis on social and economic aspects of sustainability (UNESCO 2005).

Consequently, the UN Sustainability Development Goals (SDGs), following the Millennium Development Goals (MDGs), was developed. These goals built upon what was seen as great achievements of the MDGs: reducing poverty, mortality, and raising overall living standards throughout the globe. The 17 SDGs include poverty alleviation, sustainability education for achieving food security and promoting sustainable agriculture, ensuring a continuum of quality care for healthy lives and well-being, quality education, gender equality and empowerment, sustainable management of water and sanitation, access to sustainable and modern energy, sustainable economic growth, sustainable industrialization and infrastructure, sustainable cities and human settlements, conservation and sustainable use of marine and terrestrial ecosystem and resources, justice and peace, and partnerships for implementation.

Significantly, while the MDGs did achieve many social and economic goals, their record in targeting environmental problems from climate change to biodiversity loss has been seen as dismal (IPCC 2019; MEA 2019). The failure of biodiversity conservation strategies and climate change mitigation efforts are apparent as the greenhouse gas emissions have sharply increased after the publication of The Limits to Growth report (Washington 2015). It has also been noted that while the MDGs aims of eliminating extreme poverty and hunger, reducing mortality, etc., have been achieved, future social and economic security, let alone environmental integrity, can hardly be guaranteed due to increased pressure on natural resources and accelerating climate change that affects mostly poor countries (Wijkman and Rockström 2012). Critical academic researchers have stated that the overarching drivers of overshoot are the ideology of economic growth, population growth associated with increase in consumption, as well as denial of ecological limits (Rees 2010; Washington et al. 2017).

Ignoring these failures, swiftly after the publication of the SDGs, new documents supporting Education for Sustainable Development Goals, or ESDGs, were published (UNESCO 2017). The fourth goal of the SDGs, namely "Quality Education", aspires 
to enable every student to acquire the knowledge and skills needed to promote sustainable development (UNESCO 2017). This assumes that the SDGs and ESDG are a good thing.

This chapter will argue that universally applicable ESD and ESDG are problematic. Quality education does require teachers that have the competence, knowledge, and skills to be able to plan and carry out meaningful education and teaching. However, if sustainability and sustainable development are not the same, and might be at times even opposed to each other, the question is whether teaching sustainable development should be seen as something "good" in the first place. This chapter will explore the question of what is wrong with ESD/ESDG and what can be done better to encourage a more radical understanding of sustainability challenges and action to address them. The chapter will encourage critical reflection on the ideas of sustainable development, assuming that such reflection can foster greater awareness of contradictions inherent in the SDG's aims to simultaneously address social, economic, and ecological challenges through economic means. To explain what might be wrong with ESD/ESDG, the broader question will be posed: what is or should be the purpose of education?

\section{Materials and Methods}

This chapter is based on desk research examining policy documents, especially stemming from the United Nations, as well as pedagogical and critical literature on sustainable development. These materials (web pages on the Internet, journals, and books in the fields of education or pedagogical studies and critical theory, etc.) were searched using content analysis (Norris and Jacobson 1998; Elo et al. 2014). As noted by Elo et al. (2014), results of qualitative content analyses are linked to transferability, conformability, and credibility; however, it is often difficult to evaluate the trustworthiness of such analyses because of the specific data collection method used. In this case, one of the limitations was the fact that sampling of ESDG-related literature was restricted to UNESCO documents, as the initiative started just a few months before writing this chapter. While there is robust literature addressing the impact and shortcomings of ESD (for recent overview see Kopnina 2020), ESDG practices still need to generate a volume of evaluative academic publications. The section criteria used for literature selection were relevant to the central premise of this paper-identifying and analyzing the aims of ESD and the ESDG curriculum. The literature review was organized into sections that presented themes including the transition from education that heeds the Limits to Growth warning of environmental problems, to education embracing the (naïve) 
optimism of the Brundtland report, corresponding to the transition to ESD and ESDG. This literature search also identified trends in these shifts, including relevant theory connected to the critique of sustainable development, anthropocentrism, and neoliberal economy.

\section{Results: What Is or Should Be the Purpose of Education?}

The documentary film Schooling the World, directed by Carol Black (2010), reflects on the education offered to local Indian villagers as well as presents interviews with anthropologists and professionals involved in development. Black traces the idea of universal education to Christian missionaries as well as colonial powers, operating schools from Africa to Australia, with learning aimed to substitute indigenous knowledge with the supposedly superior notions of progress. In a chapter reflecting on her experience in making the movie, Black (2017, p. 453) writes:

"Just as non-Christian societies have been seen by missionaries as "heathen" rather than as having different but valid spiritual beliefs, societies that lack schools are often seen not as having different but valid modes of knowledge and learning, but as "uneducated" and "illiterate." And just as the "salvation" of Indigenous people has often historically been the companion of conquest, the "education" of Indigenous people is often an integral part of planned programs of economic development and resource extraction on Indigenous lands ... "

Helena Norberg-Hodge, author and filmmaker and the founder and director of Local Futures, reflects on an assumption that Western education and knowledge is superior, and that our "developed" nations have "evolved to a higher level of being, and that these people, however lovely they are, they're going to benefit from this superior knowledge" (Norberg-Hodge in Black 2010). This realization reflects the theory of "cognitive imperialism", describing the "process through which education is used to validate certain forms of cognition and to simultaneously devalue others that represent alternative perception and spiritual understanding which for millennia have guided human relationship to the natural world" (Battiste 1998, p. 19). In this documentary, cognitive imperialism refers to schools set up by missionaries or Western development agencies, oftentimes destroying bio-cultural diversity. While "traditional" (implying a "thing from the past") learning is seen as "backward", Western education and the desire to "get a good job" is perceived as modern and superior (Black 2010). However, from an anthropological and historical point of view, "traditional" cultures "are not failed attempts at being us-they are unique 
answers to the fundamental question, 'What does it mean to be human and alive?'” (Davis quoted in Black 2010).

The ESDGs do not provide an answer to this question. In fact, in its colonial overtones implying that Western society knows better (although its sustainability record shows otherwise), an imposition of "universal" education is also highly suspect. This leads us to the realization that a less neocolonial alternative to "education for all" should not come from the top down, but perhaps from the bottom up.

\subsection{ESD and ESDG: A Good Thing?}

As early environmental education used to emphasize human responsibility in the process of environmental destruction and called for the duty to repair the damage, with an often ecocentric (ecosystem-centered, recognizing the intrinsic value of environment) approach (Van Matre 1978; Orr 1994), ESD tends to be more focused on the balance between social, economic, and ecological needs as well as being almost exclusively anthropocentric (Bonnett 2007, 2013; Kahn 2010; Kopnina 2012, 2013a, 2013b, 2014a, 2014b, 2015a; Washington 2018). The terms "inclusive economic growth" or "sustainable use" are used abundantly in the descriptions of the SDGs (e.g., UNESCO 2017), basically presenting the environment as a resource for human use and excluding nonhuman species as stakeholders (Kopnina 2018; Kopnina and Gjerris 2015). Clearly, "inclusion" here refers to one single species (Kopnina and Cherniak 2016), as nonhuman beings and their habitats do not profit from economic growth or industrial development.

As Haydn Washington (Washington 2015; 2018) has emphasized, sustainability and sustainable development are different concepts. The term sustainable development often refers to wanting to sustain industrial and economic development (Kopnina and Meijers 2014; Washington 2018). The triple objectives (People, Profit, Planet) also tend to see "people" as separate from "profit", thus creating a double weight to counterbalance "planet". By contrast, the concept of environmental sustainability takes the "planet" as a basic necessity that supports both People and Profit (Washington 2015). The "planet" also contains billions of nonhuman species, whose survival has a very different moral imperative than "profit". Simply, species extinction is a great moral wrong (Cafaro and Primack 2014). While sustainable development rhetoric frames issues of (human) hunger, inequality, racism, sexism, etc., as normative ethical issues, it seems to leave out human responsibility for converting habitats into agricultural or urban areas and threatening biodiversity.

Critics have noted while hunger and disease in one single species deserve moral consideration, the planetary-scale discrimination against nonhuman species also 
deserves our attention. As Eileen Crist (Crist 2012, p. 149) states, "More serious than modern society's potential ability to technologically fix or muddle through problems of its own making is people's apparent willingness to live in an ecologically devastated world and to tolerate dead zones, endocrine disruptors, domestic animal torture (aka CAFOS), and unnatural weather as unavoidable concomitants of modern living".

As testified by indicators of the rapid decline of biodiversity (MEA 2019), increase in activities contributing to climate change (IPCC 2019), and shortage of natural resources, we can hardly speak of the success of policies implicated in "sustainable development" (Wijkman and Rockström 2012). Philip Alston, a UN special rapporteur on poverty and human rights, said the impacts of climate change are likely to undermine not only livelihood for millions of people (Aston does not mention billions of nonhuman beings) but also democracy and peace. Quoted in The Guardian (Carrington 2019), Alston said "Climate change threatens to undo the last 50 years of progress in development, global health, and poverty reduction".

In this context, the SDGs' focus on "sustainable industrial development" remains disconnected from a critical realization that one cannot have the cake and eat it too. Crist (2012, p. 149) reflects that "sustainability" of the current industrial system is, at least in the short term, possible. Crist reflects that the "civilization at work prospecting, expanding, and diversifying the resource base is also increasingly engaged in the parallel work of correcting the side effects of its excesses" (ibid.). This is the reason why proponents of sustainable development embrace "imminent possibilities of geoengineering, synthetic biology, genetic engineering, laboratory-made meat, and sundry adaptation projects to keep climate change under control and food on the table" (ibid., p. 149). Indeed, the "Brundtland-type definitions of sustainable development reflect highly anthropocentric and economist motives that lead to nature being seen essentially as a resource" (Bonnett 2007, p. 710). It is precisely the human needs and wants, particularly economic growth and industrial development that are immoral towards the rest of the species (Kopnina 2016a; Washington 2015). Crist (2012, p. 150) has summarized this moral issue as follows:

Human supremacy has ensconced widespread indifference toward the plight of nonhumans and their homes; it ignores and keeps itself ignorant of the question of, their reproductive rights, as individuals and as species. The dominant culture thus seems unable to grasp the moral evil of erasing wild Nature just to accommodate more and more people to live, all at once, on a planet occupied as a resource satellite. 
This implies that for sustainability education to reach further than the comfortable rhetoric of "balance" or "sustainable use", the less comfortable questions of expansion of the human population and the growing appetites need to be addressed. It is, therefore, surprising that many researchers and practitioners embrace the idea of teaching for sustainable development, ESD, and ESDG. Scholars have warned that as long as social and economic priorities are being taught at the expense of environmental awareness, sustainability remains no more than a slogan (Bonnett 2013, 2015; Fien 2010; Kahn 2010; Kopnina 2013c, 2014c; Molina-Motos 2019; Sitka-Sage et al. 2017).

To sum up, the most common application for sustainable development, as "balancing" triple objectives and the SDGs, is not only anthropocentric (Adelman 2018; Kotzé and French 2018), but also counterproductive in educating future planetary citizens. In its designation as "quality education", the ESDG might negate environmental sustainability.

\subsection{Universal Education as a Positive Force: Better Alternatives}

Not all Western education needs to be criticized off-hand as economy-centered, neocolonial, or hegemonic; some types of education can be much more so. For example, a terrorism group Boko Haram (which means "Western education is prohibited"), has been responsible for creating an educational vacuum, and promoting authoritative types of "pure Islamic education" or no education at all for girls (Vos 2019). While Islamic education embraces basic numeracy and literacy, as well as wider values and eco-ethics (Mohamed 2014), the more strict or militant "pure" education promotes intolerance towards other cultures, religions, and ways of life (Vos 2019). In a less extreme example, basic numeracy and literacy are often rudimentary in poorer countries, placing children at a disadvantage when they become adults.

In the critique of Western education one needs to be careful not to throw the baby out with the bathwater, as education can be a tool of self-reflection and development of critical ability. Some critical commentators, interviewed in the documentary Schooling the World, notably Vandana Shiva, Manish Jain, Helena Norberg-Hodge, and Wade Davis, are Western-educated themselves (Kopnina 2013a).

Additionally, the choice of education does not need to be "either-or", a combination of topics and didactic styles is possible. A combination of Western education that calls attention to the scientific understanding of sustainability challenges, such as climate change, evidence of species extinction, or pollution, and local or indigenous value transfer can result in a more holistic education combining 
"modern" insights and traditional wisdom. Below, different types of alternative education will be discussed.

\subsubsection{Critical Pedagogy, Eco-literacy, and Ecopedagogy}

A return to sustainability education or education for the environment, as embraced by the Belgrade Charter, offers an alternative for educating responsible global citizens. There are many varieties of education — starting from elementary schools and leading on to universities-that can qualify as education for the environment fostering ecological citizenship (Spannring 2019). Inspired by critical pedagogy developed by Paulo Freire's seminal text Pedagogy of the Oppressed (Freire 1986), the inter-related fields of ecopedagogy and eco-literacy were to empower disenfranchised students by taking control of their own lives in the face of oppressive power holders, and understanding of one's position within a community, through active participation and engagement. Considering neoliberal economy or rapacious capitalism, it must be noted that industrial socialism or communism (at least in theory) is still based on resource exploitation (Kopnina 2016b). While neo-Marxist in its nature, Freire's theory has wider applications as it exposes the larger scale of oppression.

In the SDG-framed society and economy-centered sustainability, the impact on the oppressed nonhuman species is forgotten. The question asked by proponents of sustainable development can be summarized as "What is the maximal number of people that the Earth can provide resources for without severely degrading those resources for future people?" (Crist 2012, p. 149). Yet, as Crist notes, if planetary-scale oppression of nonhuman species is taken into account, the real moral question should be "How many people, and at what level of consumption, can live on the Earth without turning the Earth into a human colony founded on the genocide of its nonhuman indigenes?" (Crist 2012, p. 149).

Richard Kahn (Kahn 2010) foresees ecopedagogy, critical pedagogy, and eco-literacy as unique opportunities to engage students with this kind of question. This pedagogy results not just in emancipatory learning but also in the task of realizing ethical and pragmatic aspects of what development means for billions of other species. This emancipation is inspired by civil rights liberation movements, liberating slaves, granting voting rights to women and minorities (Kahn 2010; Kopnina 2014d, 2015b).

However, as opposed to social liberation movements, environmental and animal welfare liberation movements such as Earth Liberation Front (ELF) and Animal Liberation Front (ALF) have been labeled as "radical". According to Kahn, it is not 
the radicalism of the movement that needs to be criticized but a society that indeed labels movements that defend nature as terrorist organizations. Education inspired by critical pedagogy, eco-literacy, and ecopedagogy, while not at all supporting the strategy of economic sabotage employed by ELF and ALF, draws its inspiration from ideals that drive these groups (Kahn 2010; Nocella 2007). It does so as part of a future-oriented, political and legal vision rooted in ecocentrism (Cafaro and Primack 2014) that radically opposes the globalization of ideologies such as colonialism, neo-liberal economy, and imperialism, also discussed by Black (2010; 2017). These types of education attempt to foment an understanding of the current environmental predicament as well as the motivation and tools (knowledge, skills) to actively address these challenges. Such education is founded on cultural democracy, indigenous sovereignty, human rights, and respect for all life (Anderson 2012; Black 2010, 2017; Kahn 2010). In its attempt to liberate both human and nonhuman beings and support the flourishing of all planetary citizens within the multi-species community (Spannring 2019), ecopedagogy is a far cry from ESDG. ESDG can be seen as toothless in terms of environmental protection efficacy.

Equally far from ESDG is education that takes a complex interplay and intricate entanglements between social and environmental systems as a starting point (Black 2010, 2017). Far from being "under-developed" (as the very paternalistic and colonial term "development" implies), indigenous knowledge systems have developed over centuries and involve diverse, versatile content. Distinctive patterns of interpretation are anchored in diverse but traditionally sustainable worldviews (Kahn 2010). Indigenous knowledge, with its integration of the material and spiritual domains, with interdependent culture and other forms of life, is not seen in the current education of sustainable development. In a certain sense, traditional "education for all" used to exist in all localities.

Similar to ecopedagogy is the concept of ecological literacy (sometimes known as eco-literacy), developed by David Orr (1994), which emphasizes the ability of learners to understand basic facts about the environment and ecosystem functions. Ecoliteracy involves appreciating the principles of ecological community organization and uses those principles for creating sustainable societies, for example, based on Cradle-to-Cradle principles (McDonough and Braungart 2002). These principles refer to the regenerative design of products and the entire industry by using materials as nutrients circulating in technological or organic metabolisms without harmful, toxic waste products. 


\subsubsection{Emancipation and Empowerment Education}

In part, stemming from the Pedagogy of the Oppressed (Freire 1986), another alternative is an admittedly more "Western" type of education that can be described as emancipation or empowerment education. This education is rooted in empowerment theory that explores relationships between individuals within specific social, organizational, political, and, significantly, educational environments (Freire 1986; Shor 1992). When empowerment is applied to areas concerned with sustainability or nature protection, intentional education for sustainability can be seen as an enabling process targeting student abilities or competencies such as self-determination, self-efficacy, motivation, and active engagement (Kahn 2010; Nocella 2007), which is in line with the early ideals of the Belgrade charter. In this context, empowerment education reaches beyond pure economic aspirations toward more humane-and in this way possibly truly universal-ways of being in this world.

Ethically, empowerment education promises simply to encourage learners to be independent from social or cultural impositions and restrictions. Pragmatically, this education can also encourage, indirectly but very significantly, more sustainable relation to the environment through restrictions on unwanted births. The United Nations Population Fund (UNFPA 2009, 2011, 2019) has reported the need for educational investment that empowers women and girls to engage in family planning. While smaller families have a positive correlation with reducing poverty as well as a beneficial impact on climate mitigation and natural resource depletion, reducing the population is a win-win solution to social, economic, and environmental challenges (Wijkman and Rockström 2012). While the interaction between demography, food production, and biodiversity is complex, the combination of education that focuses on teaching the importance of humans, and particularly women's rights, cannot be understated (Crist et al. 2017). As Crist (2012, p. 146) notes, an "international financial, technological, knowledge and informational campaign" is needed to "bring the full range of modern contraceptive methods, safe abortion, professional counseling, and sex and health education". This is especially true in countries where these means are most urgently needed, particularly in the developing world (Potts 2009).

Next to human rights education, animal rights (and animal welfare) education is emerging (Best 2009; Gorski 2009; Kopnina and Cherniak 2016; Kopnina and Gjerris 2015; Lu et al. 2013; Ortiz 2015; Spannring 2019). In a recently published book, Animal Rights Education, Horsthemke (2018) explores how the ethical treatment and status of animals influence pedagogy, teaching, and learning in general, through existing forms of environmental education, humane or posthumanist education, ecopedagogy, critical animal pedagogy, and critical animal studies. 


\subsubsection{Ecocentric Education}

Ecocentric education is based on eco-philosophical principles, having its foundations in land ethics, deep ecology (Barrable 2019; Glasser 2004), social ecology, ecofeminism, experiential education deep ecology (e.g., LaChapelle 1991), ethics underlying biological conservation (e.g., Norris and Jacobson 1998), and/or animal rights (e.g., Horsthemke 2018) and welfare (Kopnina 2019a; Molina-Motos 2019), post-humanism and post-colonialism (e.g., Bonnett 2013), and other types of pedagogies closely related to the ones discussed above. In a larger context, ecocentric education promises to bring the realization of moral wrongs inflicted by one species upon all others, and is also a vision of hope, as expressed by Crist (2012, p. 150):

Hope lies in humanity's coming to realize the immensity of what we are irretrievably losing, which is not resources. Hope lies in the fact that we are native to the Earth: we have the potential of understanding that we are losing our own family.

This is a far cry from the 17 SDGs that emphasize sustainable use and sustainable industrialization perpetuating an anthropocentric and profit-driven paradigm. By contrast to the ESDGs, ecocentric education fosters wonder or empathy towards nature (Nakamura et al. 2019). The issues of food security and the basic needs of human beings - and for that matter, nonhuman beings-are deemed important, as all lives matter in an ecocentric thought.

\subsubsection{Education for Alternative Economic Models}

Alternatives to neoliberal, capitalist (or industrialist socialist or communist) systems have been proposed by several critical economists and social scientists. These include the concepts of degrowth, steady-state economy, and circular economy (Daly 1991, 2014; O'Neill 2012; Washington 2015, 2018). While the scope of this chapter does not allow for a detailed discussion of these alternatives, briefly, a steady-state economy refers to an arrangement where throughput is maintained within ecological limits (Daly 1991, 2014)—something that in the context of present overproduction and overconsumption requires degrowth. O'Neill (2012) defines degrowth as the voluntary transition towards a just, participatory, and ecologically sustainable society. O'Neill (2012) proposes a framework based on ends and means, and a set of biophysical and social indicators derived from a steady-state economy, which considers the capacity of the planet to provide resources (admittedly, in this case in mostly anthropocentric framing of 'natural resources' and 'ecosystem services') and particularly variables including population and consumption 
growth. Notably, ESDG-related publications (Leicht et al. 2018; UNESCO 2017) do not mention degrowth (O'Neill 2012), steady-state economy (Daly 1991), nor Cradle-to-Cradle economy (McDonough and Braungart 2002). However, there are occasional references to the circular economy, finding reflection in the emerging education for Cradle-to-Cradle economy (https://www.c2ccertified.org/education) and education for circular economy (https://www.ellenmacarthurfoundation.org/ourwork/approach/learning).

Here, again, caution needs to be exercised as circular economy models have been often subordinated to "business-as-usual" in opportunities for future economic growth (Kopnina 2019b; Rammelt and Crisp 2014). Education for a circular economy, therefore, should not serve the purpose of education for sustaining profit that results in greenwashing, with businesses appearing green without taking sometimes drastic necessary steps to become truly 'circular' (Kopnina 2019b).

\subsubsection{Indigenous and Traditional Education}

Because the system of Western, top-down education is so different from the way local people live, so divorced from their traditional culture or harsh reality, as noted by Manish Jain (quoted in Black 2010), many local pupils end up without a diploma. This failure is based on assuming that the standard measurements of ability, or success measured by the amount of money a future job promises, do not take into consideration alternative ways of learning and being. By contrast, the conditions of learning in most indigenous societies, such as freedom, curiosity, observation, experimentation, and horizontal collaboration, may be more effective conditions for scientific learning than teacher-directed, textbook-based instruction found in most classrooms (Vedder-Weiss and Fortus 2011). Indeed, "it is likely that transmission of environmental knowledge may depend on a sibling or peer teaching, particularly during early childhood" (Zarger 2010, pp. 358-59). As the integrative and inter-dependent character of cultural and biological systems often escapes biological science, as Nabhan $(1982,2001)$ argues, indigenous knowledge that is continuous with and derived from ecosystemic awareness can offer ways forward. Nabhan (2001) notes that traditional intergenerational learning includes passing on stories and legends from old to young, stories that embody existential questions without explicit moralizing. The explicit prioritization of Western ideas over those of traditional societies is unfashionable in the post-colonial world, yet 'traditional ecological knowledge' is only considered if it contributes to corporate or industrial interests (Kidner 2017), for example, when it helps the pharmaceutical 
industry in their search for medicinal properties of rare plants. However, learning from indigenous people contains much deeper lessons that reach beyond mere utility.

\subsubsection{Basic Literacy and Numeracy Education}

In some countries in Africa or South America, the lack of basic human rights and even basic education providing basic literacy or numerical skills leads to situations where girls are taken out of schools and forced to give birth after childhood marriage or even after rape (Vos 2019; Wurth 2019). So, some basic education and policy that helps to maintain human dignity and rights—even though it can be seen as Western-can be seen as "good". One of the challenges is how to combine Western values with culturally variable ones.

Black (2017) notes that indigenous families may be making well-reasoned decisions about how to maintain their traditions while still accessing some of the positive returns of basic literacy and numeracy schooling. These basic academic skills and competencies are arithmetic, health, governance, and land rights. Such lessons can be conducted in a way that integrates existing culture and new skill development, perhaps involving parents or members of extended families not to disrupt respect for elders (Lynch and Judd 2009). It is significant though that basic numeracy and literacy education has been part of traditional education in many cultures as well.

See Table 1 (next page), which summarizes different types of alternative education.

\section{Discussion: Lessons from ESDG and Alternatives}

This chapter has argued that great caution needs to be exercised when promoting education for sustainable development and education for sustainable development goals. This caution is warranted by the underlying contradictions of the very enterprise of sustainable development that tend to prioritize social and economic objectives at the cost of environmental integrity, which, ironically, is the very foundation upon which social and economic systems are built. It was also argued that the root causes of unsustainability, population, and industrial production growth are not readily discussed in the framing of sustainable development. While the accent, both pragmatic and ethical, often lies in elevating poverty and raising living standards (which are certainly worthy objectives), the United Nations framing of sustainable development is woefully inadequate due to robust anthropocentric bias, which effectively excludes concerns about the welfare of all but one single species. 
Table 1. Alternatives to education for sustainable development and education for SDGs.

\begin{tabular}{|c|c|c|}
\hline Type of Education & Main Application & Origin \\
\hline $\begin{array}{l}\text { Critical pedagogy, eco-literacy, } \\
\text { and ecopedagogy }\end{array}$ & $\begin{array}{l}\text { Education for the environment; } \\
\text { Education for sustainability; } \\
\text { Ecocentric education; } \\
\text { Ecoliteracy; } \\
\text { Ecological citizenship }\end{array}$ & Mixed (International) \\
\hline $\begin{array}{l}\text { Emancipation and empowerment } \\
\text { education }\end{array}$ & $\begin{array}{l}\text { Education for human rights } \\
\text { (including reproductive rights, } \\
\text { family planning; sex health } \\
\text { education); } \\
\text { Education for minority rights; } \\
\text { Education for animal rights }\end{array}$ & Western \\
\hline Ecocentric education & $\begin{array}{l}\text { Deep ecology education; } \\
\text { Education stressing intrinsic } \\
\text { values; } \\
\text { Education for wonder; } \\
\text { Empathy education }\end{array}$ & Mixed \\
\hline $\begin{array}{l}\text { Education for alternative } \\
\text { economic models }\end{array}$ & $\begin{array}{l}\text { Education for degrowth; } \\
\text { Education for the steady-state } \\
\text { economy; } \\
\text { Education for Cradle-to-Cradle } \\
\text { and circular economy }\end{array}$ & Western \\
\hline $\begin{array}{l}\text { Indigenous and traditional } \\
\text { education }\end{array}$ & $\begin{array}{l}\text { Local learning exemplified by } \\
\text { ancestral forms of knowledge } \\
\text { and attitude transfer; } \\
\text { Holistic, total worldview } \\
\text { education }\end{array}$ & Traditional/indigenous \\
\hline $\begin{array}{l}\text { Basic literacy and numeracy } \\
\text { education }\end{array}$ & $\begin{array}{l}\text { Most of the existing UNESCO } \\
\text { and development } \\
\text { NGO-sponsored programs }\end{array}$ & Mixed (International) \\
\hline
\end{tabular}

Not all types of education mentioned above can or should apply in all contexts-some countries or regions might suffer from lack of basic literacy or numeracy education, but they might promote traditional values that teach the wisdom of the elders about the human relationship to the environment. "Modern" problems associated with industrial development might not be adequately addressed by any traditional education, and awareness of these issues may need to be taught. For example, in poorer countries that are most affected by plastic pollution, such as Cambodia, behavior change in the use of plastic has been rarely noted until recent educational campaigns were launched (https://plasticfreecambodia.com/; Phnom 
Penh Post 2019). A school-level program teaching about separating organic and nonorganic (e.g., plastic) garbage and using organic garbage for composting can be a starting point.

As in the case of Cambodia, school curricula in developed countries can be enriched by a more critical focus on the dominance of industry (e.g., oil producers that make petrochemical residue products, such as plastic, affordable and easily available globally) and ask students to engage with alternative thinking to sustainable packaging in line with Cradle-to-Cradle principles. While schools in developed countries may be paying lip service to sustainability, they seldom have a curriculum that encompasses human-environment interdependency as many indigenous cultures used to have (Anderson 2012).

Considering this, universally applicable education focused on the SDGs, without realizing that the goals concerned with combatting climate change, biodiversity loss, and indeed the long-term welfare of future generations are negated by continuous economic growth, is problematic. In addition, considering the discussion of neo-colonialism and bio-cultural diversity above, the appropriateness of any kind of education should be considered on a case-to-case basis.

As a counterweight to education centered on economic development, this chapter has discussed alternative forms of learning. Traditional and indigenous learning, critical pedagogy, illiteracy, ecopedagogy, ecocentric education, and alternative economy education, including education for degrowth, steady-state economy, and Cradle-to-Cradle and circular economy were discussed.

Conflicts of Interest: The author declares no conflict of interest. There were no founding sponsors who had a role in the design of the study; in the collection, analyses, or interpretation of data; in the writing of the manuscript, and in the decision to publish the results.

\section{References}

Adelman, Sam. 2018. The sustainable development goals, Anthropocentrism and Neoliberalism. In Sustainable Development Goals: Law, Theory and Implementation. Edited by Duncan French and Louis Kotzé. Northampton: Edward Elgar, pp. 15-40.

Anderson, Eugene N. 2012. Tales Best Told out of School: Traditional Life-Skills Education Meets Modern Science Education. In Anthropology of Environmental Education. Edited by Helen Kopnina. New York: Nova Science, pp. 201-11.

Barrable, Alexia. 2019. Refocusing Environmental Education in the Early Years: A Brief Introduction to a Pedagogy for Connection. Education Sciences 9: 61. [CrossRef] 
Battiste, Marie. 1998. Enabling the Autumn Seed: Toward a Decolonized Approach to Aboriginal Knowledge, Language, and Education. Canadian Journal of Native Education 22: $16-27$.

Best, Steve. 2009. The rise of critical animal studies: Putting theory into action and animal liberation into higher education. Journal for Critical Animal Studies 7: 9-52.

Black, Carol. 2010. Schooling the World: The White Man's Last Burden. Documentary film. Lost People Films. Available online: www.schoolingtheworld.org (accessed on 19 July 2019).

Black, Carol. 2017. Land-based pedagogies and the culture of schooling. In Routledge Handbook of Environmental Anthropology. Edited by Helen Kopnina and E. Shoreman-Ouimet. New York: Routledge Earthscan, pp. 452-66.

Bonnett, Michael. 2007. Environmental education and the issue of nature. Journal of Curriculum Studies 39: 707-21. [CrossRef]

Bonnett, Michael. 2013. Sustainable development, environmental education, and the significance of being in place. Curriculum Journal 24: 250-71. [CrossRef]

Bonnett, Michael. 2015. Sustainability, the Metaphysics of Mastery, and Transcendent Nature. In Sustainability: Key Issues. Edited by Helen Kopnina and E. Shoreman-Ouimet. New York: Routledge Earthscan, pp. 25-40.

Cafaro, Philip, and Richard Primack. 2014. Species extinction is a great moral wrong. Biological Conservation 170: 1-2. [CrossRef]

Carrington, Damian. 2019. 'Climate apartheid': UN expert says human rights may not survive. The Guardian. June 25. Available online: https://www.theguardian.com/ environment/2019/jun/25/climate-apartheid-united-nations-expert-says-human-rightsmay-not-survive-crisis (accessed on 19 July 2019).

Crist, Eileen. 2012. Abundant Earth and Population. In Life on the Brink: Environmentalists Confront Overpopulation. Edited by Philip Cafaro and Eileen Crist. Athens: University of Georgia Press, pp. 141-53.

Crist, Eileen, Camilo Mora, and Robert Engelman. 2017. The interaction of the human population, food production, and biodiversity protection. Science 356: 260-64. [CrossRef] [PubMed]

Daly, Herman. 1991. Steady-State Economics. Washington: Island Press.

Daly, Herman. 2014. From Uneconomic Growth to the Steady State Economy. Cheltenham: Edward Elgar.

Elo, Satu, Maria Kääriäinen, Outi Kanste, Tarja Pölkki, Kati Utriainen, and Helvi Kyngäs. 2014.

Qualitative content analysis: A focus on trustworthiness. SAGE Open 4: 2158244014522633. [CrossRef]

Fien, John. 2010. Teaching and Learning for a Sustainable Future. Paris: UNESCO. Available online: http://www.unesco.org/education/tlsf/ (accessed on 19 July 2019).

Freire, Paulo. 1986. Pedagogy of the Oppressed. New York: Continuum. 
Glasser, Harold. 2004. Learning Our Way to a Sustainable and Desirable World: Ideas Inspired by Arne Naess and Deep Ecology. In Higher Education and the Challenge of Sustainability: Problematics, Promises, and Practice. Edited by Peter Blaze Corcoran and Arjen E.J. Wals. Dordrecht: Springer, pp. 131-48.

Gorski, Paul C. 2009. Critical Ties: The Animal Rights Awakening of a Social Justice Educator. Available online: http://www.edchange.org/publications/animal-rights-social-justice.pdf (accessed on 19 July 2019).

Horsthemke, Kai. 2018. Animal Rights Education. Dordrecht: Springer.

IPCC. 2019. The Intergovernmental Panel on Climate Change reports. Available online: https://www.ipcc.ch/reports/ (accessed on 19 July 2019).

Kahn, Richard. 2010. Critical Pedagogy, Ecoliteracy, and Planetary Crisis: The Ecopedagogy Movement. New York: Peter Lang.

Kidner, David. 2017. An Anthropology of Nature-Or an industrialist Anthropology? In Routledge Handbook of Environmental Anthropology. Edited by Helen Kopnina and Eleanor Shoreman-Ouimet. New York: Routledge Earthscan, pp. 119-31.

Kopnina, Helen. 2012. Education for Sustainable Development (ESD): The turn away from 'environment' in environmental education? Environmental Education Research 18: 699-717. [CrossRef]

Kopnina, Helen. 2013a. Schooling the World: Exploring the critical course on sustainable development through an anthropological lens. International Journal of Educational Research 62: 220-28. [CrossRef]

Kopnina, Helen. 2013b. Forsaking Nature? Contesting 'Biodiversity' Through Competing Discourses of Sustainability. Journal of Education for Sustainable Development 7: 47-59. [CrossRef]

Kopnina, Helen. 2013c. Evaluating Education for Sustainable Development (ESD): Using Ecocentric and Anthropocentric Attitudes toward the Sustainable Development (EAATSD) scale. Environment, Development, and Sustainability 15: 607-23. [CrossRef]

Kopnina, Helen. 2014a. Metaphors of Nature and Economic Development: Critical education for sustainable business. Sustainability 6: 7496-513. [CrossRef]

Kopnina, Helen. 2014b. Contesting 'Environment' through the lens of sustainability: Examining Implications for Environmental Education (EE) and Education for Sustainable Development (ESD). Culture Unbound: Journal of Current Cultural Research 6: 931-47. [CrossRef]

Kopnina, Helen. 2014c. Education for Sustainable Development (ESD) as if environment really mattered. Environmental Development 12: 37-46. [CrossRef]

Kopnina, Helen. 2014d. If a Tree Falls: Business students' reflections on environmentalism. International Journal of Environment and Sustainable Development 8: 311-29. [CrossRef] 
Kopnina, Helen. 2015a. Neoliberalism, Pluralism, Environment, and Education for Sustainability: The call for radical re-orientation. Environmental Development 15: 120-30. [CrossRef]

Kopnina, Helen. 2015b. If a Tree Falls and Everybody Hears the Sound: Teaching deep ecology to business students. Journal of Education for Sustainable Development 9: 101-16. [CrossRef]

Kopnina, Helen. 2016a. Challenging economic development: The case study of teaching alternative cultural values in business education. Journal of Integrative Environmental Sciences 13: 67-84. [CrossRef]

Kopnina, Helen. 2016b. Of Big Hegemonies and Little Tigers: Ecocentrism and Environmental Justice. Special Issue "On the politics of policy-making for education for sustainable development". The Journal of Environmental Education 47: 132-50. [CrossRef]

Kopnina, Helen. 2018. Teaching Sustainable Development Goals in The Netherlands: A critical approach. Special Issue: Environmental and Sustainability Education in the BENELUX region'. Environmental Education Research 24: 1268-83. [CrossRef]

Kopnina, Helen. 2019a. Ecocentric education: Student reflections on anthropocentrismecocentrism continuum and justice. Journal of Education for Sustainable Development 13: 5-23. [CrossRef]

Kopnina, Helen. 2019b. Green-washing or best case practice? Using a circular economy and Cradle to Cradle case studies in educational practice. Journal of Cleaner Production 219: 613-23. [CrossRef]

Kopnina, Helen. 2020. Education for the Future? Critical Evaluation of Education for Sustainable Development Goals. Journal of Environmental Education in print. Available online: https://www.tandfonline.com/doi/abs/10.1080/00958964.2019.1710444? journalCode=vjee20 (accessed on 19 July 2019).

Kopnina, Helen, and Brett Cherniak. 2016. Neoliberalism and Justice in Education for Sustainable Development: A call for inclusive pluralism. Environmental Education Research 22: 827-41. [CrossRef]

Kopnina, Helen, and Mickey Gjerris. 2015. Are some animals more equal than others? Animal Rights and Deep Ecology in environmental education. Canadian Journal of Environmental Education 20: 108-23.

Kopnina, Helen, and Frans Meijers. 2014. Education for sustainable development (ESD): Exploring theoretical and practical challenges. International Journal of Sustainability in Higher Education 15: 188-207. [CrossRef]

Kotzé, Louis, and Duncan French. 2018. The Anthropocentric Ontology of International Environmental Law and the Sustainable Development Goals: Towards an Ecocentric Rule of Law in the Anthropocene. Global Journal of Comparative Law 7: 5-36. [CrossRef]

LaChapelle, Dolores. 1991. Educating for Deep Ecology. Journal of Experiential Education 14: 18-22. [CrossRef] 
Leicht, Alexander, Julia Heiss, and Won Jung Byun. 2018. Issues and Trends in Education for Sustainable Development. UNESCO. Available online: http://unesdoc.unesco.org/ images/0026/002614/261445e.pdf (accessed on 19 July 2019).

Lu, Jiaqi, Kathryn Bayne, and Jianfei Wang. 2013. Current status of animal welfare and animal rights in China. Alternatives to Laboratory Animals 41: 351-57. [CrossRef] [PubMed]

Lynch, Kelley, and Alison Judd. 2009. The School of Life: Education in a Pastoralist Community. Bristol: Taylor Brothers, Available online: http://issuu.com/kelleyslynch/docs/sol_final_ issuu/1 (accessed on 19 July 2019).

McDonough, William, and Michael Braungart. 2002. Cradle to Cradle: Remaking the Way We Make Things. New York: North Point Press.

MEA. 2019. The Millennium Assessment Reports. Available online: https://www. millenniumassessment.org/en/index.html (accessed on 19 July 2019).

Meadows, Donella H., Dennis L. Meadows, Jørgen Randers, and William W. Behrens III. 1972. The Limits to Growth. New York: Universe Books.

Mohamed, Najma. 2014. Islamic education, eco-ethics, and community. Studies in Philosophy and Education 33: 315-28. [CrossRef]

Molina-Motos, David. 2019. Ecophilosophical Principles for an Ecocentric Environmental Education. Education Sciences 9: 37. [CrossRef]

Nabhan, Gary Paul. 1982. The Desert Smells Like Rain. Tucson: University of Arizona Press.

Nabhan, Gary Paul. 2001. Cultural perceptions of ecological interactions. In On Biocultural Diversity: Linking Language, Knowledge, and the Environment. Edited by Luisa Muffy. Washington: Smithsonian Institution Press, pp. 145-46.

Nakamura, Kazuhiko W., Akio Fujiwara, Hill Hiroki Kobayashi, and Kaoru Saito. 2019. Multi-Timescale Education Program for Temporal Expansion in Ecocentric Education: Using Fixed-Point Time-Lapse Images for Phenology Observation. Education Sciences 9: 190. [CrossRef]

Nocella, Anthony J. 2007. Unmasking the animal liberation front using critical pedagogy: Seeing the ALF for who they really are. Journal for Critical Animal Studies 1: 1-10.

Norris, Kimberly S., and Susan K. Jacobson. 1998. Content analysis of tropical conservation education programs: Elements of success. The Journal of Environmental Education 30: 38-44. [CrossRef]

O'Neill, Daniel W. 2012. Measuring Progress in the Degrowth Transition to a Steady State Economy. Ecological Economics 84: 221-31. [CrossRef]

Orr, David W. 1994. Earth in Mind: On Education, Environment, and the Human Prospect. Washington: Island Press.

Ortiz, Adam. 2015. Humane Liberation: Incorporating Animal Rights into Critical Pedagogy. Connect 32: 8-30. 
Phnom Penh Post. 2019. MRC awards green campaign winners to raise awareness of plastic pollution. Cambodia Daily. Available online: https://www.cambodiadaily.com/ environment/mrc-awards-green-campaign-winners-to-raise-awareness-of-plasticpollution-147571/ (accessed on 19 July 2019).

Potts, Malcolm. 2009. Where Next? Philosophical Transactions of the Royal Society B364: 3115-24. [CrossRef] [PubMed]

Rammelt, Crelis F., and Phillip Crisp. 2014. A systems and thermodynamics perspective on technology in the circular economy. Real-World Economics Review 68: 25-40.

Rees, William. 2010. What's blocking sustainability? Human nature, cognition, and denial. Sustainability: Science, Practice, and Policy 6: 13-25. [CrossRef]

Shor, Ira. 1992. Empowering Education: Critical teaching for Social Change. Chicago: University of Chicago Press.

Sitka-Sage, Michael D., Helen Kopnina, Sean Blenkinsop, and Laura Piersol. 2017. Rewilding Education in Troubling Times; or, Getting Back to the Wrong Post-Nature. Visions for Sustainability 8: 1-19.

Spannring, Reingard. 2019. Ecological Citizenship Education and the Consumption of Animal Subjectivity. Education Sciences 9: 41. [CrossRef]

UNEP and UNESCO. 1976. The Belgrade Charter. Available online: http://www.medies.net/ _uploaded_files/TheBelgradeCharter.pdf (accessed on 19 July 2019).

UNESCO. 2005. United Nations Decade of Education for Sustainable Development (2005-2014) Framework for the International Implementation Scheme. Available online: http:// unesdoc.unesco.org/images/0013/001311/131163e.pdf (accessed on 19 July 2019).

UNESCO. 2017. Education for Sustainable Development Goals. Available online: https://www.sdg4education2030.org/education-sustainable-development-goalslearning-objectives-unesco-2017 (accessed on 19 July 2019).

UNFPA. 2009. State of World Population 2009: Facing a Changing World: Women, Population and Climate. Available online: http://www.unfpa.org/public/home/publications/pid/4353 (accessed on 19 July 2019).

UNFPA. 2011. State of World Population 2011: People and Possibilities in a World of 7 Billion. Available online: http://www.unfpa.org/public/home/publications/pid/8726 (accessed on 19 July 2019).

UNFPA. 2019. Unfinished Business: The Pursuits of Rights and Choices for All. Available online: https://www.unfpa.org/swop-2019 (accessed on 19 July 2019).

Van Matre, Steve. 1978. Sunship Earth. Martinsville: American Camping Association.

Vedder-Weiss, Dana, and David Fortus. 2011. Adolescents' Declining Motivation to Learn Science: Inevitable or Not? Journal of Research in Science Teaching 48: 199-216. [CrossRef] 
Vos, M. 2019. Hoe de politieke Islam Niger is binnengelopen. [How political Islam has snuck into Niger]. Volkskrant. May 10. Available online: https://www.volkskrant.nl/kijkverder/v/ 2019/islamisering-van-afrika-hoe-de-politieke-islam-niger-is-binnengeslopen/ (accessed on 19 July 2019).

Washington, Haydn. 2015. Is 'sustainability' the same as 'sustainable development'? In Sustainability: Key Issues. Edited by H. Kopnina and E. Shoreman-Ouimet. New York: Routledge, pp. 359-76.

Washington, Haydn. 2018. Education for Wonder. Education Sciences 8: 125. [CrossRef]

Washington, Haydn, Bron Taylor, Helen Kopnina, Paul Cryer, and John J. Piccolo. 2017. Why ecocentrism is the key pathway to sustainability. Ecological Citizen 1: 32-41.

WCED (World Commission on Environment and Development). 1987. Our Common Future. Oxford: Oxford University Press.

Wijkman, Anders, and Johan Rockström. 2012. Bankrupting Nature: Denying Our Planetary Boundaries. New York: Routledge.

Wurth, Margaret. 2019. No Girl Should be Forced into Motherhood After Rape. Human Rights Watch. May 30. Available online: https://www.hrw.org/news/2019/05/30/no-girl-shouldbe-forced-motherhood-after-rape (accessed on 19 July 2019).

Zarger, Rebecca K. 2010. Learning the Environment. In The Anthropology of Learning in Childhood. Edited by David Lancy, John Bock and Suzanne Gaskins. Lanham: Alta Mira.

(C) 2021 by the author. Licensee MDPI, Basel, Switzerland. This article is an open access article distributed under the terms and conditions of the Creative Commons Attribution (CC BY) license (http://creativecommons.org/licenses/by/4.0/). 


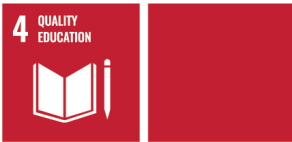

\title{
High Quality Educated Teachers and High-Quality Textbooks-The Two Pillars of Quality Education
}

\author{
Maria Hofman-Bergholm
}

\section{Introduction}

In 2015, 193 countries committed to achieving the UN's 17 Sustainable Development Goals (SDGs), a shared vision of humanity that provides the missing piece of the globalisation puzzle. The extent to which that vision becomes a reality will depend on today's classrooms; and it is educators who hold the key to ensuring that the SDGs become a real social contract with citizens. (OECD 2018, p. 2)

In the 2030 Agenda for Sustainable Development (UN 2015), the United Nations (UN) launched a set of 17 Sustainable Development Goals (SDG) to be achieved during a 15-year period. All these goals relate to education in different ways, and once again, education is set in a key position to solve all kind of problems that society faces today. The OECD even take it a step further, claiming that it is the educators in the classrooms who hold the key (OECD 2018). The SDGs build on the former millennium development goals to end poverty, inequality and climate change with one big difference- - the Agenda 2030 and the SDGs are universal, not only focusing on poor countries (Owens 2017).

The SDG 4, which is the focus of this publication, states that we need an education that "ensure inclusive and quality education for all and promote lifelong learning" (UN 2015). In a recent report, UNESCO states that it appears unlikely that the targets within SDG 4 will be met, and that there is a risk that it will not be meaningful for everyone, as it is a universal agenda, and it is unclear how different countries perceive its relevance (UNESCO 2019). This is a major weakness of the 2030 Agenda for Sustainable Development. What is of great importance and what we need to bear in mind is to recognize the different conditions that different countries have for fulfilling such universal agendas when arguing about ways of implementing the SDG 4 and its targets. We must remember and recognize the difference between north and south; east and west; rich and poor, even though the lines are not as apparent now as they were 20 years ago (Rosling et al. 2018). Unfortunately, there is an imminent risk 
that climate change affecting the world right now will increase poverty again and increase the gap between poor and rich (IPCC 2018).

Some of the targets within SDG 4 relate more to poor countries, while other targets within the goal relate to rich countries. Some of the targets relate both to poor and rich countries, for instance, human rights and appreciation of cultural diversity are targets within SDG4 that almost every country in the world, rich or poor, have problems to fulfill in different ways. In the rich countries, cultural diversity is not always appreciated, and there are issues about how governments treat aboriginal people and their rights, while in poor countries there are different angles of the problem in fulfilling human rights. The concept of lifelong learning also has a different emphasis depending on the education and income levels of the nations, and if the nation is a democracy or a dictatorship. For instance, the apartheid in South Africa has resulted in now adult people who have had little or no education. Here, lifelong learning and literacy from an adult perspective is important (McKay 2018), while this is hardly a problem in the Nordic countries.

In the Nordic countries, SDG 4 and, for instance, target 4.7 (the target is: "By 2030, ensure that all learners acquire the knowledge and skills needed to promote sustainable development, including, among others, through education for sustainable development and sustainable lifestyles, human rights, gender equality, promotion of a culture of peace and non-violence, global citizenship and appreciation of cultural diversity and of culture's contribution to sustainable development" (UNESCO 2019, p. 3) tend to be a bit problematic to fulfill within 2030, regarding education for sustainable development and sustainable lifestyles, as there is still no consensus among academics about the concept of sustainable development and which competences it involves (Hofman-Bergholm 2018a; Sinakou et al. 2018; Brandt et al. 2019). The result of this is that sustainability seems to be ignored by a large part of teacher education institutions, at least in Nordic countries (Wolff et al. 2017; Palmberg et al. 2017; Hofman-Bergholm 2018b; Hofman 2012; Borg Carola et al. 2014), which might have serious consequences throughout the whole education system, from early childhood education to teacher training programs. This is problematic, as sustainability and the development of sustainable lifestyles are targets within the SDG 4 "quality education for all" and OECD (2018) point out that educators hold the key to sustainability.

This book chapter is outlined as a theoretical discussion around the issues for implementing sustainability in education, from early childhood education to higher education, starting from a lifelong learning perspective. 


\section{Sustainability Issues in Quality Education and Lifelong Learning}

Traditionally, the term 'lifelong learning' is often attributed to adult education, but lifelong learning begins at birth, and should therefore also include early childhood education (Pramling Samuelsson and Park 2017). As Pramling Samuelsson and Park (2017) state, a lot of researchers seem to agree on the fact that a sustainable future depends on how the next generation is educated. They argue about the importance of high-quality early education and the enduring benefits from learning experience during early childhood education. It is not children's age that determine where they stand in their individual development; it is the culture they live in and prior experiences (Pramling Samuelsson 2011). Pramling Samuelsson (2011) summarize research from different kind of studies and conclude that children's attitudes and interests are developed during quite early age. That is why it is highly important to start educating children about sustainability at an early age (Pramling Samuelsson and Park 2017). Seen from this perspective, lifelong learning is the base for quality education, and it highlights the importance of an early beginning with Education for Sustainable Development (ESD).

To implement sustainability in education, it is not only policies and steering documents that are important, the executive level is equally important. Educating teachers who are teaching in early childhood education about sustainability issues should be as important as the development of curriculum plans that include sustainability (Pramling Samuelsson and Park 2017). The fact is that, for instance, in Finland, there is a gap between vision and the implementation of sustainability in early childhood teacher education (Furu et al. 2018).

Wolff and Furu (2018) have investigated how Finnish student teachers in early childhood education understand the concept of sustainable development. The research (ibid) show that the student teachers in early childhood education in Finland possesses a limited understanding of the sustainability concept, and likewise graduated teachers (Wolff et al. 2017), and even teacher educators in Finland (Hofman 2012). In another article, Furu et al. (2018) take it as far as to state that sustainability has such an inconspicuous position in the Finnish early childhood teacher education that it can be called insufficient. The same problem also seems to be common in other levels of education in Finland and other Nordic countries, all the way from the base to the top in the educational system, even though the education in the Nordic countries is considered to be high quality education.

Research shows that sustainability is integrated into Finnish schools' practices in different ways, and more or less frequently (Wolff et al. 2017). An external evaluation (Pathan et al. 2012) carried out on behalf of the Finnish Ministry of Education and 
Ministry of the Environment in 2012 revealed that only 35\% of the 917 primary and secondary schools participating in the questionnaire had programs for sustainable development. This is despite the political request for sustainable development programs in every school. In a recent article (Wolff et al. 2017), teacher training in the Nordic countries is discussed, especially teacher training in Finland. The article identifies five issues as to why an exceptionally good education, as the Finnish teacher education is according to the PISA results, does not successfully integrate sustainability into the education. These issues will be discussed in the next paragraph.

One reason why Finnish teacher education is seen as a high-performance education, producing high educated and well-trained teachers that help students perform well in the Programme for International Student Assessment of OECD (PISA tests), can be found in what the PISA tests measure. Until now, the PISA tests have focused on quite easy measurable competences, such as mathematics and reading, which has been focus in the Finnish educational system for a long time, but this changed in the last PISA test 2018, where more focus was on global competences, according to OECD:

Goal 4, which commits to quality education for all, is intentionally not limited to foundation knowledge and skills such as literacy, mathematics and science, but places strong emphasis on learning to live together sustainably. But such goals are only meaningful if they become visible. This has inspired the OECD Programme for International Student Assessment (PISA), the global yardstick for educational success, to include global competence in its metrics for quality, equity and effectiveness in education. PISA will assess global competence for the first time ever in 2018. (OECD 2018, p. 2)

Results of this PISA round 2018 will be released on 3 December 2019, so it is still uncertain as to how the Finnish students scored this time. It is an important step forward that the OECD seems to have realized that the PISA measures regulate what schools put focus on and through bringing in focus on the SDGs in PISA tests as well as other measurable competences forces the educational systems to adapt to the SDGs. This is, first and foremost, probably a very important step towards the implementation of ESD in every school.

As Finnish students performed very well in the PISA test 2000, researchers turned their eyes towards Finland to try to understand what they had done to achieve this. Finland is known to have had a very good education system since the 1968 education reform act took place and a systemwide reform of the Finnish 
educational system was carried through to be a fully comprehensive system during the 1970s. This is probably the base for the good results achieved in the 1990s. During this period, Finland also had a system with central approval of textbooks used in the school system. Finland is also one of the countries where a very high rate of teachers report that they use textbooks as a base for instructions. What might illuminate the Finnish high PISA scores in 2000 is the fact that Finnish teachers have a deep-seated tradition of using textbooks in their teaching, and that the textbooks were reviewed and approved central during a critical period of development of the Finnish educational system (Oates 2014).

According to UNESCO (2016), textbooks are recognised as core for the new SDG on education, and the amount a country spends on learning resources is a good measure of its willingness to provide all students with quality education. Access to appropriate learning materials is listed as a key strategy for achieving the first means of SDG 4. Textbooks are especially important in countries with low incomes, large classes, many unauthorized teachers and insufficient teaching time. "Next to an engaged and prepared teacher, well-designed textbooks in sufficient quantities are the most effective way to improve instruction and learning." (UNESCO 2016, p. 1).

Steiner (2017) summarizes what research says about teaching materials. He highlights that teaching materials are a decisive factor for students to successfully complete school, and that teaching materials with context and deep content are used in all high-performing school systems. Steiner's (2017) conclusion is that teaching material is very important. The English school curriculum expert Tim Oats also highlights the role of high-quality textbooks, especially during the improvement of school systems, but also the supportive role that high quality textbooks have on high quality teaching and learning (Oates 2014).

In the 1990s, the central approval of textbooks in the Finnish school system ended, but teachers still use textbooks to a great extent (Oates 2014). Textbooks are produced by teacher educators and researchers, but the question is if the now not central approved textbooks still are of such high quality and supports the national curriculum and policy documents, as in the 1990s. The results from the latest PISA investigation will be very interesting regarding global competences and SDG 4 . How did the Finnish pupils perform in this area? Moreover, an important question that needs to be the object of further research is: If textbooks are this important, do the textbooks used by teachers in Finland cover the sustainability issues and targets within the SDGs? 


\section{So, Why Is Sustainability Not Implemented in Education?}

So, why is sustainability not successfully implemented in teacher education? Is it only because nations chose to focus on things that the PISA tests measure, to perform in the global competition with other countries? This might be one reason, but there are also other issues identified.

One of the key issues/problems for implementing sustainability in education in the Nordic countries seems to be the teacher's lack of knowledge and the leaders' lack of interest in the issue. This is probably due, in part, to the complexity of the concept of sustainable development (Hofman 2015; Wolff et al. 2017). This complexity is the reason why sustainability education is characterized by a holistic approach (Boeve-de Pauw et al. 2015). According to research (Boeve-de Pauw et al. 2015; Uitto and Saloranta 2017; Borg Carola et al. 2014), school teachers, both in Sweden and Finland, are not able to adapt this important holistic view of education for sustainability, due to their own lack of a holistic understanding of sustainable development as a concept (Hofman 2012; Borg Carola et al. 2014). Borg Carola et al. (2014), Hofman (2012) and Wolff et al. (2017) state that there is a problem within teacher education, when it is not able to develop the holistic thinking needed for understanding the sustainability concept. Here is a main obstacle for implementing sustainability in the educational system; student teachers learn how and what to teach through teacher education, but as Goodwin, Smith, Souto-Manning, Cheruvu, Ying Tan, Reed and Taveras (Goodwin et al. 2014, p. 284) point out, "teacher educators cannot teach what they do not know". It all goes back to teacher education and the teacher educators-if newly qualified teachers do not know how to teach about sustainability, then there is an issue within teacher education.

Wolff et al. (2017) found these reasons for ignoring the sustainability in the Finnish teacher education: sustainability is in conflict with overall trends in society and politics; teacher education takes place at universities and is based on separate academic disciplines. Sustainability is also intricate because it is strongly connected to ecological literacy, and it is value dependent. Universities need to overcome these obstacles and become forerunners in the sustainability process (ibid.). Ignoring sustainability in teacher education will not lead to the achievement of the 17 SDGs.

As mentioned earlier, Finland is well known internationally for its highperformance education according to the PISA tests. One contributing cause of Finland's high PISA results in 2000 is probably the very competent and highly educated teachers who teach in Finnish schools. This is a result of the high-quality teacher education in Finland, where teacher education has been provided as university education since the 1970s (Wolff et al. 2017). Teacher education in Finland is a very 
popular first-hand choice for new students, and the teacher education institutions can choose top students to their education. The teacher education for both primary and secondary school teachers leads to a higher academic degree, indicating that the Finnish teachers are very well educated. However, according to Wolff et al. (2017), this does not mean that Finnish teachers are prepared to teach about sustainability issues, as sustainability seems to play a minor role in Finnish teacher education. This is possible because Finnish universities are autonomous, and can decide the content in their educational programs.

The fact that Wolff et al. (2017) state that graduated teachers do not know how to teach about sustainability makes it quite remarkable thataccording to the decree on national goals of education and the Basic Education Act, sustainable development is included in basic education in Finland. It feels provocative that Finnish teachers are not taught how to teach about sustainability, even though it is actually written in Finnish law, and highlighted already in the Finnish core curriculum 1994. The Finnish core curriculum from 1994 (Finnish National Board of Education 1994) states that biodiversity, equality, democracy, human rights and cultural diversity build the main values which touch the targets in SDG 4 to a great extent, and in the core curriculum from 2004 (Finnish National Board of Education 2004), and in the current version from 2014 (Finnish National Board of Education 2014), the importance of sustainability is even more outlined. However, at the same time, it is obvious that educators have more policy documents than the core curriculum to follow (Wolff et al. 2017), and a lack of time and knowledge is often stated as a cause that the teachers do not teach about sustainability (Borg Carola et al. 2014; Hermans 2016).

\section{We Need to Change the Way We Think and Act-But How?}

To achieve a high-quality education that includes sustainability, research indicates that change is needed in both early childhood teacher education and teacher education. In 2017, UNESCO pointed out the need for a new way of thinking:

Sustainable development cannot be achieved by technological solutions, political regulation or financial instruments alone. We need to change the way we think and act. This requires quality education and learning for sustainable development at all levels and in all social contexts. (UNESCO 2017)

One of the five identified obstacles for implementing sustainability in teacher education was that sustainability is intricate, because it is strongly connected to ecological literacy (Wolff et al. 2017). Research indicates that an ecological illiteracy 
has developed during the past few decades (Palmberg et al. 2017). Our planet suffers from air pollution, biodiversity loss, deforestation and other problems (Wolff et al. 2017), due to our continued unsustainable way of living and a major environmental threat, which has now been given more attention by Greta Thunberg's climate actions in 2019, is climate change (ibid.), which is interconnected with consumption (Ivanova et al. 2016), and thus a part of the unsustainable system. However, how can the mindset of humans be changed?

Market forces that now control the system in most of the world glorify consumerism as a requirement to achieving happiness, and society members are convinced by market forces that development and happiness are dependent on economic growth (Salonen and Konkka 2015). However, there are indications that our consumerism instead of making us happy is driving us toward illness and alienation from the social relations that increase our wellbeing (ibid.). Studies across countries show that increases in income per capita and levels of happiness do not correlate to any great extent (Salonen and Konkka 2015; Andersson and Eriksson 2010), and it now appears that values other than economic, for example living with (social relations) and for other people (doing things for others), are more important to human wellbeing than economic growth (Helliwell 2014). This is an indication that our unsustainable lifestyles and consumption do not even give us the benefits we think they do, and calls for a new way of thinking (Hofman-Bergholm 2018a).

Today, consumerism is the main focus of almost all societies over the world and world politics focuses on economic growth (Assadourian 2013; Bauman 2007; Salonen and Konkka 2015) except one, Bhutan, where Bhutan's Fourth King Jigme Singye Wangchuck already in the early 70s indicated: "Gross National Happiness is more important than Gross National Product (GNP)" (Freeman 2005, p. 1).

Bhutan's development policy, Gross National Happiness (GNH), represents an alternative policy for economic growth instead of focusing on gross national product (GNP). The GNH development policy includes the conservation of environment and equitable socio-economic development. Bhutan focus on sustainable development in their education, through values in the education and the pedagogical practices. A study (Ahonen et al. 2018) of Bhutan's secondary school students' views about their countries GNH policy concludes that the GNH development policy and the quite recently initiated GNH value education has succeeded. Bhutan has also developed a GNH teacher training, which is successful in the implementation of GNH in their school system. This needs to be shared globally to promote sustainable development education (ibid.). 
Mankind needs alternative plans for the future, for the safe existence of the planet and for an economic growth and it should all be based on systems thinking (Bunge 2000; Sterling 2009; Ahonen et al. 2018). UNESCO calls for a change in how we think and act, but how do we manage this change? UNESCO places education in a key position to enable this change, but so far, the desired results have not been achieved, even though ESD has been on the agenda for more than a decade (Hofman-Bergholm 2018a). Perhaps ESD is not enough; there is probably something still lacking that is crucial for an overall change to begin. Hofman-Bergholm (2018a) found common denominators in the nature of ESD and systems education through a literature review, and argue that there are indications that ESD and systems education could benefit from each other. Systems education and ESD could obviously constitute an interlinked common ground for sustainability education throughout the world, instead of being bounded from each other. This new learning approach with systems thinking linked to ESD could emphasize the development of different levels of systems' understanding, such as learning how to work in transdisciplinary teams, teaching basic ecological key concepts which is necessary for a holistic understanding of the sustainability concept and promoting value discussions, deliberation and action competence (Hofman-Bergholm 2018a).

Palmberg et al. (2017) and Hofman-Bergholm (2018a) argue that systems thinking can be a part of this new kind of thinking UNESCO is asking for. There is an increasing recognition that there are strong links existing between systems approaches and the sustainability goals (Cavana and Forgie 2018). Systems education helps people understand that their individual actions and choices contribute to an interconnected system, determining both the well-being of humans and the planet (ibid.). Therefore, systems thinking and systems education need to be incorporated in the education of teachers, because there is a necessity to develop an educational programme that provides individuals with knowledge about how different actions and choices affect the whole society (Palmberg et al. 2017; Hofman 2015; Hofman-Bergholm 2018a). Systems education can help transition towards a sustainable planet (Cavana and Forgie 2018).

Pramling Samuelsson (2011) highlights the '7Rs' as one way of thinking about a pedagogy for ESD in early childhood education; these Rs stand for: respect, reflect, reduce, reuse, repair, recycle and responsibility. These Rs both could and should serve as a base for all kind of education throughout the educational systems. These Rs should be the leading words for all activity and tasks in a lifelong education, from birth to death. 
To overcome the obstacles found in teacher education for implementing sustainability, writing new agendas, policy documents and new curriculums is not enough. (Hofman 2012; Hofman 2015; Wolff et al. 2017; Hofman-Bergholm 2018a; Hofman-Bergholm 2018b). It appears as the development of systematic and holistic competences are dependent on repetition during the entire education of future teachers-occasional courses are not enough (Brandt et al. 2019). A reorganization of teacher education to address sustainability and systems thinking is probably necessary to educate student teachers in these issues (Hofman-Bergholm 2018a, 2018b). It would be of great importance that all teacher students develop a system thinking perspective, so the newly qualified teachers and early childhood education teachers learn how to teach systems thinking skills to children for a sustainable future. Teacher education programmes should therefore include such a form of systems thinking that is based on critical thinking, deliberation and action competence and use the '7Rs' to promote the understanding of the sustainability concept in the study programs for teachers and early childhood education teachers. Sustainability cannot be taught without involving systems thinking (Palmberg et al. 2017).

However, to reorganize and change the whole system of teacher education is time-consuming, and adding some compulsory courses on the concepts of sustainability, ecological principles and systems thinking for all teacher students could serve as a stopgap (Hofman-Bergholm 2018a), but in the long run, a reorganization of teacher education institutions toward a systems and action approach to solve complex sustainability problems will be necessary (Hofman-Bergholm 2018a, 2018b; Brandt et al. 2019). In a recent article, Hofman-Bergholm (2018a) put forward some suggestions and recommendations around what and how to reorganize teacher education institutions.

\section{Textbooks and Teacher Education-Something Worth Investing in for All Countries}

To achieve SDG 4, there is still a lot to do for every nation worldwide. Moreover, what we need to bear in mind is the different starting point that every nation needs to fulfil the goal and its targets. The difference between global south and north needs to be taken in to account, as developing and developed countries need different perspectives and strategies to reach SDG 4. Perhaps some of the targets within the goal need to be left unfulfilled in some countries, to put focus on the most basic parts to be fulfilled. In poor countries, the focus should be on developing quality education and quality early childhood education and adult education for everyone, both boys and girls, black and white. In richer countries which are already considered 
to have developed a high-quality education, the focus needs to be on the educators, in teacher education, general education and early childhood education, to develop their understanding of how and what to teach for a sustainable future, as researchers seem to agree on the fact that a sustainable future depends on how the next generation is educated.

The most important goal should be to reach consensus on the concept of sustainability. Teacher educators need to be educated in sustainability to be able to educate student teachers, and teacher education institutions need to be re-organized to include sustainability in every part of education. In-service teachers need to be educated and to help in-service teachers in their work; there need to be high quality textbooks available with high quality content regarding sustainability (from systems thinking and how your choice affect society to climate change and how we affect nature and climate).

The importance of textbooks has also been lifted forward in this chapter. Research shows that textbooks and teaching materials count and affect teaching, and this is why it is highly important that it supports the curriculum content. This means that who writes the teaching materials and chooses the content of the textbooks is fairly important. One can even ask if teaching materials should be state approved to assure the support of the curriculum, as it seems to be a focal point of quality in teaching.

The availability of textbooks of high quality, and with a content that supports the teachers' work in implementing the curriculum content and objectives in their teaching, is a very important corner stone for the education, both in rich and poor countries.

So, how can we achieve an education that "ensure inclusive and quality education for all and promote lifelong learning" as the SDG 4 states (UN 2015)? Transformation and change, in a quite urgent manner, are needed at all levels of education, and in all societies. We now must open our eyes and look around to find the alternative plans for the future, and the general education in Bhutan could provide an example of an education that has successfully implemented ESD in its system.

Funding: This research received no external funding.

Conflicts of Interest: The author declares no conflict of interest.

\section{References}

Ahonen, Päivi Anneli, Eila Jeronen, and Riitta-Liisa Korkeamäki. 2018. How to Live Happy and Good Life? Secondary School Students' Views about Bhutan's Gross National Happiness Policy. International Journal of Environmental \& Science Education 9: 703-18. 
Andersson, Jan Otto, and Ralf Eriksson. 2010. Elements of Ecological Economics. New York: Routledge.

Assadourian, Erik. 2013. Re-engineering cultures to create a sustainable civilization. In State of the World 2013: Is Sustainability Still Possible? World watch Institute. Washington: Island Press, pp. 113-25.

Bauman, Zygmunt. 2007. Consuming Life. Cambridge: Polity Press.

Boeve-de Pauw, Jelle, Niklas Gericke, Daniel Olsson, and Teresa Berglund. 2015. The effectiveness of education for sustainable development. Sustainability 7: 15693-717. [CrossRef]

Borg Carola, Niklas Gericke, Hans-Olof Höglund, and Eva Bergman. 2014. Subject- and experience-based differences in teachers' conceptual understanding of sustainable development. Environmental Education Research 20: 526-51. [CrossRef]

Brandt, Jan-Ole, Lina Bürgener, Matthias Barth, and Aaron Redman. 2019. Becoming a competent teacher in education for sustainable development. International Journal of Sustainability in Higher Education 20: 630-53. [CrossRef]

Bunge, Mario. 2000. Systemism: The alternative to individualism and holism. Journal of Socio-Economics 29: 147-57. [CrossRef]

Cavana, Robert Y., and Vicky E. Forgie. 2018. Overview and Insights from 'Systems Education for a Sustainable Planet'. Systems 6: 5. [CrossRef]

Finnish National Board of Education. 1994. Grunderna för grundskolans läroplan [National Core Currriculum for Basic Education]. Helsinki: National Board of Education. (In Swedish)

Finnish National Board of Education. 2004. National Core Curriculum for Basic Education. Helsinki: National Board of Education.

Finnish National Board of Education. 2014. National Core Curriculum for Basic Education. Helsinki: National Board of Education.

Freeman, Myra A. 2005. Opening Address in Rethinking Development. Paper presented at Second International Conference on Gross National Happiness, Antigonish, NS, Canada, June 20-24; Centre for Bhutan Studies: Thimphu, Bhutan.

Furu, Ann-Christin, Lili-Ann Wolff, and Suomela Liisa. 2018. Premisser för hållbarhet i den finländska utbildningen av lärare inom småbarnspedagogik. En kritisk granskning av visioner och verklighet. Utbildning E Demokrati 2: 59-80. (In Swedish).

Goodwin, Lin A., Laura Smith, Mariana Souto-Manning, Ranita Cheruvu, Mei Ying Tan, Rebecca Reed, and Lauren Taveras. 2014. What should teacher educators know and be able to do? Perspectives from practicing teacher educators. Journal of Teacher Education 65: 284-302. [CrossRef]

Helliwell, John F. 2014. Social norms, happiness, and the environment: Closing the circle. Sustainability: Science, Practice and Policy 10: 78-84. [CrossRef]

Hermans, Mikaela. 2016. Från förståelse till agerande. [From understanding to action]. Turku: Diss. Åbo Akademi University. (In Swedish) 
Hofman, Maria. 2012. Hållbar Utveckling i den Finländska Lärarutbildningen-Politisk Retorik Eller Verklighet? [Sustainable Development in the Finnish Teacher Education-Political Rhetoric or Reality?]. Research Report 34. Vaasa: Faculty of Education, Åbo Akademi University. (In Swedish)

Hofman, Maria. 2015. What is an education for sustainable development supposed to achieve-A question about what, how and why. Journal of Education for Sustainable Development 9: 213-28. [CrossRef]

Hofman-Bergholm, Maria. 2018a. Could Education for Sustainable Development Benefit from a Systems Thinking Approach? Systems 6: 43. [CrossRef]

Hofman-Bergholm, Maria. 2018b. Changes in Thoughts and Actions as Requirements for a Sustainable Future: A Review of Recent Research on the Finnish Educational System and Sustainable Development. Journal of teacher education for sustainable development 20: 19-30. [CrossRef]

IPCC. 2018. Global Warming of $1.5^{\circ} \mathrm{C}$, an IPCC Special Report on the Impacts of Global Warming of $1.5^{\circ} \mathrm{C}$ above Pre-Industrial Levels and Related Global Greenhouse Gas Emission Pathways, in the Context of Strengthening the Global Response to the Threat of Climate Change, Sustainable Development, and Efforts to Eradicate Poverty. Available online: http://www.ipcc.ch/report/sr15/ (accessed on 5 November 2019).

Ivanova, Diana, Konstantin Stadler, Kjartan Steen-Olsen, Richard Wood, Gibran Vita, Arnold Tukker, and Edgar G. Hertwich. 2016. Environmental Impact Assessment of Household Consumption. Journal of Industrial Ecology 20: 526-36. [CrossRef]

McKay, Veronica. 2018. Literacy, lifelong learning and sustainable development. Australian Journal of Adult Learning 58: 390-425.

Oates, Tim. 2014. Why Textbooks Count. Policy Paper. Cambridge: University of Cambridge, Available online: https://www.cambridgeassessment.org.uk/Images/181744why-textbooks-count-tim-oates.pdf (accessed on 6 November 2019).

OECD. 2018. Preparing our Youth for an Inclusive and Sustainable World the OECD PISA Global Competence Framework. Available online: http://www.oecd.org/pisa/aboutpisa/ Global-competency-for-an-inclusive-world.pdf (accessed on 5 November 2019).

Owens, Taya Louise. 2017. Higher education in the sustainable development goals framework. European Journal of Education 4: 414-20. [CrossRef]

Palmberg, Irmeli, Maria Hofman-Bergholm, Eila Jeronen, and Eija Yli-Panula. 2017. Systems Thinking for Understanding Sustainability? Nordic Student Teachers' Views on the Relationship between Species Identification, Biodiversity and Sustainable Development. Education Sciences 7: 72. [CrossRef] 
Pathan, Alina, Marika Bröckl, Laura Oja, Sanna Ahvenharju, and Tuomas Raivio. 2012. Kansallisten kestävää kehitystä edistävien kasvatuksen ja koulutuksen strategioiden toimeenpanon arviointi [Evaluation of the Implementation of the Strategies on Education for Sustainable Development]. Available online: https:/www.ym.fi/download/noname/ \%7B7A0AC771-670C-48B8-B7F8-8FB0B173236F\%7D/78365 (accessed on 30 October 2019). (In Finnish).

Pramling Samuelsson, Ingrid. 2011. Why We Should Begin Early with ESD: The Role of Early Childhood Education. International Journal of Early Childhood 43: 103-18. [CrossRef]

Pramling Samuelsson, Ingrid, and Eunhye Park. 2017. How to Educate Children for Sustainable Learning and for a Sustainable World. International Journal of Early Childhood 49: 273-85. [CrossRef]

Rosling, Hans, Rosling-Rönnlund Anna, and Ola Rosling. 2018. Factfulness. Tio knep som hjälper dig förstå världen. (In Swedish), available in english [Factfulness. Ten reasons we're wrong about the world-and why things are better than you think]. Stockholm: Natur och Kultur.

Salonen, Arto O., and Jyrki Konkka. 2015. An Ecosocial Approach to Well-Being: A Solution to the Wicked Problems in the Era of Anthropocene. Foro de Edución 13: 19-34. [CrossRef]

Sinakou, Eleni, Jelle Boeve-de Pauw, Maarten Goossens, and Peter Van Petegem. 2018. Academics in the field of Education for Sustainable Development: Their conceptions of sustainable development. Journal of Cleaner Production 184: 321-32. [CrossRef]

Steiner, David. 2017. Curriculum Research: What We Know and Where We Need to Go. Research report. Johns Hopkins Institute for Education, StandardsWork. Available online: https://standardswork.org/wp-content/uploads/2017/03/sw-curriculum-researchreport-fnl.pdf (accessed on 5 November 2019).

Sterling, Steven. 2009. Sustainable Education. In Science, Society and Sustainability: Education and Empowerment for an Uncertain World. Edited by Donald Gray, Laura Colucci-Gray and Elena Camino. New York: Routledge, pp. 105-18.

Uitto, Anna, and Seppo Saloranta. 2017. Subject teachers as educators for sustainability: A survey study. Education Sciences 7: 8. [CrossRef]

UNESCO. 2016. Every Child Should Have a Textbook. Global education monitoring report. Policy paper 23. Available online: https://unesdoc.unesco.org/ark:/48223/pf0000243321 (accessed on 5 November 2019).

UNESCO. 2017. Complimentary Additional Programme 37 C/5—CAP Education for Sustainable Development. Available online: https://en.unesco.org/system/files/ Education\%20for\%20Sustainable\%20Development\%20-\%20Future\%20Forward.pdf (accessed on 5 November 2019).

UNESCO. 2019. Beyond Commitments-How Countries Implement SDG4. Paris: UNESCO, Available online: https://unesdoc.unesco.org/ark:/48223/pf0000369008 (accessed on 5 November 2019). 
UN (United Nations). 2015. Transforming Our World: The 2030 Agenda for Sustainable Development. Available online: https://sustainabledevelopment.un.org/post2015/ transformingourworld/publication (accessed on 5 November 2019).

Wolff, Lili-Ann, Pia Sjöblom, Maria Hofman-Bergholm, and Irmeli Palmberg. 2017. High performance education fails in sustainability?-A Reflection on Finnish Primary Teacher Education. Education Sciences 7: 32. [CrossRef]

Wolff, Lili-Ann, and Ann-Christin Furu. 2018. Hållbarhetspedagogik för finländska barnträdgårdslärar-studenter: Från begrepp till engagemang. Pedagogisk forskning $i$ Sverige 3: 214-34. (In Swedish).

(C) 2021 by the author. Licensee MDPI, Basel, Switzerland. This article is an open access article distributed under the terms and conditions of the Creative Commons Attribution (CC BY) license (http://creativecommons.org/licenses/by/4.0/). 



\section{Systems Thinking Research in Science and Sustainability Education: A Theoretical Note}

\section{Güliz Karaarslan Semiz}

\section{Introduction}

The current global problems related to climate change, energy, environment and economic inequality are complex and systemic problems, which require systemic solutions (Capra and Luisi 2014). These problems are not only the subject of science, but also the subject of geography, philosophy, economy and history (Booth-Sweeney 2017). For a sustainable world, all these problems need to be addressed together, considering the social, economic and environmental aspects of sustainability (National Research Council (NRC) 2012). At this point, education plays a crucial role to shape individuals' knowledge, skills, and attitudes to be responsible citizens for a sustainable world. The Sustainable Development Goals (SDG) adopted at the United Nations (UN) Sustainable Development Summit emphasize that all learners should acquire the necessary knowledge and skills for sustainable development until 2030. Seventeen SDGs highlight the main themes of sustainable development, which are justice, peace, equity, and gender (Osman et al. 2017). SDG 4 underlines that all people should have equal access to education and promotes lifelong learning opportunities for all people (United Nations UN). It is important to develop teachers' capabilities and increase the quality of education to deal with the complex problems of today. Particularly for children living in low-income countries, the fragile environment should be strengthened with the necessary knowledge and skills for sustainability. It is crucial to address poverty, climate change and inequality, which are interrelated problems whose solutions are interlinked (United Nations UN). Students and teachers should see these important issues as systems that interact and affect each other (Booth-Sweeney 2017). Systems thinking is a necessary tool to understand these problems and find solutions to them (Meadows 1991).

Systems thinking is a combination of different skills and is a higher order way of thinking (Ben-Zvi-Assaraf and Orion 2005; Senge 1990). Systems thinking is related to thinking in terms of connectedness, understanding relationships, patterns and contexts (Sterling et al. 2005). According to Senge (1990), it is a discipline to understand the complex systems and the interconnections among them. Systems thinking helps 
one understand how the whole system works, the fundamental reasons behind the problems, and how to find solutions to these problems (Meadows 2008). For instance, in order to understand climate change, we first need to understand how the climate works as a system, the social, political, and environmental factors affecting climate change and the relationships among these factors (Booth-Sweeney 2017). In a similar way, a watershed ecosystem includes the dimensions of a system and the relationships among them. The interconnection among geological, ecological, atmospheric and hydrological systems is important for the sustainability of the earth system (Logan 2018). Furthermore, in order to achieve the Sustainable Development Goals, integrated, holistic and multidisciplinary approaches are required, which implies putting systems thinking into practice in education (Reynolds et al. 2018).

Systems thinking has received the increasing attention of educators in recent years and has been investigated in different disciplines such as science education (e.g., Batzri et al. 2015; Brandstadter et al. 2012; Riess and Mischo 2010), biology education (e.g., Fanta et al. 2019; Zangori and Koontz 2017), engineering education (e.g., Gero and Zach 2014), and sustainability education (e.g., Ateşkan and Lane 2018; Connell et al. 2012; Sandri 2013; Remington-Doucette et al. 2013). In these studies, different research methods, measurement tools, instructional strategies and different systems thinking models have been used. Moreover, systems thinking has been investigated in various fields of study, such as ecosystems, climate change, energy transfer, and the groundwater systems (e.g., Evagorou et al. 2009; Pan and Liu 2018; Shepardson et al. 2014).

In science education, understanding complex systems and their functions requires systems thinking (Pan and Liu 2018). National Research Council (NRC) identified science education standards and focused on the core ideas and cross cutting concepts. The NRC framework included the core ideas related to the complex structure of ecosystems and the dynamic relationships in ecosystems. The NRC framework further addressed systems thinking as a cross cutting concept of understanding systems and system models. Various studies have examined students' understandings of complex systems (Ben-Zvi-Assaraf and Orion 2005, 2010a; Jin et al. 2019; Puttick and Raymond 2018). Understanding complex systems is a challenging process. For example, climate change education is generally considered to be challenging because it includes complex structures which are difficult for students to understand (Orion and Ault 2007). First, students should understand the carbon cycle system in order to understand the impact of carbon dioxide accumulation in the atmosphere (Puttick and Raymond 2018). If students can perceive climate as 
a system, then they can gain a better insight into the connection between climate, climate change, environment and humans (Roychoudhury et al. 2017).

The systems thinking perspective is critical to understanding the interconnectedness in natural systems. In order to find solutions to sustainability problems, integration of knowledge about natural and human systems and collaboration between disciplines are needed (Remington-Doucette et al. 2013). Thus, systems thinking is regarded as a central component to achieve sustainability literacy (Nolet 2009) and the key competency that teachers should have in the field of sustainability education (UNESCO 2018). It is not easy to understand sustainability issues without a systems thinking perspective (Cloud 2005). Therefore, it is important to foster teachers' systems thinking skills so that they can create teaching strategies to enhance the systems thinking skills of their students (Lavi and Dori 2019).

In order to develop the systems thinking skills of students, different approaches and strategies have been proposed in several research studies. In a recent study, Schuler et al. 2018 designed courses to measure and improve pre-service teachers' systems thinking skills. They created a competence model and measured the four dimensions of systems thinking (declarative system knowledge, system modeling, solving problems using system models, and evaluation of system models). They revealed that pre-service teachers' systems thinking and their pedagogical content knowledge to teach systems thinking can be improved through teacher education programs.

Lavi and Dori (2019) also conducted a research study in order to foster and evaluate systems thinking skills of science and engineering pre-service and in-service teachers. They developed a method to create a common language, a shared terminology related to systems thinking for science and engineering teachers. Thus, they contributed to the literature methodologically by developing a valid and reliable rubric to assess systems thinking skills.

In another study, Brandstadter et al. (2012) examined the effectiveness of the concept mapping technique to measure students' systems thinking within the context of science education. The participants of their study were primary and secondary students and they found that computer-based concept mapping is an appropriate tool to make large scale assessments in systems thinking.

Research studies to facilitate and assess systems thinking skills in science and sustainability education have increased in recent years. It is important to examine these studies in terms of their research methodology and the systems thinking models that they used. In this way, similar and different aspects of these research studies can be explored, and the gaps in the literature can be identified to guide future studies. 


\section{Systems Thinking Models}

Systems thinking has been investigated in various contexts, and different systems thinking models have been used. To be able to find a common framework for the systems thinking research, it is important to examine these models. In this part, systems thinking models used in the science and sustainability education context were presented briefly to understand the structure of these models. These models were categorized based on the dates when they were developed.

The system dynamics and systemic reasoning models were developed in the 1990s and used in educational research. Systems dynamics in education was first reported by Forrester (1992) and refers to learning by doing to change mental models (Forrester 2007). Through a systems dynamics approach, students develop problem solving skills and learn cause-effect relationships between concepts (Forrester 1992). Systems dynamics are related to integrating real life systems into computer simulation models to explore the complex structure of the systems (Forrester 2007). Systems thinking skills include dynamic complexity, positive and negative feedback processes, stock-flow relationships, recognizing delay, understanding their impacts and identifying non-linearities (Booth-Sweeney and Sterman 2000). Stock-flow relationships, feedback loops and relationships are considered aspects of systems dynamics (Nuhoğlu 2014).

Chandler and Boutilier (1992) developed a model related to systemic reasoning that includes four aspects. The authors argued that systemic reasoning is useful to understand open dynamic systems like ecological systems. The systemic reasoning model was used in recent research studies. Hokayem and Gotwals (2016) used four aspects of systemic reasoning to design learning progression within the ecological issues context. The four aspects of systemic reasoning determined by Chandler and Boutilier (1992) are as follows:

- Systemic synthesis: If an element of a system changes, the whole system is affected.

- Systemic analysis: Defining the elements of a system and recognizing the essential and non-essential elements.

- Dynamic recycling: Understanding how recycling in a system creates sustainability.

- Circular connectivity: Recognizing the feedback loops in a system.

Richmond (1991, 1993), who is an expert on systems thinking, described that individuals with a systemic perspective can see both the forest and the trees. The author noted the gap between the nature of the current problems of the world and our understanding of them. To reduce this gap, systems thinking should be understood well. Richmond (1993) suggested a systems thinking model that 
constitutes seven aspects, which are dynamic thinking, closed loop thinking, generic thinking, structural thinking, operational thinking, continuum thinking, and scientific thinking. These seven aspects show the multidimensional nature of systems thinking and each of them should be developed for better learning (Richmond 1993).

Hmelo-Silver and Pfeffer (2004) noted that it is important to recognize complex systems like ecosystems, in order to understand the interconnectedness of the world. For example, while learning ecological systems, it is necessary to envision how individuals, populations and communities interact with each other (Hmelo-Silver et al. 2007). In general, the characteristics of complex systems are difficult to understand. There are complex interactions among the components of complex systems, and these interactions are mostly nonlinear, including positive and negative feedback loops (Ben-Zvi-Assaraf and Orion 2005; Hmelo-Silver et al. 2007). If a change occurs in the components of a complex system, the stability of the whole system can be disrupted (Roychoudhury et al. 2017). These complex systems can be understood from different perspectives, like the systems dynamics model and the structure-behaviour-function (SBF) model (Hmelo-Silver and Pfeffer 2004). The SBF model formulates the essential principles to understand complex systems and allows understanding the structural elements in a system, the components of a system, the purpose of these components, and the mechanisms that enable the functioning of these components (Hmelo-Silver and Pfeffer 2004). In science education, students experience difficulties in learning complex systems (Ben-Zvi-Assaraf and Orion 2005). For example, they mostly learn simple linear relationships and visible components of ecosystems (Hmelo-Silver et al. 2007; Hogan 2000). In order to develop students' understanding of complex systems, computer-supported and hands-on activities have been suggested as useful tools (Ben-Zvi-Assaraf and Orion 2005, 2010a; Hmelo-Silver et al. 2015).

Ben-Zvi-Assaraf and Orion (2005) studied systems thinking in the field of earth system science and developed a structural hierarchical model to determine the characteristics of systems thinking. Orion (2002) maintained that understanding the earth's subsystems and their relationship with the environment requires understanding what science is. When students develop an understanding of water systems, they can understand the important role of water systems in global ecosystems (Ben-Zvi-Assaraf and Orion 2005). The authors listed eight emergent characteristics of systems thinking within the earth science context, as follows:

- The ability to identify the components of a system and processes within the system

- The ability to identify the relationships among the system's components 
- The ability to organize the systems' components and processes within the framework of relationships

- The ability to make generalizations

- The ability to identify the dynamic relationships within the system

- The ability to understand the hidden dimensions of the system

- The ability to understand the cyclic nature of systems

- The ability to think temporally: retrospection and prediction

Ben-Zvi-Assaraf and Orion (2005) emphasized that a system thinker should first understand a system's components and interactions. In order to reduce environmental threats to earth systems, dynamic and cyclic relationships should be identified. Understanding the human impact on water cycle systems of using fertilizers and pesticides can be an example of understanding dynamic relationships. Moreover, according to the authors, there might be hidden dimensions of systems that might not be seen at the first glance. The authors, for instance, noted several questions for the water cycle system, such as "What is the cause of groundwater pollution?", "How can people be affected by that pollution?" and "How long can those chemicals stay in the rocks?". They suggested that these kinds of questions are needed to have backward- and forward-thinking skills. In other words, it is important to consider the impact of current problems on our future life.

Stave and Hopper (2007), on the other hand, suggested a model which includes a taxonomy of systems thinking. The authors developed this model based on the systems dynamics literature and the interviews with systems educators, in order to determine individuals' systems thinking levels. The authors categorized seven systems thinking components based on the levels of Bloom's taxonomy. These systems thinking components are recognizing interconnections, identifying feedback, understanding dynamic behaviour, differentiating types of variables and flows, using conceptual models, creating simulation models, and testing policies. These are the dominant systems thinking components which were derived from the literature.

Recently, Arnold and Wade (2015) compared various systems thinking definitions and determined different and common points. Then, the authors suggested a new definition for systems thinking that can be used in a variety of disciplines, focusing on the goals and elements of system thinking and the interconnections among these elements. The authors combined different elements of systems thinking, such as interconnections, feedback loops, stock and flow relationships, non-linear relationships and dynamic behavior, and stated that their systems thinking definition can be used in systems thinking research studies. 
Within the scope of sustainability education, researchers focused on various systems thinking models, and discussed systems thinking as one of the key competencies of sustainability education (e.g., Sleurs 2008; UNECE 2011; Wiek et al. 2011). Sleurs (2008) defined systems thinking as recognizing that we are a part of the global system and understanding the relationship between environment, economy and society. Riess and Mischo (2010) defined systems thinking as "the ability to recognize, describe, model and explain complex aspects of reality as systems". Based on this definition, Fanta et al. (2019) designed the heuristic competence model of systems thinking within the sustainability education context. This model included four dimensions, which are "declarative system knowledge" (knowledge of different system properties), "system modeling" (understanding complex systems by system models), "solving problems using system models", and "evaluation of system models". This model was used to create effective approaches to develop the systems thinking skills of students and teachers. Furthermore, Karaarslan-Semiz and Teksöz (2020) determined twelve systems thinking skills, in the science and sustainability education context, based on the literature. The authors described some of these skills as identifying the components of a system; hidden dimensions; interrelationships among the social, economic and environmental aspects of sustainability; time dimension; recognizing personal role in the system, and the cyclic nature of the system. In order to improve the systems thinking skills of pre-service science teachers, the authors designed an outdoor education for a sustainability course, and they explored whether that outdoor education course could develop pre-service science teachers' systems thinking skills.

Some systems thinking models within the science and sustainability education context were examined and are presented in Table 1. Although these systems thinking models have similarities and differences, they are mostly based on the early definitions of systems thinking, such as that of systems dynamics by Forrester (1992) and the systems thinking approach by Richmond (1993). The systems thinking components proposed in these models are all important and interconnected. As seen in the analyzed articles, researchers have mostly used these models to design systems thinking interventions and assess the systems thinking skills of the learners. 
Table 1. Systems thinking models derived from the literature.

\section{Systems Thinking Models}

1. Systems Dynamics Model (Forrester 1992)

2. Richmond's (1993) Systems Thinking Approach

3. Systemic Reasoning (Chandler and Boutilier 1992)

4. Structure-Behavior-Function Model (Hmelo-Silver and Pfeffer 2004).

5. A Structural Hierarchical Model of Systems Thinking (Ben-Zvi-Assaraf and Orion 2005)

6. Taxanomy of Systems Thinking (Stave and Hopper 2007)

7. Arnold and Wade's (2015) Systems Thinking Model

8. Heuristic Competence Model (Fanta et al. 2019; Schuler et al. 2018)

9. Systems Thinking as a Key Competency in Sustainability Education (Sleurs 2008; UNESCO 2018; Wiek et al. 2011)

Based on the discussion above, the author aimed to present the whole picture of systems thinking models in science and sustainability education and methodological and instructional insights related to systems thinking research. It is expected that this literature review will provide several directions for future research studies. The following research questions guided this study:

1. Which topics related to systems thinking have been studied within the context of science and sustainability education and the scope of primary, secondary and higher education?

2. Which systems thinking models have been used in systems thinking research studies?

3. Which research methods and data collection tools have been applied in systems thinking research studies?

4. What teaching strategies have been used to improve the systems thinking skills of students in primary school, secondary school and higher education levels? 


\section{Materials and Methods}

This study aims to review the recent research studies on systems thinking in science and sustainability education. A systemic review was conducted in order to find appropriate articles for reviewing. In particular, the studies conducted in the past 10 years, from 2009 to 2019, were examined. Major journals in science education and sustainability education were found. In some journals, appropriate articles for this study could not be found; therefore, they were not included in the study. A search was conducted based on the terms systems thinking, science education, education for sustainability, education for sustainable development (ESD) and sustainability education. Most of the articles were written in English. Only two of the selected articles were written in Turkish. The articles were selected in terms of the following criteria:

- Scope: international and national research

- $\quad$ Type of research: empirical studies for measuring and developing systems thinking skills

- Years: 2009-2019

- Academic research articles published in peer reviewed journals

- Language: English and Turkish

- Target: students in primary, lower and upper secondary education and higher education (including student teachers)

The articles were divided into two groups: studies with and without intervention. Articles as theoretical notes and literature reviews about systems thinking were not included in the study. Consequently, 17 journals were selected and examined. In these journals, 32 articles fulfilling the above-mentioned criteria were analyzed. The selected journals and articles are presented in Table 2. 
Table 2. Selected journals and analyzed articles.

Journals

Başkent University Journal of Education (Turkish)

Education Sciences

Educational Sciences: Theory and Practice (Turkish)

Environmental Education Research

\begin{tabular}{|c|c|}
\hline Education Sciences & (Bernier 2017; Jeronen et al. 2017) \\
\hline $\begin{array}{l}\text { Educational Sciences: Theory and Practice } \\
\text { (Turkish) }\end{array}$ & (Nuhoğlu 2014) \\
\hline Environmental Education Research & $\begin{array}{l}\text { (Golick et al. 2018; Rodriguez et al. 2014; } \\
\text { Shepardson et al. 2014) }\end{array}$ \\
\hline $\begin{array}{c}\text { Eurasian Journal of Mathematics, Science } \\
\text { and Technology Education }\end{array}$ & (Ben-Zvi-Assaraf and Orion 2009) \\
\hline Journal of Biology Education & $\begin{array}{l}\text { (Fanta et al. 2019; Jordan et al. 2014; Hokayem et al. } \\
\text { 2015; Zangori and Koontz 2017) }\end{array}$ \\
\hline $\begin{array}{l}\text { Journal of Education for Sustainable } \\
\text { Development }\end{array}$ & (Foley et al. 2017) \\
\hline Journal of Environmental Education & (Tolppanen and Aksela 2018) \\
\hline Journal of Geography in Higher Education & (Schuler et al. 2018) \\
\hline Journal of Research in Science Teaching & $\begin{array}{l}\text { (Ben-Zvi-Assaraf and Orion 2010a, 2010b; } \\
\text { Hmelo-Silver et al. 2015; Hokayem and Gotwals } \\
\text { 2016) }\end{array}$ \\
\hline Journal of Science Education Technology & (Batzri et al. 2015; Puttick and Raymond 2018) \\
\hline Journal of Sustainability Education & (Connell et al. 2012) \\
\hline International Journal of Science Education & $\begin{array}{c}\text { (Brandstadter et al. 2012; Riess and Mischo 2010; } \\
\text { Evagorou et al. 2009; Pan and Liu 2018; } \\
\text { Rosenkranzer et al. 2017) }\end{array}$ \\
\hline $\begin{array}{l}\text { International Journal of Science and } \\
\text { Mathematics Education }\end{array}$ & (Puttick and Raymond 2018) \\
\hline $\begin{array}{l}\text { International Research in Geographical and } \\
\text { Environmental Education }\end{array}$ & (Cox et al. 2019) \\
\hline $\begin{array}{l}\text { International Journal of Sustainability in } \\
\text { Higher Education }\end{array}$ & (Remington-Doucette et al. 2013) \\
\hline Research in Science Education & (Lee et al. 2019; Küçük-Doğanca and Saysel 2018) \\
\hline
\end{tabular}

\section{Articles}

(?)

Qualitative content analysis was performed to analyze the selected articles (Frankel and Wallen 2006). The articles were analyzed based on the categories of topics, systems thinking models, and research methodologies. The methodology sections of the articles were categorized in terms of sample, research design, data collection process, and instructional design (if there was an intervention). Each article was read several times by the author, and a data analysis table was constructed for 
each article. The selected articles were examined based on the above-mentioned categories. The following section presents findings of the data analysis.

\section{Results}

As stated earlier, the selected articles were analyzed based on the pre-determined categories, which are topics, systems thinking models and research methodologies. Coding tables were created for each article. Table 3 shows an example of the coding system of two articles.

Table 3. An example of the coding of the articles in terms of topic, systems thinking models and research methodologies (with and without intervention).

\begin{tabular}{ccc} 
Author and Year & Paper ID-14 & Paper ID-52 \\
Title of the article & Fanta et al. (2019) & Golick et al. (2018) \\
\hline Journal & $\begin{array}{c}\text { Fostering systems thinking in } \\
\text { student teachers of biology and } \\
\text { geography-an intervention study }\end{array}$ & $\begin{array}{c}\text { A framework for } \\
\text { pollination systems } \\
\text { thinking and conservation }\end{array}$ \\
\hline $\begin{array}{c}\text { Tournal of Biology Education } \\
\text { Topics studied in the articles }\end{array}$ & $\begin{array}{c}\text { Global problems (deforestation, soil } \\
\text { degradation, overfishing, and } \\
\text { climate change) }\end{array}$ & $\begin{array}{c}\text { Environmental Education } \\
\text { Research }\end{array}$ \\
\hline $\begin{array}{c}\text { Systems thinking models } \\
\text { Sample }\end{array}$ & $\begin{array}{c}\text { Heuristic structural competence } \\
\text { model of systems thinking }\end{array}$ & $\begin{array}{c}\text { Structure-Behaviour-Function } \\
\text { Model }\end{array}$ \\
\hline Research design & Student teachers & Undergraduate students \\
\hline Intervention (Yes or No) & $\begin{array}{c}\text { Quasi experimental intervention } \\
\text { study }\end{array}$ & Qualitative inquiry \\
\hline Data Collection Method & $\begin{array}{c}\text { Achievement test (including both } \\
\text { open ended and multiple-choice } \\
\text { questions) }\end{array}$ & $\begin{array}{c}\text { Structured interviews, open } \\
\text { ended questions and } \\
\text { prompts }\end{array}$ \\
\hline Instructional design (if there & $\begin{array}{c}\text { Simulation software programs } \\
\text { (computer-based education) }\end{array}$ & No \\
\hline
\end{tabular}

According to the content analysis results, three categories of topics framed the research studies, which are "complex systems", "sustainability issues and global problems" and "earth system science". The findings showed that the research content of $47 \%$ of the articles included sustainability issues and global problems, followed by complex systems and earth systems. 
In terms of research methodologies, both qualitative and quantitative research designs were adopted in the selected articles. Notably, $53 \%$ of the articles included intervention in order to foster students' systems thinking skills. Moreover, $47 \%$ of the articles included descriptive studies such as assessing the current level of systems thinking skills of students. Notably, systems thinking researchers mostly preferred experimental and qualitative research designs.

Moreover, the selected studies included various participant groups from primary school to undergraduate level. Lower secondary school students were found to be the most studied sample $(40 \%)$. It was observed that the number of studies conducted with primary school, upper secondary school and undergraduate students was limited. Moreover, both qualitative and quantitative data collection tools were used in the studies. In fact, systems thinking researchers mostly preferred written assessments $(40 \%)$ and interviews (28\%) to evaluate systems thinking levels of students. The authors were less likely to use quantitative measurement tools to assess systems thinking skills. Table 4 shows the analysis of the selected articles in terms of topics and research methodologies.

Lastly, systems thinking models used in the selected articles were examined. It was explored that systems thinking researchers used various systems thinking models. The most commonly used systems thinking model was the systems thinking hierarchical model developed by Ben-Zvi-Assaraf and Orion (2005). The model of understanding complex systems and emergent perspectives and the structure-behavior-function model were also used in the analyzed articles to explain complex systems. There are some similarities related to the components of systems thinking in these models. The dominant characteristics of systems thinking explored in the models were the identification of components of a system and the interconnections among these components, understanding the dynamic and cyclic relationships, identifying the feedback loops, recognizing the hidden dimensions, and exploring the impact of current practices on future practices (time dimension). All these characteristics of systems thinking have been described in systems thinking models. Table 5 summarizes the systems thinking models and the number of articles that used these models.

Instructional strategies most frequently used in the intervention studies were "inquiry-based learning", "game-based education", "problem-based learning", "computer simulation programs", "outdoor learning" and "group work". Among these instructional strategies, inquiry-based teaching and computer simulation programs were the most commonly used teaching methods to improve systems thinking skills. Moreover, researchers used different teaching strategies together. For instance, 
game-based education, computer simulation programs and inquiry-based education were applied together to foster students' systems thinking skills. Figure 1 shows the instructional strategies used in the analyzed articles.

Table 4. Analysis of the articles in terms of topics and research methods.

\begin{tabular}{|c|c|c|c|c|}
\hline & & & $\begin{array}{l}\text { Number of } \\
\text { Articles }\end{array}$ & Percentage \\
\hline \multirow{3}{*}{\multicolumn{2}{|c|}{ Topics }} & $\begin{array}{l}\text { Complex systems (ecosystems, forest } \\
\text { system, climate change and pollination) }\end{array}$ & 10 & $\% 31$ \\
\hline & & $\begin{array}{l}\text { Sustainability issues and global } \\
\text { problems (e.g., sustainable energy, } \\
\text { environmental pollution, biodiversity, } \\
\text { environmental problems) }\end{array}$ & 15 & $47 \%$ \\
\hline & & $\begin{array}{l}\text { Earth system science (water cycle, } \\
\text { carbon cycle) }\end{array}$ & 7 & $22 \%$ \\
\hline \multirow{4}{*}{\multicolumn{2}{|c|}{ Research Design }} & $\begin{array}{l}\text { Quantitative Research Design (survey } \\
\text { research) }\end{array}$ & 3 & $9 \%$ \\
\hline & & $\begin{array}{l}\text { Qualitative Research Design } \\
\text { (descriptive) }\end{array}$ & 10 & $31 \%$ \\
\hline & & $\begin{array}{l}\text { Mixed Research Design (both } \\
\text { qualitative and quantitative) }\end{array}$ & 2 & $6 \%$ \\
\hline & & $\begin{array}{l}\text { Intervention Study (experimental and } \\
\text { qualitative) }\end{array}$ & 17 & $53 \%$ \\
\hline \multicolumn{2}{|c|}{ Intervention (Yes) } & Yes & 17 & $53 \%$ \\
\hline \multicolumn{2}{|c|}{ Intervention (No) } & No & 15 & $47 \%$ \\
\hline \multirow{7}{*}{$\begin{array}{l}\text { Data } \\
\text { Collection }\end{array}$} & \multirow{5}{*}{ Qualitative tools } & $\begin{array}{l}\text { Interviews (structured, task-based, } \\
\text { interviews with scenarios) }\end{array}$ & 9 & $28 \%$ \\
\hline & & $\begin{array}{l}\text { Written assessments (open-ended } \\
\text { questions) }\end{array}$ & 13 & $40 \%$ \\
\hline & & Case study analysis & 2 & $6 \%$ \\
\hline & & Concept maps & 4 & $12 \%$ \\
\hline & & Drawings & 7 & $22 \%$ \\
\hline & \multirow{2}{*}{ Quantitative tools } & Multiple choice tests & 4 & $12 \%$ \\
\hline & & $\begin{array}{l}\text { Questionnaires (including Likert type } \\
\text { questions) }\end{array}$ & 4 & $12 \%$ \\
\hline \multirow{5}{*}{\multicolumn{2}{|c|}{ Sample }} & Primary school students & 5 & $15 \%$ \\
\hline & & Lower secondary school students & 13 & $40 \%$ \\
\hline & & Upper secondary school students & 5 & $15 \%$ \\
\hline & & Student teachers & 7 & $22 \%$ \\
\hline & & Undergraduate students & 5 & $15 \%$ \\
\hline
\end{tabular}


Table 5. Systems thinking models used in the analyzed articles.

\begin{tabular}{lcc} 
Systems Thinking Models & Number of Articles & Percentage \\
\hline $\begin{array}{l}\text { Dynamic thinking and cyclic thinking (Richmond 1991, 1993) } \\
\text { Systemic reasoning framework (Chandler and Boutilier 1992) }\end{array}$ & 1 & $3 \%$ \\
\hline $\begin{array}{l}\text { Systems Dynamics (Forrester 1992) and Systems' model of } \\
\text { Booth-Sweeney and Sterman (2000) }\end{array}$ & 4 & $3 \%$ \\
\hline $\begin{array}{l}\text { Understanding complex systems and emergent } \\
\text { perspectives-Structure-Behaviour-Function Model } \\
\text { (Hmelo-Silver and Pfeffer 2004; Hmelo-Silver et al. 2007, 2015; } \\
\text { Hogan 2000; Wilensky and Resnick 1999) }\end{array}$ & 8 & $13 \%$ \\
\hline $\begin{array}{l}\text { Systems Thinking Hierarchical Model (Ben-Zvi-Assaraf and } \\
\text { Orion 2005) }\end{array}$ & 9 & $25 \%$ \\
\hline Stave and Hopper (2007)'s systems thinking model & 1 & $28 \%$ \\
\hline $\begin{array}{l}\text { Arnold and Wade (2015)'s systems thinking model } \\
\text { Heuristic-Structural competence model (Fanta et al. 2019; } \\
\text { Schuler et al. 2018) }\end{array}$ & 1 & $3 \%$ \\
\hline $\begin{array}{l}\text { Systems thinking as a key competency for sustainability } \\
\text { education (Sleurs 2008; Wiek et al. 2011) }\end{array}$ & 3 & $3 \%$ \\
\hline
\end{tabular}

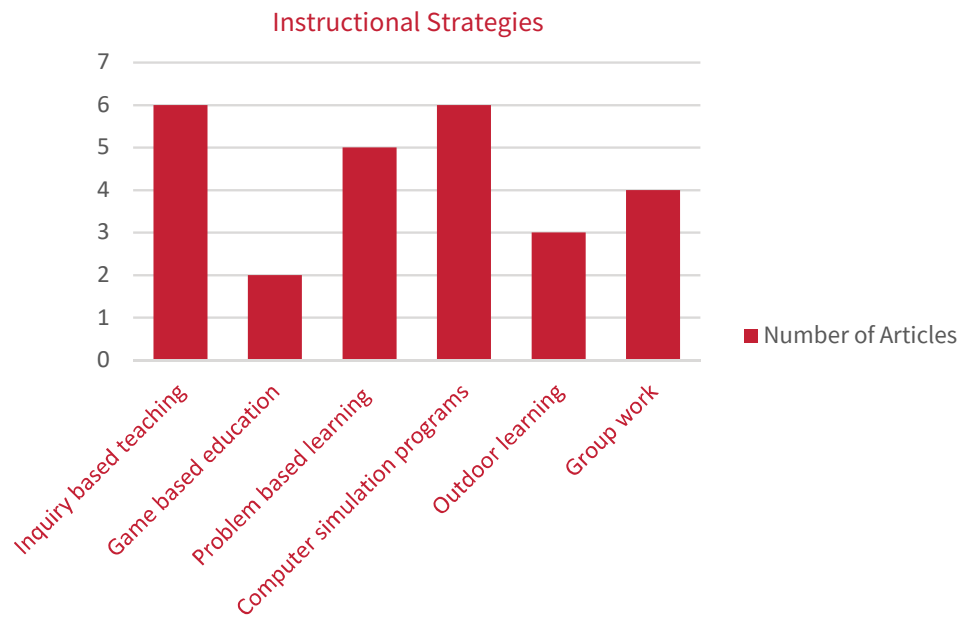

Figure 1. Instructional strategies used in the analyzed articles.

\section{Discussion and Conclusions}

The current problems we encounter are dynamic, complex and wicked sustainability problems, such as climate change, biodiversity loss, poverty, and 
the degradation of ecosystems (Chandler and Boutilier 1992; Wiek et al. 2011). Systems thinking is necessary to gain insight into these interrelated problems and to produce sustainable solutions (Capra and Luisi 2014). Systems thinking needs to be applied in science and sustainability education, in order to understand complex systems, such as ecosystems, socio-cultural and economic systems. Students can only actively participate in sustainability actions when these complex and dynamic relationships are understood (Riess and Mischo 2010). Therefore, systems thinking is a critical skill in science and sustainability education. Karaarslan-Semiz and Teksöz (2020) emphasized the importance of fostering pre-service science teachers' systems thinking skills so that they can contribute to developing the systems thinking skills of their future students.

Through this literature review, various topics, research methods and systems thinking models in the selected research studies were examined. Furthermore, the gaps in systems thinking research in the science and sustainability education context were explored. In the analyzed articles, the majority of the researchers focused on sustainability problems, ecosystems and the components of the earth system (particularly the water cycle). The earth system is a complex and dynamic system including interactions between the subsystems of the earth, and human activities impact the whole system (National Research Council NRC). Systems thinking is a good perspective to understand how the earth system works. Within the framework of National Research Council (NRC), it was emphasized that, before students proceed to secondary school, they should understand the major systems of Earth (geosphere, hydrosphere, atmosphere and biosphere). They should understand that there is always interaction among Earth's systems (Lee et al. 2019). For this reason, researchers have assessed the systems thinking skills of students in the subjects of water cycle, carbon cycle, ecosystems or climate system (e.g., Shepardson et al. 2014; Ben-Zvi-Assaraf and Orion 2010b). In the analyzed articles, sustainability problems were also used as a topic to determine the systems thinking skills development of students. A holistic view of global sustainability problems helps learners see the comprehensive picture and contribute to problem solving (Connell et al. 2012).

This literature review further revealed that researchers mostly conducted systems thinking studies with lower secondary school students. In the literature, there are some discussions about the age and grade level that are appropriate for teaching systems thinking skills (Lee et al. 2019). As the systems thinking is a higher order skill and difficult to foster, it is important to engage students in all age groups and grade level (Zohar and Dori 2003). Ben-Zvi-Assaraf and Orion (2010b) suggested that systems thinking skills can be taught and mastered at elementary school level. 
Therefore, in the future, more studies relevant to systems thinking skills development can be conducted with elementary school students. In the current analysis, it was found that fewer studies focused on developing student teachers' and undergraduate students' systems thinking skills. Fanta et al. (2019) pointed out that studies on how to improve the systems thinking skills of adults are limited. Future systems thinking studies may be conducted in the higher education level. For instance, more intervention studies can be administered to foster the systems thinking skills of student teachers, as they can facilitate the learning environment to improve their future students' systems thinking skills. Science teachers and teachers linked to sustainability related subjects should have fundamental knowledge of system science and the ability to apply this knowledge to solve sustainability problems (Fanta et al. 2019). Therefore, in order to enhance the systems thinking skills of teachers, systems thinking should be integrated into teacher education programs. More research can be conducted to develop the systems thinking curricula in teacher education.

According to the data analysis, qualitative research tools including written assessments and interviews were mostly preferred to assess systems thinking skills. In addition to qualitative tools, multiple assessment techniques such as Likert type questionnaires, scales and two or three tier tests can be used to measure systems thinking skills. Brandstadter et al. (2012) argued that there is a need to develop appropriate measurement tools to assess systems thinking skills in educational studies.

In terms of research methodology, more than half of the examined studies included intervention studies and described different instructional strategies. The most common instructional strategies applied to foster systems thinking skills were inquiry-based teaching and computer simulation programs. Researchers also used problem-based learning and group work in the intervention studies. The least mentioned instructional strategies were outdoor learning and game-based education. Ben-Zvi-Assaraf and Orion (2010a) emphasized that inquiry-based outdoor and indoor learning activities can be effective to develop students' systems thinking skills. According to Fanta et al. (2019), problem-based instruction is an effective tool to develop a deeper understanding of complex systems. Jeronen et al. (2017) also emphasized that field work, field trips and problem-based activities are useful strategies to develop students' knowledge and interest in sustainability. Therefore, more intervention studies can focus on both indoor and outdoor learning strategies, to enhance the systems thinking skills of students.

Lastly, systems thinking models used in the selected articles were examined. In the published studies to date, different systems thinking models have been 
used according to the context of the research studies. The majority of the researchers used the systems thinking hierarchical model, complex systems and structure-behavior-function model as a framework. Researchers and educators agree that systems thinking is critically important to understand the complexity of the current problems and to propose solutions to them (e.g., Senge 1990; Meadows 2008; Arnold and Wade 2015). However, a variety of definitions of systems thinking can be found in the literature. Arnold and Wade (2015) emphasized that there is a need to create a precise definition of systems thinking, including, especially, three kinds of information, namely "purpose", "elements" and "interconnections". Previously, Meadows (2008) emphasized that these three aspects are the crucial components of systems thinking. In this study, it was explored that researchers particularly emphasized several components of systems thinking, which refer to interconnections, dynamic and cyclic relationships, feedback loops, hidden dimensions and time dimensions. Karaarslan-Semiz and Teksöz (2020) pointed to the affective dimensions that can be included in a sustainability education context. In future studies, systems thinking models may include more affective dimensions, such as building empathy with people and non-human beings and developing a sense of connectedness to nature. Affective or psychological factors can be considered in future systems thinking inquiries.

As a conclusion, in the analyzed articles related to science and sustainability education, it was found that researchers investigated different topics and used various measurement tools and research methodologies with different target groups from the primary level to higher education. This literature review revealed that the number of research studies conducted with primary, upper secondary school students and student teachers is limited. Future studies may be conducted with these target groups. In addition to qualitative research, quantitative and mixed research methods can be applied in the systems thinking research. Furthermore, curriculum analysis can be conducted to be able to integrate the systems thinking skills into curriculum programs. In teacher education programs, systems thinking courses can be designed to foster student teachers' skills and their pedagogical content knowledge to teach systems thinking to their students.

In the current times, we have complex problems that need urgent solutions. Developing the systems thinking skills of the individuals is extremely important to build a sustainable future. As this review revealed, more research is needed to nurture and evaluate students' systems thinking skills in science and sustainability education. Especially in disadvantageous regions, systems thinking oriented school programs can be designed to achieve equal and inclusive education and to improve 
learning outcomes for all individuals. Future studies may investigate the ways to integrate systems thinking into science education curriculum and design systems thinking integrated science and sustainability education programs.

Acknowledgments: I would like to thank Arran Stibbe for reading this chapter and giving his valuable comments and suggestions.

Conflicts of Interest: The author declares no conflict of interest.

\section{References}

Arnold, Ross D., and Jon P. Wade. 2015. A Definition of Systems Thinking. A Systems Approach. Procedia Computer Science 44: 669-78. [CrossRef]

Ateşkan, Armağan, and Jennie Farber Lane. 2018. Assessing Teachers' Systems Thinking Skills during a Professional Development Program. Journal of Cleaner Production 17: 4338-56. [CrossRef]

Batzri, Or, Orit Ben-Zvi-Assaraf, Carmit Cohen, and Nir Orion. 2015. Systems: Expressions of Dynamic and CyclingThinking among University Students. Journal of Science Education Technology 24: 761-75. [CrossRef]

Ben-Zvi-Assaraf, Orit, and Nir Orion. 2005. Development of System Thinking Skills in the Context of Earth System Education. Journal of Research in Science Teaching 42: 518-60. [CrossRef]

Ben-Zvi-Assaraf, Orit, and Nir Orion. 2009. A Design Based Research of an Earth Systems Based Environmental Curriculum. Eurasian Journal of Mathematics, Science and Technology Education 5: 47-62. Available online: https://www.researchgate.net/publication/294620611 (accessed on 12 January 2019).

Ben-Zvi-Assaraf, Orit, and Nir Orion. 2010a. Four Case Studies Six Years Later: Developing Systems Thinking Skills in Junior High School and Sustaining Them over Time. Journal of Research in Science Teaching 47: 1253-80. [CrossRef]

Ben-Zvi-Assaraf, Orit, and Nir Orion. 2010b. Systems Thinking Skills at the Elementary School Level. Journal of Research in Science Teaching 47: 540-63. [CrossRef]

Bernier, Andrew. 2017. From Linear Industrial Structures to Living Systems: A Design Shift in Education for Sustainability. Education Sciences 7: 43. [CrossRef]

Booth-Sweeney, Linda. 2017. All systems go. Developing a Generation of Systems Smart Kind. In Rethinking Education on a Changing Planet, 1st ed. Edited by Erik Assadourian and Lisa Mastny. Washington: Island Press, pp. 141-331.

Booth-Sweeney, Linda, and John D. Sterman. 2000. Bathtub Dynamics: Initial Results of a Systems Thinking Inventory. System Dynamics Review 16: 249-86. Available online: https: //onlinelibrary.wiley.com/doi/pdf/10.1002/sdr.198 (accessed on 12 June 2018). [CrossRef] 
Brandstadter, Kristina, Ute Harms, and Jörg Grossschedl. 2012. Assessing System Thinking through Different Concept-Mapping Practices. International Journal of Science Education 34: 2147-70. [CrossRef]

Capra, Fritjof, and Pier Luigi Luisi. 2014. The Systems View of Life: A Unifying Vision. Cambridge: Cambridge University Press, pp. 19-33.

Chandler, Michael J., and Robert G. Boutilier. 1992. The Development of Dynamic System Reasoning. Human Development 35: 121-37. [CrossRef]

Cloud, Jamie P. 2005. Some Systems Thinking Concepts for Environmental Educators during the Decade of Education for Sustainable Development. Applied Environmental Education Communication 4: 225-28. [CrossRef]

Connell, Kim Y. Hiiler, Sonya M. Remington, and Cosette M. Armstrong. 2012. Assessing Systems Thinking Skills in two Undergraduate Sustainability Courses: A Comparison of Teaching Strategies. Journal of Sustainability Education. Available online: https://krex.kstate.edu/dspace/bitstream/handle/2097/13783/Assessing\%20systems\% 20\%20publisher\%27s\%20PDF.pdf?sequence=1 (accessed on 3 June 2019).

Cox, Marjolein, Jan Elen, and An Steegen. 2019. Systems Thinking in Geography: Can High School Students Do It? International Research in Geographical and Environmental Education 28: 37-52. [CrossRef]

Evagorou, Maria, Kostas Korfiatis, Christiana Nicolaou, and Costas Constantinou. 2009. An Investigation of the Potential of Interactive Simulations for Developing System Thinking Skills in Elementary School: A Case Study with Fifth Graders and Sixth-Graders. International Journal of Science Education 31: 655-74. [CrossRef]

Fanta, Daniela, Julia Braeutigam, and Werner Riess. 2019. Fostering Systems Thinking in Student Teachers of Biology and Geography-An Intervention Study. Journal of Biology Education. [CrossRef]

Foley, Rider W., Leanna M. Archambault, Annie E. Hale, and Hsiang K. Dong. 2017. Learning Outcomes in Sustainability Education among Future Elementary School Teachers. Journal of Education for Sustainable Development 11: 33-51. [CrossRef]

Forrester, Jay W. 1992. Road map 1: System Dynamics and Learner-Centered-Learning in Kindergarten through 12th Grade Education (MIT System Dynamics in Education Project). Available online: http://web.mit.edu/sysdyn/sd-intro/D-4337.pdf (accessed on 10 May 2019).

Forrester, Jay W. 2007. System Dynamics-A Personal View of the First Fifty Years. System Dynamics Review 23: 345-58. [CrossRef]

Frankel, Jack, and Norman Wallen. 2006. How to Design and Evaluate Research in Education, 6th ed. New York: McGraw Hill, pp. 482-508.

Gero, Aharon, and Efrat Zach. 2014. High School Programme in Electro-Optics: A Case Study on Interdisciplinary Learning and Systems Thinking. International Journal of Engineering Education 30: 1190-99. 
Golick, Daug, Dauser Jenny, Louise Lync, and Erin Ingram. 2018. A Framework for Pollination Systems Thinking and Conservation. Environmental Education Research 24: 1143-58. [CrossRef]

Hmelo-Silver, Cindy E., and Merav Green Pfeffer. 2004. Comparing Expert and Novice Understanding of a Complex System from the Perspective of Structures, Behaviors, and Functions. Cognitive Science 28: 127-38. [CrossRef]

Hmelo-Silver, Cindy E., Surabhi Marathe, and Lei Liu. 2007. Fish Swim, Rocks Sit, and Lungs Breathe: Expert-Novice Understanding of Complex Systems. Journal of the Learning Sciences 16: 307-31. [CrossRef]

Hmelo-Silver, Cindy E., Lei Liu, Steven Gray, and Rebecca Jordan. 2015. Using Representational Tools to Learn about Complex Systems: A Tale of Two Classrooms. Journal of Research in Science Teaching 52: 6-35. [CrossRef]

Hogan, Kathleen. 2000. Assessing Students' Systems Reasoning in Ecology. Journal of Biology Education 35: 22-28. [CrossRef]

Hokayem, Hayat, and Ameial Wenk Gotwals. 2016. Early Elementary Students' Understanding of Complex Ecosystems: A Learning Progression Approach. Journal of Research in Science Teaching 53: 1524-45. [CrossRef]

Hokayem, Hayat, Jingjin Ma, and Hui Jin. 2015. Learning Progression for Feedback Loop Reasoning at Lower Elementary Level. Journal of Biology Education 49: 246-60. [CrossRef] Jeronen, Eila, Irmeli Palmberg, and Eija Yili Panula. 2017. Teaching Methods in Biology Education and Sustainability Eucation Including Outdoor Education for Promoting Sustainability-A Literature Review. Education Sciences 7: 1. [CrossRef]

Jin, Hui, Hyo Jeong Shin, Hayat Hokayem, Farah Qureshi, and Thomas Jenkins. 2019. Secondary Students' Understanding of Ecosystems: A Learning Progression Approach. International Journal of Science and Mathematics Education 17: 217-35. [CrossRef]

Jordan, Rebecca C., Wesley R. Brooks, Cindy Hmelo-Silver, Catherine Eberbach, and Suparna Sinha. 2014. Balancing Broad Ideas with Context: An Evaluation of Student Accuracy in Describing Ecosystem Processes After a System-Level Intervention. Journal of Biology Education 48: 57-62. [CrossRef]

Karaarslan-Semiz, Güliz, and Gaye Teksöz. 2019. Sistemsel Düşünme Becerilerinin Tanımlanması, Ölçülmesi ve Değerlendirilmesi Üzerine Bir Çalışma: Kavram Haritaları [A Study on Identifying, Measuring and Evaluating Systems Thinking Skills: Concept Maps]. Başkent University Journal of Education 6: 111-26.

Karaarslan-Semiz, Güliz, and Gaye Teksöz. 2020. Developing the Systems Thinking Skills of Pre-Service Science Teachers through an Outdoor ESD Course. Journal of Adventure Education and Outdoor Learning. [CrossRef]

Küçük-Doğanca, Zerrin, and Ali Kerem Saysel. 2018. Developing Seventh Grade Students' Understanding of Complex Environmental Problems with Systems Tools and Representations: A Quasi-Experimental Study. Research in Science Education 48: 491-514. [CrossRef] 
Lavi, Rea, and Yehudit Judy Dori. 2019. Systems Thinking of Pre- and In-Service Science and Engineering Teachers. International Journal of Science Education 41: 248-79. [CrossRef]

Lee, Tammy D., M. Gail Jones, and Katherina Chesnutt. 2019. Teaching Systems Thinking in the Context of the Water Cycle. Research in Science Education 49: 137-72. [CrossRef]

Logan, Marianne. 2018. Challenging the Anthropocentric Approach of Science Curricula: Ecological Systems Approaches to Enabling the Convergence of Sustainability, Science, and STEM Education. In Research Handbook of Childhood Nature. Edited by Amy Cutter-Mackenzie, Karen Malone and Elisabeth Barrat Hacking. Australia: Springer, pp. 1-28.

Meadows, Donella. 1991. System Dynamics Meets the Press. The Global Citizen. Washington: Island Press, pp. 1-12.

Meadows, Donella. 2008. Thinking in Systems: A Primer. London: Earthscan, Available online: https://wtf.tw/ref/meadows.pdf (accessed on 16 April 2019).

Nolet, Victor. 2009. Preparing Sustainability Literate Teachers. Teachers College Record 111: 409-42. Available online: http://www.gcafh.org/edlab/Nolet.pdf (accessed on 4 June 2019).

National Research Council (NRC). 2012. A Framework for K-12 Science Education: Practices, Cross-Cutting Concepts, and Core Ideas. Available online: http://www.nap.edu/catalog/ 13165/a-framework-for-k-12-science-education-practices-crosscutting-concepts (accessed on 10 May 2019).

Nuhoğlu, Hasret. 2014. Güncel Sosyobilimsel Konulara Yönelik Sistem Dinamiği Temelli Kurulan Öğrenci Modellerinin Değerlendirilmesi [Evaluation of Student Models of Current Socio-Scientific Topics Based on Systems Dynamics]. Educational Sciences Theory Practice 14: 1957-75. [CrossRef]

Orion, Nir. 2002. An Earth Systems Curriculum Development Model. In Global Science Literacy. Edited by Victor J. Mayer. Dordrecht: Kluwer Academic, pp. 159-68.

Orion, Nir, and Charles Ault. 2007. Learning Earth Sciences. In Handbook of Research on Science Teaching and Learning. Edited by Sandra K. Abell and Norman G. Lederman. Hillsdale: Lawrence Erlbaum Associates, pp. 653-88.

Osman, Amina, Sultana Ladhani, Emma Findlater, and Veronica McKay. 2017. Curriculum Framework for Sustainable Development Goals. Commonwealth Secretariat. Available online: https://www.thecommonwealth-educationhub.net/wp-content/uploads/2017/01/ Curriculum_Framework_for_SDGs_July_2017.pdf (accessed on 5 September 2019).

Pan, Yi-Ting, and Shu-Chiu Liu. 2018. Students' Understanding of a Groundwater System and Attitudes towards Groundwater Use and Conservation. International Journal of Science Education 40: 564-78. [CrossRef]

Puttick, Gillian, and Eli Tucker Raymond. 2018. Building Systems from Scratch: An Exploratory Study of Students Learning about Climate Change. Journal of Science Education Technology 27: 306-21. [CrossRef] 
Remington-Doucette, Sonya M., Kim Y. Hiller Connell, Cosette M. Armstrong, and Sheryl L. Musgrove. 2013. Assessing Sustainability Education in a Transdisciplinary Undergraduate Course Focused on Real-World Problem Solving: A Case for Disciplinary Grounding. International Journal of Sustainability Higher Education 14: 404-33. [CrossRef] Reynolds, Martin, Christine Blackmore, Ray Ison, Rupesh Shah, and Elanie Wedlock. 2018. The Role of Systems Thinking in the Practice of Implementing Sustainable Development Goals. In Handbook of Sustainability Science and Research. Edited by Walter Leal Filho. Switzerland: Springer, pp. 667-97.

Richmond, Barry. 1991. Systems Thinking: Four Questions. Creative Learning Exchange. Available online: https://www.iseesystems.com/resources/articles/download/four-keyquestions.pdf (accessed on 6 May 2019).

Richmond, Barry. 1993. Systems Thinking: Critical Thinking Skills for the 1990s and Beyond. Systems Dynamics Review 9: 113-33. Available online: http://citeseerx.ist.psu.edu/viewdoc/ download?doi=10.1.1.35.7685\&rep=rep1\&type $=$ pdf (accessed on 6 May 2019). [CrossRef] Riess, Werner, and Christoph Mischo. 2010. Promoting Systems Thinking through Biology Lessons. International Journal of Scence Education 32: 705-25. [CrossRef]

Rodriguez, Manuel, Raquel Kohen, and Juan Delval. 2014. Children's and Adolescents' Thoughts on Pollution: Cognitive Abilities Required to Understand Environmental Systems. Environmental Education Research 21: 76-91. [CrossRef]

Rosenkranzer, Frank, Christian Hörsch, Stephan Schuler, and Werner Riess. 2017. Student Teachers' Pedagogical Content Knowledge for Teaching Systems Thinking: Effects of Different Interventions. International Journal of Science Education 39: 1932-51. [CrossRef] Roychoudhury, Anita, Daniel P. Shepardson, and Andrew S. Hirsch. 2017. Systems Thinking and Teaching in the Context of Climate System and Climate Change. In the Teaching and Learning about Climate Change. Edited by Daniel P. Shepardson, Anita Roychoudhury and Andrew S. Hirsch. New York: Routledge, pp. 29-42.

Sandri, Orana Jade. 2013. Threshold Concepts, Systems and Learning for Sustainability. Environmental Education Research 19: 810-22. [CrossRef]

Schuler, Stephen, Daniela Fanta, Frank Rosenkraenzer, and Werner Riess. 2018. Systems Thinking Within the Scope of Education for Sustainable Development. A Heuristic Competence Model as a Basis for Science Teacher Education. Journal of Geography in Higher Education 42: 192-204. [CrossRef]

Senge, Peter. 1990. The Fifth Discipline: The Art and Practice of the Learning Organization. New York: Crown Publishing.

Shepardson, Daniel, Anita Roychoudhury, Andy Hirsch, Dev Niyogi, and Sara M. Top. 2014. When the Atmosphere Warms it Rains and Ice Melts: Seventh Grade Students' Conceptions of a Climate System. Environmental Education Research 20: 333-53. [CrossRef] 
Sleurs, Willy. 2008. Competences for Education for Sustainable Development (ESD) Teachers. A Framework to Integrate ESD in the Curriculum of Teacher Training Institutes. Belgium: Commenius 2.1 Project. Available online: https://platform.ue4sd.eu/downloads/CSCT_ Handbook_11_01_08.pdf (accessed on 20 January 2019).

Stave, Krystyna, and Megan Hopper. 2007. What Constitutes Systems Thinking? A Proposed

Taxonomy. In Proceedings of the 25th International Conference of the System Dynamics Society, Boston, MA, USA, 29 July-2 August 2007; Available online: https: //pdfs.semanticscholar.org/506d/f8001a8b9190a6f9b22abf7c1495e96de72d.pdf (accessed on 20 January 2018).

Sterling, Stephen, Paul Maiteny, Deryck Irving, and John Salter. 2005. Linking Thinking: New Perspectives on Thinking and Learning for Sustainability. Available online: http: //assets.wwf.org.uk/downloads/linkingthinking.pdf (accessed on 10 December 2018).

Tolppanen, Sakari, and Maija Aksela. 2018. Identifying and Addressing Students' Questions on Climate Change. The Journal of Environmental Education 49: 375-89. [CrossRef]

United Nations (UN). 2019. The Sustainable Development Goals Report. Available online: https://unstats.un.org/sdgs/report/2019/The-Sustainable-Development-GoalsReport-2019.pdf (accessed on 10 October 2019).

UNECE. 2011. Learning for the Future. Competences in Education for Sustainable Development. Available online: https://www.unece.org/fileadmin/DAM/env/esd/ESD_ Publications/Competences_Publication.pdf (accessed on 10 July 2019).

UNESCO. 2018. Issues and trends in Education for Sustainable Development. Available online: https://unesdoc.unesco.org/ark:/48223/pf0000261445 (accessed on 10 February 2019).

Wiek, Arnim, Loren Withycombe, and Charles L. Redman. 2011. Key Competencies in Sustainability: A Reference Framework for Academic Program Development. Sustainability Science 6: 203-18. [CrossRef]

Wilensky, Uri, and Mitchel Resnick. 1999. Thinking in Levels: A Dynamic Systems Approach to Making Sense of the World. Journal of Science Education and Technology 8: 3-19. Available online: https://link.springer.com/content/pdf/10.1023/A:1009421303064.pdf (accessed on 15 April 2019). [CrossRef]

Zangori, Laura, and Jason A. Koontz. 2017. Supporting Upper-Level Undergraduate Students in Building a Systems Perspective in a Botany Course. Journal of Biology Education 51: 399-411. [CrossRef]

Zohar, Anat, and Yehudit Dori. 2003. Higher Order Thinking Skills and Low-Achieving Students: Are They Mutually Exclusive? The Journal of Learning Sciences 12: 145-81. [CrossRef]

(C) 2021 by the authors. Licensee MDPI, Basel, Switzerland. This article is an open access article distributed under the terms and conditions of the Creative Commons Attribution (CC BY) license (http://creativecommons.org/licenses/by/4.0/). 



\title{
Finnish Subject Student Teachers' Views on Their Social Competencies at the End of Their Educational Studies
}

\author{
Eija Yli-Panula, Eila Jeronen, Sofia Vesterkvist and Pekka Tolonen
}

\section{Introduction}

The study described in this paper is part of the project OVET (Opettajankoulutuksen valinnat-ennakoivaa tulevaisuustyötä) concerning the Finnish primary and subject teachers' competencies (Metsäpelto et al. 2020). The aim of the study is to examine the Finnish subject student teachers' social competencies in teaching students about sustainable development (SD) with respect to local, regional, and global environmental issues. The primary focus is on the United Nations' Sustainable Development Goal 4 (SDG4), which includes ensuring inclusive and equitable quality education and promoting lifelong learning opportunities for all. SDG4 pertains to the quality of education for improving the quality of life through innovative solutions to the world's greatest problems (UNESCO 2017).

Teacher qualification in Finland depends on a university-based education. The subject teacher qualification requires 180 European Credit Transfer and Accumulation System (ECTS) credits for a lower degree and at least 120 ECTS credits for a university degree, which includes or is supplemented by courses totalling at least 60 ECTS credits in teacher pedagogical studies. Pedagogical studies offer a wide range of qualifications for teaching in basic, high school, and other educational institutions. They consist of basic and specific subject studies in education and include education in science and studies of science as a subject as well as teaching practice. In addition, the subject teacher is required to have sufficient subject matter knowledge (Korppas 2008, p. 2). The participants of this survey were subject student teachers from Finnish-speaking universities. The results were redrived from content-based analyses.

Humans impact the physical environment in many ways: overpopulation, pollution, burning fossil fuels, and deforestation. These factors have triggered climate change, soil erosion, poor air quality, and undrinkable water. These resulting negative impacts can affect human behavior. Education is seen as a means to guide the human community towards sustainable lifestyles as it has been found to positively affect both environmental awareness and attitudes (Nisiforou and Charalambides 
2012; Fletcher 2000). Thus, the important questions are: What should be taught in the future? What should future teachers be able to do? What do subject student teachers feel they are capable of or prepared to do? and What do they think they can do as teachers?

Sustainable development education (SDE) aims at sustainability and a sustainable society. It addresses environmental issues and $\mathrm{SD}$ as both developing and improving the living environment, as well as ensuring the participation and empowerment of the people. It also increases awareness of environmental issues and their social impacts, negotiating what issues to address, promoting environmental justice, and gathering the resources and partners necessary to confront these issues. Thus, SDE supports the achievement of the United Nations' SD goals (UNESCO 2017).

The way individuals work at school is influenced by the school culture, a historically mediated system of meaning. Its elements are the norms, values, beliefs, ceremonies, rituals, traditions and myths of the school community (Stolp 1994; Silvera 2017). Therefore, the focus of SDE should be on action competence, critical thinking, deliberation, and understanding how one's choices affect local, national, and global societies and the entire biosphere (Wolff et al. 2017). Action competence is part of social skills and competencies (Metsäpelto et al. 2020).

\section{Theoretical Background}

\subsection{Bronfenbrenner's Ecological Environmental Theory}

In this study, student teachers are thought to live and study in an environment comparable to that described by Bronfenbrenner. According to Bronfenbrenner (1994) ecological environment theory, the individual is an active factor affecting the environment, which must adapt to the conditions of the environment. The environment is understood to consist of nested entities of various scales and their interrelationships within micro-, meso-, exo-, macro-, and chronosystems. A microsystem is a pattern of activities, social roles, and interpersonal relations experienced by the developing person in a given face-to-face interaction. A mesosystem is a system of microsystems. An exosystem comprises the linkages and processes taking place amongst two or more settings, at least one of which does not contain the developing person, but in which events occur that indirectly influence processes within the immediate setting in which the developing person lives. A macrosystem consists of the overarching pattern of the micro-, meso-, and exosystem characteristics of a given culture or subculture, with particular reference to the belief systems, bodies of knowledge, material resources, lifestyles, opportunity structures, hazards, and life course options that are embedded 
in each of these broader systems. A chronosystem encompasses change or consistency over time, not only of the characteristics of the person but also of the environment in which that person lives (Bronfenbrenner 1994).

\subsection{Teachers' Competencies in Connection to the MAP Model and Social Competences}

The multidimensional adapted process (MAP) model of teaching is based on the study of Blömeke et al. (2015). A MAP model consists of the following: (a) dimensions of competencies, (b) situation-specific skills, and (c) professional practices (Metsäpelto et al. 2020). Dimensions of competencies are divided into five groups. Cognitive competencies are (1) the knowledge base for teaching and learning and (2) cognitive skills. Non-cognitive competencies are (3) social skills, (4) personal orientations and (5) professional well-being. The focus of this article is on the social skills.

Teachers need social skills both in the classroom as well as when working with colleagues outside the classroom. This has been attested to in the literature (Jennings and Greenberg 2009). This has also been supported by the responses that primary school teachers have given in the ongoing survey at the University of Turku for students five years after they have graduated. According to these findings, the most important working life skill is the ability to cooperate (Aarresaari 2017).

The MAP model further divides social skills into relational skills, emotional competency, diversity competency, and intercultural competency and interaction. Relational skills are needed to be able to act constructively and reciprocally take into account others' views and to be able to listen to and provide others with the personal and professional space they need. This also includes negotiating and conflict management. Emotional competency, in turn, consists of the ability to perceive and recognize one's own and others' emotions and their causes and effects. An emotionally competent teacher is also able to regulate and express emotions in an appropriate way. Diversity competency involves the ability of a teacher to see and value every child as an individual. It also means that the teacher possesses the skills to prevent processes of marginalization and to promote the furtherance of equality and participancy. Intercultural competency and interaction give the teacher the ability to interact and communicate in multicultural contexts. Thus, the teacher is sensitive to how ethnicity, language, age, religion, gender, sexuality, and social class can lead to oversimplifications, misunderstandings, and prejudices.

This article focuses mostly on relational skills and the emotional competency of the subject teacher students. 


\subsection{Teachers' Competencies in SDE}

According to Brundiers and Wiek (2017), the knowledge dimensions required for integrative SD include content knowledge, methodological skills, communication skills, collaborative teamwork, participant engagement, project leadership ability, continuous learning ability, and self-care. According to UNESCO (2017), the key competences for sustainability comprise the following eight different competencies. Systems thinking competency (e.g., to recognize and understand relationships and analyze complex systems), anticipatory competency (e.g., to understand and evaluate multiple futures, create one's own visions for the future, and deal with risks and changes), and normative competency (e.g., to understand and reflect on the norms and negotiate sustainability values that underlie one's actions to principles, goals, and targets) are situated in the cognitive domain (Velazquez and Rivas 2020). According to Velazquez and Rivas (2020), the socio-emotional domain comprises strategic competency (e.g., to collectively develop and implement innovative actions), collaboration competency (to learn from others) and critical thinking competency (e.g., to question norms, practices, and opinions; to reflect on one's own values, perceptions, and actions), and the behavioral domain includes-for its part-self-awareness competency (e.g., the ability to reflect on one's own role in the local community and global society) and integrated problem-solving competency (e.g., the ability to develop solution options to promote sustainable development by integrating the abovementioned competences).

The key competencies for sustainability can be understood as "transversal, multifunctional and context independent" (Rychen and Salganik 2003). They represent the particularities that citizens who work to achieve sustainability need to sort out at present, as well as complex forthcoming challenges. They are relevant to all SDGs and enable individuals to relate the different SDGs to each other-to see 'the big picture' of the 2030 Agenda for Sustainable Development (United Nations 2015). The key competencies represent cross-cutting competencies that are necessary for all learners of all ages worldwide. Thus, teachers, including subject teachers, should be able to master the issues concerning the key competences for sustainability and be able to apply their knowledge in teaching situations.

\subsection{Strategies for SDE in Finnish Subject Student Teachers' Studies}

On the one hand, policy documents and strategies request SDE at all levels, including teacher education in Finland. On the other, Finnish universities are autonomous when it comes to decisions regarding the scope of SDE and practice, and there are no common models for how to integrate SDE into university courses 
and teacher education (Wolff et al. 2017). SDE is seldom compulsory in Finnish subject student teachers' study programs. As a result, there is great variation in teacher educators' knowledge and skills about how to integrate and teach SD issues to the subject student teachers. This ultimately means that the main responsibility lies with the biology and geography educators with a particular focus on ecological SDE. The other two dimensions, economic as well as social and cultural SDE, are also introduced. Both the worldviews and methods of solving worldwide problems are seen in the Finnish policymaking documents and strategies (Ministry of Education 2006; Ministry of the Environment 2007).

National policy documents and action plans describe goals and offer ideas on how to implement SD at all levels of education (Ministry of Education 2006; Ministry of the Environment 2007). In these documents, the citizens are strongly encouraged to learn to maintain social, cultural, and economic well-being without depleting natural resources or overloading nature's delicate balance. According to Wolff et al. (2017), this means that the role of education and training is to ensure that all citizens have the knowledge, skills, readiness, and vision that will enable them to build a sustainable and reasonable future and commit to a sustainable way of life. According to the Basic Education Act (Finlex 2001), social dimensions of the SDE are emphasized, such as responsibility and collaboration promoting tolerance as well as trust among human groups, people, and cultures.

The emphasis on SD regarding teacher education curricula has become stronger in recent years, but differences exist amongst the teacher education programs of Finnish universities. Due to the diverse strategic goals of the universities, the SD goals might be difficult to achieve in Finnish teacher education programs (Wolff et al. 2017). This means that SDG4 - which relates to the quality of education as part of student teachers' 'social competencies' in teaching SD, which is within the focus of this study - may not be attainable. Thus, we decided to study the Finnish subject student teachers' competencies, especially the social competencies.

\section{Research Questions (RQs)}

Wolff et al. (2017) have argued that qualified Finnish education fails in SDE. In response to their study, the authors wanted to investigate what subject student teachers regard as core environmental problems in SDE (RQ1), while also focusing on the subject student teachers' social competencies (RQs 2, 3, and 4). The four RQs of the study are as follows:

1. What kind of environmental problems do the subject student teachers regard as core environmental problems at the local, regional, and global levels? 
2. What kind of opportunities do the subject student teachers feel they have to socially influence these local, regional, and global environmental issues?

3. How do the subject student teachers identify and understand the social relationships in the classroom?

a. How keen is the subject student teacher in participating in social communication?

b. What kind of social capacity does the subject student teacher think she/he has?

c. What kind of things does the subject student teacher think influences her/his decision-making?

4. How do the subject student teachers view their likelihood to influence the future school culture with respect to SD at the school where they work?

a. How keen is the subject student teacher in participating in the development of the school culture regarding SD?

b. What kind of things does the subject student teacher think influences her/his decision-making?

In the Material and Methods section, the analyses are presented according to RQs $1-4$ and questions in the questionnaire.

\section{Materials and Methods}

\subsection{Collection Methods of Material}

The material was collected using a web-based questionnaire (Webropol 2.0) in the spring of 2019. The target group consisted of the subject student teachers who spoke Finnish as a first language and who had completed at least $25 \%$ of their pedagogical studies before the survey. A total of 1200 subject student teachers from six universities in Finland were sent an invitation to participate in the survey and the link to the questionnaire by email. The response time was six weeks and three days. Two reminders of the survey were sent to the prospective participants. Participation in the study was voluntary, and the subject student teachers were allowed to complete the questionnaire at the time and place most convenient for them. However, due to the voluntary nature of the survey, the target population may not have been uniform, and the survey may have been answered in very different environments and situations. 
In total, 142 subject student teachers responded to the survey. However, the answers of four of subject student teachers were excluded from the analysis of the results because they had not yet completed at least $25 \%$ off their pedagogical studies. The final analysis thus covers the responses of 138 subject student teachers. The majority of the respondents were women $(74.6 \%)$ aged $20-29$ years $(69.6 \%)$. Of the remaining respondents, $30.4 \%$ were over 29 years of age, and approximately $82 \%$ had completed most of their pedagogical studies (over 75\%); however, most had little to no experience in actual teaching $(83.3 \%)$. The respondents studied natural sciences, mathematics, humanities, their mother tongue, and foreign languages. Additionally, one subject student teacher was studying physical education, and two participated in adult education.

\subsection{Analysis Methods}

The research material was primarily handled in a data-driven manner. However, Saloranta's doctoral dissertation's themes of social and cultural sustainability, as well as UNESCO's definition of SD and SDGs, were used to formulate the questions on the questionnaire (Saloranta 2017; UNESCO 2017). The questionnaire included both open-ended and multiple-choice questions, and its main focus was on the open-ended questions. The questions dealt with SD and students' social skills, but these themes were not specially addressed directly in the questions to the subject student teachers. The estimated duration of the survey was $15 \mathrm{~min}$. The following sections describe the questions in the questionnaire and their analysis in more detail.

\subsubsection{The Subject Student Teachers' Perception of Major Environmental} Problems (RQ1)

The kind of environmental problems the subject student teachers regarded as core environmental problems at local, regional, and global levels were the initial focus of the study (RQ1). In the questionnaire, the subject student teachers were asked about the key environmental problems at each individual level. To avoid overlapping in analyses, a clear division was made between ecological, economic, social, and cultural problems.

In the study, the problems of pollution and destruction of terrestrial or aquatic ecosystems, biodiversity, climate change, and air pollution were classified as ecological environmental problems. The economic problems of the environment were defined as those related to people's unsustainable lives: overconsumption, point sources, traffic, and waste. For example, traffic encompassed both the heavy use of transport and the disadvantages of public transport. Similarly, waste referred to a large amount 
of waste, littering, and deficiencies in waste management, whereas overconsumption referred to the excessive use of matter and energy, such as favoring instant fashion and unsustainable returns on energy. The point sources mainly dealt with factories but also agricultural emissions. Social and cultural problems included human health and well-being and such human rights as access to food, water, and education as well as equality.

\subsubsection{The Subject Student Teachers' Opportunities to Influence on Environmental Problems (RQ2)}

Secondly, the kind of opportunities the subject student teachers felt they had to socially influence the local, regional, and global environmental issues were studied. The subject student teachers were also asked how and with whom they would solve the environmental problems. Here, too, they were allowed to respond individually at different levels. The answers of the subject student teachers were divided by further sorting them into different solutions based on their impact on other people and their knowledge, views, and decisions. The solutions included collaboration, education, and influencing attitudes (action to change attitudes) or policies (civic participation). Attitudes can be affected by setting an example for others or by increasing the positive interest of others in the environment. Policies can have an influence by voting, strikes, or other methods of manifestation. Social solutions also involve policy decisions, volunteering, and various forms of innovation and research for SD. Social action, in turn, can lead to more sustainable neighborhoods and influence people's consumption choices. The key impact of policy decisions is described, for example, in the following answer:

The use of fossil fuels and other emissions-producing activities can both be enforced and directed to more environmentally friendly activities through legislation and taxation. It creates a situation where there are no other cost-effective and sensible solutions. (female student $136=$ F136, at the regional level, policy decision)

The subject student teachers were also asked whom the students thought is responsible for solving environmental problems. Three categories were used in analyzing the subject student teachers' answers. If the subject student teachers included themselves as problem-solvers, the answer was labeled ' $I$ '. If subject student teachers mentioned other problem-solvers, but not themselves, the answer was labeled 'others'. If the answer contained no solver, the answer was marked as 'not detectable'. 
4.2.3. The Subject Student Teachers' Understanding of the Social Relationships in the Classroom (RQ3)

The third research question concerned how the subject student teachers identified and understood the social relationships in the classroom. One question in the questionnaire was designed to determine the subject student teachers' actions in two school-related social situations from the teacher's perspective. The questionnaire included different statements for students to choose from. How to solve the school-related social situations concerning disputes in the class was the focus of the first question (Part 1), and organization of a class trip was the focus in the second one (Part 2).

In the first question, the following case was presented: Two students started to argue in the classroom after the teacher left the class. It was possible to resolve the situation by either promptly returning the students to their seats, letting the headmaster talk to the quarrelers, or by dealing with the dispute either in the classroom or in the corridor. The subject student teachers were also asked to justify their choices. In a question regarding the organization of a class trip, the teacher had to contact the tour staff because all students did not fit within the capacity of the tour. The subject student teachers were able to explain their own ways to solve the situation. Frequent themes were picked from the subject student teachers' answers focusing on what kind of things affected their decision-making.

The following statements were also made to the subject student teachers (Part 3): 1. Continuous economic growth is possible; 2. Economic equality will be achieved between the welfare states and developing countries in the next few years; 3. The school day should start at eight o'clock; 4. Finland can afford to cut forests at the current rate; and 5. The traffic rules should always be followed. This article does not elaborate on the subject student teachers' reasoning for these statements, but it defines the subject student teachers' confidence in their own opinions. Certainty of subject student teachers' confidence in their own opinions was divided into strong opinions, statements, beliefs, and uncertain opinions. Strong opinions used an exclamation mark or other means of confirmation, such as 'of course' or 'definitely', in sentences related to the reality of the statement. In turn, beliefs used mitigating expressions or emphasized one's own opinion, such as 'probably' and 'I think'. In uncertain opinions, the subject student teachers clearly stated that they did not control the subject and did not know if their answer was correct. 
4.2.4. The Subject Student Teachers' Likelihoods to Influence the School Culture with Respect to SD (RQ4)

Firstly, the study sought to determine how the subject student teachers saw their likelihood to influence the school culture with respect to SD at the school where they worked in the future with respect to sustainable development. RQ4 had two secondary questions: How keen is the subject student teacher in participating in the development of the school culture regarding SD? and What kinds of things the student thinks influence her/his decision-making? The subject student teachers' general interest in influencing their school environment from the perspective of SD was also studied. The question was implemented on a sliding scale divided into 10 sections, where 8-10 meant interested and 10 very interested in SD. Secondly, the subject student teachers were asked an open-ended question about a problem in their school community and their more specific thoughts on how to solve it. Thirdly, they were asked to choose the three most important ways of influencing school culture based on the themes of social and cultural sustainability presented by Saloranta (2017).

According to Saloranta, the themes that meet the criteria of social and cultural sustainability are the well-being of staff and students, school and school safety, prevention of bullying and exclusion, student care and other learning support, cultural environment, customs and traditions, and multiculturalism and internationality. In the questionnaire, the corresponding options included a vegetarian food day once a week, reducing traffic speeds near the school, reducing online bullying with a specialist visit, setting up a hobby club for school pupils' leisure activities, learning about local cultural sites and landscapes, and taking the celebration culture of minority groups into account in school activities. The options in the questionnaire did not directly follow the same principles as the SD themes; for example, a vegetarian food day involves not only well-being but also an ecological approach. However, they were all central to the values of social and cultural SD.

\section{Results}

\subsection{The Subject Student Teachers' Perception of Major Environmental Problems (RQ1)}

The subject student teachers mentioned ecological and economic environmental problems more often than cultural and social problems and other environmental problems (Figure 1). Economic problems were most often mentioned at the local level and ecological problems at the global level. 


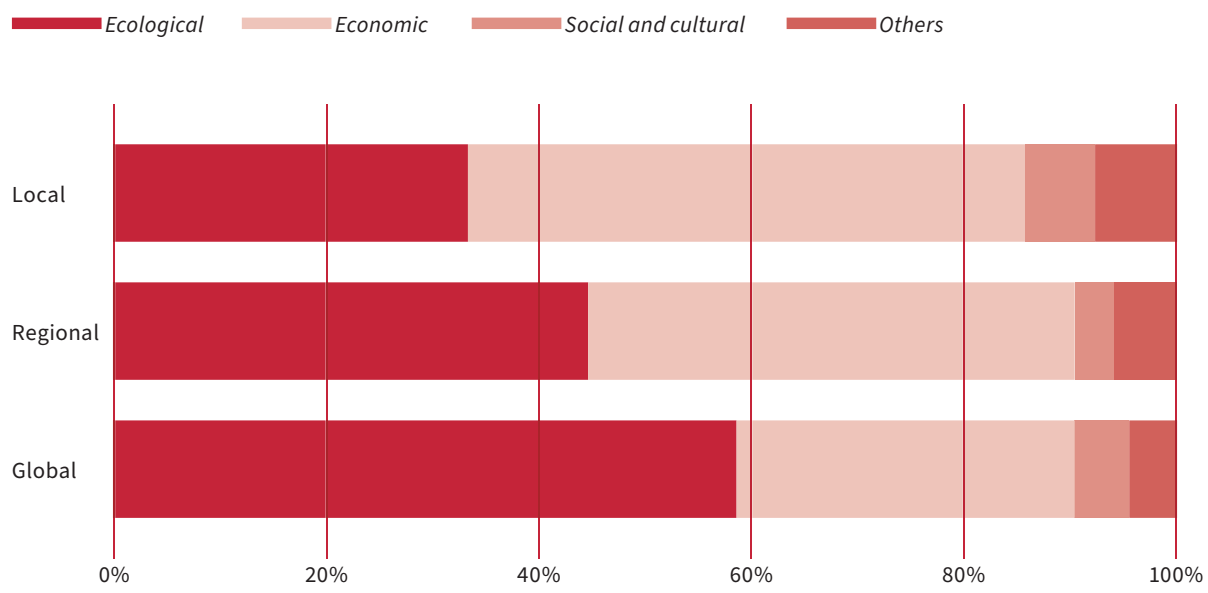

Figure 1. The environmental problems at local, regional, and global levels that were mentioned by the subject student teachers were further divided into ecological, economic, social and cultural problems, as well as other environmental problems. Other environmental problems included problems in the school environment and people's indifference to environmental problems.

Climate change was considered to be the most important environmental problem at the global level; however, it was also mentioned at the local and regional level (Figure 2). Air pollution was also considered as central to global warming as well as other sources of air pollution: traffic, overconsumption, and point sources. In addition to climate change, the respondents mentioned biodiversity loss, land pollution, deforestation, and water pollution. At a regional level, there was concern about logging in Finnish forests and the state of the Baltic Sea. At a global level, rainforests were frequently mentioned. A subject student teacher wrote and explained this as follows: 'Global warming, extreme weather phenomena, ocean acidification. The list is long. I think every one of them is central and interrelated to each other' (F74).

The subject student teachers most often referred to waste at the local level, with an emphasis on littering and lack of recycling. At the global level, they most often mentioned plastic; microplastics in the sea were mentioned only in two answers. The biggest concern in the transport sector was driving private cars and the lack of public transport. At a global level, the effect of airplanes was mentioned a few times. 


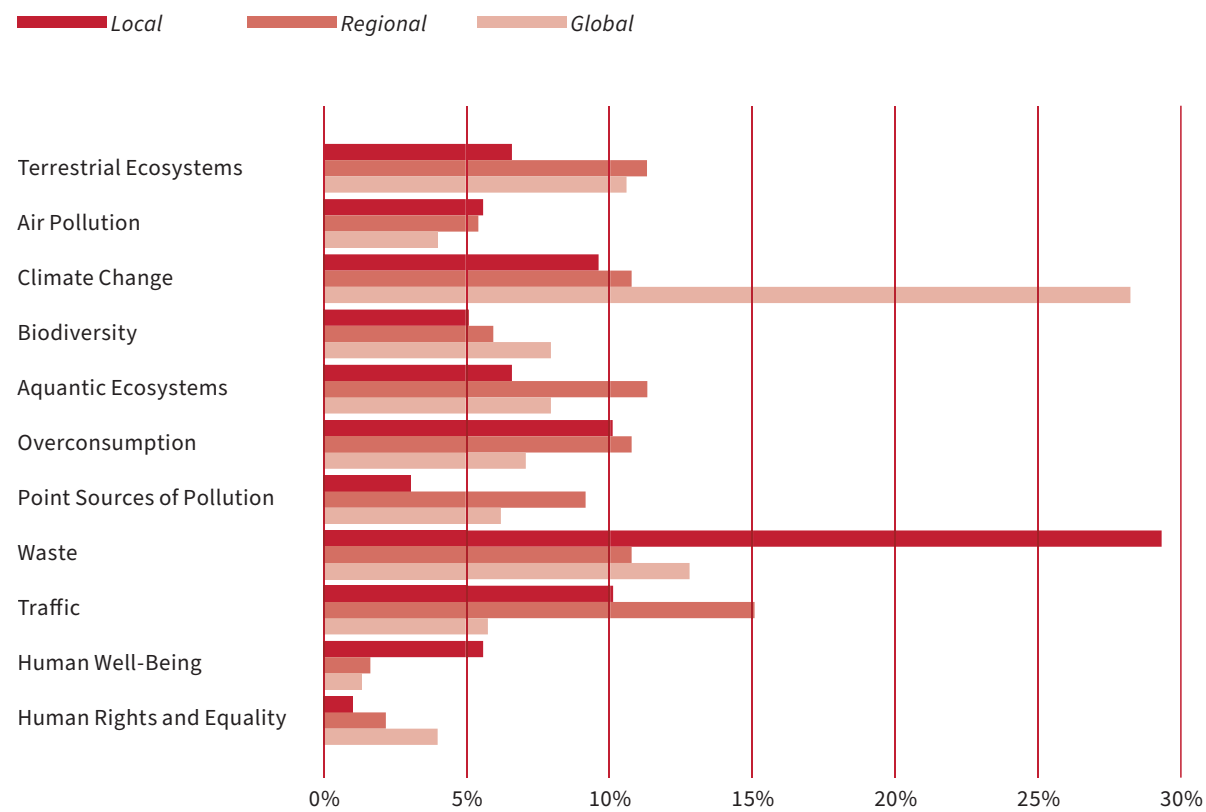

Figure 2. Environmental problems mentioned by the subject student teachers at local, regional, and global levels. The graph only covers ecological (terrestrial ecosystem, air pollution, climate change, biodiversity, aquatic ecosystem), economic (overconsumption, point sources of pollution, waste, traffic), and social and cultural (human well-being, human rights, equality) environmental issues. In addition, the subject student teachers mentioned problems in the school environment and the general disregard for the environment.

There were a few mentions of social and cultural problems. Problems affecting well-being included health problems caused by poor air quality. Human rights problems referred to famine and depletion of clean drinking water, as well as refugee and human inequality. The inequality of women was highlighted in the context of the problems caused by population growth. Human genetic engineering was seen as a threat to the future.

\subsection{The Subject Student Teachers' Opportunities to Influence on Environmental Problems (RQ2)}

The subject student teachers found international cooperation and reasonable construction to be important in solving environmental problems (Figure 3). Reasonable construction was seen as sustainable when it had, for example, 
well-functioning public transport, waste management, and recycling opportunities. Furthermore, the importance of the policy was perceived to be essential at the regional and global levels. At the local level, in particular, household consumption choices and education were considered necessary.

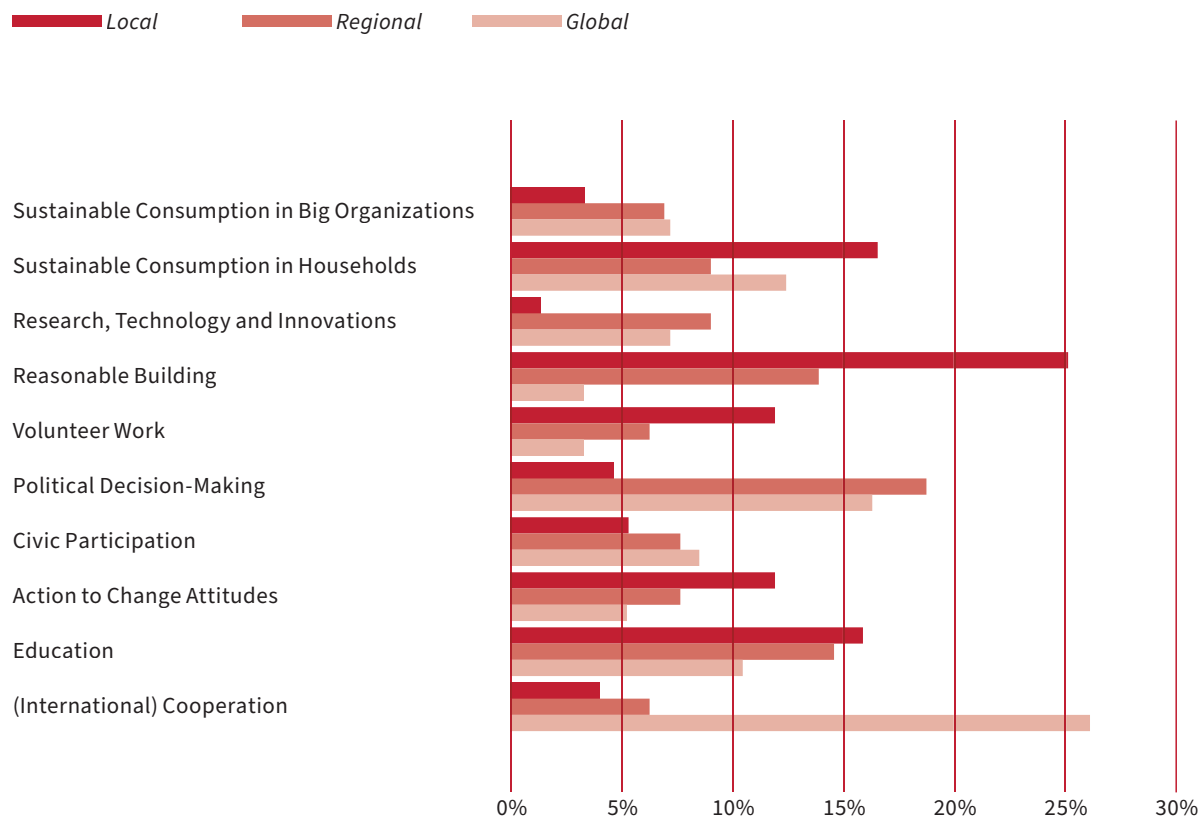

Figure 3. The solutions for environmental problems at local, regional, and global levels mentioned by the subject student teachers.

In most of the answers, the subject student teachers excluded themselves from the solvers of the environmental problems, and only the responsibility of other parties was identified (Figure 4). Some of the answers did not identify the solvers at all, and in the remaining answers, the subject student teachers presented themselves as the solvers of environmental problems. For example, the family, school pupils and staff, big companies, policymakers, the European Union, UNESCO, the United Nations, and rich nations were mentioned as problem-solvers. The subject student teachers' role in solving environmental problems was less pronounced at the regional and global levels than at the local level. 


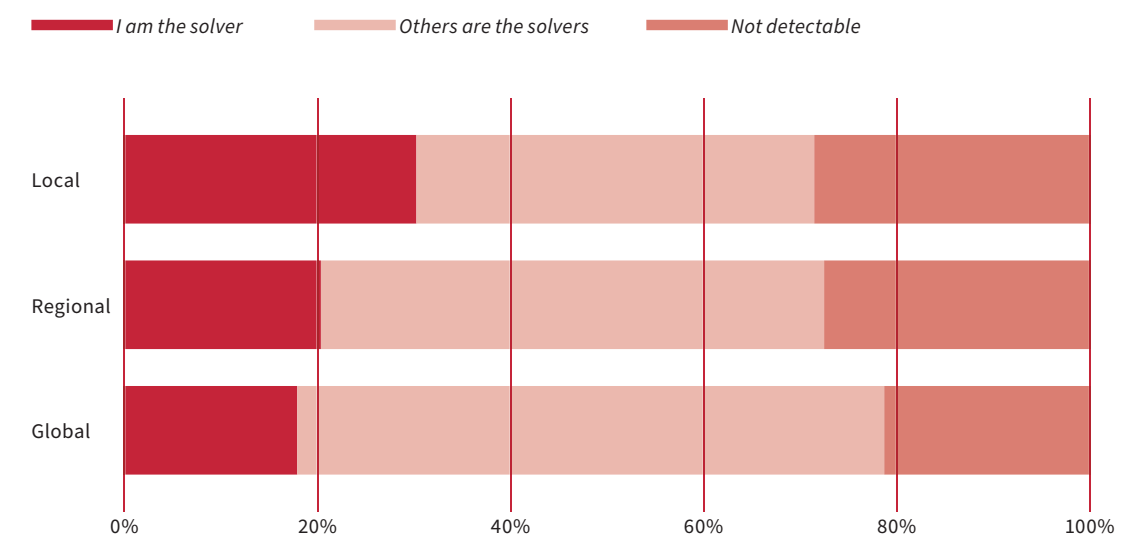

Figure 4. The subject student teachers' views $(n=138)$ on who will act as a solver of environmental problems. In some of the answers, the problem-solver was not detectable, and in some cases, the respondents excluded themselves from the possible problem-solvers (Other). In other responses, the subject student teachers considered themselves to be problem-solvers, either alone or as one of the other problem-solvers (I).

5.3. The Subject Student Teachers' Understanding of the Social Relationships in the Classroom (RQ3)

\subsubsection{Dealing a Dispute in Class (Part 1)}

The questionnaire results indicate that subject student teachers would preferably clarify the situation with the disputants either in the classroom $(42.0 \%)$ or in the corridor $(37.7 \%)$ when dealing with a dispute in class. A minority of the subject student teachers $(20.3 \%)$ thought that they would ignore the dispute and return to the lesson being taught, while no one would ask the principal to settle the dispute, preferring to deal with it themselves. Many subject student teachers mentioned that their solution would depend on either the severity of the dispute and the physicality, personality, or nature and habits of the disputants and other students $(29.0 \%)$.

The subject student teachers who thought that they would quickly deal with the matter were those who initially thought the dispute was small. Some subject student teachers stated that if the dispute was more serious, it could be directed to the principal. Otherwise, the dispute would be dealt with by the teacher and the disputants after the lesson or would be left unresolved. The reason for this choice was that arguing would take class time from other students and reduce their ability and opportunity to learn. The dispute was considered to not belong to other students. The answers emphasized the idea of student equality and their right to learn content. 
For example, one student teacher stated: 'Probably a small dispute so it's best to simply return to the subject' (F21).

The subject student teachers who would resolve the dispute in the corridor emphasized the idea that the dispute must be resolved, but that other students should not be involved in the dispute. The dispute should be dealt with as soon as possible by the teacher dealing with the disputants because that would avoid future problems for the well-being of students, as well as making it easier to pass the subject. The answers also revealed a certain amount of emphasis on educational work. The respondents did not want to include other students in the dispute due to the rights and well-being of individual students and because it allowed others the possibility to focus on the content being taught. The subject student teachers wanted to provide disputants with an equitable and peaceful environment in which to deal with a situation where no one would feel embarrassed or would have to deal with their personal issues in public. They also thought that the private conversation might lead to a more in-depth discussion. Some of the answers also highlighted the teacher's own responsibility in resolving the situation. One subject student teacher wrote:

It is better to have the dispute handled in person, without the class being present, so that things can be talked through. In the meantime, the rest of the class can do tasks, for example. However, the issue should not be ignored but cleared up, and the causes of the dispute should be discussed. (F8)

The subject student teachers who noted that they would settle the dispute in the classroom also indicated a desire to deal with the dispute immediately to avoid future problems. They wanted to settle the dispute amongst everyone, emphasizing the idea that other parties are an indirect part of the situation. This answer emphasized the equality of students, but as mentioned earlier, in most cases, the subject student teachers wanted to teach content in the name of equality, thus addressing the situation with the whole class for the sake of well-being and maintaining a positive atmosphere. In addition, the answers emphasized the role of education alongside the content of the subject and the opportunity created by the situation to develop skills for handling social situations. Some of them also mentioned the school's rule about not leaving the class unattended during the lesson. In addition, they stated that they would not want to leave other students alone to avoid more arguing. One participant expressed this idea: 'I want to hear the views of all of those present in the situation so that I can find out what has really happened. I want the class to see how conflicts are resolved constructively' (F98). 


\subsubsection{Organizing a Class Trip (Part 2)}

The subject student teachers were also asked to present a solution to a situation where the class is making an excursion that not everyone will be allowed to go on due to occupancy restrictions. Most subject student teachers wanted to end up with a plan and to discuss it with the tour staff $(58.7 \%)$. Some, in turn, were ready to directly ask the tour staff's opinion on the problem without a plan (12.3\%). The rest of the answers (29.0\%) did not show any social interaction with other people on the trip. One suggested solution was to change the destination or to divide the class into groups and then make several visits.

In addition to the solutions presented above, other commonly occurring issues were noted in the answers. For example, one-third of the subject student teachers also had an alternative plan. Usually, the alternative plan was ready to be implemented if the first plan with the tour staff did not work. Some subject student teachers questioned the controversial situation (11. 6\%). The number of resources was also mentioned $(10.1 \%)$. For many of them, it was important that every student has the possibility to join the excursion. In several answers, this was emphasized separately in addition to the solution (18.8\%). Excluding other students was a less common option, either directly $(2.9 \%)$ or as a fallback option $(5.1 \%)$.

\subsubsection{Responding to Different Statements (Part 3)}

The subject student teachers were given five statements that they had to mark as true or false and justify their answers (see Table 1). The statements were: 1 . Continuous economic growth is possible; 2 . Economic equality will be achieved between the welfare states and developing countries in the next few years; 3 . The school day should start at eight o'clock; 4 . Finland can afford to cut forests at the current rate; and 5 . The traffic rules should always be followed. The subject student teachers substantiated their statements in different ways, and these were divided based on opponents into strong opinions, statements, beliefs, and uncertain opinions. Most answers were statements without strong expressions of feeling. Strong opinions were more represented in the answer option (True/False) that was more common amongst the other subject student teachers. An exception to this was statement 4, where strong opinions appeared in both true and false answers. 
Table 1. Subject student teachers' answers to the statements and the certainty of the answers. The statements were: 1 . Continuous economic growth is possible; 2. Economic equality will be achieved between the welfare states and developing countries in the next few years; 3 . The school day should start at eight o'clock; 4. Finland can afford to cut forests at the current rate; and 5. The traffic rules should always be followed.

\begin{tabular}{|c|c|c|c|c|c|c|}
\hline & $\%$ & $\begin{array}{c}\text { Statement } \\
1\end{array}$ & $\begin{array}{l}\text { Statement } \\
2\end{array}$ & $\begin{array}{c}\text { Statement } \\
3\end{array}$ & $\begin{array}{c}\text { Statement } \\
4\end{array}$ & $\begin{array}{c}\text { Statement } \\
5\end{array}$ \\
\hline & True & 18.84 & 0.72 & 18.84 & 31.88 & 71.74 \\
\hline & False & 81.16 & 98.55 & 80.43 & 65.22 & 27.54 \\
\hline & No answer & 0 & 0.72 & 0.72 & 2.90 & 0.72 \\
\hline & In total & 100 & 100 & 100 & 100 & 100 \\
\hline Answer certainty & Strong opinion & 0 & 0 & 0.00 & 2.27 & 11.11 \\
\hline \multirow[t]{3}{*}{ (True) } & Statement & 61.54 & 100 & 69.23 & 54.55 & 62.63 \\
\hline & Belief & 7.69 & 0 & 23.08 & 22.73 & 5.05 \\
\hline & Uncertain opinion & 7.69 & 0 & 0 & 9.09 & 5.05 \\
\hline \multirow{4}{*}{$\begin{array}{c}\text { Answer certainty } \\
\text { (False) }\end{array}$} & Strong opinion & 5.36 & 3.68 & 3.60 & 3.33 & 0 \\
\hline & Statement & 68.75 & 51.47 & 67.57 & 61.11 & 81.58 \\
\hline & Belief & 12.50 & 31.62 & 18.92 & 7.78 & 13.16 \\
\hline & Uncertain opinion & 1.79 & 2.21 & 3.60 & 14.44 & 0 \\
\hline
\end{tabular}

5.4. The Subject Student Teachers' Likelihood to Influence the School Culture with Respect to $S D(R Q 4)$

The fourth research question was designed to determine the subject student teachers' interest in influencing school culture in the context of SD. About $70 \%$ of the subject student teachers were interested, and nearly $25 \%$ of them were very interested in participating in the school's culture of SD (Figure 5). More specifically, they preferably wanted to influence bullying prevention in the school environment (Figures 6 and 7). In addition, the well-being of school staff and students, as well as student welfare, was seen as a meaningful part of influence.

In general, the subject student teachers saw bullying and inequality (53.4\%) to be major problems in the school community (Figure 6). Other problems for students $(18.1 \%)$ and teachers $(16.4 \%)$ in the school community were also central to this. They were concerned also about teacher exhaustion, the poor work atmosphere, and lack of collaboration skills amongst teachers. They argued that teachers today are being overly pressured to use digital devices and implement other innovations, and that this could result in their relationships with colleagues being poor. They also 
expressed concern about students' exhaustion, motivation problems, and lack of skills in areas such as civility, cooperation, and language skills (Finnish as a second language = S2 students). They also mentioned electronic devices and their harmful effects.

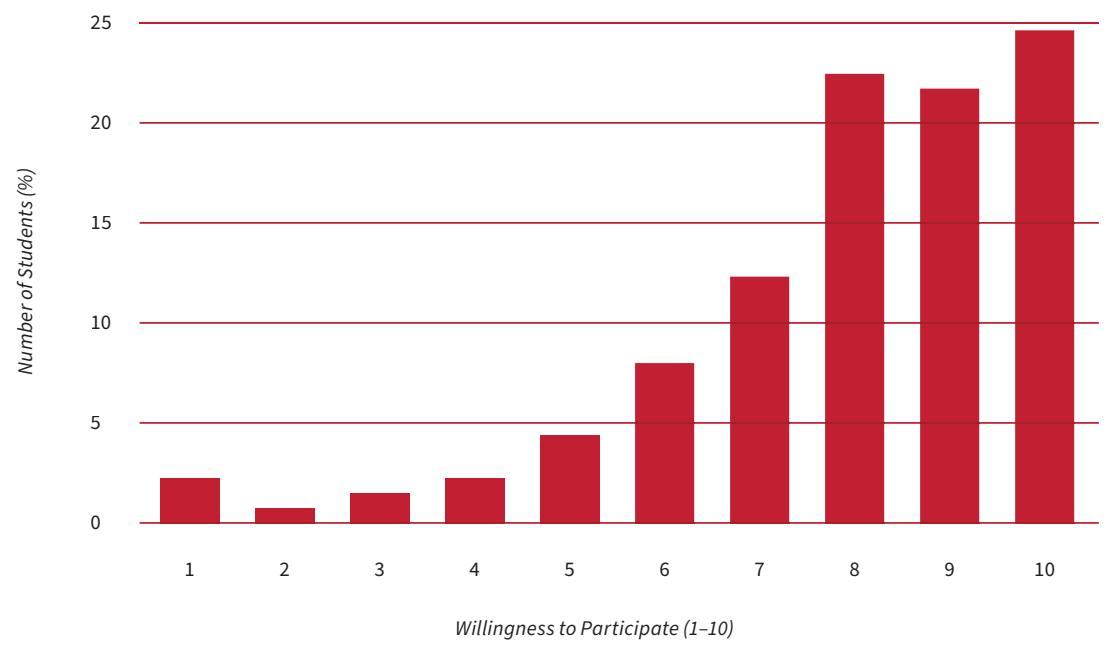

Figure 5. The subject student teachers' willingness to participate in the development of the school culture regarding sustainable development (SD).

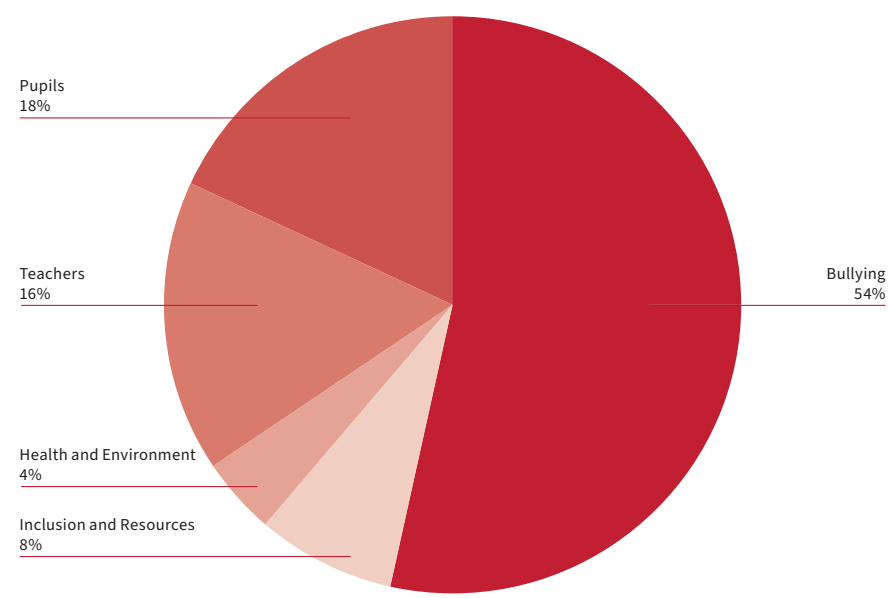

Figure 6. Problems of the school community mentioned by the subject student teachers in the open-ended questions (\%). The teachers' section included both teacher well-being and lack of collaboration skills, and the pupils' section included well-being, motivation, and scholarship. 
Inefficiencies in inclusion and integration were mentioned several times $(7.8 \%)$, and they were usually linked to the lack of resources in the school. Class sizes were considered too large for teachers to control. Noted health and environmental problems $(4.3 \%)$ included indoor air problems, loss of food, lack of recycling, and laziness in implementing sustainable development. The questionnaire also asked them to describe a multidisciplinary approach to any solution; however, this did not suit many of the stated problem situations. All the same, even in other problems (for example, bullying), multidisciplinary teaching methods were often considered ineffective.

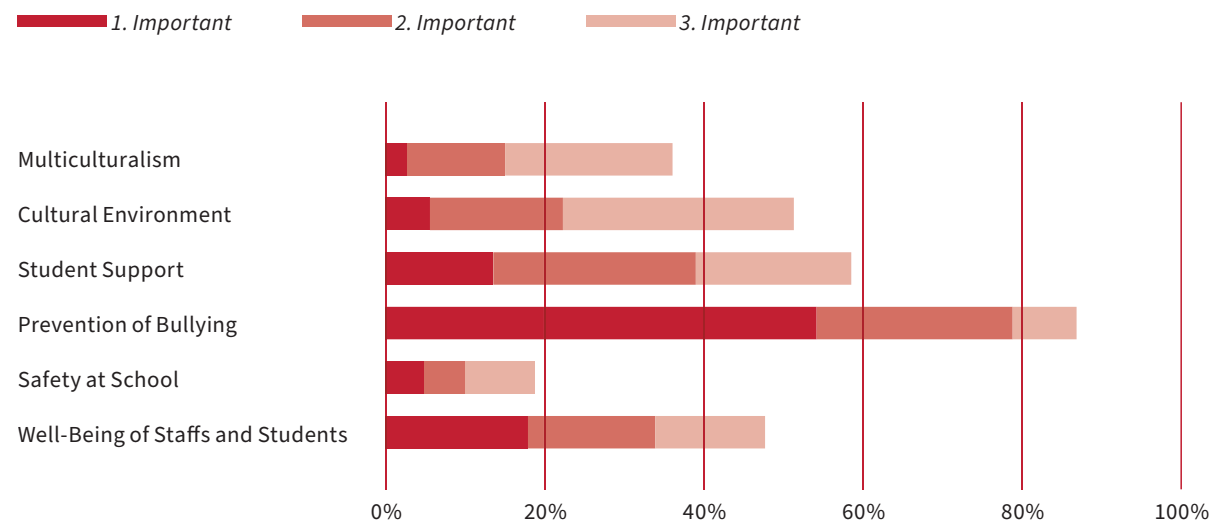

Figure 7. The level of importance concerning the subject student teachers' willingness to participate in the development of different school culture subjects regarding SD. This was a multiple-choice question, and the subject student teachers had to choose three answers in order of their importance based on the available options. The options were based on Saloranta (2017) social and cultural sustainability themes.

The subject student teachers wanted to influence the same things they saw as a problem in the school environment. They thought that teachers' decisions were primarily applied to equality, the creation of a good atmosphere, security, and the well-being of the students (Figure 7). They wanted to make the school environment a pleasant place where everyone had the same rights and opportunities. They felt that bullying weakens this possibility the most. They also shared personal experiences of bullying, as one subject student teacher wrote: 'I think bullying is the worst thing a student can experience. Bullying on the Internet is a difficult and "invisible" dilemma that deserves greater attention for its possible eradication' (F6). The subject student teacher's willingness to participate in the development of the school culture is 9 
(Figure 5), and they had chosen "Prevention of Bullying" as the most important subject in which to participate (Figure 7).

In addition, the teachers wanted to influence current problems and provide students with opportunities for developing civility and spiritual growth. The importance of the environment and the students' interests were also reflected in the answers. However, the subject student teachers themselves were not very interested in participating in school physical safety.

\section{Discussion}

The subject student teachers were aware of the existence of SDE in school, in general. Global, regional, and local environmental problems were identified as well as some methods to solve these problems. These results were in keeping with the Finnish policymaking documents and strategies (Ministry of Education 2006; Ministry of the Environment 2007; Finnish National Board of Education 2013, 2014). However, they did not see social disadvantages as environmental problems as much as ecological and economic disadvantages.

In earlier studies, it has been shown that the young pupils and students highlighted and brought up littering as a major environmental problem (e.g., Loughland et al. 2002; Palmberg and Kuru 2000; Ercan 2011; Yli-Panula et al. 2019) which was also the case in this study. The results of this study showed that the subject student teachers were concerned about littering at the local level. The results also showed that the Finnish subject student teachers were aware of the adverse effects of climate change, especially at the global level. However, for example, no swamps were mentioned in the answers, although this has been the case in media. Climate change is a diverse socio-scientific issue (Sadler 2011), and it is regarded one of the biggest health threats of the 21st century (Watts et al. 2015; Robbins 2015; McIver et al. 2015). In the article of Yang et al. (2018), Chinese medical students were found to be less likely to adopt a global view of the impacts of climate change. Climate change as a topic-specific epistemic belief has been shown to be very likely culturally bound (cf. Bråten et al. 2009).

The subject student teachers in this study were not very much aware of social disadvantages. They believed that environmental problems can be solved both by social means, such as international cooperation, politics, and education, and also by sustainable consumption and reasonable construction (cf. Ercan 2011). In their opinion, environmental problem-solvers include schools, politicians, and large companies, and they stated that their responsibility for solving environmental problems is greater at the local than at the global level. 
With respect to the school community, the subject student teachers attached great importance to student equality and well-being. This was reflected in their practices in the school community and their interest in the influence of school culture. Therefore, they saw bullying as one of the biggest problems in the school community, and they wanted to contribute to its prevention. This result differs from previous research results, for example, that classroom cohesion and self-efficacy in social conflicts have been shown to be directly associated with students' willingness to intervene in bullying situations (cf. Wachs et al. 2018), and it is important to also take this into account in SDE. The subject student teachers were also concerned about the well-being of teachers and students within a demanding working community. In general, they were interested in the impact of SD. These results support those of previous research (Andersson et al. 2013). Amongst other things, they wanted to increase vegetarian meal opportunities in schools and reduce food waste. They assessed their social capacity as generally being good, but they also often wanted to make their own decisions, ignoring social help or opinions. Thus, based on the results of the study, it seems that it is important that teacher educators see, according to Bronfenbrenner's ecological environmental theory (1994), the starting points for SDE from an individual perspective taking into account the student teachers' ideas and views when the goal is promoting equity, improving quality of life and well-being, sustaining natural resources, and protecting health.

The reliability of this study is based on methodological triangulation: a mixed method approach was used, and several type of questions (e.g., open-ended and closed questions) were used in each research question. The reliability is also supported by the four researchers who participated in all phases of the study, for example, coming to an agreement on the analysis concerning the subject student teachers' answers (Lincoln and Cuba 1985). The reliability of the study is also supported by the earlier findings of other researchers. However, this study also has limitations. Although the number of participants is quite small, it still gives an overview of the Finnish subject student teachers' views of their social competencies.

\section{Conclusion and Implications}

According to the Finnish subject student teachers' views, they are concerned about core environmental problems on the local (e.g., littering, lack of recycling, people's well-being), regional (e.g., the state of the Baltic Sea), and global (e.g., climate change, human rights) levels. It is evident that they are interested in SD decision-making in school, and they value equality and the mental well-being of people. They expressed the belief that environmental problems can be solved both 
by social means, such as international cooperation, politics, and education, as well as by sustainable consumption and reasonable construction. Thus, they believe we can achieve SDG4 and improve the quality of education; however, the authors stress the need to strengthen teacher training in social skills.

Author Contributions: Conceptualization, E.Y.-P., E.J., S.V., P.T.; methodology, E.Y.-P., E.J., S.V., P.T.; validation, E.Y.-P., E.J., S.V., P.T.; formal analysis, E.Y.-P., E.J., S.V.; investigation, E.Y.-P., E.J., S.V., P.T.; resources, E.Y.-P., E.J., S.V., P.T.; data curation, E.Y.-P., E.J., S.V.; writing—original draft preparation, E.Y.-P., E.J., S.V., P.T.; writing — review and editing, E.Y.-P.; visualization, E.Y.-P., S.V.; supervision, E.Y.-P., E.J.; project administration, E.Y.-P.; funding acquisition, E.Y.-P., P.T.

Funding: This research was funded by the Finnish Ministry of Education and Culture, OVET project.

Conflicts of Interest: The authors declare no conflict of interest.

\section{References}

Aarresaari. 2017. Career Services Network of Finnish Universities. Master's dissertation. Available online: https://www.aarresaari.net/career_monitoring/masters_degree_career_ monitoring (accessed on 16 September 2019).

Andersson, Klas, Sverker C. Jagers, Annika Lindskog, and Johan Martinsson. 2013. Learning for the Future? Effects of Education for Sustainable Development (ESD) on Teacher Education Students. Sustainability 5: 5135-52. [CrossRef]

Blömeke, Sigrid, Jan-Eric Gustafsson, and Richard J. Shavelson. 2015. Beyond dichotomies: Competence Viewed as a Continuum, Zeitschrift für Psychologie 223: 3-13. [CrossRef]

Bråten, Ivar, Laura Gil, Helge I. Strømsø, and Eduardo Vidal-Abarca. 2009. Personal Epistemology across Cultures: Exploring Norwegian and Spanish University Students' Epistemic Beliefs about Climate Change. Social Psychology of Education 12: 529-60. [CrossRef]

Bronfenbrenner, Urie. 1994. Ecological Models of Human Development. In International Encyclopedia of Education, 3(2). Oxford: Elsevier.

Brundiers, Katja, and Arnim Wiek. 2017. Beyond Interpersonal Competence: Teaching and Learning Professional Skills in Sustainability. Education Sciences 7: 39. [CrossRef]

Ercan, Feride. 2011. Student Perceptions and Solutions about the Matters of Environment. Procedia Social and Behavioral Sciences 19: 450-52. [CrossRef]

Finlex. 2001. Valtioneuvoston Asetus Perusopetuslaissa Tarkoitetun Opetuksen Valtakunnallisista Tavoitteista ja Perusopetuksen Tuntijaosta [Government Decree of the Basic Education Act]. Available online: http://www.finlex.fi/fi/laki/alkup/2001/20011435 (accessed on 19th August 2019).

Finnish National Board of Education. 2013. The Finnish National Core Curriculum for Upper Secondary School. Helsinki: The National Board of Education. 
Finnish National Board of Education. 2014. The Finnish National Core Curriculum for Basic education. Helsinki: The National Board of Education.

Fletcher, Brown. 2000. Characterizing Effective Environmental Education and Its Impact on Preservice Students' Environmental Attitudes. Journal of Elementary Science Education 12: 33-39.

Jennings, Patricia A., and Mark T. Greenberg. 2009. The Prosocial Classroom: Teacher Social and Emotional Competence in Relation to Student and Classroom Outcomes. Review of Educational Research 79: 491-525. [CrossRef]

Korppas, Marjaana. 2008. Aineenopettajakoulutuksen nykytila ja kehittämistarpeet, [Current State and Development Needs of Subject Teacher Education, AINO project report 2008.] AINO-hankkeen loppuraportti 2008. Turku: University of Turku, Department of Teacher Education.

Lincoln, Yvonna S., and Egon G. Cuba. 1985. Naturalistic Inquiry. Beverly Hills: Sage.

Loughland, Tony, Anna Reid, and Peter Petocz. 2002. Young People's Conceptions of Environment; A phenomegraphic Analyses. Environmental Education Research 8: 187-17. [CrossRef]

McIver, Lachlan, Rokho Kim, Alistair Woodward, Simon Hales, Jeffery Spickett, Dianne Katscherian, Masahiro Hashizume, Yasushi Honda, Ho Kim, Steven Iddings, and et al. 2015. Health Impacts of Climate Change in Pacific Island Countries: A Regional Assessment of Vulnerabilities and Adaptation Priorities. Environmental Health Perspectives 124: 1707-14. [CrossRef] [PubMed]

Metsäpelto, Riitta-Leena, Anna-Maija Poikkeus, Mirva Heikkilä, Kirsi Heikkinen-Jokilahti, Jukka Husu, Anu Laine, Kristiina Lappalainen, Marko Lähteenmäki, Mirja-Maija Mikkilä-Erdmann, and Anu Warinowski. 2020. Conceptual framework of teaching quality: A Multidimensional Adapted Process Model of Teaching. Available online: psyarxiv.com/52tcv (accessed on 25 February 2020).

Ministry of Education. 2006. Sustainable Development in Education; Implementation of Baltic 21E Programme and Finnish Strategy for the Decade of Education for Sustainable Development (2005-2014). Reports of the Ministry of Education, Report 2006:6. Helsinki: Ministry of Education.

Ministry of the Environment. 2007. Saving Nature for People: National Strategy and Action Plan for the Conservation and Sustainable use of Biodiversity in Finland 2006-16. Helsinki: Ministry of the Environment.

Nisiforou, Olympia, and Alexandros G. Charalambides. 2012. Assessing Undergraduate University Students' Level of Knowledge, Attitudes and Behaviour Towards Biodiversity: A Case Study in Cyprus. International Journal of Science Education 34: 1027-51. [CrossRef]

Palmberg, Irmeli, and Jari Kuru. 2000. Outdoor Activities as a Basis for Environmental Responsibility. The Journal of Environmental education 31: 32-46. [CrossRef] 
Robbins, Anthony. 2015. Health Consequences of Climate Change Interventions. Lancet 386: 1819. [CrossRef]

Rychen, Dominique S., and Laura H. Salganik. 2003. A Holistic Model of Competence. In Defining and Selecting Key Competencies. Edited by Dominique Simone Rychen and Laura Hersh Salganik. Seattle: Hogrefe \& Huber, pp. 41-62.

Sadler, Troy D. 2011. Situating Socio-Scientific Issues in the Classroom as a Means of Achieving Goals of Science Education. In Socio-Scientific Issues in the Classroom: Teaching, Learning and Research. Edited by Troy D. Sadler. New York: Springer, pp. 1-9.

Saloranta, Seppo. 2017. Koulun Toimintakulttuurin Merkitys Kestävän Kehityksen Kasvatuksen Toteuttamisessa Perusopetuksen Vuosiluokkien 1-6 Kouluissa. [The Importance of a School's Culture in Implementing Education for Sustainable Development in Basic Education Grades 1-6 Schools]. Ph.D. dissertation, University of Helsinki, Helsinki, Finland, September 2214.

Silvera, Collette A. 2017. Understanding the Symbols and History of School Culture in an Alternative School: Community, Character, Commitment, and Chasm. Ph.D. dissertation, Carson-Newman University, Jefferson City, TN, USA, May 29.

Stolp, Stephen. 1994. Leadership for School Culture. ERIC Digest 91 UNESCO 2017. Education for Sustainable Development Goals: Learning Objectives. Education 2030. Paris, UNESCO. Available online: https://unesdoc.unesco.org/ark:/48223/pf0000247444 (accessed on 5th September 2019).

UNESCO. 2017. Education for Sustainable Development Goals: Learning Objectives. Available online: https://unesdoc.unesco.org/ark:/48223/pf0000247444 (accessed on 5th September 2019).

United Nations. 2015. Transforming our world: the 2030 Agenda for Sustainable Development. New York: General Assembly, A/70/L.1.

Velazquez, Fransisco D.C., and Fernando L. Rivas. 2020. Education for Sustainable Development in STEM (Technical Drawing): Learning Approach and Method for SDG 11 in Classrooms. Sustainability 12: 2706. [CrossRef]

Wachs, Sebastian, Ludwig Bilz, Saskia M. Fischer, Wilfried Schubarth, and Michelle F. Wright. 2018. Students' Willingness to Intervene in Bullying: Direct and Indirect Associations with Classroom Cohesion and Self-Efficacy. International Journal of Environmental Research and Public Health 15: 2577. [CrossRef] [PubMed]

Watts, Nick, W. Neil Adger, Paolo Agnolucci, Jason Blackstock, Peter Byass, Wenjia Cai, Sarah Chaytor, Tim Colbourn, Mat Collins, Adam Cooper, and et al. 2015. Health and Climate Change: Policy Responses to Protect Public Health. Lancet 386: 1861-914. [CrossRef]

Wolff, Lili-Ann, Pia Sjöblom, Maria Hofman-Bergholm, and Irmeli Palmberg. 2017. High performance education fails in sustainability? - A reflection on Finnish primary teacher education. Education Sciences. vol. 7, no. 1, 32. [CrossRef] 
Yang, Lianping, Wenmin Liao, Chaojie Liu, Na Zhang, Shuang Zhong, and Cunrui Huang. 2018. Associations between Knowledge of the Causes and Perceived Impacts of Climate Change: A Cross-Sectional Survey of Medical, Public Health and Nursing Students in Universities in China. International Journal of Environmental Research and Public Health 15: 2650. [CrossRef] [PubMed]

Yli-Panula, Eija, Eila Jeronen, and Gabriela Rodriguez-Aflecht. 2019. Nature Is Something We Can't Replace: Mexican Students' Views of the Landscape They Want to Conserve. In Education Sciences. vol. 10. [CrossRef]

(C) 2021 by the author. Licensee MDPI, Basel, Switzerland. This article is an open access article distributed under the terms and conditions of the Creative Commons Attribution (CC BY) license (http://creativecommons.org/licenses/by/4.0/). 



\title{
4E-
}

\section{Start for Sustainable Development: Ecological Footprint}

\author{
Hamdi KARAKAŞ
}

\section{Introduction}

The recognition of environmental problems on a global scale and the adoption of international measures took place in 1972 with the Human and Environmental Conference held in Stockholm. After that, UNESCO issued an "International Environmental Education Program" on 22 October 1975 and published a declaration called the Charter of Belgrade. In 1977, the "Intergovernmental Environmental Education Conference" was held in Tbilisi and the Tbilisi Declaration 1977 was published. The sentence, "Environmental Education should contribute to the awareness of the economic and ecological interdependence of the modern world in order to create a spirit of international responsibility and solidarity" was used in the final declaration of the conference in Tbilisi (Tbilisi Declaration 1977, p. 2). As a result of these three conferences, it was emphasized that defending and improving the environment is an inevitable task for humanity and that environmental education is a must for the generations currently living and will continue to live on earth. The Rio Summit in 1992 made significant contributions to Environmental Education. In this meeting, it was emphasized that environment and development could not be considered separately and that any development should be sustainable development (Misar 2000).

It has become inevitable that efforts to raise environmental awareness and environmental problems in a global sense should be made available at all levels of education levels starting from pre-school period through environmental education programs (Yücel and Özkan 2013). With environmental education, the aim is to help individuals develop positive attitudes towards the environment, thus leading them to sustainability by shaping their lifestyles with environmentally conscious behavior (Meyer 2004). This is because sustainability envisages increasing the biologically productive areas, ensuring their self-renewal and the maintenance of renewal capacities (Y1ldız and Selvi 2015). Sustainability includes environmental-economic trade-offs from choices that affect social-ecological systems today and in the future, and it reflects a dilemma for us (Chapin et al. 2011). Therefore, sustainable development has become a necessity for a livable world. Sustainable development means 
continuing without harming the economy (Taylor et al. 2007). While sustainable development is evaluated from an economic point of view, it aims not to ignore the environmental dimension and to use resources in a balanced and sparing manner by considering the next generations (Harris 2000). In the development policies to be implemented, it is important to protect ecological processes, sustainable use of resources and the conservation of genetic diversity (Soussan 1992). From this point of view, the aim of environmental education should be to provide awareness that will ensure sustainable development. International Union for Conservation of Nature (IUCN) emphasizes that individuals' attitudes towards sustainable environment should be replaced by education programs (IUCN 1991); The Rio Summit agenda 21 report (United Nations Conference on Environment and Development (UNCED)) states that the environmental value, attitude, skills, behavior and ethical awareness necessary for sustainable development are acquired through education (UNCED 1992). The 17th United Nations Sustainable Development Goals (SDGs) was published in 2015 as a framework program for the necessity of integrate the environment in all aspects of sustainable development (SDGs 2015). Among these goals, SDG 4 has been identified as "Quality Education" and emphasized that the education to be provided to the students in schools from an early age is a powerful tool for creating sustainable and flexible societies. Within the framework of the same objective, Quality Education is critical for promoting sustainable development, addressing environmental and development issues of the people and countries and increasing their capacity to create green sectors. Thus, with the sustainable development, the interests of future generations will be protected, the interests of today's people will be ensured, and a balance will be established (Collin 2011).

A modern understanding of environmental education should be considered, which addresses environmental elements with a holistic and sociocultural approach, emphasizes sustainability, and encourages individuals to act (Sauvé 2005). Pooley and O'Connor (2000) emphasized the necessity of activities to help students develop positive attitudes towards the environment as well as providing theoretical knowledge to the students, determined that the use of different methods and techniques is important in creating lasting behavior. The concept of "Ecological Footprint" for students in terms of environmental education and sustainability and awareness about this concept is one of the prominent activities. According to Wackernagel and Rees (1996), ecological footprint can be used as a method in games and school projects to enable sustainable lifestyle activities to realize concrete local practices such as mathematics, biology and physics taught 
simultaneously. The concept of ecological footprint can be combined with in-school and out-of-school educational activities.

Based on this point, it was deemed important by the researcher to measure the relationship between sustainable use of resources and ecological footprint and the aim was to work with students at elementary level (primary school 1st, 2nd, 3rd and 4th grade; secondary school 5th, 6th, 7th and 8th grade) that form the basis of the educational process. The students in the elementary education process receive the information about Life Science, Science and Social Studies courses and the theoretical information about environmental education directly in this process, and they can implicitly perform activities for environmental education through other courses (MoNE (2017a, 2017b, 2017c)). When the related studies are examined, the lack of a study examining the concept of ecological footprint and student attitudes towards sustainable development together makes this research valuable. At the same time, this study is important in terms of measuring the ecological footprints of this group of students who will use the resources in the future and to determine their attitudes towards sustainable development and to determine the level of these students in order to provide a prediction for the teachers who are the practitioners of the educational process. Thus, the results of this study can contribute to the development of ecological footprint awareness in educational environments and increase the number of studies in this field. From this point of view, in this study, it was aimed to investigate the relationship between primary school students' ecological footprint average scores and their attitudes towards sustainable development.

\section{Theoretical Part}

\subsection{Destruction of Natural Resources}

Human beings obtain many elements that will help them continue their lives from the environment and the natural resources offered by the environment. When these natural resources are used in reasonable amounts, the world can renew itself and the natural cycle can be re-formed. While the changes that people made on natural life did not pose a threat to the ecosystem until the industrial revolution, unconscious interventions with nature led to the disruption of the natural balance in the ecosystem and ecological problems on a global scale (Özbuğutu et al. 2014). Very important reasons, such as scientific and technological developments in the last century, overpopulation, the desire to use and consume more, urbanization played an active role in this issue, natural resources rapidly depleted, the interaction between living and non-living beings was disrupted and natural life changed. This change and careless use of resources brought about some 
complications, also called "environmental problems" such as global climate change, perforation of ozone layer, destruction of forests, erosion, air, soil, water pollution, reduction of biological diversity, radioactive pollution and acid rain (Borden 1985; Sam et al. 2010). Developing countries with a relatively poor and vulnerable population are primarily affected by the consequences of such environmental changes (Rudolpha and Figge 2017). While these environmental problems are felt in small dimensions and at local levels in the middle of the last century, they are now increasingly being addressed globally (Özdemir et al. 2004). However, the point that should be kept in mind is that the threat posed by the problems will not only be the problem of the present day, it will also cause the needs of the next generation to be borrowed, and what they will need will be used up.

With the improvements in technology, people strive to dominate nature and strive to make their lives easier. On the other hand, governments aim to progress in every field so that they can provide a better life for the citizens and they use all natural resources as a prominent input. Thus, rapid economic growth and development is seen as the basic requirement for all states. Humankind has been thinking that everything can be taken and consumed, forests as a supply of paper and timber; seas as a source of fish and energy; plants and animals as sources of food and space as an endless source of resources to be conquered (Aydın and Aykaç 2016). However, the survival of human beings can only be ensured by the resources of the world, which have been greatly changed by humans themselves (Reece et al. 2013). Unfortunately, these resources are being used extensively today, and serious environmental disasters such as air, soil, water pollution, hunger, drought and the destruction of forests are threatening human life. However, humans giving up excessive consumption habits and gaining positive behaviors towards the environment will ensure that resources are not used more than necessary. Thus, the amount of pollution and waste in our world can decrease, environmental balance can be maintained, global climate change can slow down and the pressure on biodiversity can be reduced (EPA (1999)).

\subsection{Ecological Footprint}

Mathis Wackernagel and William Rees first introduced the concept of ecological footprint. Their goal was to find out how long the humankind could continue by taking away from the nature and leaving only waste and how long the resources in the world could withstand this situation (Wackernagel and Rees 1996). Ecological footprint is a method created to calculate the burden of a certain population for the nature in which they are located (Huiqin and Linchun 2011). The concept of ecological footprint means the biologically fertile soil and water area needed to re-produce 
the resources consumed by an individual, community, or activity with existing technology and resource management and to eliminate the waste it creates. Thus, the ecological footprint measures how quickly human activities are consuming the resources of nature and often presents us with biological capacity and the renewal capacity of nature (Bastianoni et al. 2012; Peng et al. 2018). In its simplest form, the formula "Ecological footprint = Consumption $x$ Required production area" is used to make ecological footprint calculations. According to the ecological footprint estimates, it is reported that it is used as a way to estimate the effects of human beings on nature and that approximately 2 hectares of land is needed per person (Reece et al. 2013; Cunningham and Cunningham 2018). Ecological Footprint is calculated according to six different components: carbon footprint, agricultural land footprint, forest footprint, grassland footprint, built area footprint, fishing area footprint and is expressed with the phrase "global hectare" (gha) (WWF (2012)). These components are, briefly:

- Carbon Retention Footprint: Calculation of the forest area required to capture emissions from fossil fuel consumption, land use changes and chemical processes, as well as $\mathrm{CO} 2$ emissions retained by the oceans.

- Agricultural Footprint: Calculation of the area used for food and fiber, animal feed, oil crops and rubber production for human consumption.

- Forest Footprint: Calculation of the forest area required to cover the amount of timber, pulp, wood products and firewood consumed.

- Grassland Footprint: Calculation of the area of livestock for meat, milk, leather and wool products.

- Built Area Footprint: Calculation of the area covered by infrastructure and superstructure for meeting human needs including housing, transportation, industrial buildings and power plants.

- Fishing Area Footprint: Calculation of the marine and freshwater area required to supply consumed fish and seafood (WWF 2012).

The ecological footprint has been developed to measure the impact of human activities on ecosystems. With the ecological footprint calculation, it is possible to measure the land and sea area needed to regenerate the natural resources consumed by a human being. To explain this with a simpler example, a person who consumes one bread ( $300 \mathrm{~g})$ a day, the calculations aim to ascertain how much area should be cultivated for 120 kilograms of bread for that person to eat per year, how much area should be planted for the cotton in that person's clothes, how big of an area is the water that that person drinks is supplied from, etc. (Coşkun and Sarıkaya 2014). Thus, 
ecological footprint measurements are made to obtain nutrients, produce resources, generate energy, eliminate waste and reduce the amount of carbon dioxide increased by photosynthesis through the use of fossil fuels (Keleş et al. 2008). According to the WWF (2018) report, the ecological footprint of the US citizen was determined to be equal to the footprints of 43 African citizens. Moreover, UAE, Qatar, Denmark, USA, Canada, Kuwait and Estonia are among the top 10 countries with the largest ecological footprint. It can be estimated that there is a relationship between ecological footprint and economic development and that ecological footprints of consumption in developed countries have increased. The most important reasons for this situation are the unsustainable consumption behaviors, high resource wastage and carbon emission increases caused by industrialization (Koru 2012).

The growth of the ecological footprint determined by the provision in productive ecosystems such as food, housing area, transportation and amount of waste consumed by the society and/or individual results in the destruction of biological resources (Aklll et al. 2008). From this perspective, the ecological footprint refers to the sustainability relationship between the rate of human consumption of Earth's resources and the degree of healthy or unhealthy ecosystems. At the same time, it is a concept that brings up questions such as what is the share of people in environmental problems and "what can I do?" (Kaypak 2013). Since the ecological footprint reveals the relationship between natural resource supply and demand, it provides a scientific basis for recognizing imbalances and generating solutions (Günal 2018). The ecological footprint focuses more on consumption and gives clues about the damage that people create in nature. In this respect, it is considered that the calculation of ecological footprint reveals the dimensions of the pressure on ecosystem and has an important role in the development of ecological awareness and ecological consciousness. With the awareness of the ecological footprint, the pressure exerted by the consumer society on the planet can be reduced and the growing ecological footprint can be scaled down.

\section{Aim of the Study}

The aim of this study is to investigate the relationship between elementary school students' mean ecological footprint scores and their attitudes towards sustainable development. For this purpose, the following sub-objectives were sought:

1. What are the mean ecological footprints of elementary school students?

1.1. Do the ecological footprint mean scores of elementary school students differ significantly according to gender, location and type of school? 
2. What are the mean attitude scores of elementary school students towards sustainable development?

2.1. Do the mean scores of sustainable development attitude of elementary school students differ significantly according to gender, place of residence and type of school?

3. Is there a relationship between the mean scores of ecological footprints of elementary school students and the mean scores of attitude towards sustainable development?

\section{Materials and Methods}

\subsection{Relational Survey Model}

In this research, the relational survey model, a quantitative research method, is used. An existing situation or phenomenon in the survey model is the approach that is tried to be described as it is. When conducting survey research, the researcher takes a sample from the population he wants to work with and asks survey subjects one or more questions about attitudes, perceptions, or behaviors (Stockemer 2019). In relational screening, the aim is to learn the change of more than one variable together and how it occurs, if there is any change. Starting from the most probable solution, these relationships are tested (Yıldırım and Şimşek 2013). In this context, the relationship between the ecological footprint mean scores of elementary school students and their attitudes towards sustainable development was described and interpreted.

\subsection{Study Group}

Elementary school students (primary school 1st, 2nd, 3rd and 4th grade; secondary school 5th, 6th, 7th and 8th grade) participated in this study. Primary school students are between aged 6-9; middle school students are aged 10-13. Maximum diversity sampling method, one of the purposeful sampling methods, was used to determine the study group. With maximum diversity sampling, a relatively smaller study group is created, and it is aimed that this study group reflects the diversity of individuals who may be part of the problem to the maximum extent (Yıldırım and Şimşek 2013). Thus, it is ensured that the sample group reflects the universe well. In this process, the researcher tried to select the sample group that could best reflect the elementary school student population and the data were collected in the second semester of the 2018-2019 academic year. The researcher contacted different elementary schools from three different regions of the country 
(east, middle and west) and made appointment in advance to apply the data collection tools. The researcher went to the schools that accepted the appointment, informed the students on how the data collection tools would be answered and gave the students 20 minutes to answer the scale questions. As a result of data collection, 210 elementary school students from three different regions of the country (east, middle and west) were reached directly. Regarding the 210 students, the fact that they live in different parts of the country, reside in different settlements and study in different grade is thought to have a structure that can reflect the elementary student profile in the country (Table 1). Thus, maximum diversity was achieved.

Table 1. Characteristics of elementary school students participating in the research.

\begin{tabular}{|c|c|c|c|}
\hline Features of The Working Group & & f & $\%$ \\
\hline \multicolumn{4}{|l|}{ - Gender } \\
\hline Female & & 114 & 54.3 \\
\hline \multirow[t]{2}{*}{ Male } & & 96 & 45.7 \\
\hline & Total & 210 & 100 \\
\hline \multicolumn{4}{|l|}{ - Location } \\
\hline City Centre & & 111 & 52.9 \\
\hline \multirow[t]{2}{*}{ Countryside (District, Town, Village) } & & 99 & 47.1 \\
\hline & Total & 210 & 100 \\
\hline \multicolumn{4}{|l|}{ - Type of School } \\
\hline Primary School ${ }^{1}$ (2nd-3rd-4th grade) & & 76 & 36.2 \\
\hline \multirow[t]{2}{*}{ Secondary School (5th-6th-7th-8th grade) } & & 134 & 63.8 \\
\hline & Total & 210 & 100.0 \\
\hline
\end{tabular}

${ }^{1} 1$ st grade is not included in the sample group because the literacy level is not sufficient.

\subsection{Data Collection Tool}

In this study, "Turkey Specific Ecological Footprint Calculator" developed by Keleş and Özsoy (2010) and "Scale of Attitudes Towards Sustainable Development" developed by Kaya (2013) are used together.

"Turkey Specific Ecological Footprint Calculator" was developed by Keleş and Özsoy (2010) as part of a project. The ecological footprint calculation tool consists of 16 questions in total with 5 questions in the food category, 3 questions in the goods category, 4 questions in the shelter category and 4 questions in the transportation category. The questions are about what foods elementary school students are fed 
with and how often, monthly consumption costs, the size of the house they live in and their expenses, energy consumption options and public transportation preferences and durations. Elementary school students were asked to answer the questions in the ecological footprint calculation tool individually. The ecological footprint calculation tool expresses the number of planets needed in the universe individually by the numerical values of the means taken by elementary school students.

"Attitude Scale for Sustainable Development" was developed by Kaya (2013). The scale has been prepared in a way to reflect the sustainable development attitudes of secondary school students and scale items have been shaped by social, environmental and economic sustainability dimensions of secondary school students. The validity and reliability studies of the scale were conducted by the scale preparer. The 5-point Likert scale consists of 21 items and 3 factors with social, environmental and economic sustainability dimensions. The ratings of these three dimensions are "completely disagree (1)", "disagree (2)", "slightly agree (3)", "agree (4)" and "fully agree (5)." It was suggested that this scale could be applied to different student groups (Kaya 2013). The researcher primarily piloted and tested whether the scale could be applied to elementary school students. This scale pilot was applied to 97 elementary school students who were not included in the research and after the analysis for the pilot application, the main application was started.

\subsection{Data Analysis}

The data collection tool was applied face to face to the elementary school students after the informed by the researcher in compliance with the principle of volunteering and without the name of the student on the forms. All data were randomly ordered and SPSS software was used for statistical analysis of the data. In this research, the data collection tool was applied twice as pilot application and actual application. The purpose of piloting is to test whether the Attitude Scale for Sustainable Development is a reliable data collection tool for elementary school students.

The pilot study was applied to 96 elementary school students who were not included in the sample group, and the obtained data were analyzed and Cronbach's Alpha reliability coefficient was calculated as 0.92 . The reliability coefficient of 0.80 and above indicates that the questionnaire is highly reliable (Büyüköztürk et al. 2012). In this context, it was decided that the scale could be applied to elementary school students, no changes were made on the data collection tool and the actual implementation was started. 
In actual practice, this scale was applied to 210 elementary school students. The Cashier Meyer Olkin (KMO) value of the scale was 0.73 and the Bartlett Sphericity Test results $\left(\mathrm{x}^{2}:\right.$ 3494.115; sd:210; $\left.p<0.05\right)$ were determined to be significant. This result shows that the data about the scale is suitable for factor analysis. In the actual application, the Cronbach's Alpha reliability coefficient for the whole scale and the reliability results for its sub-dimensions was calculated.

The reliability results of the sub-dimensions of the scale were high and the Cronbach's Alpha reliability coefficient for the whole test was calculated as 0.92 (Table 2) and the scale was considered to be highly reliable (Büyüköztürk et al. 2012).

Table 2. Reliability analysis of sub-dimensions of the scale.

\begin{tabular}{lccc} 
Dimension & Number of Items & Cronbach's Alpha & Reliability \\
Social Dimension & 8 & 0.86 & Extremely Reliable \\
Environmental Dimension & 6 & 0.75 & Highly Reliable \\
Economic Sustainability Dimension & 7 & 0.79 & Highly Reliable \\
The Whole of the Scale & $\mathbf{2 1}$ & $\mathbf{0 . 9 2}$ & Extremely Reliable \\
\hline
\end{tabular}

Kolmogorov-Smirnov and Shapiro-Wilk tests were performed for the normality of data sets applied to elementary school students. Looking at the results obtained from the tests, it was determined that the data were suitable for normal distribution $(p>0.05)$ and the skewness and kurtosis coefficients were in the range of +2 to -2 . At the same time, Levene test was performed for each variable to evaluate the equality of variances and since the data showed normal distribution $(p>0.05)$, a decision was made to use parametric tests in the analysis of the measurements. Percentage, frequency and arithmetic mean were used in the analysis of the mean scores of the ecological footprint and attitude towards sustainable development of elementary school students. In the comparison of these mean scores according to gender, location and type of school, independent groups were analyzed by t-test and the effect size (eta square $\left[\dot{\eta}^{2}\right]$ ) was calculated. Cohen's $d$ formula, which is put forward by Cohen in effect size calculation is taken as a basis. According to Cohen, if the value of Cohen's $d$ is less than 0.2 , the effect size is small; if it is 0.5 , medium and if it is higher than 0.8, the effect size is large (Kılıç 2014). The difference between the mean scores of the subscales of the Sustainable Development Attitude Scale was analyzed by ANOVA test.

The correlation between the ecological footprint mean scores of the elementary school students and the sustainable development attitude mean scores was calculated by correlation analysis and "Pearson Correlation" coefficient was used. The correlation coefficient $(r)$ has a value between -1 and +1 , which means a positive increasing 
relationship as it approaches +1 , a negative increasing relationship as it approaches -1 , and a neutral relation as it approaches 0 and with Sig. (2-tailed) value a significant relationship is interpreted. At the same time, $|\mathrm{r}|<0.30$ is interpreted as a relationship with weak force, $0.30<|\mathrm{r}|<0.70$ is interpreted as medium-strong relationship and $|r|>0.70$ is interpreted as a strong relationship (Büyüköztürk et al. 2012).

\section{Results}

In this study, it was aimed to investigate the relationship between primary school students' ecological footprint average scores and their attitudes towards sustainable development. The findings related to the sub-objectives formed in line with the aims investigated are given below.

\subsection{Findings on the Ecological Footprint Mean of Elementary School Students}

The answers of the elementary school students to the questions in the ecological footprint calculation tool were analyzed and the mean scores of the ecological footprints of elementary school students are calculated.

The mean ecological footprint scores of elementary school students are calculated as 2.11 gha (Table 3). This value indicates that more than two worlds will be needed to meet the needs of elementary school students. Mean ecological footprint scores of elementary school students were compared with independent groups $t$-test according to gender, location and type of school and the results.

Table 3. Ecological footprint mean scores of elementary school students.

\begin{tabular}{cccccc} 
& N & Min. & Max. & Std. & $\overline{\mathbf{X}}$ \\
Mean Ecological Footprint & 210 & 1.38 & 4.13 & 0.54 & 2.11 \\
\hline
\end{tabular}

The difference between the mean scores of ecological footprints of elementary school students was not statistically significant according to gender and location variable $(p>0.05)$, but according to the type of school variable it is statistically significant $(p<0.05)$ (Table 4$)$. The effect size of the difference between the school type variable scores $\left(\dot{\eta}^{2}\right)$ was calculated as 0.42 and this value was determined to be a moderate effect since it was $0.2<$ Cohen's $d<0.8$. The mean scores of ecological footprints of the students in the secondary school education process are lower than the students in the primary education process which was the previous education level. This situation can be interpreted as the education process reducing the mean scores of students' ecological footprint with a moderate effect. 
Table 4. Comparison of mean ecological footprint scores with independent groups $t$-test.

\begin{tabular}{|c|c|c|c|c|c|c|c|}
\hline \multicolumn{2}{|c|}{ Ecological Footprint Mean Scores } & $\mathbf{N}$ & $\overline{\mathbf{X}}$ & Std. & sd & $t$ & $p$ \\
\hline \multirow{2}{*}{ Gender } & Female & 114 & 2.10 & 0.58 & \multirow{2}{*}{208} & \multirow{2}{*}{-0.621} & \multirow{2}{*}{0.193} \\
\hline & Male & 96 & 2.14 & 0.50 & & & \\
\hline \multirow{2}{*}{ Location } & County & 99 & 2.07 & 0.54 & \multirow{2}{*}{208} & \multirow{2}{*}{-1.152} & \multirow{2}{*}{0.339} \\
\hline & City Centre & 111 & 2.16 & 0.55 & & & \\
\hline \multirow[t]{2}{*}{ Type of School } & Primary School & 76 & 2.28 & 0.76 & \multirow{2}{*}{208} & \multirow{2}{*}{3.249} & \multirow{2}{*}{$0.001^{1}$} \\
\hline & Secondary School & 134 & 2.03 & 0.35 & & & \\
\hline
\end{tabular}

${ }^{1} \mathrm{t}(208)=3.249 ; p=0.001 ; \eta^{2}=0.42$

\subsection{The Findings Regarding Elementary School Students' Attitudes Towards Sustainable Development}

The answers of the elementary school students to the questions in the "Attitude Scale for Sustainable Development" were analyzed and the percentages and frequency calculations of the answers were made.

When the answers of elementary school students towards their attitudes towards sustainable development are examined (Appendix A), it is observed that many questions are concentrated in "strongly agree" and "agree" options. However, when some items were examined, it was seen that some items did not reflect the attitudes expected from elementary school students. When the answers to items S.4, S.5, S.7, and S.8, and the social dimension of sustainable development were examined, it was observed that most elementary school students held their interests ahead of society's interests (strongly disagree, disagree, and undecided rates total N:117, 55.7\%); they could not have empathy while evaluating behavior (strongly disagree, disagree, and undecided rates total $\mathrm{N}: 112,53.2 \%$ ); they could not be neutral in evaluating the events (strongly disagree, disagree and undecided rates total N:133, 63.4\%) and that they could say things that would hurt the person they are talking to (absolutely disagree, disagree and undecided rates total N: 119, 56.6\%). When the answers to items C.2, C.5, and the environmental dimensions of sustainable development were examined, it was observed that most elementary school students do not prefer public transportation (strongly disagree, disagree and undecided rates total $\mathrm{N}: 131,62.4 \%$ ) and do not prefer nature-friendly products instead of plastic products (strongly disagree, disagree and undecided rates total N:132, 62.8\%). In Article E.3, which is the Economic Dimension of Sustainable Development, it is seen that most elementary school students do not pay attention to buying surplus products (strongly 
disagree, disagree and undecided rates total $\mathrm{N}: 116,55.3 \%$ ). It can be said by looking at the answers given to these items, that elementary school students may have problems in achieving the expected behaviors through the MoNE (2017a, 2017b, 2017c).

The mean scores of attitude towards sustainable development of elementary school students were calculated together with their sub-dimensions. When the scale mean scores are calculated, elementary school students score between 1 and 5, which means positive attitude as the mean of the scores approaches five.

The mean score of attitude towards sustainable development of elementary school students was calculated as 3.62 (Table 5), since this value is in the range of $3.41<X<4.20$ it covers the "agree" range of points (Kaya 2013). However, the low mean score may indicate that elementary school students do not exhibit the expected sustainable development attitude. The mean scores of elementary school students regarding the subscales of Sustainable Development Attitude Scale were calculated and the difference between the subscales mean scores was analyzed by ANOVA test.

Table 5. Sustainable development attitude mean scores.

\begin{tabular}{lccccc} 
& N & Min. & Max. & Std. & $\overline{\mathbf{X}}$ \\
$\begin{array}{l}\text { Attitude Towards Sustainable } \\
\text { Development Mean Score }\end{array}$ & 210 & 2.00 & 4.61 & 0.72 & 3.62 \\
\hline
\end{tabular}

It is concluded that the mean scores of attitude towards social dimension of sustainable development of elementary school students are lower than the other dimensions and mean scores of economic dimension are higher (Table 6). However, the difference between the mean subscale mean scores was not statistically significant $(p>0.05)$. Sustainable development attitude mean scores of elementary school students were compared with independent groups $t$-test according to gender, location and type of school.

Table 6. Comparison of sustainable development attitude sub-dimensions between mean scores.

\begin{tabular}{lccccccc} 
Sub-Dimension & $\overline{\mathrm{X}}$ & Std. & Assumption Source & Sum of Squares & sd & Mean of Squares & F \\
$\begin{array}{l}\text { Social Dimension } \\
\text { Environmental }\end{array}$ & 3.58 & 0.059 & Inter-group & 0.927 & 1 & 0.464 & 0.742 \\
$\begin{array}{l}\text { Dimension } \\
\text { Economic }\end{array}$ & 3.61 & 0.050 & Intra-group & 391.738 & 208 & $0.477^{1}$ \\
Dimension & 3.67 & 0.053 & Total & 392.665 & 209 & 1.089 \\
\hline
\end{tabular}


The difference between the mean scores of sustainable development attitude of elementary school students is not statistically significant according to the location variable $(p>0.05)$ and according to the gender- and school-type variable it is statistically significant $(p<0.05)$ (Table 7$)$. The effect size of the difference between gender-variable scores $\left(\eta^{2}\right)$ 0.46; the effect size of the difference between school type scores $\left(\dot{\eta}^{2}\right)$ was calculated as 0.40 and these values were determined to be a moderate effect since they were $0.2<$ Cohen's $d<0.8$. Female students have higher attitudes towards sustainable development than male students. This can be interpreted as the lower mean scores of the ecological footprints of female students than male students (Table 4) and they feel more responsible for using environmental resources more effectively. Sustainable development attitude mean scores of the students in the secondary school education process are higher than the students in the primary education process which is the previous education level. This situation can be interpreted as the education process increasing the students' sustainable development attitude mean scores with moderate effect, just like the mean ecological footprint scores.

Table 7. Comparison of sustainable development attitude mean scores with independent groups $t$-test.

\begin{tabular}{|c|c|c|c|c|c|c|c|}
\hline \multicolumn{2}{|c|}{$\begin{array}{c}\text { Sustainable Development Attitude } \\
\text { Mean Scores }\end{array}$} & $\mathbf{N}$ & $\overline{\mathbf{X}}$ & Std. & sd & $t$ & $p$ \\
\hline \multirow{2}{*}{ Gender } & Female & 114 & 3.77 & 0.72 & \multirow{2}{*}{208} & \multirow{2}{*}{3.343} & \multirow{2}{*}{$0.001^{1}$} \\
\hline & Male & 96 & 3.44 & 0.70 & & & \\
\hline \multirow{2}{*}{ Location } & County & 99 & 3.52 & 0.66 & \multirow{2}{*}{208} & \multirow{2}{*}{-1.882} & \multirow{2}{*}{0.061} \\
\hline & City Centre & 111 & 3.71 & 0.77 & & & \\
\hline \multirow{2}{*}{ Type of School } & Primary School & 76 & 3.43 & 0.87 & \multirow{2}{*}{208} & \multirow{2}{*}{-2.831} & \multirow{2}{*}{$0.005^{2}$} \\
\hline & Secondary School & 134 & 3.73 & 0.61 & & & \\
\hline
\end{tabular}

${ }^{1} \mathrm{t}(208)=3.343 ; p=0.001 ; \eta^{2}=0.46^{2} \mathrm{t}(208)=-2.831 ; p=0.005 ; \dot{\eta}^{2}=0.40$.

5.3. The Findings on the Relationship Between the Mean Scores of Ecological Footprints of Elementary School Students and the Mean Scores of Attitude Towards Sustainable Development

The relationship between the mean scores of ecological footprints of elementary school students and the mean scores of sustainable development attitudes was revealed. In order to reveal this relationship, "Pearson Correlation Coefficient" was based on by performed correlation analysis. 
A negative correlation was determined between the mean scores of ecological footprint of elementary school students and the mean scores of sustainable development attitude $(0.30<|\mathrm{r}|<0.70)$ and this relationship was determined to be significant $(p<0.01)$ (Table 8$)$. This result shows an inverse relationship between ecological footprint and sustainable development for elementary school students. The low ecological footprint mean scores of elementary school students may be related to the increase in sustainable development attitudes or the high ecological footprint mean scores may be related to the low mean sustainable development attitude scores.

Table 8. Correlation between the ecological footprint mean scores and sustainable development attitude mean scores.

\begin{tabular}{|c|c|c|c|}
\hline & & $\begin{array}{c}\text { Ecological Footprint } \\
\text { Mean Scores }\end{array}$ & $\begin{array}{c}\text { Sustainable Development } \\
\text { Attitude Mean Scores }\end{array}$ \\
\hline \multirow{3}{*}{$\begin{array}{l}\text { Ecological Footprint } \\
\text { Mean Scores }\end{array}$} & Pearson Correlation & 1 & -0.348 \\
\hline & Sig. (2-tailed) & & $0.000^{1}$ \\
\hline & $\mathrm{N}$ & 210 & 210 \\
\hline \multirow{3}{*}{$\begin{array}{l}\text { Sustainable Development } \\
\text { Attitude Mean Scores }\end{array}$} & Pearson Correlation & -0.348 & 1 \\
\hline & Sig. (2-tailed) & $0.000^{1}$ & \\
\hline & $\mathrm{N}$ & 210 & 210 \\
\hline
\end{tabular}

\section{Discussion}

In this study, the relationship between elementary school students' ecological footprint mean scores and their attitudes towards sustainable development was investigated. As a result of the research, the mean ecological footprint scores of elementary school students were calculated as 2.11 gha. Elementary students' ecological footprint has been determined to be lower than Turkey mean (2.7 gha), but higher than the world mean (1.8 gha) (WWF 2012). At the same time, in a study conducted with consumers in Turkey, the ecological footprint mean rate was determined to be low with 2.26 gha and the ecological footprints of individuals have been demonstrated to be on an inadequate level (Özgen and Aksoy 2017). In their study based on the calculation of ecological footprint, Ak1llı et al. (2008) emphasized that the amount of ecological footprint per person should be no more than 1.8 gha and that this value should not be exceeded in terms of sustainability. Even if it is a developed or developing country, it should make significant improvements in resource utilization efficiency (reducing waste, turning to sustainable resources, systematically separating economic activity from environmental impacts, etc.) and 
try to reduce material consumption levels by balancing (Farmer and Cook 2013). This effect should start with students from an early age. According to Grigoryeva (2010), using the ecological footprint in ecology education serves as an effective tool in planning students' environmental behaviors. By using ecological footprint training practices, students' attitudes, awareness and behaviors towards environmental problems can be changed (Çetin 2015). Making ecological footprint calculations of students at all levels of education can be considered as a starting point in recognizing their consumption habits and raising awareness of a sustainable world. This is because, with ecological footprint calculations, students pay attention to how their consumption can destroy natural resources and how global environmental problems can occur.

The difference between the ecological footprint mean scores of elementary school students was determined to be statistically significant according to the type of school variable and the effect size of this difference was determined to be moderate. The mean ecological footprint scores of the students in the secondary school education process were lower than the students in the primary school education process, which was interpreted as reducing the mean ecological footprint scores of the students with moderate impact. Students involved in the education process learn about many concepts such as environment, ecology, consumption, environmental awareness, etc., and that information changes their attitudes and behaviors towards the environment. Keleş (2011) concluded that the information and activities transferred to the students during the course of the study were effective at all grade levels and caused a decrease in the ecological footprint scores of the students. According to Kiziroğlu (2001), as individuals learn positive and negative effects on the continuity of ecosystem, they act more responsibly in matters related to the environment. Since most human activities strongly affect ecosystems, the awareness of responsibility required for the individual should be raised for the care and protection of nature (Chapin et al. 2011). When evaluated from this perspective, presenting the concept of ecological footprint to the students from early classes, and arranging in-class and out-of-class applications that highlight this concept may be effective in creating the desired awareness and decreasing the mean of ecological footprint. When some studies in the literature are examined (Meyer 2004; Weinberg and Quesenberry 2010; Benzer and Şahin 2012; Özgen and Aksoy 2017), it can be seen that active participation practices are effective in creating ecological footprint awareness and creating sustainable environmental awareness.

The mean score of attitude towards sustainable development of elementary school students was calculated $(\bar{X}=3.62)$, and the low mean score showed that 
elementary school students did not exhibit the expected sustainable development attitude. When the answers they gave to the scale items were examined, it was determined that most of the elementary school students could not provide sufficient answers in some social, environmental and economic items. Most of the decisions that adversely affect the ecosystems were taken with the need to maintain certain socioeconomic benefits, rather than being intentionally misused (Chapin et al. 2011). With regards to sustainable development, the environmental dimension indicates the protection of natural environment and biological diversity in which human activities take place (Koçak and Balcı 2010), the economic dimension indicates the use of natural resources in production process (Goodland 1995), the social dimension indicates inter-communal equality (poverty reduction) and protection of cultural diversity (Moffatt 1996). When these three dimensions are considered as a system, it becomes clear that sufficient consumption of resources and environmental behavior should be established to ensure an environmentally sustainable development. Environmental education issues integrated with curricula should take place at all levels and levels of education, as they have a facet that covers all segments of society. In their studies, McMillan et al. (2004) evaluated the environmental values of the classes that carry out studies at university level and take courses. They emphasized that the ecological footprint test applied to university students and the video they watched had a major impact on developing value judgments towards the environment.

It was determined that the difference between the average scores of sustainable development attitude of elementary school students is statistically significant according to the gender and school type variable and the effect size of this difference is medium. Female students' attitudes towards sustainable development were determined to be higher than male students. Özdemir et al. (2004) and Şama (2003) determined that female students had more knowledge about the environment than boys and they paid more attention to environmental issues. In this study, the mean ecological footprint scores of female students are lower than male students and it can be interpreted that the sustainable development attitude mean may be higher because they feel more responsible for using environmental resources more effectively. The sustainable development attitude mean scores of the students in the secondary education process are higher than the students in the primary education process, which is the previous education level. This situation can be interpreted as the education process increasing the students' sustainable development attitude mean scores with moderate effect, just like the mean ecological footprint scores. According to Simon (2009), education plays a key role in the development of sustainability. As the 
education level increases, individuals' perception, attitude and behavior towards sustainability will develop.

A negative correlation was determined between the mean scores of ecological footprints of elementary school students and the mean scores of sustainable development attitude and it was concluded that this relationship was significant. This result shows an inverse relationship between ecological footprint and sustainable development for elementary school students. Therefore, when elementary school students are able to keep their ecological footprint mean scores lower, it will help them to increase their attitude towards sustainable development. Weinberg and Quesenberry (2010), in their study, gave students the key concepts of global, local sustainability theme and gave them ecological footprint education. As a result of the research, they found out that the students see how individual and national ecological footprints are structured and understand the importance of sustainable life. Meyer (2004) concluded that the ecological footprint analysis and activities used as an environment education tool increased the awareness of the individuals participating in the research in a positive way, developed their attitudes in a moderate positive way and were effective in acquiring responsible behaviors towards sustainable living. van Vuuren and Smeets (2000) stated that the concept of ecological footprint is an interesting tool affecting consumption preferences. Hart (2003) suggests that teachers should engage in practical activities in their classrooms in the form of theory, activity and community building in order to achieve the goal of environmental education. Therefore, ecological footprint can be used theoretically and practically in educational processes as an educational tool in changing consumption habits and ensuring sustainable development.

Individuals' attitude towards an event or fact constitutes a general design of his behavior type for that object. There are cognitive, emotional and behavioral elements in the formation of this attitude. Attitudes and behavioral patterns consists of action, target for action, content for action and time elements. A general or specific pattern of these four elements is provided with attitudes towards action (Ajzen and Fishbein 1977). The first step to create this attitude starts with creating awareness. In order to ensure sustainability, this awareness will be created first, and then individual responsibility, behavior change, development will continue and sustainable development will be ensured (Lourdel et al. 2006). Thus, this process will be completed. Therefore, creating ecological footprint awareness in students will be a beginning for sustainable awareness and will prepare the ground for transformation into behavior change by taking responsibility. Negev et al. (2008) found a strong relationship between the nature of children and their attitudes and behaviors and 
stated that it would be effective in developing awareness, attitudes and behaviors that would occur in children.

\section{Conclusions}

Achieving sustainable development is primarily possible by changing the consumption habits of individuals. Children, who are the guarantee of the future, should play a critical role in the success of this change. One of the most important ways to contribute to this process is to train them in the best way. This is because when children interact with society, they will both socialize and also affect the development of society (Lucerne Declaration 2007). Starting environmental education with the concept of ecological footprint contributes to the awareness of students' own consumption habits, the development of the expected features, and thus the development of sustainable development by using natural resources more effectively. The results of this study will provide an insight to readers and education practitioners to demonstrate the relationship between ecological footprint and sustainable development. In this way, it will increase the studies on ecological footprint awareness and, by creating awareness, it will be possible to develop an attitude towards the environment and create environmental behavior. This training process will be an important step in achieving sustainable development. Thus, a step may be taken in reaching the "Quality Education" targets expected from SDG's goal 4.

Conflicts of Interest: The author declares no conflict of interest. There were no founding sponsors who had a role in the design of the study; in the collection, analyses, or interpretation of data; in the writing of the manuscript, and in the decision to publish the results. 


\section{Appendix A}

Distribution of elementary school students' attitudes towards sustainable development.

Social Dimension of Sustainable Development (S)

Environmental Dimension of Sustainable Development (C)

\begin{tabular}{|c|c|c|c|c|c|c|}
\hline \multirow{2}{*}{$\begin{array}{l}\text { S-1. I believe that transferring cultural } \\
\text { heritage to future generations is important }\end{array}$} & $\mathrm{N}$ & 31 & 30 & 5 & 61 & 83 \\
\hline & $\%$ & 14.8 & 14.3 & 2.4 & 29.0 & 39.5 \\
\hline \multirow{2}{*}{ S.2. I respect different opinions and ideas } & $\mathrm{N}$ & 19 & 15 & 29 & 84 & 63 \\
\hline & $\%$ & 9.0 & 7.1 & 13.8 & 40.0 & 30.0 \\
\hline \multirow{2}{*}{ S.3. Social rules are important to me } & $\mathrm{N}$ & 13 & 22 & 12 & 77 & 86 \\
\hline & $\%$ & 6.2 & 10.5 & 5.7 & 36.7 & 41.0 \\
\hline \multirow{2}{*}{ S.4. Society's interests come first } & $\mathrm{N}$ & 20 & 14 & 83 & 53 & 40 \\
\hline & $\%$ & 9.5 & 6.7 & 39.5 & 25.2 & 19.0 \\
\hline \multirow{2}{*}{ S.5. I empathize when evaluating a behavior } & $\mathrm{N}$ & 10 & 26 & 76 & 30 & 68 \\
\hline & $\%$ & 4.7 & 12.3 & 36.2 & 14.2 & 32.6 \\
\hline \multirow{2}{*}{ S.6. I accept individuals as they are } & $\mathrm{N}$ & 12 & 22 & 44 & 82 & 50 \\
\hline & $\%$ & 5.7 & 10.5 & 21.0 & 39.0 & 23.8 \\
\hline \multirow{2}{*}{ S.7. I am unbiased when evaluating events } & $\mathrm{N}$ & 9 & 52 & 72 & 31 & 46 \\
\hline & $\%$ & 4.3 & 24.8 & 34.3 & 14.8 & 21.9 \\
\hline \multirow{2}{*}{$\begin{array}{l}\text { S.8. When I speak, I take care not to say } \\
\text { anything that will hurt the people in front of } \\
\text { me }\end{array}$} & $\mathrm{N}$ & 12 & 28 & 79 & 40 & 51 \\
\hline & $\%$ & 5.7 & 13.3 & 37.6 & 19.0 & 24.3 \\
\hline \multirow{2}{*}{$\begin{array}{l}\text { C.1. Damages to the environment make me } \\
\text { sad }\end{array}$} & $\mathrm{N}$ & 10 & 16 & 43 & 66 & 75 \\
\hline & $\%$ & 4.8 & 7.6 & 20.5 & 31.4 & 35.7 \\
\hline \multirow{2}{*}{$\begin{array}{l}\text { C.2. I prefer public transport because I think } \\
\text { about the environment }\end{array}$} & $\mathrm{N}$ & 31 & 34 & 66 & 48 & 31 \\
\hline & $\%$ & 14.8 & 16.2 & 31.4 & 22.9 & 14.8 \\
\hline \multirow{2}{*}{$\begin{array}{l}\text { C.3. I act economical when consuming } \\
\text { natural resources (water, fuel, energy, etc.) }\end{array}$} & $\mathrm{N}$ & 7 & 17 & 61 & 45 & 80 \\
\hline & $\%$ & 3.3 & 8.1 & 29.0 & 21.4 & 38.1 \\
\hline \multirow{2}{*}{ C.4. I take care not to damage natural habitats } & $\mathrm{N}$ & 3 & 22 & 48 & 58 & 52 \\
\hline & $\%$ & 1.4 & 10.5 & 22.9 & 40.5 & 24.8 \\
\hline \multirow{2}{*}{$\begin{array}{l}\text { C.5. I prefer environmentally friendly } \\
\text { products instead of plastic products that take } \\
\text { a long time to decompose in nature }\end{array}$} & $\mathrm{N}$ & 5 & 37 & 90 & 56 & 22 \\
\hline & $\%$ & 2.4 & 17.6 & 42.8 & 26.6 & 10.5 \\
\hline \multirow{2}{*}{$\begin{array}{l}\text { C.6. I take care to throw the trash into the } \\
\text { trash can }\end{array}$} & $\mathrm{N}$ & 5 & 23 & 45 & 53 & 84 \\
\hline & $\%$ & 2.4 & 11.0 & 21.4 & 25.2 & 40.0 \\
\hline
\end{tabular}




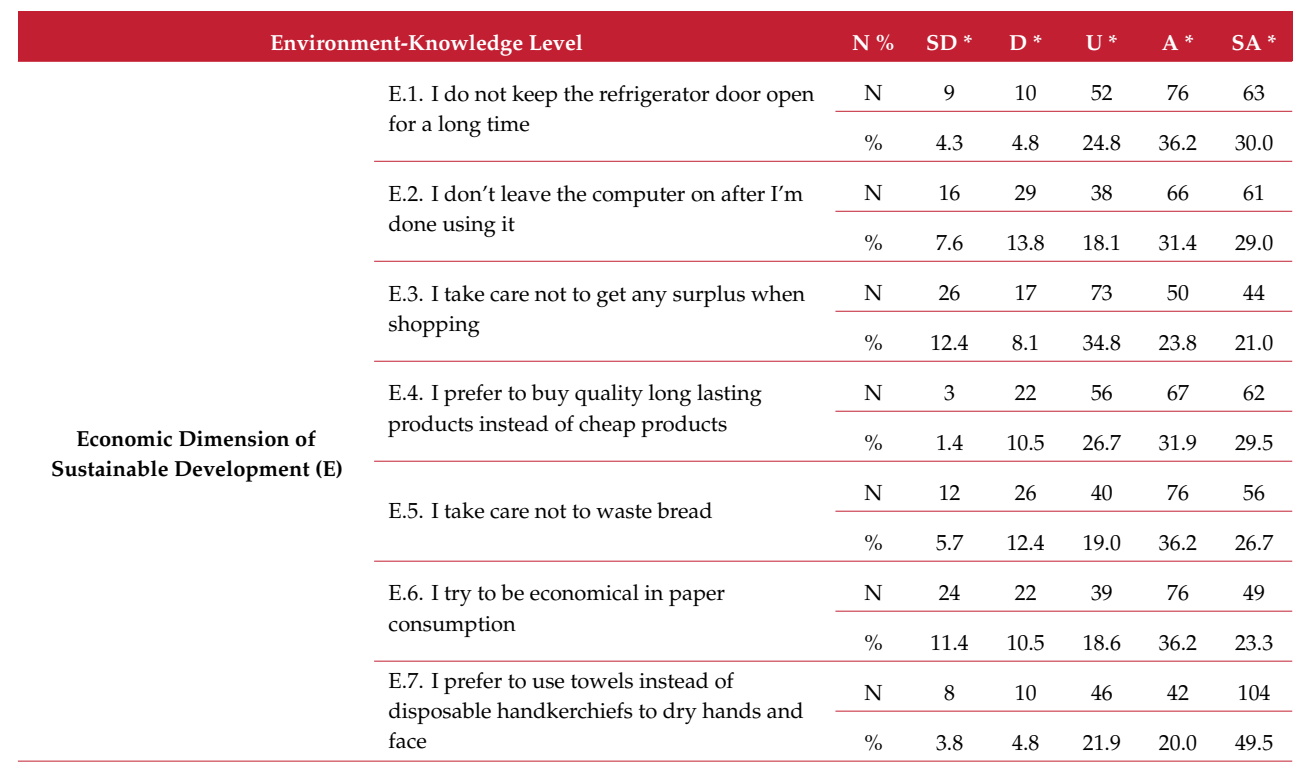

* SD: Strongly Disagree D: Disagree U: Undecided A: Agree SA: Strongly Agree

\section{References}

Ajzen, Icek, and Martin Fishbein. 1977. Attitude-behavior relations: A theoretical analysis and review of empirical research. Psychological Bulletin 84: 888-918. [CrossRef]

Akıllı, Hüsniye, Funda Kemahlı, Kadriye Okudan, and Ferihan Polat. 2008. The content of ecological footprint concept and calculation of individual ecological footprint in the Akdeniz Universty Economics and Administrative Sciences Faculty. Akdeniz University Journal of Economics \& Administrative Sciences 15: 1-25.

Aydın, Özge, and Necdet Aykaç. 2016. The effect of the education implemented by the creative drama method on the environmental awareness of pre-school students. Creative Drama Journal 11: 1-16.

Bastianoni, Simone, Valentina Niccolucci, Riccardo M. Pulselli, and Nadia Marchettini. 2012. Indicator and indicandum: "Sustainable way" vs. "prevailing conditions" in the ecological footprint. Ecological Indicators 16: 47-50. [CrossRef]

Benzer, Elif, and Fatma Şahin. 2012. Evaluation of preservice science teachers' environmental literacy by using case studies throughout project based learning. Marmara University Journal of Educational Sciences 35: 55-83.

Borden, Richard J. 1985. Personality and Ecolojical Concerns. Ecolojical Beliefes and Behaviour. Greenwood: Westport. 
Büyüköztürk, Şener, Ebru K. Çakmak, Özcan E. Akgün, Karadeniz Şirin, and Funda Demirel. 2012. Scientific Research Methods, 12th ed. Ankara: Pegem Akademi Publishing.

Çetin, Fahriye A. 2015. The Effect of Ecological Footprint Education on 8th Grade Students' Attitude, Awareness and Behavior Towards Sustainable Life. Master's thesis, Gazi University Graduate School of Educational Sciences, Ankara, Turkey.

Chapin, F. Stuart, III, Pamela A. Matson, and Peter M. Vitousek. 2011. Principles of Terrestrial Ecosystem Ecology. Berlin: Springer Science \& Business Media.

Collin, Peter H. 2011. Dictionary of Environment \& Ecology, 5th ed. London: Bloomsbury Publishing. Coşkun, Işıl Ç., and Rabia Sarıkaya. 2014. Investigation of ecological foot print levels of classrom teacher candidates. Turkish Studies 9: 1761-87.

Cunningham, Wm, and Mary A. Cunningham. 2018. Environmental Science: A Global Concern, 14th ed. New York: McGraw-Hill Education.

EPA. 1999. Recycling Works. Washington: EPA.

Farmer, G. Thomas, and John Cook. 2013. Climate Change Science: A Modern Synthesis: Volume 1-The Physical Climate. Berlin: Springer Science \& Business Media.

Goodland, Robert. 1995. The concept of environmental sustainability. Annual Review of Ecology and Systematics 26: 1-24. [CrossRef]

Grigoryeva, Victoria V. 2010. Research of Parameters of a Personal Ecological Footprint as an Effective Tool of Education for Sustainable Development. Paper presented at the Footprint Forum, Italy, June 9-10.

Günal, Nazlı. 2018. Evaluation of University Students' Trends in Reducing Ecological Footprint. Master's thesis, Gazi University Graduate School of Natural and Applied Sciences, Ankara, Turkey.

Harris, Jonathan M. 2000. Basic principles of sustainable development. In Dimensions of Sustainable Development. Edited by K. S. Bawa and R. Seidler. Oxford: EOLSS Publisher/UNESCO, pp. 21-41.

Hart, Paul. 2003. Teachers' Thinking in Environmental Education: Consciousness and Responsibility. New York: Peter Lang Publishing.

Huiqin, Li, and Hou Linchun. 2011. Evaluation on sustainable development of scenic zone based on tourism ecological footprint: Case study of yellow crane tower in Hubei Province, China. Energy Procedia 5: 145-51. [CrossRef]

IUCN. 1991. Caring for the Earth: A Strategy for Sustainable Living. Switzerland: The World Conservation Union.

Kaya, Mehmet F. 2013. A scale development study on the attitudes of sustainable development. International Journal of Geography and Geography Education 28: 175-93.

Kaypak, Şafak. 2013. Looking at the environmental peace in the ecological footprint. Turkish Journal of Sientific Reviews 6: 154-159.

Keleş, Özgül. 2011. The effect of learning cycle model on students' reducing ecological footprints. Gaziantep University Journal of Social Sciences 10: 1143-60. 
Keleş, Özgül, and Sibel Özsoy. 2010. Turkey Specific Ecological Footprint Calculator. Global Footprint Network.

Keleş, Özgül, Naim Uzun, and Sibel Özsoy. 2008. Measuring and evaluating pre-service teachers' ecological footprints. Ege Journal of Education 9: 1-14.

Kılıç, Selim. 2014. Effect size. Journal of Mood Disorders 4: 44-60. [CrossRef]

Kiziroğlu, İlhami. 2001. Ecological Potpourri. Ankara: Takav Publishing.

Koçak, Funda, and Velittin Balc1. 2010. The environmental sustainability in the sporting events in nature. Ankara University Journal of Environmental Sciences 2: 213-22.

Koru, Ayça T. 2012. Consumption footprint: A look to the world. The Journal of Economics and Society 24: 13-19.

Lourdel, Nathalie, Jan Martin, and Olivier Bérerd. 2006. Overcoming Obstacles to Understanding Sustainable Development-An Approach Based on Personal Experiences. Paper presented at Engineering Education in Sustainable Development Conference, France, October 4-6.

Lucerne Declaration. 2007. Lucerne Declaration on Geographical Education for Sustainable Development. Paper presented at Lucerne-Symposium, Switzerland, July 29-31.

McMillan, Emily E., Tarah Wright, and Beazley Karen. 2004. Impact of a university-level environmental studies class of students' values. The Journal of Environmental Education 35: 19-27. [CrossRef]

Meyer, Verena. 2004. The Ecological Footprints as an Environmental Education Tool for Knowledge, Attitude and Behavior Changes Towards Sustainable Living. Master's thesis, University of South Africa, Unisa.

Misar, R. 2000. Environmental Education. Ankara: Ankara University Faculty of Educational Sciences Alumni Association Publications.

Moffatt, Ian. 1996. Sustainable Development: Principles, Analysis and Policies. London: The Parthenon Publishing.

MoNE. 2017a. Elementary Schools Science (3, 4, 5, 6, 7 And 8th Grades) Curriculum. Ankara: Board of Education and Training.

MoNE. 2017b. Primary School Life Science (3rd, 4th, 5th, 6th, 7th and 8th Grades) Curriculum. Ankara: Board of Education and Training.

MoNE. 2017c. Elementary Social Studies (3rd, 4th, 5th, 6th, 7th and 8th Grades) Curriculum. Ankara: Board of Education and Training.

Negev, Maya, Gonen Sagy, Yaakov Garb, Alan Salzberg, and Alon Tal. 2008. Evaluating the environmental literacy of Israeli elementary and high school students. The Journal of Environmental Education 39: 3-20. [CrossRef]

Özbuğutu, Emrah, Serdar Karahan, and Çetin Tan. 2014. Environmental education and its alternative methods-A literature review. Mustafa Kemal University Journal of Graduate School of Social Sciences 11: 393-408. 
Özdemir, Oya, Ayşe Yıldız, Esin Ocaktan, and Özlem Sarışen. 2004. Awareness and sensibility levels of medical students. Journal of Ankara Medical School 57: 117-27.

Özgen, Uğur, and Aybala D. Aksoy. 2017. Ecological footprint awareness levels of consumers (sample of Ankara province). Third Sector Social Economic Review 52: 46-65.

Peng, Wenjun, Xiaoming Wang, Xiaokang Li, and Chenchen He. 2018. Sustainability evaluation based on the emergy ecological footprint method: A case study of Qingdao, China, from 2004 to 2014. Ecological Indicators 85: 1249-61. [CrossRef]

Pooley, Julia A., and Moria O'Connor. 2000. Environmental education and attitudes: Emotions and beliefs are what is needed. Environment and Behavior 32: 711-23. [CrossRef]

Reece, Jane B., Lisa A. Urry, Michael L. Cain, Steven A. Wasserman, Peter V. Minorsky, and Robert B. Jackson. 2013. Campbell Biology. Ankara: Palme Publishing.

Rudolpha, Alexandra, and Lukas Figge. 2017. Determinants of ecological footprints: What is the role of globalization? Ecological Indicators 81: 348-61. [CrossRef]

Sam, Neslihan, Sevda Gürsakal, and Rıza Sam. 2010. Assessing environmental risk perceptions and environmental attitudes of university students. Akademik Bakış Dergisi 20: 1-16.

Şama, Erdoğan. 2003. Teacher candidates' attitudes toward environmental problems. Journal of Gazi Education Faculty 23: 99-110.

Sauvé, Lucie. 2005. Una cartografía de corrientes en educación ambiental (A map of currents in environmental education). In A Pesquisa em Educação Ambiental: Cartografias de uma Identidade Narrativa em Formação. Edited by M. Sato and I. Porto. Alegre: Artmed.

SDGs. 2015. 17th United Nation Sustainable Development Goals. Washington: United Nations Environment Program.

Simon, Szabolcs. 2009. Environmental education for sustainability. Practice and Theory in Systems of Education 4: 10-14.

Soussan, J. G. 1992. Sustainable development. In Environmental Issues in the 1990's. Edited by M. Mannion and S. R. Bowlby. New York: John Wiley \& Sons, pp. 21-35.

Stockemer, Daniel. 2019. Quantitative Methods for the Social Sciences: A Practical Introduction with Examples in SPSS and Stata. New York: Springer International Publishing.

Taylor, Neil, Tamar Doff, Kathy Jenkins, and Julie Kenne. 2007. Environmental knowledge and attitudes among a cohort of pre-service primary school teachers in Fiji. International Research in Geographical and Environmental 16: 367-79. [CrossRef]

Tbilisi Declaration. 1977. Available online: https://www.gdrc.org/uem/ee/tbilisi.html (accessed on 15 August 2019).

UNCED. 1992. The Global Partnership for Environment and Development: A Guide to Agenda 21. Geneva: United Nations Commission on Environment Development.

van Vuuren, Detlef P., and Edward M. W. Smeets. 2000. Ecological footprints of Benin, Bhutan, Costa Rica and the Netherlands. Ecological Economics 34: 115-30. [CrossRef]

Wackernagel, Mathis, and William Rees. 1996. Our Ecological Footprint Reducing Human Impact on The Earth. Canada: New Society Publishers. 
Weinberg, Randy, and Jeria Quesenberry. 2010. Introducing the Footprint in Information Systems Education. Paper presented at the Footprint Forum, Italy, June 9-10.

WWF. 2012. Living Planet Report 2012, Biodiversity, Biocapacity And Better Choices. Washington: World Wildlife Fund.

WWF. 2018. The Human Footprint. Washington: World Wildlife Fund.

Yıldırım, Ali, and Hasan Şimşek. 2013. Qualitative Research Methods in Social Sciences, 9th ed. Ankara: Seçkin Publishing.

Yildız, Emre, and Mahmut Selvi. 2015. The ecological footprints and the views on ways to reduce the ecological footprint of pre-service science teachers. Gazi University Journal of Gazi Educational Faculty 35: 457-87.

Yücel, Elif Ö., and Muhlis Özkan. 2013. Comparison of 2013 science education curriculum with the 2005 science and technology curriculum in terms of environmental topics. Journal of Uludă̆ University Faculty of Education 26: 237-65.

(C) 2021 by the author. Licensee MDPI, Basel, Switzerland. This article is an open access article distributed under the terms and conditions of the Creative Commons Attribution (CC BY) license (http://creativecommons.org/licenses/by/4.0/). 



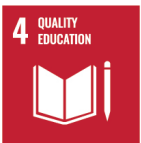

\title{
Possibilities of Popularizing a Philosophy Course in High Schools: The Case of Croatia
}

\author{
Martina Matišić and Kristijan Krkač
}

\section{Introduction}

Concerning sustainability in general, and specifically, sustainable education and lifestyles, philosophy largely cannot do much. However, it can teach, particularly in high schools, how to form individual and group rational justification of basic sustainability concepts and actions. In this view, it can initiate the formation of a rational sustainable worldview and lifestyle. In what follows, a way to achieve this by teaching popular philosophy will be described and, in contrast, a poor case of philosophy teaching in Croatia will analyzed.

\subsection{The Motive}

After the 27 years of existence of the International Philosophy Olympiad, which is a "competition for high school students", and after 12 years of participation, Croatia has a gold medalist at the competition. Namely, Viktor Mršić won the gold medal with his essay on the topic related to a quote of Donna J. Haraway's 1991 book of essays Simians, Cyborgs, and Women: The Reinvention of Nature (International Philosophy Olympiad 2019). Haraway's book, in all of its essays, deals with the relation between humans and cyborgs on many levels, as well as with the relation of nature and technology. This great success goes along with the much more frequent success of Croatian high school students in fields of information sciences, invention, mathematics, physics, and other STEM fields in similar international competitions (STEM-Science, Technology, Engineering, and Mathematics).

Opposed to this success, in an ironic manner, stands a series of facts about the Croatian high school educational system and its poor results, and the presumed quality of Croatian philosophy in general and of high school philosophy courses specifically. The first fact can be easily checked by various standings of Croatia's educational system compared to other European countries or globally, such as the Program for International Student Assessment (PISA) on math, science, and reading, in which Croatia is in 36th place out of 70 countries measured in the period 2015-2016 (PISA Worldwide Ranking-Average Score of Math, Science and Reading-FactsMaps 2019). This is not direct data on philosophy, but without any opposing fact, it points 
to the standings of the education system in general and the philosophy course that is part of it. Without any particular evidence to the contrary, it can be presupposed that the standing of philosophy is the same (Krkač and Cerovsky 2012).

Concerning data on Croatian philosophy in general, there is a lack of data on the national and international level. We performed a preliminary review of 120 Croatian philosophers (the total number of citations and the number of citations for their most cited works via Google Scholar). The results indicated that two-thirds have less than 50 citations, one-third less than 20, and the most cited works of the first 30 philosophers have, on average, 35 citations, given that the majority of these works (papers and books) are published in Croatian journals and publishers, and only a minority in world known journals and publishing houses. As in the previous case, this is not direct data on the quality of work of Croatian high school philosophy teachers but, as these works are teaching the future high school teachers, it seems relevant.

It should be noted that in the fields of teaching, methods, didactic tools, and, more generally, in the pedagogy of high school philosophy, Croatian philosophers do not show results, which is insinuated by the previous notes (again, there is no hard data on this topic). This case can be researched indirectly by an analysis of the history of high school philosophy textbooks in Croatia (which will be conducted hereafter).

\subsection{The Research Plan}

In the following text, we will describe, analyze, and review the present standings of high school philosophy teaching and point to possible improvements which could make a high school philosophy course more connected to other courses and closer to students, their daily lives, and interests. This could point directly to a more sustainable education and only indirectly to a higher quality education in the case of high school philosophy. Shortly, hereafter, we will supply a research plan concerning the changes in high school philosophy courses. The mentioned description, analysis, review, and suggestions will be performed in the following way.

- First, we will supply a theoretical context for a different understanding of the high school philosophy course in gymnasium-based educational systems. This understanding is based on the inclusion of a series of topics in popular philosophy as the philosophy of popular phenomena and the inclusion of modern teaching methods and tools, such as philosophy in comic book format or philosophy through film.

- Second, we will suggest some principles of remodeling for high school philosophy courses based on previous descriptions of different understandings 
of philosophy that are popular, but also with the inclusion of inter-course topics that overlap with two or more courses different from philosophy. Specifically, with courses that can and should form "topics" concerning issues of sustainable development (such as ethics, biology, chemistry and geography).

- Third, we will present the results of the primary research concerning high school philosophy course textbooks in Croatia in the period 1965 to 2019.

The overall idea of the text is to set parameters for future research including:

- conceptual research of popular philosophy and its place in the high school philosophy plan;

- remodeling of the plan for high school philosophy courses in accordance with the previous conceptual research;

- quantitative research of students' opinions concerning the remodeled curriculum;

- possible testing of the remodeled curriculum in experimental education.

Therefore, the whole paper can be understood as a review of past and present situations in teaching philosophy in high school courses and as a plan for future research of possible improvements of the present model in terms of conceptual research, offering remodeling of the present curriculum of the philosophy course and testing the remodeled course in various ways, from gaging the opinions of students to experimental in-class testing.

\subsection{Limitations of the Research Plan}

There are various objective limitations of research designed in such a way. We cannot elaborate on all of them, but the most dominant should be mentioned.

First of all, stricto sensu, the research applies only to high school systems in which there is a philosophy course. Therefore, it applies to, for example, the German, Italian, Austrian, Portuguese, Croatian, and similar systems (Philosophy Education 2019). Some of these systems have already had various improvements in the overall high school curriculum and such improvements will be considered here. On the other hand, some have remained "classical" in their philosophy curriculum, plan, content, and practice. The present research plan can be applied much easier to the curricula that have only an overall course in Social Sciences or in Social Sciences and Humanities, because elements of philosophy, and especially of popular philosophy, could fit better.

Second, the research assumes the reality of philosophy in contemporary societies. The reality is that studies of philosophy at universities have been shut down or will be in the near future (based on highly dubious reasons, but this goes beyond the topic). 
Additionally, the reality is that general high schools (or gymnasiums, especially classic gymnasiums) are becoming less and less popular compared to STEM and vocational high schools. On the other hand, three-subject university studies (A, B, C) in most cases include philosophy; the study of PPE (Philosophy, Politics, and Economics) seems to be quite popular and, if this is the case, high school philosophy courses should remain in one form or another (for examples of similar high school and college textbooks, see (Jalšenjak and Krkač 2012; Krkač and Jalšenjak 2015, 2016)).

Last but not least, the research proposed hereafter applies only to cases in which there is clear and applicable use of popular philosophy in the overall high school curriculum and in the philosophy course. However, there is no proof of that. The research assumes that the philosophy course is there and that it will remain there, but there is no reason whatsoever that this will be the case. There is much more evidence that one or a maximum of two courses throughout the whole high school education would be sufficient. They may be, as they are called in some systems, Social Sciences, Humanities, or Social Sciences and Humanities as one course all the way through high school. Concerning this point, it can be said that the proposed research, if performed properly and with positive results, could be applied to all forms of teaching philosophy in high schools, i.e., as an individual course or as a course within the Social Sciences and Humanities (Jalšenjak and Krkač 2018a, 2018b).

\section{Popular Philosophy as Philosophy Popularized by New Media and as Philosophy of Popular Phenomena-A Theoretical Background}

The general idea of popular philosophy and its major conceptual division will be described (in Section 2.1) and a series of examples will be supplied (in Section 2.2).

\subsection{Popular Philosophy}

Concerning the concept and practice of popular philosophy, two factors instantly pop up: firstly, there is no single critically presented and analyzed description of what popular philosophy is, not to mention that there is practically no literature on this issue; second, there are only a series of various philosophical methods and contents that can be identified as popular. Both issues will be mentioned here, and a few directions of their future research will be explicated at the conceptual level. Concerning the basic relation between philosophy and popularity, there is no sharp demarcation. Philosophy is sometimes regarded as utterly difficult, unpopular, professional, rigorous, and academic. Therefore, there cannot be anything popular about it. Sometimes, even some proper philosophical disciplines are not regarded as pure philosophy, for example, disciplines in practical philosophy (ethics, philosophy 
of politics, law, economy, and culture) vs. disciplines in theoretical philosophy (epistemology, ontology, philosophy of language, philosophical logic, philosophy of science, and philosophy of the mind). However, there are papers, books, and even book series (such as The Blackwell Philosophy and Pop Culture Series 2019 and Open Court Popular Culture and Philosophy Series 2019) that exclusively cover topics in popular philosophy (of telecommunications, internet, music, film, sports, etc.). There are various unpopular philosophical topics that are covered by the use of non-standard literary methods (philosophy by means of films, comic books, etc.). The reality suggests that there is certainly something popular in relation to philosophy and, in the absence of other suitable expressions, it is convenient to call it popular philosophy.

Popular philosophy is philosophy which is not non-popular and by non-popular, one can regard highly academic, technical, formal, and analytical philosophy in the scope of the hardest theoretical and most abstract philosophical issues (some of which certainly belong to disciplines such as ontology, epistemology, and metaethics). Such issues are rarely popularized (at best, some ideas from them can be presented in a popular manner). The difference between non-popular and popular philosophy is most visible in the case of ethics because the discipline has:

- highly non-popular subdisciplines (such as metaethics);

- semi-popular subdisciplines (such as major general ethical theories, i.e., virtue and duty or utilitarian ethics);

- disciplines that can be popularized because of the fields of application of general ethical theories (e.g., political, legal, economic, social, individual, and other ethics; ethics of technology, science, everyday items, and routines etc.).

Ontology and epistemology also have such issues (e.g., fictive and fiction entities or know-how), but lesser than ethics.

Given that the working description of popular philosophy is correct, the very concept and practice of popular philosophy has two clearly distinct types (perhaps a combined type as well). These are the following:

- popular philosophy as popularizing philosophy, meaning that a non-popular philosophical issue is popularized via some new pedagogical method, media, or didactic tool (in existing examples, there are hard non-popular issues popularized by means of film and comic books, given that films can be documentary, art, or in terms of a blockbuster).

- popular philosophy as the philosophy of popular phenomena (in most cases, interesting to the audience to which the philosophy is taught), such as phenomena 
that are of some daily interest to high school students (in existing examples, philosophy of smart phones, internet, social networks, music, films, clothing, sports, and similar (Krkač 2010)).

Perhaps the type of popular philosophy that combines the first and the second type is in fact the most interesting type because it strives to substantially connect the second type with the first in a way that understanding the philosophy of some popular phenomenon or practice performed in a popularizing manner can contribute to the non-popular philosophy (e.g., ontology of film; for example, the film The Matrix conducted in a video debate can contribute to the non-popular ontological issue of appearance-reality or the realism-antirealism debate).

The proposed division of philosophy (as shown in Table 1) should be conceptually researched and justified. The goal of the proposed research plan is not to exclude or include popular philosophy into philosophy proper or to keep professional and academic philosophy pure, but rather to test the idea that popular philosophy, especially as a philosophy of popular phenomena, could contribute to understanding phenomena that no other field of philosophy can (e.g., philosophy of film can contribute not only to film and its theory but perhaps also to philosophy).

Table 1. The division of philosophy (non-popular and popular).

\begin{tabular}{|c|c|c|c|}
\hline \multicolumn{4}{|c|}{ Philosophy } \\
\hline \multicolumn{4}{|c|}{$\swarrow \searrow$} \\
\hline \multicolumn{2}{|c|}{ Non-popular } & \multicolumn{2}{|c|}{ Popular } \\
\hline$\swarrow$ & $\searrow$ & $\swarrow$ & $\searrow$ \\
\hline $\begin{array}{l}\text { Professional, } \\
\text { academic, } \\
\text { theoretical, and } \\
\text { abstract } \\
\downarrow\end{array}$ & $\begin{array}{c}\text { Professional, } \\
\text { academic, practical, } \\
\text { and applied } \\
\downarrow\end{array}$ & $\begin{array}{c}\text { Popularizing } \\
\text { philosophy by } \\
\text { various means } \\
\downarrow\end{array}$ & $\begin{array}{c}\text { Philosophy of } \\
\text { popular phenomena } \\
\downarrow\end{array}$ \\
\hline $\begin{array}{l}\text { General ontology, } \\
\text { epistemology, } \\
\text { philosophy of } \\
\text { science, meta-ethics, } \\
\text { etc. }\end{array}$ & $\begin{array}{l}\text { General, practical, } \\
\text { applied, and } \\
\text { professional ethics, } \\
\text { philosophy of art, } \\
\text { culture, economics, } \\
\text { law, politics, etc. }\end{array}$ & $\begin{array}{l}\text { Philosophy by } \\
\text { means of theatre, } \\
\text { comics, strip, books, } \\
\text { films, games, etc. }\end{array}$ & $\begin{array}{l}\text { Philosophy of smart } \\
\text { phones, internet, } \\
\text { social networks, } \\
\text { sports, music, } \\
\text { fashion, etc. }\end{array}$ \\
\hline
\end{tabular}

All of these types of popular philosophy are completely absent from the national curriculum philosophy course. This issue will be tackled later on due to the fact that a new philosophy curriculum has been accepted (see (Ministry of Science and 
Education, National Curriculum for the High-School Philosophy Course 2017)). The topic of changes in the high school philosophy course is not specific to Croatia but to the majority of similar European education systems, especially those with a gymnasium program, because they seem to be most resistant to change.

\subsection{Examples of Popular Philosophy}

Here, some examples of popular philosophy of the first and the second type (as previously differentiated) will be supplied. The goal is not to describe these examples in detail and make case studies out of them, but to point to them as possible case studies and experimental topics in the high school philosophy curriculum. It should be noted that although there are numerous examples of popular philosophy as the popularization of philosophy (by comic books, films, etc.) and as the philosophy of popular phenomena (even in a whole book series of various publishers), there is still no single book that theoretically researches the overall nature of popular philosophy and its relation to non-popular or academic philosophy.

\subsubsection{Popular Philosophy as Popularizing Philosophy}

\section{Philosophy by Means of a Comic Book or Strip}

The book series For Beginners Books, Philosophy \& For Beginners Books, Philosophy \& Literature (2019) is the most obvious example of popularizing philosophy in the form of a comic book. The range of topics is wide and it spans highly difficult philosophers to similarly difficult disciplines. Wittgenstein for Beginners (Heaton and Groves 2003) is one such example. The research question here could be: Given the amount of basic information in various popular online encyclopedias and in the book Wittgenstein for Beginners, is it possible to cover the same amount of information in the comic book as in the written entry on a popular online encyclopedia?

We believe that this research question is appropriate and that it indicates that philosophy by means of a comic book makes sense and is more available to 21st century high school students (McLaughlin 2005). The aim of the research would be to verify the hypothesis that popular philosophy as the popularization of philosophy can have a positive relation to subjects of unpopular philosophy through the example of comics. In other words, the aim would be to show that popular philosophy can help unpopular philosophy and make it correlative to the popularization of philosophy and philosophy itself, thus making it more understandable and accessible to high school students. 


\section{Philosophy by Means of Film}

Compared to comic books, film is an even more accessible media for high school students, given the overall interest for films in the adolescent population. There are documentary films, art films, and even some blockbusters that mention major philosophers in history. Here, a distinction should be made. In terms of popularizing philosophy, films are taken as examples of the alternative method of transmission of knowledge about philosophy and not as examples of philosophy of film as popular phenomena (Krkač 2013).

The aim of this part of the research would be similar to the previous one, but considering the special features of film compared to comic books and strips. A rather convenient, and to some degree, comparable, example would be the art film Wittgenstein. ${ }^{1}$

Here, the following steps are needed:

- $\quad$ an introduction to the film;

- a presentation of some elements of philosophical arguments and interpretation of Wittgenstein's philosophy in the film;

- a summary and discussion on a few opposing film reviews;

- the film's relationship to the popular and non-popular philosophy of Wittgenstein.

The second point can contain:

- a detailed analysis of a few important scenes in the film;

- their comparison to a comic book and to various textual introductions to Wittgenstein's philosophy in roughly the same period;

- a discussion on some actual quotes from his major books (Wittgenstein 1998).

Such research would answer the research question-Is it or is it not possible to introduce the philosophy of a particular philosopher, discipline, or topic via film in a way that nothing would be missing compared to the use of a purely textual introduction and lecturing ex cathedra? Our hypothesis is that this would be possible at the level of high school philosophy in cases where lecture topics include concepts (knowledge, reality, and good), disciplines (epistemology, ontology, and ethics), and philosophers (even those quite hard to understand, e.g., Wittgenstein's philosophy).

$1 \quad$ Directed by Derek Jarman, 1993. 


\subsubsection{Popular Philosophy as Philosophy of Popular Phenomena}

\section{Social Networks and Philosophy}

Philosophy of social networks is the first proposed case for future research that belongs to the philosophy of popular phenomena. Social networks are something that nowadays students use all the time for a range of different purposes from simple communication to quite complicated organization of various events, gatherings, and even public actions for various purposes. As such, social networks and the philosophy of them are obviously suitable for introduction to philosophical issues of language, meaning, speech, communication, artificial intelligence, social philosophy issues, etc. There seems to be an obvious positive correlation between the philosophy course and language, sociology, politics, biology, and other high school courses. Such a correlation cannot easily be obtained if the philosophy course is understood as solely a series of abstract, formal problems detached from daily life; philosophers; and philosophical schools and their basic ideas.

The basic research question concerning this and any other popular phenomenon and the philosophy of it would be quite simple-is there a positive correlation between issues in the philosophy of a popular phenomenon, $\mathrm{A}$, and a series of classical philosophical issues, B, C, and D, as well as a positive correlation between the philosophy of A with a series of issues in a course different from the philosophy course?

The best candidate for such future research would be the book Facebook and Philosophy: what's on my mind? (Wittkower 2010), as well as some other papers that discuss other social networks and their philosophical implications. Here, the research would have to be different compared to popular philosophy as popularizing philosophy, since here, the issue is not just the method (didactic and pedagogical tools), but the content. Therefore, the following steps seem to be required:

- $\quad$ research the particular social network (here, Facebook is appropriate);

- present of some topics from the book (here, from Facebook and Philosophy: what's on my mind?);

- describe particular activities on the social network that students are engaged in;

- connect the second and the third point to some philosophical issues that naturally arise from discussing the use of a social network;

- connect the second and the third points to issues in other high school courses.

\section{Film and Philosophy}

Film as a phenomenon in terms of the philosophy of film, and opposed to the philosophy of social networks, is a highly developed discipline. It is a wonder, given 
the popularity of film among adolescents, that at least a chapter on film did not find its way to standard high school philosophy textbooks.

The aim in this part of the research is to test the relationship of the philosophy of film and non-popular philosophy of film in a particular case study. Here, the convenient candidate is the TV series House M. D. ${ }^{2}$

Basic steps of the research would be the following:

- describe the philosophy of film (different schools) and a philosophical discipline (Jarvie 2003);

- describe the actual TV series;

- $\quad$ summarize the basic information on the TV series;

- describe selected topics from the book House and philosophy: everybody lies (Jacoby 2009), some of which should be:

the comparisons and similarities between House and Socrates;

$\bigcirc$ the comparison of House and Nietzsche's concept of superman;

$\bigcirc$ the connection of an example to unpopular philosophy, i.e., the Occam's razor (for example S1E3 from House M. D., "Occam's Razor");

$\bigcirc$ the connection of an example to methodology, i.e., the Socratic Method (for example, a short scene from House M. D., "The Socratic Method" S1E6, The Story behind House's leg).

If results were positive, this case would show that the popular philosophy of a film and TV series (one which gained extreme popularity in recent years, e.g., Game of Thrones (2011-2019), that was started probably by D. Lynch's Twin Peaks (1990-1991, 2017)) is a proper part of philosophy and can be used for its own sake as well as for introducing more abstract issues ((Falzon 2002; Wartenberg and Freeland 1995) etc.), and that simply watching and discussing TV series can contribute to popular and non-popular philosophy by offering new analyses, arguments, and, perchance, insights.

\section{Fashion and Philosophy}

Opposed to social networks and films, fashion is a different issue. Fashion is physically, bodily, and publicly manifested, while films can be watched privately and

2 Directed by David Shore, 2004-2012. Available online: https://vimeo.com/57262156 (accessed on 9 June 2019). 
the use of social networks is basically online. Therefore, this case or example supplies a new aspect of a popular phenomenon in philosophy, of which it manifests differently.

Here again, there are not many examples of the philosophy of fashion (the word philosophy in fashion is often used pejoratively, not even in terms sufficient to be considered popular philosophy). However, the book by H. Widdows Perfect Me: Beauty as an Ethical Ideal (Widdows 2018) is an excellent example.

The most important steps of this analysis include the following:

- description of fashion (Wolfendale and Kennett 2011);

- definition of the philosophy of fashion (Svendsen 2006);

- presentation and analysis of part of the book Perfect me: Beauty as an Ethical Ideal;

- summary of positive and negative reviews of the book;

- the importance of the philosophy of fashion in non-popular philosophy (philosophy of mind, social philosophy, ethics, freedom, etc.).

\section{Music and Philosophy}

Music is an excellent case study because adolescents use it to express their identity (What you listen to is who you are). However, the philosophy of music is not so present in the overall literature in non-popular philosophy (as a part of aesthetics and the philosophy of art). It is present in the literature in popular philosophy (for example (Gracyk and Kania 2011)) but not as a general topic, rather as a series of particular cases, mostly pop and rock bands.

Here, as examples, only books about the philosophy of globally recognized bands exist (such as The Beatles, The Rolling Stones, Pink Floyd, Metallica, etc.), but then again, one should pay close attention to the attitudes and styles of students because this is, in most cases, culturally relative. Beyond globally popular singers, performers, and bands, there is not much uniformity and each group is relative to its further cultural features.

This case is also interesting since it is not wise to presuppose that students nowadays have substantial common knowledge of the genre of music they actually listen to, not even in cases of relatively new genres (it is probable that kids nowadays listening to hip-hop, dance, techno, and generally, pop electronic would not know much about, say, music from the film Breakin' from 1984 or about the band Kraftwerk in the early 1970s).

There is perhaps an even deeper objection to this case. Namely, humans are dominantly oculocentric, meaning that they rely on information they have gathered by sight, and not so much by hearing. Sounds are not a dominant source of our information. This has some consequences for the non-popular and popular 
philosophy of music. However, this can be overcome by relating music to videos and live performances.

If correctly interpreted, this case could show both positive and negative results, given the amount of common knowledge, experience, and interest in music by students. It could show that music is or is not a good case study for proving that the philosophy of music can be, in its own right, an excellent topic in teaching Philosophy and an entrance into more fundamental issues such as the philosophy of hearing, sounds, singing, etc.

\section{Remodeling of the Annual Plan and Program for Philosophy Courses in Croatian High Schools and in Similar Educational Systems}

This part, compared to the previous part which dealt with the contents of popular philosophy, deals with the elements of the proposed research plan that are more technical, pedagogical, methodical, and didactical. The idea here is to research how the contents of popular philosophy can be incorporated into the new high school philosophy curriculum by means of changes in the national curriculum philosophy course.

In four subsections, four elements of this proposal will be described in their most critical elements, except for the first one (Section 3.1), which shortly describes high school philosophy curricula sufficiently similar to the Croatian curriculum because it is quite important that the Croatian example can be, if so wished, applied to other similar systems mutatis mutandis. In the other three subsections (Sections 3.2-3.4), the existing and newly proposed national curriculum philosophy course (with annual plan and program included) are described, analyzed, criticized, and reviewed, and some improvements are suggested.

\subsection{Philosophy in High Schools around the World}

Philosophy is taught mostly in secondary schools in one or more of the last three years of secondary education. In some countries, philosophy is included only in gymnasiums and in, for example, technical and vocational schools. Here are some examples from Philosophy: a school of freedom. Teaching philosophy and learning to philosophize: Status and prospects (UNESCO 2007) of how the philosophy course is applied around the world.

Africa, the Arab World, and the Middle East

In the Central African Republic, there is a course in African philosophy in which African and Western authors are studied. Meanwhile, in Egypt philosophy has been 
taught at the secondary level since 1925 and the primary focus is Islamic philosophy. The philosophy course in Qatar is studied during the final three years of secondary school. Philosophy is part of the curriculum, for example, in Morocco and Tunisia. In Jordan and Sudan, as well as in the Russian Federation, philosophy is not included in school curricula.

\section{Asia and the Pacific}

In Japan, philosophy is taught in primary school and in lower secondary levels in the form of ethical institution and in the secondary level as an optional ethics course, within the general outline of civic education. In India, philosophy appears as Ethical and Environmental Education in the upper secondary level as part of classes in scientific methods, logic, and in history of philosophy courses. Philosophy exists in Thailand through seven years of secondary school but not as a separate course, nor in the context of other courses (including in general and technical schools). In Pakistan, philosophy is studied as an opinion in the Literature, Economics and Social sciences or in combination with other courses.

\section{Americas}

Philosophy has been studied in Brazil as an independent course since 2008. In Uruguay, philosophy is taught in the last three years of secondary school. Philosophy in Mexico is taught in the form of logic and ethics. In the United States, philosophy is not included in the high school system as an obligatory course. Some philosophical courses are offered in some secondary schools, but they are not prescribed by the national model. Additionally, in this report, some examples are given on how philosophy can be taught (in interaction) with other disciplines or courses such as: physics, mathematics, music, visual art, languages, psychology, pedagogy, biochemistry, and sciences.

\section{Continental Europe}

In many countries in Europe, philosophy is a part of the high school curriculum such as in France, Greece, Poland, Portugal, Bulgaria, Italy, Austria, and Germany (they are very similar to the Croatian curriculum). In Germany, philosophy is taught in the last two years of gymnasium, and some regions offer Philosophy as a substitute for students who do not wish to take any religion courses (in the majority of cases, Christianity). Philosophy courses are taught in Austria in economic real gymnasiums. Italian schools include philosophy in all secondary schools in the last three years, including gymnasium (i.e., Liceo classiso which focuses on languages, literatures and 
philosophy), business, vocational, and technical schools thanks to Brocca Programmes (reform of secondary curricula).

French students have a philosophy course in their final year of secondary education. In Portugal, the course Introduction to Philosophy is included in the general education group and all students take two years of philosophy (it is the second most important course in the curriculum). Finland offers the alternative course Ethics and Philosophy of life for students who are not members of a church or religion. In Estonia, philosophy appears under the name Ethical Systems through History, while Belgium offers a religious ethics courses. In Moldavia, philosophy is replaced by civics and law.

\subsection{Correlations and Overlaps of High School Philosophy with Other Courses}

The aim of this section is to propose a research plan for examining the correlations and overlaps of high school philosophy and other courses (arts, language and literature, physics, and politics and economics). This issue is highly culturally and educationally sensitive due to a diversity of overall high school curricula in different countries. However, some principle rules can be described and suggested for application and practical in-class experimental education.

The research plan here would include the examination of possible correlations of the philosophy course with other high school courses in the case of Croatia, and the results could be applied to other high school education systems ceteris paribus.

Particular research steps would include the following elements:

- review of the correlations between philosophy (in strip) and art, interviewing teachers and artists about the importance of art (Kivy 2004) and its relation to philosophy (Lorand 2003);

- review of the correlations between philosophy, the Croatian language and literature, presenting philosophers who won Nobel Prize awards for literature, and review the influence of philosophy on literature (Hagberg and Walter 2010);

- review of the correlations between philosophy and physics, and physics with philosophy (similar for mathematics and information sciences) (Butterfield and Earman 2007);

- review of the correlations between philosophy, politics and economics (McIntyre and Rosenberg 2017).

What is interesting here is that the national curriculum philosophy course (Ministry of Science and Education, National Curriculum for the High-School Philosophy Course 2017) recognizes almost all possible correlations of philosophy 
with other groups of high school courses and with some inter-course topics such as civic education and sustainable development (2017: Section E), but one does not recognize them in major parts of the course, especially not in the obligatory sections. It seems that these correlations are just listed here, but that they play no actual part in the educational process. Students may learn, for example, about the ontological issue of appearance and reality or realism vs. antirealism debate, but they will never have to watch, say, the film The Matrix or discuss personal identity on social networks or discuss fake news in the media and enter into this debate from the point of view that seems to be natural to them.

\subsection{National Curriculum for Philosophy}

The aim of this part of the research would be an examination of the existing national curriculum philosophy course and of the newly proposed course. We have already mentioned its limitations in terms of listing correlations but without the real possibility that students could learn the united parts composed of different parts of different courses, at least at the same time, if not by different professors during the same classes (just imagine that the issue of life or human life is discussed in the same few weeks in all courses and that after the topic, students and professors have a big panel discussion and presentations of students' practical tasks).

None of this can happen in the present scope and limits of the Croatian national curriculum philosophy course. All this did was to separate the majority of already existing topics into major parts, three of which are obligatory while others are not (this will raise some problems concerning the State Matura (national exam), because if a student chooses philosophy as an additional course, all the topics would probably be there and not only those obligatory during the course); this issue applies to all countries that have State Matura (such as Austria, Bulgaria, Croatia, Czech Republic, Hungary, Italy, Liechtenstein, Poland, Slovakia, Slovenia, and Switzerland).

This part of the proposed research plan includes a detailed analysis of the present and near future Croatian national curriculum philosophy course. There are a series of essential documents that need to be reviewed, from the most general strategies to particular plans for the philosophy course and its parts. Why this was not done during the ongoing reform of the system of high school education is completely unknown to the present authors (the previous leaders of the reform claimed that problem-based and topic-based education, or something similar to the Finnish model, is impossible in Croatia; the present leaders claim that it is possible, but as we can see in the case of philosophy, this does not take place either in plans or in practice, given the fact that the present authors have substantial experience in teaching, from 
primary and secondary schools to university undergraduate, postgraduate, and doctoral studies and we should be able to see it if it is there).

On the margin, the new manuals and ideas for new textbooks in philosophy should also be examined. However, nothing special, spectacular, or revolutionary should be expected from the new curriculum, textbooks, or practice. All that was done was a simple rearrangement of the existing topics, methods, and didactical tools. There is nothing on philosophy by comic books, films, or even various games and nothing on the philosophy of popular phenomena (popular to kids, of course) that could at least be used for an easier introduction into hard, theoretical, and abstract philosophical issues (say, of ontology, epistemology, or metaethics).

In the national curriculum philosophy course (2017) that will be implemented from the school year 2021/2022, the philosophy course is placed in the 5th cycle (4th grade of high school), and a total of eight domains are created, of which three are obligatory (Existence and the World, Cognition and Knowledge, Activity, and Orientation), while four domains are selected by a teacher (Ministry of Science and Education, National Curriculum for the High-School Philosophy Course 2017). The negative side of the new curriculum proposal is the obligation to process only three, i.e., four domains out of a total of eight, so it is not defined how the material will fit into all the content required for passing the exam for the State Matura of philosophy. Therefore, in that case, it is necessary to change the content of the State Matura exam and write a new tutorial for philosophy. Since the new curriculum for philosophy only applies to gymnasiums, the way of teaching philosophy in vocational schools, where it is declared as an elective course in certain occupational directions, remains to be seen.

For example, the mandatory domain Existence and the World deals with the questions of metaphysics and ontology through which an opinion on nature, God, and man is formed. Students are expected to differentiate between different scientific approaches to the problem (laws and regulations of the world, the issue of movement, the essence of things, etc.) and philosophy as a universal science.

By dealing with these issues, the student experiences the difficulty of consistent thinking about man and the world, recognizes the importance of basic attitudes for all other considerations, and develops the ability to view problems from different perspectives, regardless of their own beliefs, as well as consistency involving the commitment to the consequences of general attitudes man and the world we accept. (Ministry of Science and Education, National Curriculum for the High-School Philosophy Course 2017)

On the other hand, the negative side is that the national curriculum for gymnasium education (see (Ministry of Science and Education, National Curriculum 
for Gymnasium Education 2017)) has reduced philosophy from an obligatory two hours per week to an obligatory one hour, unless the student chooses a particular elective module that has from one to two hours of teaching, but it is impossible to predict how many students will choose the module (according to the students' interest in philosophy courses so far, it is possible to assume that it will be a minority, but no research on this issue has been conducted among students). In the classical gymnasium school programs, everything remains the same, with the possibility of another two hours if the student chooses a specific module.

\subsection{The Proposal for the Improvement of the Existing Philosophy Curriculum Overall Proposal}

With a small addition to the given curriculum for philosophy, in terms of a single note on freedom of use of contemporary available popularizing tools in philosophy (say strip and film), contemporary literature on philosophy of popular phenomena (some famous books are even translated into Croatian, say, on philosophy, and The Simpsons, Star Trek, etc.), and the creation of actual correlations in terms of projects for the student that would result from grades in different courses depending on the included correlations, this situation could improve.

However, given the practice of high school philosophy in Croatia, on which the present authors have limited objective data, and only personal professional experience, this would hardly be regarded as an improvement to the course-most likely, as the failure to follow the national curriculum philosophy course.

This part of the proposed research plan would have to summarize conclusions of any of the previous parts and apply them to the improvement of the existing curriculum. It also has to set the method of testing the improved curriculum essentially among the students themselves and to provide at least a short plan for the experimental application and implementation of the curriculum (this would certainly include parallel teaching in accordance with the official and the improved and to test students at the end of the course in order to have at least some objective data).

The proposed plan includes the following steps:

- conclusions on the conducted research on popular philosophy, popularized philosophy, and the philosophy of popular phenomena;

- conclusions of the study of the correlations of philosophy with other courses;

- reference to limitations in the creation of a new version of the annual plan and program for the course of philosophy; 
- overview of the possible new version of the annual plan and program for philosophy based on the new curriculum for philosophy with new changes in the teaching content.

Proposal Distinctively Related to the Promotion of Sustainable Development: The Case of Sustainable Lifestyles

The overall proposal in its basic ideas deals with concepts that are related to many important, practical, and daily issues of 21st century adolescents, among which an example of education for sustainable development will be presented here as the possible "topic" crossing the boundaries of the philosophy course.

Philosophy, as a theoretical and practical discipline, among other rational and critical elements, supplies clear concepts and overviews of phenomena and by doing this, helps understanding of sometimes quite different approaches to the same topic.

Concerning the issue of sustainable lifestyles philosophy as described in terms of non-popular and popular philosophy should contribute by correlating different issues and creating an independent trans-course topic in the manner that is most natural to it. Here, we will take an example of life and living beings.

The issue of life is generally studied in philosophy within the limits of philosophical anthropology, in most cases completely unrelated to other clearly close philosophical topics and non-philosophical topics in other courses. The study of the nature of human action, freedom and responsibility, and similar is evidently related to ethics and similar courses (that exist in some high school systems), and to topics in other courses, most important of which seem to be chemistry, biology, sociology (or a social sciences course), and geography. The philosophy of sustainable development under various aspects was justified in the literature, and here, we follow these ideas (see (Papuziński and Pawłowski 2007; Painter-Morland et al. 2017)).

The general issue of sustainable lifestyle should be taught as a unified general topic that revolves around basic concepts of sustainability applied in the daily lives of students. In imagined rotating sub-issues, there should be the applied concepts in different courses, e.g., the concept of living beings in biology and psychology, the concept of environment and sustainability in biology and geography (demography). Issues rotating at the borders of the topic should be related to sustainable practices by schools, teachers, and students in their student, teacher, and private lives. In this way, philosophical insights and conceptual clarity could serve not only as an end in itself, but also as a natural glue for various issues in most cases studied separately (sometimes, even in different years of study in high schools).

It is naïve to set a goal of full understanding of human life and its place among other living and non-living creatures in the world, but to set a goal of initiating such 
understanding by studying philosophy in its non-popular, popular, theoretical and practical aspects, related to similar issues in other courses, is a realistic objective. Philosophy, as described, offers on the one hand a conceptual and analytical rigor and on the other a synthetic overview of the topic and of practice.

- There are many possible practical applications of these ideas related only to the concept of sustainable lifestyles, but we can offer just one that can set if not new contents, then at least some justification and authenticity of a teacher and student. Namely, the most obvious starting point concerning this topic would be to research-how much the overall activity (in-class and outside of it) by students and by a teacher is sustainable? For instance, how much energy is spent-time, effort, physical resources, spaces, etc.—and how the teaching process itself could be made more sustainable. It does not mean much, but it seems to offer a kind of basic authenticity and sincerity if students and teachers are confronted with facts about their energy consumption during classes (say, by heating, light, use of computers, tablets, and smart phones for practical tasks), how much they use sustainable resources (say, recycled paper, pencils, etc.), how much do they contribute in their private lives, etc.

Such cross-course topics and specific issues cannot be taught separately by courses of philosophy, ethics, chemistry, ethics, geography, etc. They should be taught as unified topics that cover many different aspects of the same phenomenon and what is more important to the life of a student. Here, the course of philosophy as practical and popular philosophy can help considerably because first of all, it is at the same time quite strict and rational and on the other hand, open to many different worldviews and creative applications in daily lives. Therefore, the high school philosophy course textbooks should be written in an entirely different manner than they actually are nowadays, in the majority of cases.

\section{Primary Research: Croatian High School Philosophy Textbooks Content 1965-2019}

In this section, since the practice of teaching philosophy cannot be objectively evaluated in the Republic of Croatia, the only possible way to obtain some results and lessons for the future is to conduct indirect research-in this case, the examination of the form and contents of the high school philosophy course textbooks. This will be done for Croatia, but it could apply to any sufficiently similar systems with sufficiently similar textbooks (again, the change in the Italian reform is quite illustrative).

In the two following subsections, two important features of philosophy textbooks will be described and evaluated, namely, the history of philosophy textbooks in 
Croatia from 1965 to 2019 (in the 1st subsection hereafter), and the content of major textbooks from 1973 until 2019 (in the 2nd subsection). This particular period concerning the content is chosen because the official philosophy textbook in 1973 in its many new editions is still used in teaching philosophy in high schools in Croatia.

We are completely aware that this indirect method will supply quite a small amount of data, on which only a few sound conclusions can be drawn, but this is, methodically speaking, all we have available. Any other source would be of even lesser evidential weight. Perhaps various national curricula and annual plans and programs could be additionally researched, but these documents are hard to access and research.

\subsection{The History of High School Philosophy Textbooks in Croatia}

In his book, The Colonizer's Model of the World (1993), J. M. Blaut, concerning textbooks generally, writes the following:

Textbooks are an important window into a culture; more than just books, they are semiofficial statements of exactly what the opinion forming elite of the culture want the educated youth of that culture to believe to be true about the past and present world. A school textbook is truly a key social document, a kind of modern stele. In the typical case, a book becomes accepted as a high school (or lower-level) textbook only after it has been reviewed very carefully by the publisher, school boards, and administrators, all of whom are intensely sensitive to the need to print acceptable doctrine; they are concerned to make it certain that children will read only those facts in their textbook which are considered to be acceptable as facts by the opinion-forming elite of the culture. The resulting textbook is, therefore, less an ordinary authored book than a vetted social statement of what is considered valid and acceptable for entry into the mind of the child. For this reason, research on textbooks (including college textbooks, in which the same process is at work, though more subtly) is, in fact, ethnographic research. It tells us about the belief system of the opinion-forming elite of the culture as a whole. (Blaut 1993, p. 6, footnote 5:46)

This applies to all textbooks, perhaps more to humanities, and especially, high school philosophy textbooks that are open to various methodic and didactic styles and approaches connected to sometimes quite different philosophical schools.

Philosophy textbooks in Croatia have a bit of a strange history. In the following table, some reliable but incomplete data will be presented (Table 2). In Table 2, textbooks are given in the columns in accordance to relevant periods and in the rows, 
there are three major approaches, namely the historical, historical-problem, and problem-based approach.

Table 2. Major Croatian high school philosophy textbooks in the period 1940-2019.

\begin{tabular}{|c|c|c|c|c|c|}
\hline Type & $\begin{array}{c}\text { Before } \\
1945\end{array}$ & \multicolumn{3}{|c|}{ From 1945 to 1990} & From 1990 to 2019 \\
\hline \multirow[t]{2}{*}{ 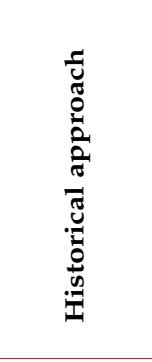 } & \multirow[t]{2}{*}{$\begin{array}{c}\text { History of } \\
\text { philosophy } \\
\text { Bazala (1906, } \\
\text { 1909, 1912) } \\
\text { I-III }\end{array}$} & $\begin{array}{c}\text { Anthology of } \\
\text { philosophical } \\
\text { texts } \\
\text { Bošnjak et al. } \\
\text { (1954), up to } \\
\text { 1965 as a } \\
\text { textbook }\end{array}$ & $\begin{array}{l}\text { History of } \\
\text { Philosophy } \\
\text { Vejnović } \\
\text { (1965), up to } \\
\text { 1973 as a } \\
\text { textbook }\end{array}$ & $\begin{array}{c}\text { History of } \\
\text { Philosophy } \\
\text { Kalin (1973), } \\
1990 \text { and later } \\
\text { as a textbook }\end{array}$ & \multirow[t]{2}{*}{$\begin{array}{l}\text { Short History of } \\
\text { Philosophy } \\
\text { Hirschberger } \\
\text { (1995), trans., from } \\
\text { 1995. as a textbook }\end{array}$} \\
\hline & & \multicolumn{3}{|c|}{$\begin{array}{l}\text { History of Philosophy Windelband (1956) trans., } \\
\text { as an additional textbook }\end{array}$} & \\
\hline \multirow{2}{*}{ 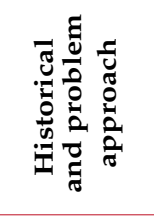 } & \multirow[t]{2}{*}{ - } & \multirow{2}{*}{\multicolumn{3}{|c|}{ - }} & $\begin{array}{c}\text { History of } \\
\text { Philosophy } \\
\text { Kalin (1995) }\end{array}$ \\
\hline & & & & & $\begin{array}{c}\text { Philosophy } \\
\text { Reškovac (2008) }\end{array}$ \\
\hline \multirow{2}{*}{ 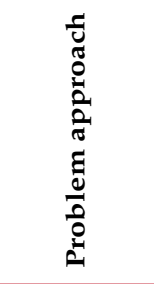 } & \multirow{2}{*}{$\begin{array}{c}\text { There were } \\
\text { books, but not } \\
\text { used as } \\
\text { textbooks. }\end{array}$} & \multirow{2}{*}{\multicolumn{3}{|c|}{-}} & $\begin{array}{l}\text { Introduction to } \\
\text { Philosophy } \\
\text { Anzenbacher } \\
\text { (1995), trans. }\end{array}$ \\
\hline & & & & & $\begin{array}{c}\text { Philosophy } \\
\text { Čehok and Grgić } \\
\text { (2001) }\end{array}$ \\
\hline
\end{tabular}

Our primary source is philosophy textbooks in Croatia written by Croatian authors, not translations of non-Croatian authors. These are excluded because they do not relate to the contents, the method of exposition, and the use of textbooks by Croatian authors (or at least, there is no proof of that). They are mentioned in Table 2 in the second column, second row, and in the first and fourth rows.

It is not completely known when the first philosophy textbook was written as a textbook in Croatia. Certainly, some histories of philosophy were used as textbooks, but it is not certain if they were written for that purpose. It is also interesting that there were quite high quality introductions to philosophy before 1945 (as well as to logic) but these books were never used as high school textbooks as far as we know (for example, books written by S. Zimmermann and other 
philosophers from that period). It is interesting that the first introduction to philosophy in the history of Croatian philosophy was written by Fran Trankvil Andreis (Tranquillus Andronicus Parthenius) in 1545, that is, Dialogue on should one philosophize? (Dialogus philosophandumne sit).

It is unknown to us what was used as a philosophy textbook in the period from 1945 to 1954, before Bošnjak et al. and his Anthology of philosophical texts. From 1954 to 1990, the situation was clear. The majority of textbooks were of a purely historical approach grounded in continental philosophy, with rare mention of some analytic philosophical schools and philosophers. Concerning the content of the major textbook in this period, History of philosophy with philosophical texts by B. Kalin, some remarks will be made hereafter. Consequently, the complete lack of the problem-based approach was obvious. The high school philosophy course was reduced to knowing by heart some major names, titles, quotes, and basic ideas.

In the 1990s, some changes were made. The historical approach continued to exist in newly translated textbooks (by (Hirschberger 1995)), and partly in new editions of Kalin. In his new editions, a short section on problems of philosophy was added to the still majority of the history of philosophy. The textbook by T. Reškovac Philosophy (Reškovac 2008) is generally recognized as a problem-based textbook, but the fact is that $90 \%$ of the book is texts of philosophers ordered in particular units to cover a particular topic. Therefore, formally speaking, this is a highly opinionated anthology of philosophical texts that perhaps, in practice, can be used for a problem-based approach, but the textbook itself is not such.

The purely problem-based approach textbooks are by A. Anzenbacher Introduction to philosophy (Anzenbacher 1995) and by I. Čehok and F. Grgić Philosophy (Čehok and Grgić 2001), although the first is a somewhat strange problem-based half-continental introduction, while the second is much more analytic approach-based. This is also the present situation.

Some major changes were made in the overall high school curriculum in Croatia and this will result in new philosophy textbooks, but it remains to be seen in which way these will be written. If one judges by analogy, say, with the high school Ethics textbook, there is not much to be hoped for. Namely, in the case of 16 authors of Ethics textbooks for high schools, only 3 had the minimal scientific qualifications to be authors, while 13 did not have any qualifications to be authors of textbooks (by qualifications, we mean internationally recognized conditions in terms of profession, experience, and scientific and pedagogical (methodical and didactical) results in terms of papers and books in respectable international journals and by such publishers). 
What is utterly strange is that, at the same time, the small Croatian philosophical community has internationally recognized authors of papers and books, that are extremely experienced and professional, but none of them are the author of any high school ethics textbook. By this analogy with ethics, one should be extremely optimistic in order to expect that the new textbooks will be of comparable international worth and quality (but let us give ourselves the opportunity to be completely astonished and shocked by the new philosophy textbooks). Therefore, this much on textbooks is sufficient for our present purpose.

\subsection{The Content of High School Textbooks in Croatia}

In this short section, we will present the results of our primary research on the Croatian high school philosophy textbooks content in the period 1965-2019 (as shown in Figure 1). Before 1945, there was no official textbook, but A. Bazala's History of Philosophy I-III (Bazala 1906, 1909, 1912) was used as a textbook.

After 1945, namely from 1954, there was one book (Bošnjak et al. 1954); there was no official textbook until 1965-History of philosophy with philosophical texts by N. Vejnović (Vejnović 1965) — which was replaced by History of philosophy with philosophical texts by B. Kalin in 1973 (Kalin 1973) and which is still used as a textbook in many new editions.

As mentioned, currently and in accordance with the new national curriculum philosophy course, new textbooks are being prepared.

It is remarkable how high school philosophy changed in only a few years (this stands not only for Croatia, but for all Eastern European countries from 1945 to 1990), namely that in a few years, the dominant philosophy even in high school became Marxist philosophy. In Table 3, in History of Philosophy, there was no substantial mention of Marxist philosophy, and in Anthology of philosophical texts (from 1954), there are 160 pages out of a total 537 on Marxist philosophy.

In Figure 1, only Croatian authors are given, because other textbooks are translations from previously published textbooks by international authors (as mentioned in Table 2, i.e., Windelband, Hirschberger, and Anzenbacher). Table 3 goes a bit more deeply into the textbooks by Croatian authors. It separates topics given in two major approaches in Croatian high school philosophy textbook traditions, namely historical and problem-based approaches. Therefore, in the columns, major authors are given and in the rows, the historical and problem parts of the listed textbooks. 


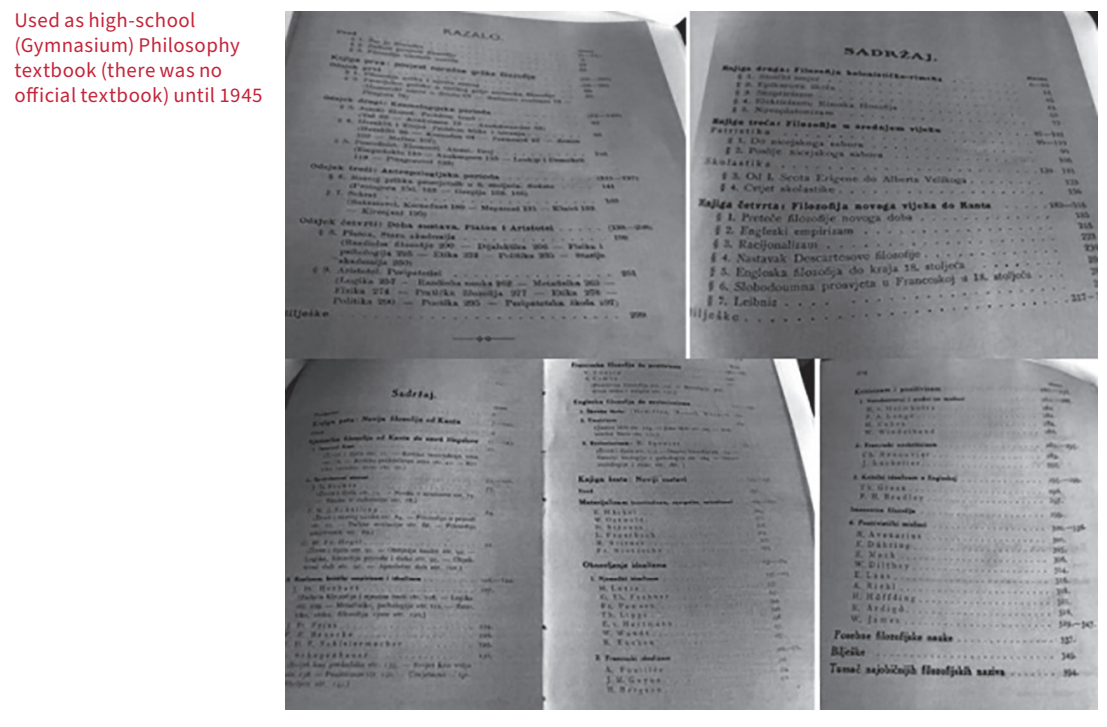

Albert Bazala (Bazala 1912), History of Philosophy I-III.

Philosophical
Interregnum

Used as a high-school (Gymnasium) Philosophy textbook from 1955 to 1965 , i.e. to Vejnović, N. (19651973) and later on Kalin, B. (1973 - until nowadays)

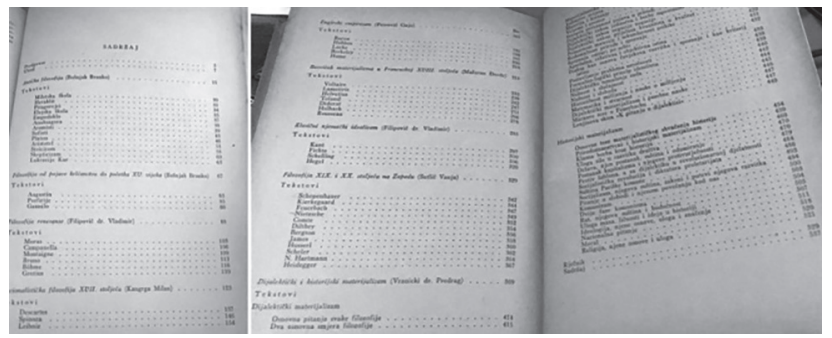

Bošnjak et al. (1954), Anthology of Philosophical Texts.

Figure 1. Comparison of contents between Bazala used as a philosophy course textbook until 1945 and Bošnjak et al. used after 1954.

The textbook by Kalin, which is still the longest approved textbook in the history of Croatian high school philosophy education, is given in five editions in order to show how it was changed, perhaps due to political, educational, and philosophical changes in Croatia and in Croatian philosophy before and after 1990-that is, the Croatian transition from a Yugoslav republic to an independent state and from a communist to a capitalist economy (it at least proclaimed to have done the latter). 
Concerning Table 3, abbreviations are the following:

- VEJ—Nevenka Vejnović (Vejnović 1965) History of philosophy with philosophical texts;

- KAL-Boris Kalin (Kalin 1973, 1995, 2001, 2008, 2015) History of philosophy with philosophical texts;

- $\quad$ ČEH-GRG-Ivan Čehok and Filip Grgić (Čehok and Grgić 2001) Philosophy;

- REŠ-Tomislav Reškovac (Reškovac 2008) Philosophy;

- $\quad+$-- - referring to whether the textbook has a chapter or a section on the mentioned topic;

- pp.-means number of pages of the topic (as shown in Table 3).

These abbreviations will be used in the interpretations of the results of the present research in order to make the interpretation shorter and clearer. All textbooks are written only in Croatian and by Croatian authors.

Interpretations of the results in Table 3 are quite limited, but they show some important features and tendencies, some of which are the following:

- There is an obvious difference between the historical- and problem-based approach between VEJ 1965 and KAL 1973 (and this approach lasted until the early 1990s concerning KAL) and ČEH-GRG 2001 and REŠ 2008 (although as previously said, formally speaking, REŠ 2008 is mostly an anthology of texts, but ordered in a way to be lectured in a problem-based manner).

- KAL, in its own series of editions, marked this change from a purely historical approach as in KAL 1973 to a mixed approach or historical- and problem-based approach from KAL 1995 until 2019. We can only speculate why this was done. It is possible that since the overall curriculum and plan and program of philosophy courses for high schools changed at the beginning of 1990s in terms of introducing the problem-based approach besides the purely historical approach, he wanted to cover the problem-based approach as well.

- There is also an obvious difference between the sections on Marxist philosophy which existed in VEJ 1965 and in KAL 1973, all the way until KAL 1995, when it miraculously vanishes. After almost 40 years, it was not so important to teach that Marxism is the only true philosophy in history (Kalin even wrote a textbook Marxism and socialist self-management in 1986 for students of non-gymnasium high schools).

- It is also significant how the size of the section on medieval philosophy expanded in KAL after the 1990s, since it dealt mostly with Christian philosophy that was regarded as overcome by Marxist philosophy. 
- Further on, some of the most prolific philosophical disciplines and problems of 20th century philosophy, such as the philosophy of language and philosophy of the mind, were not present at all in KAL before and after the 1990s, while they are present in ČEH-GRG and REŠ.

- Last but not least, a section on the history of Croatian philosophy was not there in KAL editions before 1990 and was present from editions from 1995 and later. This is not a minor objection, because Croatian philosophy spans almost to the Middle ages given that the first internationally recognized Croatian philosopher was Herman of Dalmatia (or Carinthia) (1100-1060), famous among many of his translations and astronomy works, and also for his ontological masterpiece $\mathrm{On}$ essences (De essentiis).

The general conclusion of Table 3 can be that Croatian high school philosophy textbooks throughout the period of 1965 to 2019 suffered a substantial change from purely historical-based approaches to mixed and purely problem-based approaches. Topics of practical philosophy (different from ethics), i.e., philosophy of technology, culture, and similar, as well as topics in popular philosophy that would be much more interesting to students (such as the philosophy of mobile phones, artificial intelligence, social networks, film, music, sports, etc.) are as well still waiting to enter textbooks (here, it is also interesting as in a few previous examples, among contemporary Croatian philosophers, there are experts for some fields of practical and popular philosophy, but they are, as far as we know, never invited to write something for such textbooks).

Here, perhaps similar to the conclusion from the Table 2 data, it could be concluded that we will have to wait and see how much the new textbooks will come closer to international standards, not only in terms of content and approach, but also in terms of topics of contemporary practical and popular philosophy.

- These textbooks seem to be completely useless concerning their applicability to many popular and cross-course topics, among which sustainable development is important. There is no useful relation of e.g., philosophical anthropology to biology, chemistry, geography, environment, climate, or sustainability. 
Table 3. High school philosophy textbooks in Croatia in the period 1965-2019.

\begin{tabular}{|c|c|c|c|c|c|c|c|c|}
\hline Topic & $\begin{array}{l}\text { VEJ } \\
1966\end{array}$ & $\begin{array}{l}\text { KAL } \\
1973\end{array}$ & $\begin{array}{l}\text { KAL } \\
1995\end{array}$ & $\begin{array}{l}\text { KAL } \\
2001\end{array}$ & $\begin{array}{l}\text { KAL } \\
2008\end{array}$ & $\begin{array}{l}\text { KAL } \\
2015\end{array}$ & $\begin{array}{l}\text { ČEH-GRG } \\
2001\end{array}$ & $\begin{array}{l}\text { REŠ } \\
2008\end{array}$ \\
\hline \multicolumn{9}{|l|}{ +/- Number of pp. } \\
\hline Intro. & $\stackrel{+}{7-10}$ & $\stackrel{+}{6-23}$ & $\begin{array}{c}+ \\
8-75 \\
\end{array}$ & $\begin{array}{c}+ \\
1-72 \\
\end{array}$ & $\begin{array}{c}+ \\
1-74 \\
\end{array}$ & $\stackrel{+}{9-77}$ & $\begin{array}{c}+ \\
11-22 \\
\end{array}$ & $\begin{array}{c}+ \\
10-42 \\
\end{array}$ \\
\hline History & 1 & $\begin{array}{c}+ \\
24-198\end{array}$ & $\stackrel{+}{+}$ & $\begin{array}{c}+ \\
75-250 \\
\end{array}$ & $\begin{array}{c}+ \\
75-250 \\
\end{array}$ & $\begin{array}{c}+ \\
78-353 \\
\end{array}$ & $\begin{array}{c}+ \\
22-31 \\
\end{array}$ & $\begin{array}{c}+ \\
43-45 \\
\end{array}$ \\
\hline - Greece and Ro. & & $\begin{array}{c}+ \\
26-59 \\
\end{array}$ & $\begin{array}{c}+ \\
78-112 \\
\end{array}$ & $\stackrel{+}{75-108}$ & $\stackrel{+}{+}+$ & $\begin{array}{c}+ \\
78-135 \\
\end{array}$ & $\begin{array}{c}+ \\
26-28 \\
\end{array}$ & $\begin{array}{c}+ \\
43-44 \\
\end{array}$ \\
\hline - Medieval & & $\begin{array}{c}+ \\
60-79\end{array}$ & $\begin{array}{c}+ \\
113-133\end{array}$ & $\begin{array}{c}+ \\
110-130\end{array}$ & $\begin{array}{c}+ \\
110-132\end{array}$ & $\begin{array}{c}+ \\
137-169\end{array}$ & $\begin{array}{c}+ \\
28-29\end{array}$ & $\begin{array}{c}+ \\
44 \\
107-113\end{array}$ \\
\hline - Modern & & $\begin{array}{c}+ \\
80-143\end{array}$ & $\begin{array}{c}+ \\
134-197 \\
\end{array}$ & $\begin{array}{c}+ \\
113-193\end{array}$ & $\begin{array}{c}+ \\
133-194 \\
\end{array}$ & $\begin{array}{c}+ \\
170-259\end{array}$ & $\begin{array}{c}+ \\
30 \\
\end{array}$ & $\begin{array}{c}+ \\
44-45\end{array}$ \\
\hline - Contemporary & $\begin{array}{c}+ \\
95-112\end{array}$ & $\stackrel{+}{144-198}$ & $\begin{array}{c}+ \\
198-230 \\
401-403\end{array}$ & $\begin{array}{c}+ \\
195-250\end{array}$ & $\begin{array}{c}+ \\
195-250\end{array}$ & $\begin{array}{c}+ \\
260-353\end{array}$ & $\begin{array}{c}+ \\
31\end{array}$ & $\begin{array}{c}+ \\
45\end{array}$ \\
\hline Marxist & $\begin{array}{c}+ \\
85-94 \\
112-119\end{array}$ & $\begin{array}{c}+ \\
147-162 \\
183-198\end{array}$ & - & - & - & - & - & - \\
\hline Ontology & - & - & $\begin{array}{c}+ \\
22-30 \\
\end{array}$ & $\stackrel{+}{16-23}$ & $\stackrel{+}{+}$ & $\begin{array}{c}+ \\
21-27 \\
\end{array}$ & $\begin{array}{c}+ \\
92-129 \\
\end{array}$ & $\begin{array}{c}+ \\
46-79\end{array}$ \\
\hline Epistemology & - & - & $\begin{array}{c}+ \\
42-51\end{array}$ & $\begin{array}{c}+ \\
37-46\end{array}$ & $\begin{array}{c}+ \\
37-46\end{array}$ & $\begin{array}{c}+ \\
39-47\end{array}$ & $\begin{array}{c}+ \\
43-70\end{array}$ & $\begin{array}{c}+ \\
118-193\end{array}$ \\
\hline Ethics & - & - & $\begin{array}{c}+ \\
52-58 \\
\end{array}$ & $\begin{array}{c}+ \\
47-55 \\
\end{array}$ & $\begin{array}{c}+ \\
47-55 \\
\end{array}$ & $\begin{array}{c}+ \\
48-56 \\
\end{array}$ & $\begin{array}{c}+ \\
144-173 \\
\end{array}$ & $\begin{array}{c}+ \\
222-293\end{array}$ \\
\hline Phil. of science & - & - & $\begin{array}{c}+ \\
16-21\end{array}$ & $\begin{array}{c}+ \\
8-13 \\
\end{array}$ & $\begin{array}{c}+ \\
8-13 \\
\end{array}$ & $\begin{array}{c}+ \\
16-18 \\
\end{array}$ & - & $\begin{array}{c}+ \\
38-40 \\
\end{array}$ \\
\hline Anthropology & - & - & $\begin{array}{c}+ \\
31-41 \\
\end{array}$ & $\begin{array}{c}+ \\
24-36 \\
\end{array}$ & $\begin{array}{c}+ \\
24-36 \\
\end{array}$ & $\begin{array}{c}+ \\
28-35 \\
\end{array}$ & $\begin{array}{c}+ \\
32-43 \\
\end{array}$ & $\begin{array}{c}+ \\
396-421\end{array}$ \\
\hline Phil. of religion & - & - & - & - & - & - & - & $\begin{array}{c}+ \\
40 \\
\end{array}$ \\
\hline Phil. of language & - & - & - & - & - & - & $\begin{array}{c}+ \\
72-91 \\
\end{array}$ & - \\
\hline Phil. of mind & - & - & - & - & - & - & $\begin{array}{c}+ \\
130-143\end{array}$ & $\begin{array}{c}+ \\
194-221\end{array}$ \\
\hline Political phil. & - & - & $\begin{array}{c}+ \\
66-70 \\
\end{array}$ & $\begin{array}{c}+ \\
63-68 \\
\end{array}$ & $\begin{array}{c}+ \\
56-61 \\
\end{array}$ & $\begin{array}{c}+ \\
57-65 \\
\end{array}$ & $\begin{array}{c}+ \\
174-188\end{array}$ & $\begin{array}{c}+ \\
294-355\end{array}$ \\
\hline Phil. of art & - & - & $\begin{array}{c}+ \\
59-65\end{array}$ & $\begin{array}{c}+ \\
56-62 \\
\end{array}$ & $\begin{array}{c}+ \\
62-68 \\
\end{array}$ & $\begin{array}{c}+ \\
66-73 \\
\end{array}$ & $\begin{array}{c}+ \\
220-238 \\
\end{array}$ & $\begin{array}{c}+ \\
\text { 356-395 }\end{array}$ \\
\hline \multirow[t]{2}{*}{ Other topics } & $\begin{array}{c}\text { phil. } \\
\text { texts: } \\
123-314\end{array}$ & $\begin{array}{l}\text { phil. } \\
\text { texts: } \\
203-387\end{array}$ & $\begin{array}{c}\text { overview } \\
\text { of Cro } \\
\text { phil.: } \\
397-400 \\
\end{array}$ & $\begin{array}{c}\text { overview } \\
\text { of Cro } \\
\text { phil.: } \\
253-271 \\
\end{array}$ & $\begin{array}{c}\text { overview } \\
\text { of Cro } \\
\text { phil.: } \\
253-271\end{array}$ & $\begin{array}{c}\text { overview } \\
\text { of Cro } \\
\text { phil.: } \\
358-370\end{array}$ & $\begin{array}{c}\text { theology: } \\
190-219\end{array}$ & $\begin{array}{l}\text { theology: } \\
80-117\end{array}$ \\
\hline & & & $\begin{array}{l}\text { phil.texts: } \\
237-394\end{array}$ & $\begin{array}{l}\text { phil.texts: } \\
273-400\end{array}$ & $\begin{array}{l}\text { phil.texts: } \\
273-400\end{array}$ & & & \\
\hline
\end{tabular}




\section{Conclusions and Further Research}

As said in the introduction, the basic goal of this text was to present the general directions for substantial changes in high school philosophy courses or courses in terms of the future research plan.

\subsection{Conclusions}

Let us start with a few modest and quite limited conclusions that can be drawn from the previous sections.

- In the 1st part, it was shown that there is a theoretical or particularly philosophical background and justification for the substantial changes in high school philosophy courses via the introduction of methods and topics of popular philosophy.

- In the 2nd part, it was shown that principle guidelines for remodeling the existing curriculum or the slightly improved one are possible and useful.

- In the 3rd part, it was shown that no substantial change in the level of high school philosophy textbooks was made. The only change in last three decades of the history of philosophy textbooks in Croatia was the gradual change from the historical- to the problem-based approach (similar to the results that were made in the Italian reform in the early 2000s).

The overall idea of the text, i.e., to set some parameters for future research, was set at least in terms of basic guidelines that made it possible to formulate the starting research questions and hypothesis for future research and possible implementation if the research ends successfully. Concerning implementation, something that was not performed properly by officials in Croatia, all the elements of the research even before the plan for experimental implementation should be tested among high school students and this is also included in this research plan.

- An application for sustainable development education: Philosophy courses in high school can and should serve as a self-created axis of rotation that can glue together many important issues of today's youth around the world, one of which is surely the topic of sustainable development. Teaching sustainable development from the philosophical perspective, as theoretical clarity of concepts and clear and reasonable actions in practical daily lives, could serve the purpose of sustainable development. The philosophy would not lose any of its mysteriousness and it would become, at the same time, quite useful to students, given alongside the tools for rational, critical, and tolerant dialogue and for reaching reasonable 
consensus on issues of collective actions, especially related to the issues of sustainable living and development.

In terms of the research questions of the future research, as a result of the analysis conducted here, some are evidently immensely important if one has the interest and well-being of students and their future education after they have finished high school (it does not matter for the present purposes if this education will be formal or informal).

The research questions would be the following:

- (1) What is popular philosophy, how does it relate to non-popular philosophy, does it have substantially different subtypes, and how does it reflect the interests of high school students?

- (2) If question (1) is affirmatively and applicably answered, is it possible to remodel the possible curriculum of the high school philosophy course in order to include popular philosophy?

- (3) If questions (1) and (2) are affirmatively answered, is it possible to research the students' perceptions of the proposed changes in the teaching of the philosophy course (say, by a survey) and how important would the results of such research be for the implementation of the remodeled high school curriculum of philosophy?

\subsection{Further Research}

Given that this whole text is the proposal of a future research plan, the research is the next step; however, in a much stricter and more detailed manner than it was presented here. Additionally, two aspects need to be achieved in the future. First, a close examination of all relevant scientific, pedagogical, methodical, and didactic research relevant to this topic is required. Second, results of the practical application of existing curricula in Croatia and in sufficiently similar educational high school systems (especially in the EU) is needed. After all, the basic idea of this future research proposal is to connect the high school philosophy course with popular phenomena interesting to students, and to connect it to other courses as much as possible in order to point to the fact that philosophical problems, clearly being abstract, can be and are specific and connected with the daily interests and routines of students. No philosophy course is an island. At best, they are peninsulas, naturally more or less substantially connected not just to other high school courses, but to students' daily life as well. It is time to show this. 
Author Contributions: Conceptualization, K.K. and M.M.; Methodology, K.K.; Formal Analysis, M.M.; Original Draft Preparation, M.M.; Writing, Review \& Editing, K.K. and M.M.; Both authors revised and submitted the final version of the text. All authors have read and agreed to the published version of the manuscript.

Acknowledgments: If it all goes well Matišić will conduct all the elements of the proposed research plan explicated in this paper during her doctoral study research and present them in her dissertation which is researched under the mentorship by Krkač. As far as some signals are sent from Croatian Ministry of Science and current minister B. Divjak in terms of future improvements of high school curricula and methods, we hope that some of these ideas and future research will find their way to be parts of future modifications of the Croatian high-school system. We are thankful to philosophers Erna Banić-Pajnić for pointing to some valuable sources during our research, to Damir Mladić for reviewing the text, and to Nina Alvir, MBA for proofreading the text.

Conflicts of Interest: The authors declare no conflict of interest.

\section{References}

Anzenbacher, Arno. 1995. Introduction to Philosophy. Zagreb: Školska Knjiga.

Bazala, Albert. 1906. History of Philosophy I. Zagreb: Matica Hrvatska.

Bazala, Albert. 1909. History of Philosophy II. Zagreb: Matica Hrvatska.

Bazala, Albert. 1912. History of Philosophy III. Zagreb: Matica Hrvatska.

Blaut, James Morris. 1993. The Colonizer's Model of the World, Geographical Diffusionism and Eurocentric History. New York and London: The Guilford Press.

Bošnjak, Branko, Vladimir Filipović, Milan Kangrga, Damir Mažuran, Gajo Petrović, Vanja Sutlić, and Predrag Vranicki. 1954. Anthology of Philosophical Texts. Zagreb: Školska Knjiga.

Butterfield, Jeremy, and John Earman, eds. 2007. Philosophy of Physics. Handbook of the Philosophy of Science. Amsterdam and Oxford: Elsevier.

Čehok, Ivan, and Filip Grgić. 2001. Philosophy. Zagreb: Profil.

Falzon, Christopher. 2002. Philosophy Goes to the Movies, An Introduction to Philosophy. London and New York: Routledge.

For Beginners Books, Philosophy \& Literature. 2019. Available online: https://www. forbeginnersbooks.com/philosophy-literature-for-beginners (accessed on 6 June 2019).

Gracyk, Theodore, and Andrew Kania, eds. 2011. The Routledge Companion to Philosophy and Music. London and New York: Routledge.

Hagberg, Garry L., and Jost Walter, eds. 2010. A Companion to the Philosophy of Literature. Blackwell Companions to Philosophy. Chichester: Wiley-Blackwell, John Wiley \& Sons. Heaton, John, and Judy Groves. 2003. Wittgenstein for Beginners. Zagreb: Naklada Jesenski i Turk. Hirschberger, Johannes. 1995. Short History of Philosophy. Zagreb: Školska Knjiga.

International Philosophy Olympiad. 2019. Available online: http://www.philosophy-olympiad. org/ (accessed on 28 May 2019). 
Jacoby, Henry, ed. 2009. House and Philosophy: Everybody Lies. The Blackwell Philosophy and Pop Culture Series; Hoboken: Wiley, John Wiley \& Sons, Inc.

Jalšenjak, Borna, and Kristijan Krkač, eds. 2012. Društveno Odgovorno Poslovanje [Social Responsible Business]. Zagreb: MATE, ZSEM.

Jalšenjak, Borna, and Kristijan Krkač. 2018a. Reintroducing Disputations as a possible way to practice critical thinking. In Quality and Governance in Higher Education, Opening New frontiers, 6th Higher Education Institutions Conference. Edited by Karmela Aleksić-Malslać and Philip Vranešić. Zagreb: Mate, pp. 64-69.

Jalšenjak, Borna, and Kristijan Krkač. 2018b. Teaching business ethics in transitional cultures. An example of practice at Zagreb School of Economics and Management. In Management Education for Corporate Social Performance. Edited by Agatha Stachowicz-Stanusch and Wolfgang Amann. Charlotte: Information Age Publishing, pp. 33-51.

Jarvie, Ian C. 2003. Philosophy of the Film: Epistemology, Ontology, Aesthetics. London and New York: Routledge.

Kalin, Boris. 1973. History of Philosophy with Philosophical Texts. Zagreb: Školska Knjiga.

Kalin, B. 1995. History of Philosophy with Philosophical Texts, 19tn ed. Zagreb: Školska knjiga.

Kalin, B. 2001. History of Philosophy with Philosophical Texts, 25th ed. Zagreb: Školska knjiga.

Kalin, B. 2008. History of Philosophy with Philosophical Texts, 30th ed. Zagreb: Školska knjiga.

Kalin, B. 2015. Philosophy-Introduction and History, 2nd ed. Zagreb: Školska knjiga.

Kivy, Peter, ed. 2004. The Blackwell Guide to Aesthetics. Blackwell Philosophy Guides. Oxford: Blackwell Publishing.

Krkač, Kristijan. 2010. Filozofija Nogometa [Philosophy of Football]. Zagreb: Naklada Jesenski i Turk.

Krkač, Kristijan. 2013. Krava na Mjesecu, Filozofija Znanstveno-Fantastičnih/Horor Filmova [Cow on the Moon, Philosophy of Science-Fiction/Horror Films]. E-Book. Zagreb: Udruga za Promicanje Filozofije Filozofija.org.

Krkač, Kristijan, and Iva Cerovsky. 2012. On topics, quantity, and quality of philosophizing among Croatian philosophers, [originally in Croatian: O čemu, koliko i kako filozofiraju hrvatski filozofi?]. Obnovljeni Život 67: 479-94.

Krkač, Kristijan, and Borna Jalšenjak, eds. 2015. Uvod u Filozofiju i Kritičko Mišljenje [Introduction to Philosophy and Critical Thinking], 2nd ed. Zagreb: MATE, ZSEM.

Krkač, Kristijan, and Borna Jalšenjak, eds. 2016. Poslovna Etika, Korporacijska Društvena Odgovornost i Održivost [Business Ethics, Corporate Social Responsibility and Sustainability], 2nd ed. Zagreb: MATE, ZSEM.

Lorand, Ruth. 2003. Aesthetic Order: A Philosophy of Order, Beauty and Art. London and New York: Routledge.

McIntyre, Lee, and Alex Rosenberg, eds. 2017. The Routledge Companion of Philosophy of Social Science. London and New York: Routledge.

McLaughlin, J., ed. 2005. Comics as Philosophy. Jackson: University Press of Mississippi. 
Ministry of Science and Education, National Curriculum for Gymnasium Education. 2017. Available online: https://mzo.hr/hr/nacionalni-kurikulumi (accessed on 7 June 2019).

Ministry of Science and Education, National Curriculum for the High-School Philosophy Course. 2017. Available online: https://mzo.hr/sites/default/files/dokumenti/2017/OBRAZOVANJE/ NACION-KURIK/PREDMETNI-KURIK/filozofija.pdf (accessed on 27 May 2019).

Open Court Popular Culture and Philosophy Series. 2019. Available online: http://www. opencourtbooks.com/categories/pcp.htm (accessed on 3 June 2019).

Painter-Morland, Mollie, Geert Demuijnck, and Sara Ornati. 2017. Sustainable Development and Well-Being: A Philosophical Challenge. Journal of Business Ethics 146: 295-311. [CrossRef]

Papuziński, Andrzej, and Artur Pawłowski. 2007. The Philosophy of Sustainable Development as A Subdiscipline of Philosophical Research. Problems of Sustainable Development 2: 27-40.

Philosophy Education. 2019. Available online: https:/en.wikipedia.org/wiki/Philosophy_ education (accessed on 1 June 2019).

PISA Worldwide Ranking-Average Score of Math, Science and Reading-FactsMaps. 2019. Available online: http://factsmaps.com/pisa-worldwide-ranking-average-score-of-mathscience-reading/ (accessed on 27 May 2019).

Reškovac, Tomislav. 2008. Philosophy. Zagreb: Profil.

Svendsen, Lars. 2006. Fashion: A Philosophy. London: Reaktion Books.

The Blackwell Philosophy and Pop Culture Series. 2019. Available online: https: //andphilosophy.com/books/ (accessed on 3 June 2019).

UNESCO. 2007. Philosophy: A School of Freedom. Teaching Philosophy and Learning to Philosophize: Status and Prospects. Paris, France: UNESCO, Available online: https://unesdoc.unesco. org/ark:/48223/pf0000154173 (accessed on 4 June 2019).

Vejnović, Nevenka. 1965. History of Philosophy with Philosophical Texts. Zagreb: Školska Knjiga. Wartenberg, Thomas E., and Cynthia A. Freeland, eds. 1995. Philosophy and Film. London and New York: Routledge.

Widdows, Heather. 2018. Perfect Me: Beauty as an Ethical Ideal. Princeton and Oxford: Princeton University Press.

Windelband, Wilhelm. 1956. History of Philosophy. Zagreb: Naprijed.

Wittgenstein, Ludwig. 1998. Philosophical Investigations. Zagreb: Nakladni zavod Globus.

Wittkower, Dylan E., ed. 2010. Facebook and Philosophy: What's on My Mind? Popular Culture and Philosophy. Chicago and La Salle: Open Court.

Wolfendale, Jessica, and Jeanette Kennett. 2011. Fashion-Philosophy for Everyone: Thinking with Style. Chichester: Wiley-Blackwell, John Wiley \& Sons.

(C) 2021 by the authors. Licensee MDPI, Basel, Switzerland. This article is an open access article distributed under the terms and conditions of the Creative Commons Attribution (CC BY) license (http://creativecommons.org/licenses/by/4.0/). 


\section{An Argumentation Practice Based on STEAM for the Chemistry Education of Gifted}

\section{Gulseda Eyceyurt Turk}

\section{Introduction}

With the dizzying changes and developments of the 21st century, STEM education first started in the United States to gain an advantageous position in the global market by educating qualified high school and college graduates who are adapting to these innovations (Breiner et al. 2012). The acronym of STEM means teaching and learning in the fields of science, technology, engineering, and mathematics. It usually includes educational activities for the integration of these disciplines with each other in each stage of education (Gonzalez and Kuenzi 2012). According to Sanders (2009), STEM is defined as inquiry and design for solutions to students' problems in daily life or areas of their interest by integrating technological design with scientific research.

The STEM educational policy took place rapidly in educational environments, but some experts in the art community and beyond have suggested that art should be integrated into this combination to make the combination of science, technology, engineering, and mathematics stronger (Robelen 2011). In addition, traditional STEM degrees focus on convergent skills, whereas art degrees focus on divergent skills (Land 2013). In history, a sharp distinction between disciplines has not been made since the ancient Greeks. From this point of view, if a synergetic balance is established between art and science, it is needed to provide this integration (Piro 2010). Thus, it could be said that the transition period from STEM to STEAM started in enhancing the education platform to better prepare students for both analytical and creative thinking (Land 2013).

It would be useful to underline that the science, technology, engineering, arts, and mathematics (STEAM) amalgamation is not a teaching method; it is just an educational guide. Therefore, a proper teaching method must be selected for the STEAM process. Argumentation, which is based on inquiring and criticizing processes, could be offered as a proper teaching method for STEAM education. Argumentation is conducted in effective speech communication to improve critical thinking (West 1994). Argumentation is also "the coordination of evidence and theory to support or refute an explanatory conclusion, model, or prediction" (Suppe 1998, 
cf., Osborne et al. 2004, p. 995). Engaging students with an argumentation process requires the use of an argument pattern. A basic argument pattern from the literature could be given as Walton's proposal (Walton 2006). Walton proposed using three premises to justify a conclusion as an argument pattern.

On the other hand, for nearly a century, scholars have sought to understand, measure, and explain giftedness. Giftedness is the manifestation of performance that is clearly at the upper end of the distribution in a talent domain, even relative to other high-functioning individuals in that domain (Subotnik et al. 2011); therefore, the education of gifted students requires some characteristics. First, gifted students need a daily challenge in their specific areas of interest. Second, opportunities should be given to gifted students to work independently in their areas of interest and talent. Third, subject-based and grade-based acceleration must be provided to gifted students according to their educational needs. Fourth, gifted students' socialization and learning needs with their like-ability peers must be taken into consideration too. Fifth, for specific curriculum areas, instructional delivery must be differentiated (Rogers 2007). For differentiating instructional delivery, by transferring higher-level lesson contents to the current class and using the remaining time by narrowing the subjects for different topics, students' independent longitudinal studies on the topic of their interests and summer programs running after the school term could be offered as programming options-in other words, enrichment.

In the literature, for differentiating gifted students' learning domains, especially in chemistry education, it was suggested to construct teaching domains giving the chance to gifted students to learn by experiencing in order to enhance their critical and upper-cognitive thinking (Taber 2010; Umar 2017). Demircioglu et al. (2012) utilized context-based learning on acid-base topic for improving gifted students' meaningful concept learning as an enrichment study. In other enrichment research, the 5E model was utilized on a change of matter subject for correcting gifted students' misconceptions of the same subject; a common knowledge construction model was utilized on acid-base subject for helping gifted students develop positive attitudes towards lessons (Demircioglu et al. 2014, 2016; Demircioglu and Vural 2016).

However, in the national literature, there are also chemistry enrichment argumentation studies based on different teaching activities such as "living statues", "prototype constructions", "black box experiments", "case studies", "forensic chemistry experiments", and "chemistry-toxicology experiments". In an argumentation-based living statues study, a teacher of gifted students, who is also an international living statue, and her daughter modeled Marie Curie and her daughter Irene as living statue performances. Another teacher of gifted students conducted 
the argumentation process for gifted students, based on living statues' historical science stories for teaching the students the nature of science. The gifted students' pre- and post-drawings showed that their nature of science images improved as "The scientists could be woman too", "Science requires a teamwork; science could not be done alone", and "The scientists could gain knowledge through argumentation too; not only gain through experiments" (Akyol and Tüzün 2020). Harut et al. (2019) made gifted students model "Prof. Dr. Fuat Sezgin's prototypes" in their research. After modeling the prototypes, the gifted students criticized the prototypes' functions by constructing arguments. The research's results showed that not only the gifted students' critical thinking was improved by enhancing their argument construction skills but also their recognition of an internationally famous scientist (Prof. Dr. Fuat Sezgin) was improved by modeling his prototypes. Tüzün and Tüysüz (2019a) researched gifted students' critical thinking skills through a black box experiment arguing process. First, the gifted students argued the black box experiments, and then they had the chance to criticize their own thinking processes through conducting the experiments again but this time without black boxing. Therefore, the gifted students' critical thinking skills were improved as a result of the study. In a study for encouraging gifted students to criticize chemistry through an online enrichment application, forensic chemistry/science case studies were used. The gifted students argued each of the seven case studies in an online argumentation process, and through the process, the gifted students could justify their claims by evidence and warrants, or they rebutted the others' claims by counter-claims and counter-warrants. The study enhanced the gifted students' critical thinking with the help of making them construct arguments and counter-arguments in an online argumentation process (Tüzün and Tüysüz 2019b). In another study making gifted students conduct forensic chemistry experiments/forensic analysis and then argue the analysis' result, the gifted students' argument construction skills were improved, as well as their critical thinking skills (Tüysüz and Tüzün 2019). According to national ethical standards, daphnia is a microscopic organism allowed for use in experiments at schools. Tüzün and Tüysüz (2019c) made gifted students study the environmental effects on daphnia as another enrichment study. The gifted students investigated the organism's heart beat number per ten seconds in a drop of water under a microscope because the organism is glassy. Then, the students investigated the organism's heart beat number per ten seconds in a drop of vinegar assimilating an acid rain-exposed environment under a microscope. The heart beat number per ten seconds was multiplied by six for transmuting the number per minute. This was to ensure the organism did not suffer and could continue its life. The gifted students 
argued the difference between the heart beat numbers in water and in vinegar environments on the basis of toxicology. Not only the gifted students' argument construction skills were improved by this research but also a very different teaching domain was modeled for further international researchers. However, there are no chemistry enrichment studies in the literature about argumentation practice based on STEAM. Therefore, in this study, it was aimed to construct a chemistry enrichment argumentation practice based on STEAM. Here, it would be useful to explain why the discipline was chosen as chemistry because some students are not able to learn chemistry properly due to its submicroscopic nature (Nakhleh 1992). Therefore, in appropriate argumentation-based teaching domains, students could learn the basic concepts by arguing them, through improving their argument construction skills. More specifically, it was aimed to enhance gifted students' argumentation skills by making them complete the missing part of a chemistry animation scenario based on STEAM and then reconstruct it as an argument as an enrichment in this study. It was also aimed to fill the gap in the literature with the help of this study. The research question was constructed as "How could argumentation skills of gifted students be enhanced by an argumentation practice based on STEAM?" The significance of the study could be stated as being a guide for educators studying in the field of education of the gifted for offering alternative programming options with the help of this "argumentation practice based on STEAM" study's detailed description. On the other hand, constructing a guide for educators studying in the field of education of the gifted for offering alternative programming options with the help of argumentation practice is so important because according to Kopnina (2020), for sustainable development and education, critical pedagogy, which formed the basis of the current study, is so important too. As UNESCO (2017) emphasized, it is needed to change the way individuals think and act. This requires quality education and learning for sustainable development at all levels and in all social contexts, which were also the current study's target too (cf. Hofman-Bergholm 2020).

\section{Materials and Methods}

\subsection{Theoretical Framework: Case Study}

This study employed a case study as the theoretical framework. "For the most part, the cases of interest in education and social service are people and programs. Each one is similar to other people and programs in many ways and unique in many ways. We are interested in them for both their commonality and uniqueness. We seek to understand them. We would like to hear their stories" (Stake 1995, p. 1). This framework is especially suited for this study since the case of interest is 
"completing the missing parts of chemistry animation scenarios based on STEAM and reconstructing them as arguments" as a programming option, and "the effect of the program on gifted students' concept images and argumentation skills" as the influence on the people dimension.

\subsection{Setting and Participants}

The study was conducted with 12 gifted students at a school for the gifted in Ankara province in Turkey. The context of the study was a workshop for the gifted which gave an opportunity to investigators to construct an independent enrichment domain for the chemistry education of the gifted. A workshop group of 12 students met for two hours per week for four weeks, totaling an eight-hour period for this study. The willingness of the gifted students for this enrichment was the criterion for the determination of the participants of this study. Six participants were female, and the other six participants were male.

\subsection{Instruments}

Seven different worksheets were used as data collection tools. In each of the worksheets, first, gifted students were asked to draw the missing part of each chemistry animation scenario and then to criticize their drawings as arguments on the basis of Walton's (2006) argument pattern components, consisting of a conclusion with three premises; in other words, justifying a claim with three different warrants. The worksheets are provided in Table 1.

The instruments' content validity was checked by two experts in science education. The instruments' reliability was guaranteed by the same educators' coding and categorizing consistency through the data analysis process.

\subsection{Data Collection Process}

Before the application process, STEAM, chemistry animation scenarios, argumentation, and argument concepts were explained to the gifted students. Then, chemistry animation scenarios, each with a missing part, were given to the students. The students argued each of the chemistry animation scenarios in small groups. They criticized their own and others' thinking strategies through these small group discussions about the chemical concepts for constructing scientifically proper images about the concepts in their mental schemes. Additionally, they then individually drew the missing parts of the chemistry animation scenarios. At the end, they individually reconstructed their drawings as arguments on the basis of Walton's (2006) argument pattern components of conclusion, premise, premise, and premise. 
Table 1. The worksheets of the study.

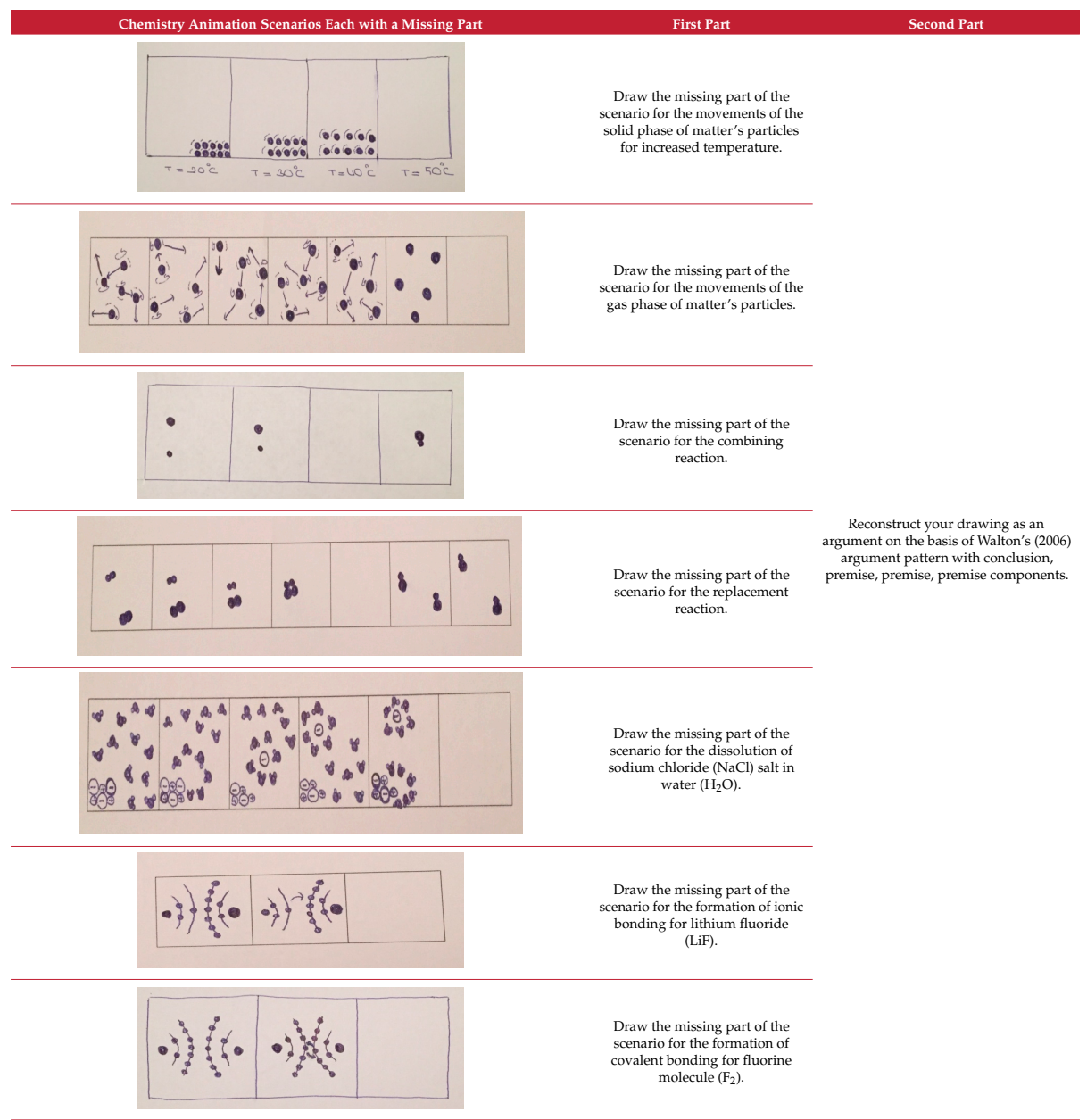

\subsection{Data Analysis}

Content analysis was utilized for the gathered data.

First, the gifted students' drawings were coded, and then categories were constructed and frequency-percentage calculations were performed. Additionally, students' arguments were coded on the basis of Walton's (2006) argument pattern components of conclusion-premise-premise-premise only if the arguments were scientifically correctly constructed by the gifted students. The categories were formed 
with the arguments' existing code combinations; frequency-percentage calculations were performed.

For the data collection tools' content validity, two researchers checked the data collection tools. For the data collection tools' reliability, two different researchers coded and categorized the gathered data; whenever their analyses contradicted each other, they came to an agreement by recoding and recategorizing. Using two different independent researchers for coding and categorizing also provided the study's researcher triangulation for validity. Additionally, making students draw the missing parts of the chemistry scenarios and reconstruct the scenarios as arguments provided data triangulation for validity. For qualitative research, triangulations are very important for validity of the research.

Additionally, in this study, in accordance with the STEAM pedagogy, the students were exposed to chemical problems such as finding solutions for missing parts of scenarios and then, as the art part, drawing the missing parts. Therefore, before reconstructing the chemistry scenarios as arguments, an application was put forth on the basis of the STEAM philosophy.

\section{Results}

\subsection{The Gifted Students' Drawings Analysis}

The gifted students' drawings for the missing parts of each animation scenario were coded, categories were constructed, and frequency-percentage calculations were performed. The findings are shown in Table 2.

In Table 2, it can be seen that for the first animation scenario, $100 \%$ of the gifted students could draw the missing part of it scientifically correctly. For the second, third, fourth, fifth, sixth, and last animation scenarios, 75\%, 100\%, 100\%, 92\%, 75\%, and $92 \%$ of the gifted students could draw the missing part of the animation scenarios scientifically correctly, respectively. Therefore, the gifted students' drawings analysis showed that they were able to mentally construct proper concept images after small group discussions. 
Table 2. Analysis of the gifted students' drawings.

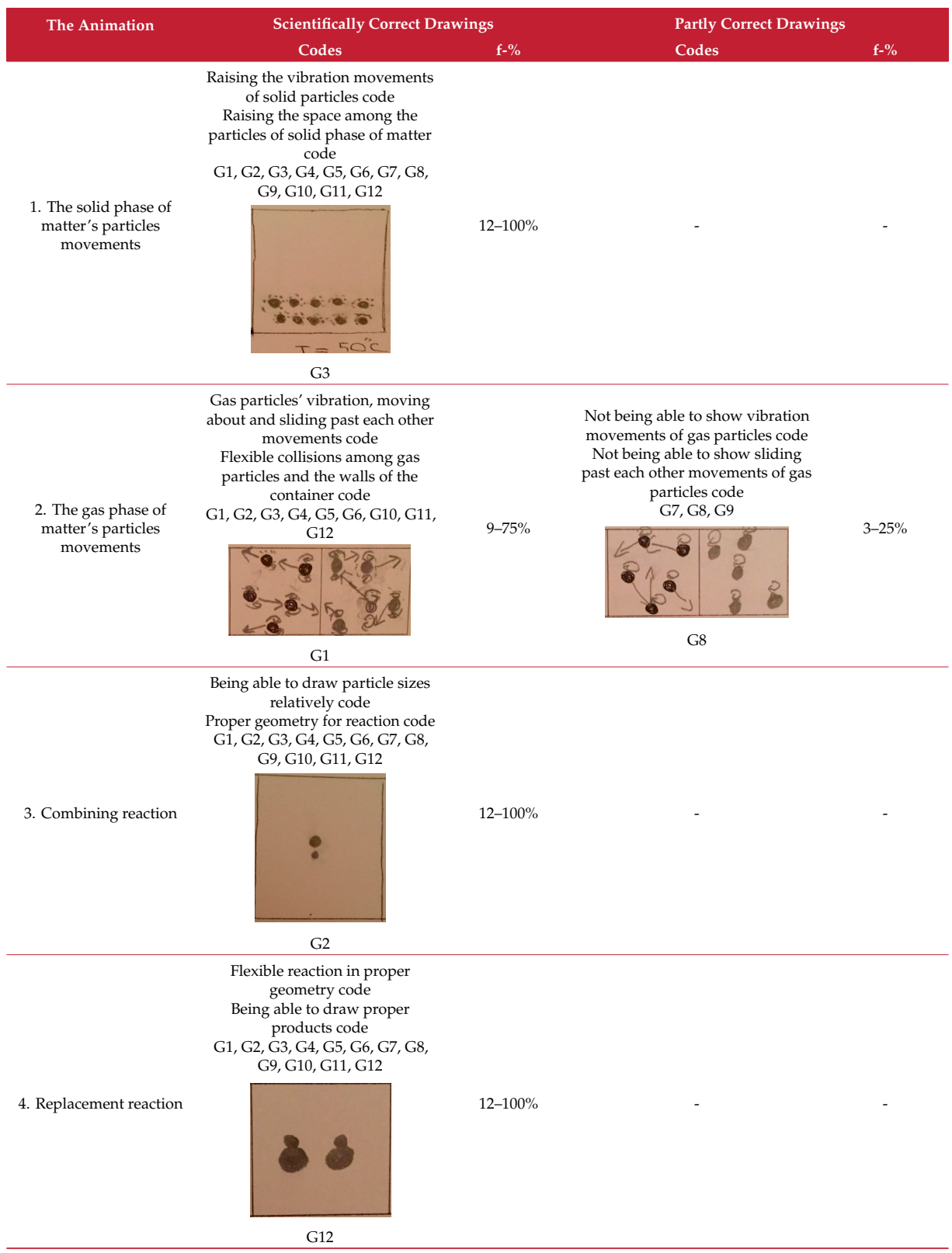


Table 2. Cont.

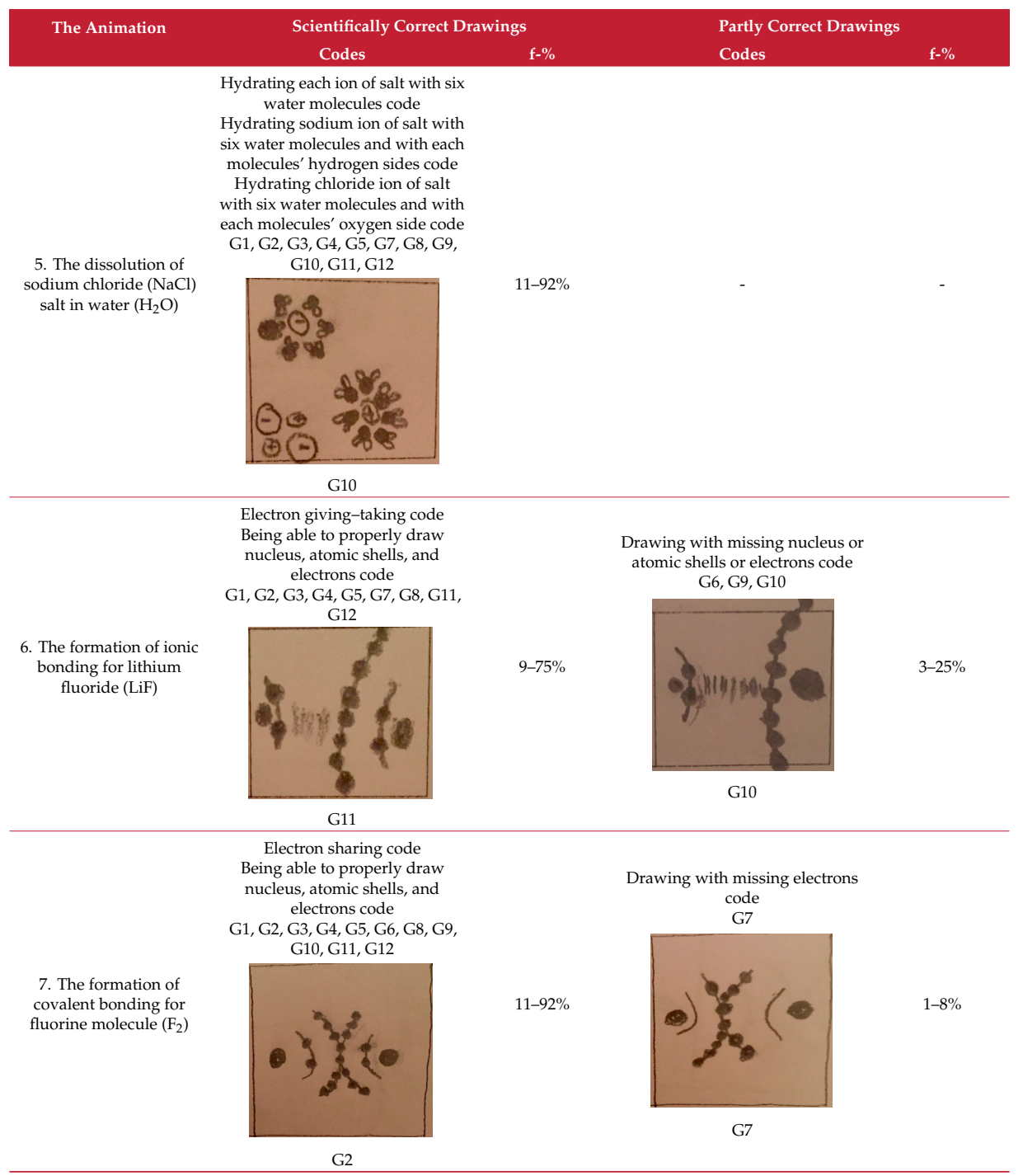

In Table 2, frequency is shown by $\mathrm{f}$ and percentages by \%. For each of the categories, the students" drawings are shown by G, G for the shortening of "gifted student". For each of the categories, illustrations from students' drawings are shown too. Additionally, as can be seen in the table, a gifted student did not produce a drawing for the fifth animation scenario's missing part. 


\subsection{The Gifted Students' Arguments Analysis}

The gifted students reconstructed each of their drawings as arguments. The arguments were coded on the basis of Walton's (2006) argument pattern components of conclusion, premise, premise, and premise only if the arguments were scientifically correct. The students constructed arguments consisting of code combinations formed the categories. Additionally, frequency-percentage calculations were performed. The findings are shown in Table 3.

Table 3. Analysis of gifted students' arguments.

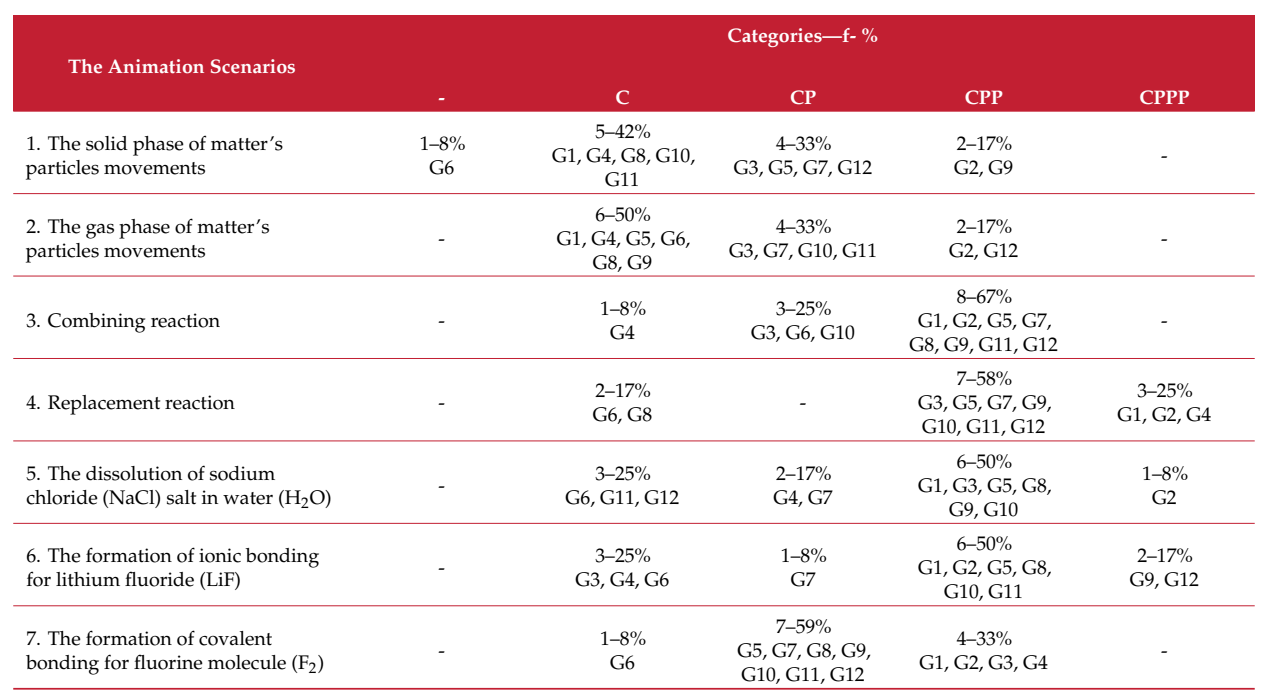

In Table 3, frequency is shown by $\mathrm{f}$, percentages by $\%$, conclusion code by $\mathrm{C}$, and premise code by $\mathrm{P}$. Additionally, the conclusion category is shown by $\mathrm{C}$, conclusion-premise category by $\mathrm{CP}$, conclusion-premise-premise category by $\mathrm{CPP}$, and conclusion-premise-premise-premise category by CPPP. For each of the categories, the students' arguments are shown by G, G for the shortening of "gifted student".

In Table 3, it can be seen that for the first animation scenario, $50 \%$ of the gifted students could justify their claims with at least one premise or more. For the second, third, fourth, fifth, sixth, and last animation scenarios, 50\%, 92\%, 83\%, 75\%, 75\%, and $92 \%$ of the gifted students could justify their claims with at least one premise or more, respectively. Therefore, the gifted students' arguments analysis showed that they could justify their claims with premises. Additionally, their argument construction success increased through the animation scenarios, which suggests 
their argumentation skills were improved too. For backing up the given findings, examples from gifted students' arguments are provided below.

1. The solid phase of matter's particles movements:

Gifted student coded by 2 (G2): When the temperature increases, the solid phase of matter's particles much more vibrate (conclusion). Therefore, the space among the particles increase (premise). On the other hand the particle sizes remain the same (premise).

2. The gas phase of matter's particles movements:

G12: Gas particles vibrate, move about, and slide past each other (conclusion). The space among the particles is too much (premise). The particles also collide flexibly with the walls of the container (premise).

3. Combining reaction:

G12: A new compound formed. For example, it could be calcium sulfur (conclusion). Two different atoms reacted. For example, calcium and sulfur reacted (and formed ionic bonding) (premise). A new particle was formed from the reactants (premise).

4. Replacement reaction:

G1: New particles were formed (conclusion). We pictured the stage of product forming (premise). The particles did flexible-collisions for reaction (premise). Additionally, proper geometry was needed for reactions to occur (premise).

5 . The dissolution of sodium chloride $(\mathrm{NaCl})$ salt in water $\left(\mathrm{H}_{2} \mathrm{O}\right)$ :

G9: Water particles hydrate the salt ions (conclusion). Each positive ions of salt were hydrated with six water particles and with each particle's oxygen side (premise). Each negative ions of salt were hydrated with six water particles and with each particle's hydrogen side (premise).

6. The formation of ionic bonding for lithium fluoride (LiF):

G5: The atoms did electron giving-taking (conclusion). Lithium atom gave an electron to fluorine atom (premise). Fluoride ion with negative charge formed (and lithium ion with positive charge formed and also ionic bonding between ions was formed) (premise).

7. The formation of covalent bonding for fluorine molecule $\left(\mathrm{F}_{2}\right)$ :

G11: After the formation of covalent bonding the bonding atom's last shell electrons were equal to eight (conclusion). The atoms shared their electrons for covalent bonding (premise). 


\section{Discussion}

In this study, gifted students were given the task to complete the missing parts of chemistry animation scenarios based on STEAM and then reconstruct them as an argument as an enrichment. At the end of the study, it was found that gifted students were able complete the missing parts of the chemistry animation scenarios in order to construct proper concept images. Then, they reconstructed their drawings as arguments; therefore, it could be said that their argumentation skills were enhanced based on their increasing success of arguing the missing parts of the chemistry animation scenarios with the help of justifying their conclusions with premises.

Nakhleh (1992) stated that some students are incapable of understanding chemistry because of its submicroscopic nature. In the first part of the study, the gifted students argued each missing part of the chemistry animation scenarios in small groups, and then they individually drew their images about the missing parts. The results show that they could produce scientifically proper concept images about the chemical concepts. Therefore, it could be said that "this argumentation practice based on STEAM" teaching environment could help gifted students to be able to understand chemistry concepts by arguing their submicroscopic nature. In the literature, it was stated that in argumentation-based teaching domains, students can understand the concepts much more properly, learn the nature of science, and be able to conduct an inquiry process (Kaya and Kılıç 2008). Therefore, in this study, by giving the chance to the gifted students to experience an argumentation process, they were able to understand the concepts properly by producing proper concept images.

According to Piro (2010), educating students in the science, technology, engineering, arts, and mathematics (STEAM) amalgamation learning environment helps them to gain better questioning skills in order to develop critical thinking skills. In this argumentation practice based on STEAM study, the gifted students were able to argue the missing parts of the animation scenarios in small groups, meaning they had the chance to criticize their own and others' thinking ways, which would probably help them to gain better argument construction skills in order to develop argumentation and critical thinking skills. According to the (Cambridge International AS \& A Level Thinking Skills 9694, Syllabus, Syllabus 2020-2022), when students are able to construct scientific arguments, they are able to think critically too, as the current study results show.

In the literature, Olszewski-Kubilius and Corwith (2018) proposed using challenging curriculums and also domain-specific performance indicators for the education of the gifted. Therefore, in this study, as a challenging program option, a two-step method, which consisted of, firstly, arguing the missing parts of the 
animation scenarios in small groups and then drawing the missing parts individually, and secondly, reconstructing the drawings as arguments, was utilized according to the literature. Additionally, being domain-specific performance indicators, the students' drawings and the students' arguments were used, as proposed in the literature. These two factors may have helped the gifted students to produce proper concept images and to construct scientific arguments.

On the other hand, gifted students' learning needs require "interrogating new knowledge", "thinking it through", and "linking and organizing" (Stott and Hobden 2016). This study employed an argumentation practice based on STEAM which gave the students the chance to think through new knowledge through small group discussions, interrogate new knowledge by drawing and producing proper concept images, and link and organize through argument construction.

Ziegler et al. (2012) stated that for the education of the gifted, holistic perspective and multidisciplinary approach are very important. The current study provided gifted students with a multidisciplinary approach based on the STEAM amalgamation, encouraging students to criticize their newly adopted knowledge with the help of the arts too. Then, a holistic perspective was also experienced by the gifted students by viewing the whole process as an argument.

This study was limited to researcher triangulation and data triangulation. For further research, different triangulations such as environmental triangulation or method triangulation could be offered too (Guion 2002). In Appendix A, a mini guide for educators of gifted students is provided for further studies for the replication of the current study. In addition to the above, different programming options and enrichment studies could be proposed in further research.

Funding: No funding was used.

Conflicts of Interest: The education of gifted, chemistry education, argumentation.

\section{Appendix A}

A Mini Guide for Educators of Gifted Students for Further Studies for the Replication of the Current Study

- Introduce "STEAM", "chemistry animation scenarios", "argumentation", and "argument" concepts to your students before the application process.

- Give the chemistry animation scenarios, each with a missing part, to your students for arguing. You can use the current study's chemistry animation 
scenarios, or you can construct your own according to the concepts you prefer to teach.

- Give time to your students to argue the chemistry scenarios' missing parts in small groups. The students could build the groups, or you can, whichever you think will result in high student attendance and performance.

- Make sure your students criticize their own and others' thinking strategies. They must construct arguments and counter-arguments in groups. Whenever it is necessary, you can prompt the group discussions with proper questions such as

- "Is there anyone who wants to justify your friend's argument?"

- "Is there anyone who wants to refute your friend's argument?"

- "I'm thinking as ... How could you justify or refute me?" ...

- Then, make your students complete the chemistry animation scenarios individually.

- $\quad$ At the end, make your students criticize the whole process by constructing arguments. You can use Walton's (2006) argument pattern, like this study, or you may choose a much more proper argument pattern according to your students' academic needs from the literature.

- Be sure to provide feedback for your students' drawings and arguments in the following lesson. You can use the codes and categories in the current study, or you can construct your own.

Conflicts of Interest: The author declares no conflict of interest.

\section{References}

Akyol, Hakime, and Ümmüye Nur Tüzün. 2020. Özel yetenekli öğrencilerin öğretim ortamlarının zenginleştirilmesi: Canlı heykel olarak Marie Curie ve kızı Irene. Bilim Armonisi 3: 53-59. [CrossRef]

Breiner, Jonathan M., Shelly Sheats Harkness, Carla C. Johnson, and Catherine M. Koehler. 2012. What is STEM? A discussion about conceptions of STEM in education and partnership. School Science and Mathematics 112: 3-14. [CrossRef]

Cambridge International AS \& A Level Thinking Skills 9694, Syllabus. 2020-2022. Available online: https://www.cambridgeinternational.org/Images/415052-2020-2022-syllabus.pdf (accessed on 19 July 2020).

Demircioglu, Hülya, and Selma Vural. 2016. Ortak bilgi yapılandırma modelinin (OBYM), sekizinci sınıf düzeyindeki üstün yetenekli öğrencilerin kimya dersine yönelik tutumları üzerine etkisi. Hasan Ali Yücel Ĕ̆itim Fakültesi Dergisi 13: 49-60. 
Demircioglu, Hülya, Selma Vural, and Gökhan Demircioğlu. 2012. 'React' stratejisine uygun hazırlanan materyalin üstün yetenekli öğrencilerin başarısı üzerine etkisi. Ondokuz Mayıs Üniversitesi Ĕ̆itim Fakültesi Dergisi 31: 101-44.

Demircioglu, Gökhan, Selma Vural, and Hülya Demircioğlu. 2014. Yapılandırmacı yaklaşımın üstün yetenekli öğrencilerin anlamaları üzerine etkisi: 'Erime-donma'. Dicle Üniversitesi Ziya Gökalp Ĕgitim Fakültesi Dergisi 22: 31-50.

Demircioglu, Gökhan, Hülya Demircioğlu, and Selma Vural. 2016. 5E öğretim modelinin üstün yetenekli öğrencilerin buharlaşma ve yoğuşma kavramlarını anlamaları üzerine etkisi. Kastamonu Ĕ̆itim Dergisi 24: 821-38.

Gonzalez, Heather B., and Jeffrey J. Kuenzi. 2012. Science, Technology, Engineering, and Mathematics Education: A Premier. Prepared for Members and Committees of Congress, August 1; Available online: https://digital.library.unt.edu/ark:/67531/metadc122233/m1/1/ high_res_d/R42642_2012Aug01.pdf (accessed on 19 July 2020).

Guion, Lisa A. 2002. Triangulation: Establishing the Validity of Qualitative Studies. Available online: https://sites.duke.edu/niou/files/2014/07/W13-Guion-2002-TriangulationEstablishing-the-Validity-of-Qualitative-Research.pdf (accessed on 17 May 2020).

Harut, Seçil B., Ümmüye N. Tüzün, and Gülseda Eyceyurt-Türk. 2019. Özel yetenekli öğrencilerin Prof. Dr. Fuat Sezgin'in kimya prototiplerini argümesi. Cumhuriyet Uluslararası Ĕ̆itim Dergisi 8: 1187-200.

Hofman-Bergholm, Maria. 2020. High Quality Educated Teachers and High-Quality Textbooks-The Two Pillars of Quality Education. Basel: Licensee MDPI, Available online: http: //creativecommons.org/licenses/by/4.0/ (accessed on 10 January 2021).

Kaya, Osman N., and Ziya Kılıç. 2008. Etkin bir fen öğretimi için tartışmacı söylev. Ahi Evran Üniver-sitesi Kırşehir Eğitim Fakültesi Dergisi 9: 89-100.

Kopnina, Helen. 2020. Transitioning to Quality Education: Examining Education for Sustainable Development Goals, Its Limitations, and Alternatives. Basel: Licensee MDPI, Available online: http://creativecommons.org/licenses/by/4.0/ (accessed on 10 January 2021).

Land, Michelle H. 2013. Full STEAM ahead: The benefits of integrating arts into STEM. Procedia Computer Science 20: 547-52. [CrossRef]

Nakhleh, Mary B. 1992. Why some students don't learn chemistry. Journal of Chemical Education 69: 191-96.

Olszewski-Kubilius, Paula, and Susan Corwith. 2018. Poverty, academic achievement, and giftedness: A literature review. Gifted Child Quarterly 62: 37-55. [CrossRef]

Osborne, Jonathan, Sibel Erduran, and Shirley Simon. 2004. Enhancing the quality of argumentation in school science. Journal of Research in Science Teaching 41: 994-1020. [CrossRef]

Piro, Joseph. 2010. Going from STEM to STEAM, Education Week. Available online: http://www.ischoolcampus.com/wp-content/uploads/2010/03/Going-FromSTEM-to-STEAM.pdf (accessed on 10 March 2010). 
Robelen, Erik W. 2011. STEAM: Experts Make Case for Adding Arts to STEM, Education Week. Available online: http://www.bmfenterprises.com/aep-arts/wp-content/uploads/2012/02/ Ed-Week-STEM-to-STEAM.pdf (accessed on 7 December 2011).

Rogers, Karen B. 2007. Lessons learned about educating the gifted and talented: A synthesis of the research on educational practice. Gifted Child Quarterly 51: 382-96. [CrossRef]

Sanders, Mark. 2009. STEM, STEM education, STEMmania. The Technology Teacher 68: 20-26. Stake, Robert E. 1995. The Art of Case Study Research. California: Sage Publications.

Stott, Angela, and Paul A. Hobden. 2016. Effective learning: A case study of the learning strategies used by a gifted achiever. Gifted Child Quarterly 60: 63-74. [CrossRef]

Subotnik, Rena F., Paula Olszewski-Kubilius, and Frank C. Worrell. 2011. Rethinking giftedness and gifted education: A proposed direction forward based on psychological science. Psychological Science 12: 3-54. [CrossRef]

Taber, Keith S. 2010. Challenging gifted learners: General principles for science educators; and exemplification in the context of chemistry education. Science International Education 21: $5-30$.

Tüysüz, Mustafa, and Ümmüye N. Tüzün. 2019. Özel yetenekli öğrenciler için adli kimya eğitimi. Başkent University Journal of Education 6: 213-24.

Tüzün, Ümmüye Nur, and Mustafa Tüysüz. 2019a. Kara kutu deneylerinin özel yetenekli öğrencilerin eleştirel düşünmelerine etkisi. Türkiye Kimya Derneği Dergisi 4: 81-94.

Tüzün, Ümmüye Nur, and Mustafa Tüysüz. 2019b. Mobil argümantasyon ile özel yetenekli bireylere adli bilimler öğretimi. Bilim Armonisi 2: 25-34. [CrossRef]

Tüzün, Ümmüye Nur, and Mustafa Tüysüz. 2019c. Özel yetenekli bireylerin öğretim ortamlarının zenginleştirilmesi-farklılaştırılmasında kimya-biyoloji-astronomi-toksikoloji-teknoloji-sanat-bilim felsefesi örneği. Bilim Armonisi 1: 9-18.

Umar, Çiğdem N. 2017. Üstün zekâlı ve yetenekli öğrencilere kimya öğretimi. Kimya Öğretimi. Edited by Alipaşa Ayas and Mustafa Sözbilir. Ankara: Pegem Akademi, pp. 751-70.

Walton, Douglas N. 2006. Fundamentals of Critical Argumentation. New York: Cambridge University Press.

West, Terry L. 1994. The Effect of Argumentation Instruction on Critical Thinking Skills. Doctoral dissertation, Southern Illinois University, Chicago, IL, USA.

Ziegler, Albert, Heidrum Stoeger, and Wilma Vialle. 2012. Giftedness and gifted education: The need for a paradigm change. Gifted Child Quarterly 56: 194-97. [CrossRef]

(C) 2021 by the author. Licensee MDPI, Basel, Switzerland. This article is an open access article distributed under the terms and conditions of the Creative Commons Attribution (CC BY) license (http://creativecommons.org/licenses/by/4.0/). 


\title{
Academic Literacy Supporting Sustainability for Mathematics Education-A Case: Collaborative Working as a Meaning Making for " $2 / 3$ "?
}

\author{
Päivi Perkkilä and Jorma Joutsenlahti
}

\section{Introduction}

Sustainable education is currently being developed, in many countries, in many areas of basic education, vocational education and training, polytechnics, and universities. Education for sustainable development (ESD) as a long-term learning process supports a better life in various areas, such as social, economic, and environmental. To support a good and sustainable learning culture in different fields of education, we should build sustainable development so that we can understand the constantly changing world and its challenges. In the field of mathematics education, this means that we must develop students' academic literacy in mathematics (ALM) and 21st Century competences so that students have creativity to solve and model ESD-based mathematical problems, namely in the social, economic, and environmental fields. These kinds of skills can support the lives of students in the present and future (Widiaty and Juandi 2019).

\subsection{Education for Sustainable Development}

Zehetmeier and Krainer (2011) have argued that sustainability mainly belongs to ecological and economical vocabulary, but is more and more employed in the educational realm too. Already in 1657, Comenius highlighted sustainability in educational in his book "Didactica Magna" (Flitner 1970), with a chapter about the "foundation of lasting teaching and learning". This "foundation of lasting teaching and learning" refers to the view of ESD. Fullan (2006) observed sustainability in the light of educational change as "the capacity of a system to engage in the complexities of continuous improvement with the deep values of human purpose". Fullan (2006) rests his definition about sustainability on Hargreaves and Hargreaves and Finks' (2003) viewpoint, that is "sustainability does not simply mean whether something will last. It addresses how particular initiatives can be developed without compromising the development of others in the surrounding environment now and in the future". 
All these definitions of sustainability are based on durable continuation. In the educational realm, we can understand this durable continuation as lifelong learning. Concerning education, good teaching and learning that matters lasts for life, and both are inherently sustaining processes. Supporting and maintaining such deep aspects of teaching and learning, which endure and foster sophisticated understanding and lifelong learning for all, builds the main core for sustainable development in education. In this respect, we want to uncover how the collaborative aspect (working in pairs) helps prospective class teachers with meaning making for the mathematical symbol "2/3". In 2019, we published an article about "What kind of meanings alone working prospective class teachers found for the mathematical symbol " $2 / 3$ "” (Joutsenlahti and Perkkilä 2019). In the abovementioned article, students worked alone and tried to find different meanings for the mathematical symbol " $2 / 3$ " and the subject of our study was the separate answers given by each student. In the research at hand, sustainability does not simply mean whether prospective class teachers' meaning making will last; we want to see if collaborative working enriches prospective class teachers' skills to produce their meaning making of the symbol "2/3" compared with the situation when they were working alone (cf. Fullan 2006; Hargreaves and Finks' 2003; Zehetmeier and Krainer 2011). In this sense, we can consider how pedagogical practices such as collaborative working methods support mathematical insights and mathematical thinking. Collaborative working methods, here meaning making collaboratively, are part of academic literacy, which is linked to ESD and $21^{\text {st }}$ Century competences (see Figure 1 ).

\subsection{Academic Literacy and 21st Century Competences}

In the present study, we have expanded the ALM framework to support sustainable development in mathematics education (see Figure 1). Especially we have new interpretations in the context of collaborative mathematical thinking and its impact on meaning making for the symbol " $2 / 3$ ". In this way, we want to see if the collaborative aspect reinforces and enriches the students' meaning making for the mathematical symbol " $2 / 3$ " and whether collaborative mathematical thinking could be robust enough for ALM skills and for the ESD. In Figure 1, we have described how ALM relates to ESD and to 21st Century competences. 


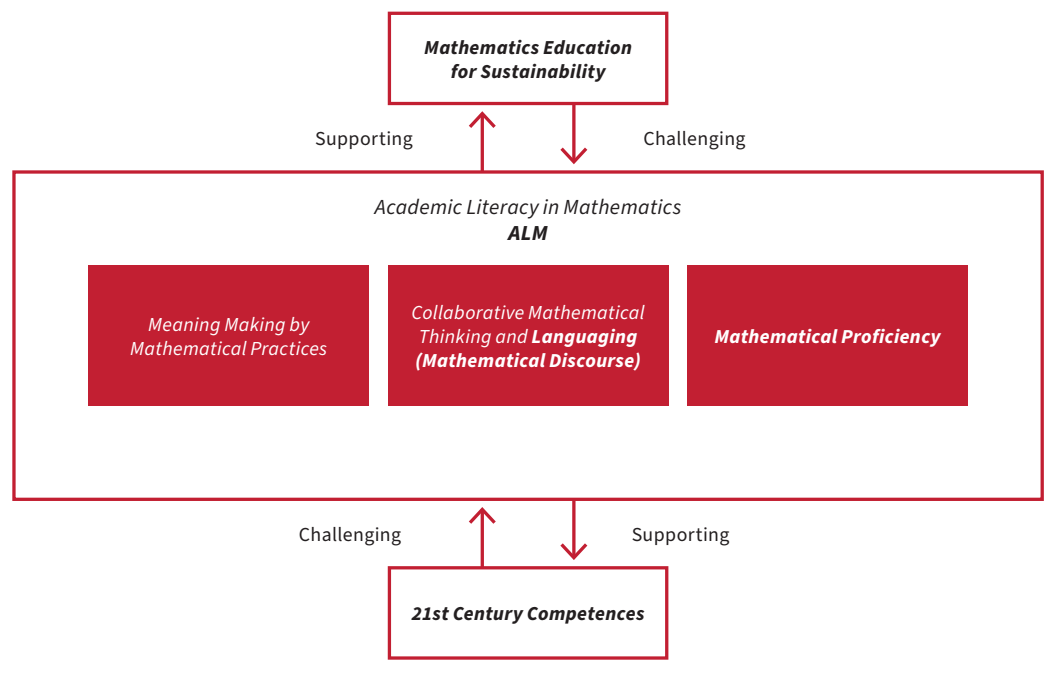

Figure 1. Linking Academic Literacy in Mathematics (ALM) to Education for Sustainable Development (ESD) and 21st Century Competences (adapting Moschkovich 2015a, 2015b, 2019; Widiaty and Juandi 2019).

On the one hand, in Figure 1, good skills in ALM support both ESD and 21st Century competences, but on the other hand, ESD and the mentioned competences challenge ALM skills. We see that good 21st Century competencies as future citizen skills support both the ALM and sustainable development perspectives in developing mathematics teaching and learning. These future citizen skills include the following areas: civic literacy, global awareness, and cross-cultural skills; critical and inventive thinking; communication, collaboration and information skills (Ministry of Education Singapore 2018; cf. Partnership for 21st Century Learning 2019; Valli et al. 2014). Previously mentioned competences are central abilities of thinking, working, and mastery of tools, and they are considered future competences that future citizens will need (see Valli et al. 2014). As far as ALM skills are concerned, these competences are recognizable in the subareas of ALM skills. However, both ESD and the 21st Century competences are broader than the skills of the ALM, so ESD and 21st Century competences are also challenging ALM skills.

Moschkovich (2015a, 2015b, 2019) uses the term academic literacy to refer to literacy in mathematics studies. Generally, the concept literacy has been interpreted and studied from many different perspectives and there are several related concepts, for example, technological literacy, information literacy, online literacy, image literacy, and visual literacy (Kupiainen et al. 2015). Multiliteracy has emerged 
as the overarching concept that combines the different perspectives. It should be remembered that this is a diverse area of competence, not only in reading but also in writing or production (Kupiainen et al. 2015). The concept "literacy" is based on the English term multiliteracy, which means that there are different textual practices in different social contexts; for example, these social contexts may be related to different disciplines such as mathematics (Kalantzis and Cope 2012). In this article, we illustrate the connection mainly between the ALM framework (see Moschkovich 2015a) and ESD. We also partly observe the meaning of ALM and ESD in the 21st Century competences viewpoint. ALM is understood here through three integrated components: mathematical proficiency, mathematical practices, and mathematical discourse (cf. Kilpatrick et al. 2001). We concentrate, especially, on two components of ALM: mathematical practices and mathematical discourse (languaging). Concerning sustainability in mathematics education, we see that good ALM skills in mathematics support Shulman's (1986) three categories of teacher's content knowledge: subject matter content knowledge, pedagogical content knowledge, and curricular knowledge. We must take these three areas into account if we want to develop teachers' and trainees' expertise in mathematics education and sustainable development in mathematics learning (Joutsenlahti and Perkkilä 2019).

Mathematics is seen as a gatekeeper in education: Good skills in ALM (see Shulman's (1986) three categories of teacher's content knowledge) ensure better chances of success in studies and, thus, a commitment to lifelong learning (Díez-Palomar et al. 2018). Joutsenlahti and Perkkilä (2019) have pointed out that if the mathematical content knowledge and pedagogical content knowledge were deepened in teacher education by making them a more sustainable basis through pedagogical arrangements (e.g., collaborative thinking), this will help to build a sustainable basis for future generations' mathematics education. Concerning pedagogical arrangements, ALM (Moschkovich and Zahner 2018) includes both sociocultural and discursive aspects of mathematical activity. These mean participation in mathematical practices and mathematical discourse. This view assumes that mathematical proficiency, mathematical practices, and mathematical discourse-the elements of ALM-work together and support collaborative mathematical thinking and languaging to build sustainable understanding in mathematics.

\section{The ALM Framework Supporting Sustainability in Mathematics Education}

The mission of the fourth goal of the Agenda for Sustainable Development of The United Nations (UN 2018) for 2030 is to secure inclusive and quality education for all and, in this way, promote lifelong learning. As mentioned before, mathematics 
learning acts like a gatekeeper in education: those who succeed in mathematics education and have better scores in mathematics will end comprehensive school with better educational trajectories than those who underachieve in this subject (Díez-Palomar et al. 2018). To develop sustainable mathematics education, teachers' mathematical knowledge and skills for building innovative learning situations act like a gatekeeper concerning pupils' development in creating sustainable and meaningful understanding about school mathematics. In this sense, it is important to explore prospective class teachers' conceptual interpretations and, as a case example, their interpretations for the mathematical symbol " $2 / 3$ ", especially in collaborative situations, from the perspective of sociocultural situations of ALM.

\subsection{The Components of ALM}

Widiaty and Juandi (2019) treated, in their article, education for sustainable development (ESD) from the mathematics education point of view. They interpreted mathematics as a tool for understanding, analyzing, and solving problems in the neighborhood and surrounding society. To understand the aspect of sustainable development in mathematics, we need to develop the skills and creativity of teachers to plan for the problems of the surrounding society. To guide pupils to apply mathematics in the spirit of ESD, teachers need to have a good conceptual understanding of mathematics. Through conceptual understanding, they will promote sustainability in their own mathematical thinking and professional development in mathematics. Teacher education has great responsibility because conceptual understanding should be strengthened during teacher education by paying attention to the importance of ALM and reinforcing ESD thinking with ALM and 21st Century competences. As mentioned before, Moschkovich (2015a, 2015b, 2019) has defined ALM as three integrated aspects: mathematical proficiency, mathematical practices, and mathematical discourse (cf. Kilpatrick et al. 2001). In the following figure (Figure 2), we present the ALM components from the perspective of this study. 


\begin{tabular}{|c|c|c|c|}
\hline & Mathematical Proficiency & Mathematical Practices & $\begin{array}{c}\text { Languaging } \\
\text { (cf. Mathematical Discourse) }\end{array}$ \\
\hline $\begin{array}{l}1 . \\
2 . \\
3 . \\
4 . \\
5 .\end{array}$ & $\begin{array}{l}\text { Conceptual understanding } \\
\text { Procedural fluency } \\
\text { Strategic competence } \\
\text { Adaptive reasoning } \\
\text { Productive disposition }\end{array}$ & $\begin{array}{l}\text { 1. Meaning making } \\
\text { 2. Perseverance } \\
\text { 3. Abstract reasoning } \\
\text { 4. Justification of the solution } \\
\text { 5. Constructive criticism } \\
\text { 6. Model with mathematics } \\
\text { 7. Appropriate tools } \\
\text { 8. Precision } \\
\text { 9. Structures } \\
\text { 10. Regularities }\end{array}$ & $\begin{array}{l}\text { 1. Languaging } \\
\text { - Natural language (oral or } \\
\text { written) (NL) } \\
\text { - Mathematical symbolic } \\
\text { language (MSL) } \\
\text { - Pictorial language (PL) } \\
\text { - Tactile functional language } \\
\text { (TFL) } \\
\text { 2. Collaborative Thinking }\end{array}$ \\
\hline
\end{tabular}

Figure 2. The modified components of ALM of this study (adapting Joutsenlahti and Kulju 2016; Kilpatrick et al. 2001; Moschkovich 2015a, 2015b).

In this article, we will focus especially on the sociocultural aspects (see the mathematical practices and languaging in Figure 2) of the ALM framework in the context of prospective class teachers' mathematics education. These sociocultural aspects include participation in mathematical practices and participation in mathematical discourse. Mathematical proficiency includes the traditional cognitive aspects of mathematical activity such as mathematical reasoning, thinking, conceptual development, and metacognition (Kilpatrick et al. 2001; Moschkovich 2019; Moschkovich and Zahner 2018). We agree with Moschkovich (2019) and Moschkovich and Zahner (2018) that the sociocultural aspects of the ALM framework will not be separated from mathematical proficiency. The sociocultural aspects more likely assume that all the fields of ALM work together. When these three aspects are socioculturally included in mathematics learning, it will make the learning situations dynamic and will improve the meaning making of conceptual understanding in mathematics. These situations involve multiple modes of languaging like oral and written texts, gestures, drawings, objects, tables, graphs, symbols, etc. We need to account for all three ALM categories that develop mathematics teaching toward greater sustainability in mathematical meaning making and in achieving better learning results. Our focus is on education for sustainable development in prospective class teachers' mathematics education because as in-service teachers, they will act as key roles in building the quality of mathematics education for all and promoting sustainable meaningful learning in mathematics education. Next, we will clarify the components of ALM in this study.

\subsubsection{Mathematical Proficiency}

Moschkovich (2015b) stated that the mathematical competence model published in 2001 (Kilpatrick et al. 2001) is still valid for describing the cognitive domain of 
academic literacy. This model by Kilpatrick et al. (2001) presents mathematical proficiency, consisting of five features: conceptual understanding, procedural fluency, strategic competence, adaptive reasoning, and productive disposition (see also Joutsenlahti 2005).

The feature of conceptual understanding includes an understanding about mathematical concepts and relationships between them, as well as mathematical operations and their relationship to mathematical concepts (Joutsenlahti 2005; Kilpatrick et al. 2001). Conceptual understanding is reflected in the meanings that the mathematical problem solver gives to the solution (What does the result mean for the assignment?), the solution process (Why do the selected procedures and methods work in this solution?), and the final question (Why is the answer correct for this problem?) (Moschkovich 2015b). Procedural fluency is demonstrated by the ability to use mathematical procedures flexibly, carefully, efficiently, and expediently (Joutsenlahti 2005; Kilpatrick et al. 2001). In schools, the role of mechanical computing is particularly emphasized, but computational competence is often an essential part of conceptual understanding, and vice versa (Moschkovich 2015b). Strategic competence is the ability to formulate, present, and solve non-routine mathematical problems. The feature described above is central to problem solving. Adaptive reasoning is logical thinking, reflection, finding explanations, and witnessing. The last mentioned aspect of mathematical competence, productive disposition (the view of mathematics), reflects the learner's perception of the importance and usefulness of mathematics, as well as his or her own diligence and effectiveness in mathematics study (Joutsenlahti 2005; Kilpatrick et al. 2001). The five characteristics of mathematical proficiency (Figure 2) are in fact the cognitive component of academic literacy (Joutsenlahti and Kulju 2016). We can see that the cognitive component of academic literacy works like a tool which supports ESD and gives tools to formulate, present, model, and solve, for example, non-routine problems in the neighborhood and surrounding society. It is also connected to the meanings of 21st Century competences. This means that students should not only have the skills to think mathematically but they should have sensitivity to the problems found in the surrounding society, especially in the social, economic, and environmental fields (Widiaty and Juandi 2019); this is a real challenge for sustainable mathematics education.

\subsubsection{Meaning Making by Mathematical Practices}

In the United States, the Common Core State Standards (2019) define eight mathematical practices (see Figure 2) that can be interpreted in teaching mathematics from preschool to high school. The practices described guide students starting and 
mastering mathematical problem-solving processes. The mathematical practices are (the Common Core State Standards 2019): make sense of the problems and persevere in solving them, reason abstractly and quantitatively, construct viable arguments and critique the reasoning of others, model with mathematics, use appropriate tools strategically, attend to precision, look for and make of use structure, and look for and express regularity in repeated reasoning.

The first goal is to understand a given problem, whereby a mathematically proficient student begins problem-solving by first explaining to themselves the relevant features of the problem. The student uses typical problem-solving methods (for example, analogue problems, and trying special cases and simpler forms of the original problem in order to gain insight into the solution) in a consistent and persevering manner while monitoring and evaluating his/her own solution process. Secondly, the student must draw abstract and quantitative conclusions from the problem assignment. A mathematically proficient student understands the significance of the numbers or variables given in the problem assignment and their relationship to the problem assignment. He/she can contextualize the problem in such a way that he/ she is able to describe mathematical symbols in the problem and the relationships between them, as well as to simplify expressions and solve equations (the Common Core State Standards 2019; Moschkovich 2015b). Meaning making by mathematical practices includes several important competences, which researchers have related to sustainable development: 1. problem solving, critical thinking (e.g., construct viable arguments and critique the reasoning of others), action competence, and system thinking (e.g., model with mathematics, use appropriate tools strategically, attend to precision); 2. imagination, critical thinking and reflection, system of thinking, partnership, learning to work together, and participation in decision-making (e.g., meaning making, perseverance, constructive criticism); 3. systems thinking-the ability to see the interconnections between different dimensions and the complexity of systems and situations (e.g., abstract reasoning, precision, structures). The previously mentioned competences related to Sustainable Development are those skills which strengthen facing and solving mathematical problems, namely in the social, economic, and environmental fields, to support better life in the present and future (cf. Widiaty and Juandi 2019).

\subsubsection{Languaging and Collaborative Mathematical Thinking}

Moschkovich (2015a, 2015b) highlights mathematical discourse as the third component of ALM. She emphasizes that mathematical discourse is a broader concept than the language used to study mathematics. Moschkovich (2015b) defines 
mathematical discourse more precisely as communication competence that enables participation in mathematical practices. According to her, mathematical discourse includes not only oral and written texts, but also many modes (or symbol systems) such as gestures, activity materials, drawings, tables, graphs, and mathematical symbols. Interaction involves various registers such as school mathematics and home language. Moschkovich (2015b) emphasizes that in defining mathematical discourse, confrontation between the use of formal mathematics, such as the textbook definitions of concepts, and the student's own everyday register should be avoided. However, when looking at academic literacy and its components, we have chosen the third component as the "expression of mathematical languaging", instead of the student studying mathematics and discourse. In other words, the features of mathematical competence describe the cognitive potential of said learner, and the adoption of the mathematical practices given to the learner describes mathematical activity in the study and decision processes. The expression of mathematical languaging controls the abovementioned activity. It is based on the pupil's mathematical thinking, which is built on existing knowledge and skills (see Joutsenlahti 2005). This construction of thinking is also accompanied by the expression of thinking, where the student expresses his or her thinking in typical manners for mathematics by utilizing languages in a versatile way (e.g., Joutsenlahti and Rättyä 2015). Mathematical activity is also guided by collaborative working with other students and this interaction can generate mathematical knowledge and understanding. From the literacy point of view, the student expresses his or her mathematical thinking through natural language, mathematical symbolic language, pictorial language, and/or tactile functional language (Joutsenlahti and Kulju 2016; Joutsenlahti and Rättyä 2015). Likewise, mathematical thinking can be expressed using different symbolic systems (or languages) in different texts, for example, in verbal assignments, narratives, or in the oral presentation of a lesson (Joutsenlahti and Kulju 2017). By collaborative mathematical thinking, we mean here common work in pairs, where students share their ideas with each other (the other pair member) and produce joint solutions. In Figure 3, we clarify languaging as mathematical thinking. As mentioned before, languaging is divided in to four different parts. 


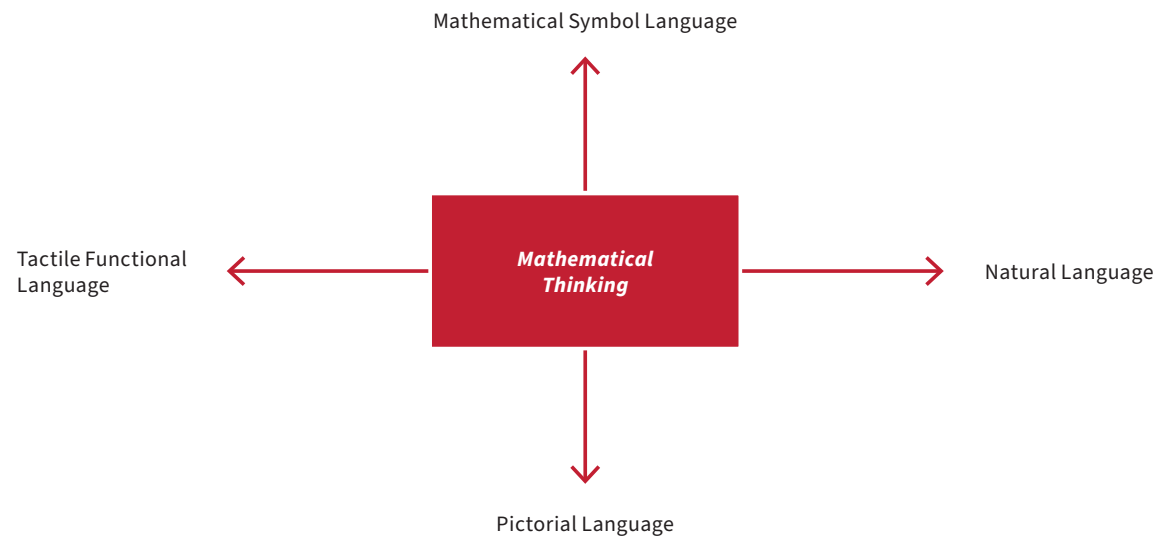

Figure 3. Languaging as multimodality in expressing mathematical thinking (adapting Joutsenlahti and Perkkilä 2019; Joutsenlahti and Rättyä 2015).

We call the process in which, for example, a pupil expresses his/her thinking as "languaging". We describe languaging in mathematics as referring to expressing one's mathematical thinking by different modes, either orally (by natural language) or in writing (by natural language, mathematical symbolic language, or pictorial language) (Joutsenlahti and Kulju 2017). In learning situations, especially with elementary school students, a tactile, functional language (working with manipulatives) is also involved as a fourth language, referring to expressing one's mathematical thinking. In mathematics textbooks, we can recognize three languages, which mathematics textbooks use as meaning making tools for mathematical concepts and procedures. Languaging of mathematical thinking helps pupils to structure their thinking and, in that way, understand mathematical concepts and procedures (Joutsenlahti and Perkkilä 2019; Kilpatrick et al. 2001; Moschkovich 2015b).

Collaborative learning aims at a relatively lasting change in a student's knowledge, collaboration, thinking, and attitudes. Collaborative thinking in groups/pairs facilitates verbal inference, explanation, evaluation, and reflection on what the individual knows. Through a shared reflection process, knowledge becomes meaningful and integrates into meaning structures (Hellström et al. 2015). In our study, collaborative mathematical thinking was manifested in pair work, where students must express their thinking to each other by languaging the meanings of the mathematical symbol " $2 / 3$ ". 


\section{Case: What Kind of Meanings Do the Prospective Class Teachers Find for the Mathematical Symbol "2/3"?}

We have chosen the concept of fractions and the symbol "a/b" as a case from school mathematics. Fractions are one of the most challenging areas in school mathematics (e.g., Martin et al. 2008; Morgan 2001; Perkkilä 2001; Vosniadou 1999). Pupils have trouble with fractions, especially understanding fractions as numbers that extend the whole number system to rational numbers (e.g., Joutsenlahti and Kulju 2017; Siegler et al. 2013). One must have a clear picture of the different meanings of fractions to understand this extension. The different meanings of fractions are introduced separately without clear context in the Finnish mathematics textbooks, in which the fractions are often taught emphasizing a procedural perspective. The conceptual understanding about fractions and their different meanings is left with less attention (cf. Lemke 2002).

\subsection{Literature Review of Meanings of the Symbol " $a / b$ "}

Researchers have found different subconstructs which are related to the symbol " $a / b$ ". Each subconstruct creates a context for the fraction that gives it a contextual meaning and these subconstructs also refer to the extension of whole numbers to rational numbers. Pantziara and Philippou (2012), for example, highlighted that the diverse constructs of fractions make it difficult for pupils understanding the concept of fractions. They described the following five subconstructs: part-whole, ratio, quotient, measure, and operator. We collected, from the literature, some typical approaches to the mathematical symbol " $\mathrm{a} / \mathrm{b}$ " in Table 1.

Table 1. The approaches and the meanings of the symbol " $\mathrm{a} / \mathrm{b}$ ".

\begin{tabular}{|c|c|c|c|c|c|}
\hline Approach to " $\mathrm{a} / \mathrm{b}$ " & Fraction & $\begin{array}{l}\text { Rational } \\
\text { number }\end{array}$ & Division & Ratio & Others \\
\hline $\begin{array}{c}\text { Mathematical and historical } \\
\text { approach (Klein 1968; Park et al. } \\
\text { 2013) }\end{array}$ & $\begin{array}{l}\text { part-whole, } \\
\text { set-theoretical }\end{array}$ & measurement & division & ratio & \\
\hline $\begin{array}{c}\text { Pedagogical approach A (Kieren } \\
\text { 1976; Stewart 2005; Pantziara } \\
\text { and Philippou 2012) }\end{array}$ & $\begin{array}{l}\text { part-whole, } \\
\text { set-operator }\end{array}$ & measurement & quotient & ratio & \\
\hline $\begin{array}{c}\text { Pedagogical approach } \\
\text { B.(Joutsenlahti et al. 2017) }\end{array}$ & $\begin{array}{l}\text { part out of a sum of } \\
\text { parts, a fraction of } \\
\text { given whole }\end{array}$ & $\begin{array}{l}\text { rational } \\
\text { number }\end{array}$ & division & ratio & probability \\
\hline
\end{tabular}

In Table 1, we separate two different approaches: (1) mathematical and historical and (2) pedagogical. The first one is based on how the symbol " $a / b$ " has been described and used from the point of view of mathematics and takes into account the 
historical development of the meanings of fractions. The pedagogical approach is based on analysis of the concept "fraction" in school mathematics and, especially, how it appears in mathematics textbooks. The more detailed description of the meanings of the symbol " $\mathrm{a} / \mathrm{b}$ " can be found in the writers' earlier article (Joutsenlahti and Perkkilä 2019).

The meanings of the concept could be presented in many different ways: mathematical symbolic language (e.g., "2/3"), natural language (e.g., "two of three parts"), or pictorial language (e.g., Figure 3) (Joutsenlahti and Perkkilä 2019; Shaughnessy 2005). Student's own meaning making processes need the use of natural language (most often, the student's mother tongue) and visual representations in learning activities (e.g., in studying new mathematical concepts and doing exercises) (Joutsenlahti and Perkkilä 2019; Lemke 2002; Morgan 2001).

If we want to learn mathematical concepts by understanding, we must have an awareness of how the new concepts are related to other concepts, and the ability to use them meaningfully in new contexts. We can distinguish the following expressions when we see mathematical symbolic language, mathematics by natural language, or by pictorial language: (1) from the point of view of a concept, we can speak of representations of the concept (Díez-Palomar et al. 2018; Joutsenlahti and Perkkilä 2019; Vosniadou 1999); (2) when a student expresses mathematical thinking, the student can use different multimodal approaches; and (3) when a reader makes meanings for a mathematical text, the languages can be seen as a multisemiotic approach (Joutsenlahti and Perkkilä 2019). In this article, we concentrate on connecting mathematical symbolic language and pictorial language by interpreting students' expressions in natural language.

\subsection{Research Questions}

In this article, we study the same phenomena related to the concepts (see Table 1) fraction, rational number, ratio, division, and probability as we did in our earlier article (Joutsenlahti and Perkkilä 2019). Now we have new data, which have been collected by a different study design: the prospective teachers (class teachers) answered the research questions in small groups (mainly two students in a group). We think that it is interesting to research how collaborative work helps students find meanings for the mathematical symbol " $2 / 3$ " in different given contexts. If we consider prospective class teachers, we can understand the difficulties in the conceptual learning of fractions and find new development targets for teacher education. The modified components of ALM (Figure 2) give us the useful theoretical frame, because they take into account the features of mathematical proficiency and practices. The third 
component of ALM is central from the point view of the interpretations and what kind of meanings the students found for the symbol " $2 / 3$ ".

In this article, the focus was to compare the answers given, by a single person (one student in a group) and in pairs (two students in a group), to the questions (Joutsenlahti and Perkkilä 2019):

1. What meanings do students give spontaneously for the symbol " $2 / 3$ "?

2. What relationships do students find for the given pictures and the symbol " $2 / 3$ "?

3. What kind of influence does the multisemiotic approach have on students' interpretations in collaborative thinking?

\subsection{Materials and Methods}

Our data were collected in two phases: in 2017, first-year students $\left(\mathrm{N}_{2017}=102\right)$ completed the research in single-person groups and in 2018, first-year students $\left(\mathrm{N}_{2018}=136\right)$ completed the research in two-person groups. The students were from the University of Tampere and the University of Jyväskylä. The data were collected during the mathematics didactics course for first-year students by questionnaires in spring 2017 and in spring 2018. In 2017, the questionnaire had two pages: on the first page students gave their opinions spontaneously about what different meanings the mathematical symbol " $2 / 3$ " can have and on the second page the students were asked to describe in natural language (Finnish) how the pictures A-D (Figure 4) were connected with the mathematical symbol " $2 / 3$ ". In 2018 , the questionnaire was answered in the computer environment, but the questions were mostly the same (there were some more questions). The idea of the questionnaire was based on our theoretical background (see Table 1). In both controlled tests, the students had the same time $(1 \mathrm{~h})$ to give answers. From the answers to the questionnaire, we wanted to obtain an understanding about students' perceptions of the meanings of the mathematical symbol " $2 / 3$ ", and, on the other hand, how a multisemiotic approach supports the interpretations of collaborative thinking.

The data were analyzed by mixed methods. We used the IBM SPSS statistics 24 program for typical statistical analysis (e.g., mean and standard deviation). The qualitative analysis was done by theory-guided content analysis (e.g., categorizations). We used the classification into the six categories presented earlier in the theoretical part of the article and, on the other hand, the categories generated by the answers. 


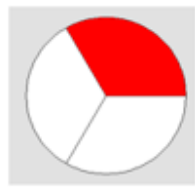

A

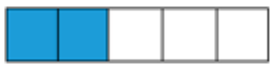

B
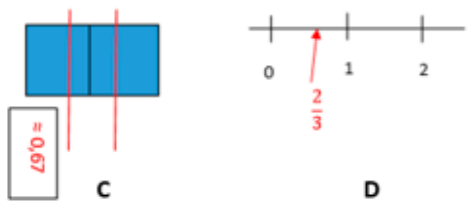

D

Figure 4. The second question of the research questionnaire: How the figures A-D describe mathematical symbol "2/3" (Joutsenlahti and Perkkilä 2019).

\section{Results}

In the first question of the questionnaire, the first-year students (N2017 = 102 and N2018 = 136) gave as many meanings as they discovered for the mathematical symbol " $2 / 3$ ". If we study the results from the point of view of groups, we can see that, in 2017, there were 102 students who worked alone (single/one student per group) and, in 2018, there were 68 groups (two students per group). Student groups spontaneously found different numbers of meanings for the symbol " $2 / 3$ ". The proportional quantities of the frequencies for each number (one, two, ..., five) are shown in Figure 5. We can see that working in pairs produced relatively more different meanings.

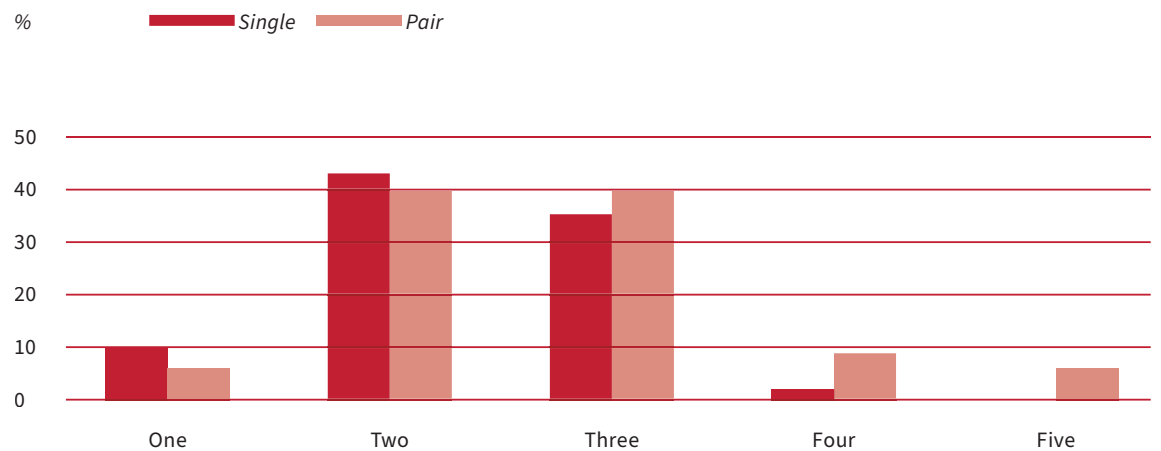

Figure 5. The proportional quantity of different meanings per a group that found single-student groups (single) and two-student groups (pair).

In the first question of the questionnaire, groups' (N2017 = 102 and N2018 = 68) spontaneous understanding about the mathematical symbol " $2 / 3$ " was, in most cases, as a fraction (N2017 = 77 and N2018 $=62$ groups gave "two thirds of a given whole" 
(Frac1) and $\mathrm{N}_{2017}=43$ and $\mathrm{N}_{2018}=36$ groups gave "two of three parts" (Frac2)), which are typical also in the Finnish mathematics textbooks. Ratio, rational numbers, and probability were mentioned the least.

In Figure 6, we can see that two-student groups found relatively more meanings "Division", "two thirds of a given whole" (Frac1), "two of three parts" (Frac2), and rational number (RatNum), but less meanings for probability (Prob) and ratio.

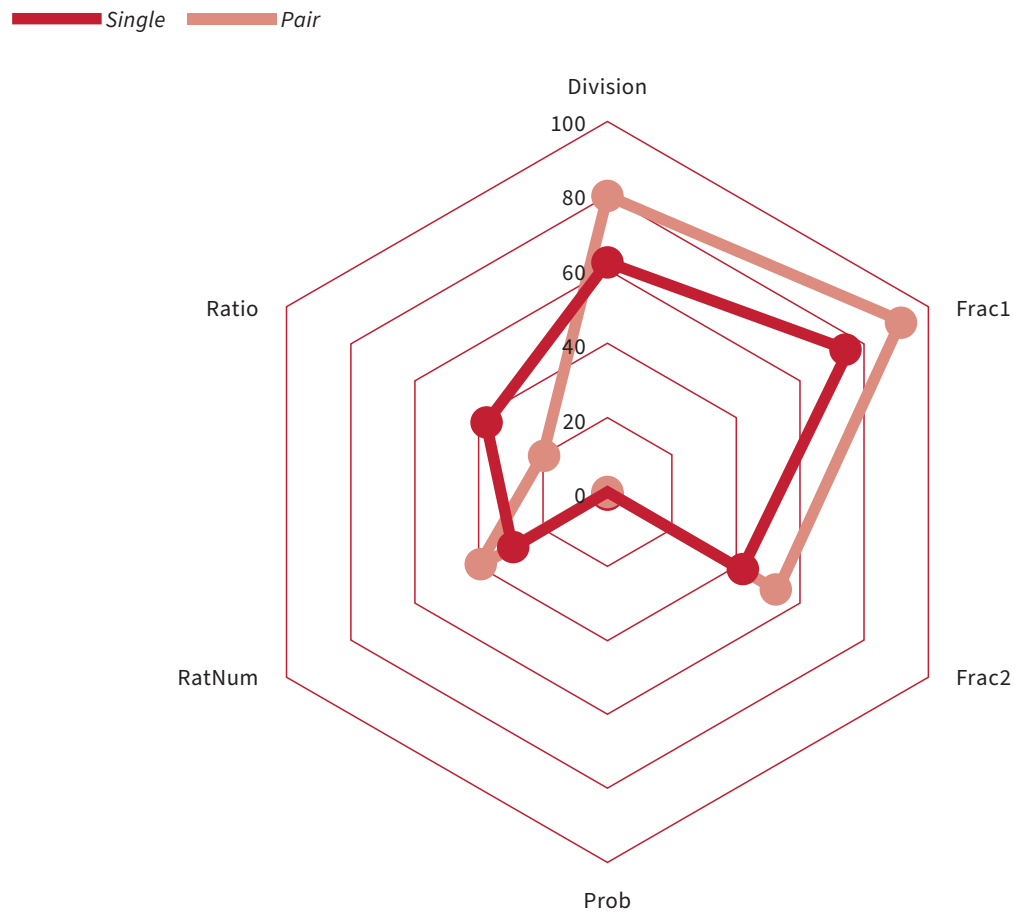

Figure 6. Proportional quantity (percent) of different meanings per a group (Single-single-student groups $\left(\mathrm{N}_{2017}=102\right)$; Pair-two-student groups $\left(\mathrm{N}_{2018}\right.$ = 68); Frac1-"two thirds of a given whole"; Frac2- "two of three parts"; Prob-probability; RatNum—rational number).

In the second question of the questionnaire, the groups' problem was writing how four figures (Figure 4) described the symbol "2/3". In Table 2, proportional frequencies (percent) are calculated as the observed frequencies for each group (single or pair). From the table, we can see that the groups' interpretations are mostly the same (highlighted with yellow), but the two-student groups have interpretations focused more on typical meanings (fraction in Figure A, division in Figure $\mathrm{C}$, and rational 
number in Figure D). Figure B (Table 2) is an exception because single-student groups found relatively more ratio meanings. "Other" meanings (Table 2) are meanings other than what have been given in the table. Most of these "other" meanings were vague descriptions that could not be meaningfully interpreted in this study. On the other hand, it is interesting to notice that two-student groups found, concerning Figure B, several different meaningful meanings. For example, the interpretation of the connection between Figure B and Frac1: "The figure has one whole, or three white squares, next to each other. Next to it is two-thirds of it, or two blue squares" (Two-student group 13). Collaborative thinking seems to be creative.

Table 2. Proportional frequencies (quantity per each group) of the interpretations how mathematical symbol " $2 / 3$ " is connected to figures A-D (Figure 3). (S-single-student groups $\left(\mathrm{N}_{2017}=102\right)$; $\mathrm{P}$-two-student groups $\left(\mathrm{N}_{2018}=\right.$ 68); Frac1- "two thirds of a given whole"; Frac2-"two of three parts"; Prob—probability; RatNum—rational number).

\begin{tabular}{lcccccccc} 
& \multicolumn{2}{c}{ Figure A } & \multicolumn{2}{c}{ Figure B } & \multicolumn{2}{c}{ Figure C } & \multicolumn{2}{c}{ Figure D } \\
\hline Meaning & $\mathbf{S ( \% )}$ & $\mathbf{P ( \% )}$ & $\mathbf{S ( \% )}$ & $\mathbf{P ( \% )}$ & $\mathbf{S ( \% )}$ & $\mathbf{P ( \% )}$ & $\mathbf{S ( \% )}$ & $\mathbf{P ( \% )}$ \\
\hline Frac1 & 57.8 & 69.1 & 0 & 4.4 & 17.6 & 4.4 & 44.1 & 29.4 \\
Frac2 & 37.3 & 30.9 & 0 & 1.5 & 0 & 0 & 0 & 0 \\
Ratio & 2 & 0 & 42.2 & 35.3 & 0 & 0 & 0 & 0 \\
Division & 1 & 0 & 1 & 0 & 54.9 & 66.2 & 1 & 1.5 \\
Rational & 2.9 & 0 & 0 & 2.9 & 1 & 0 & 40.2 & 64.7 \\
Other & 15.7 & 0 & 48 & 55.9 & 14.7 & 29.4 & 7.8 & 4.4 \\
\hline
\end{tabular}

Two-student groups $\left(\mathrm{N}_{2018}=68\right)$ had a new problem where they had to consider if the given Figure A or B (see Figure 3) could somehow describe the symbol "2/3" and if they answered in the affirmative, they gave an example about the meaning. In Table 3, we can see that the groups invented, by collaborative thinking, mostly good argumentations for Figures A and B, but, particularly, the meanings "two of three parts" (Frac2) and division were difficult to connect meaningfully to Figure B. Some of the argumentations for Figure B (e.g., Frac1 and division) show creative thinking, probably supported by collaborative thinking in the groups. The students invented new contexts guided by the Figures and they unequivocally adapted the content of the chosen concept to themselves. 
Table 3. Two-student groups' $\left(\mathrm{N}_{2018}=68\right)$ problem: Is it possible connect the given figure (A or B in Figure 3) to the symbol "2/3"? If the answer is "yes", then explain how. (N("yes"): frequency of "yes" answers, $N($ "good"): frequency of "good" answers).

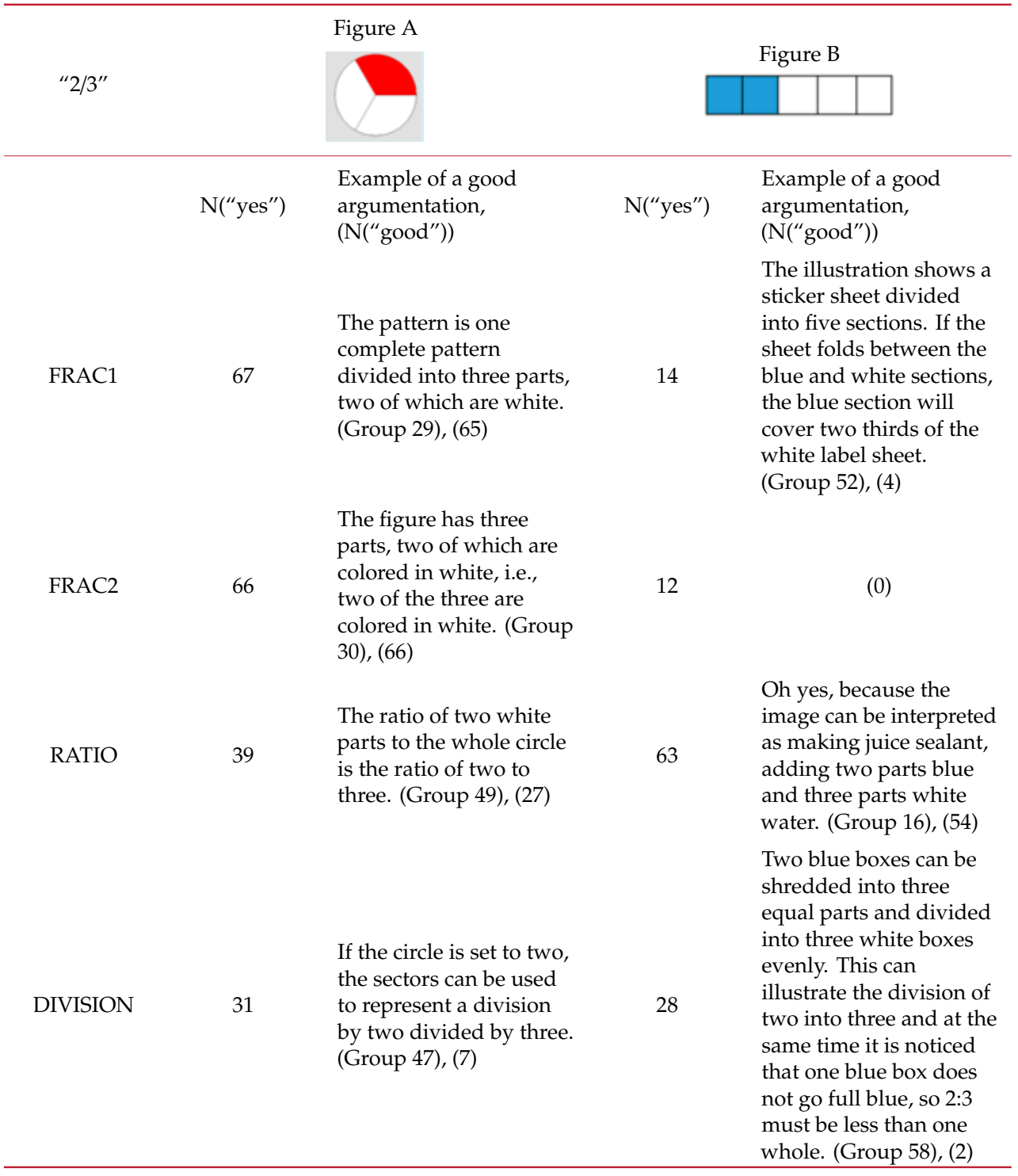




\section{Discussion}

\subsection{Collaborative Aspect}

The students interpreted the symbol " $2 / 3$ " most frequently as a fraction or division (Figure 6). The two-student groups (pair) found, spontaneously, a proportionally bigger quantity of different meanings (Figure 5) and mainly gave, proportionally, more different meanings (Figure 6) than the single-student groups. Collaborative thinking and discussions with the peer (languaging) in two-student groups obviously strengthened the student's conceptual understanding and strategic competence, which they needed in the problem-solving situation.

Figures A-D (Figure 4) were interpreted typically, with Figure A meaning fraction (Frac1 and Frac2), Figure B meaning ratio, Figure C meaning division, and Figure D meaning rational number (RatNum) or fraction (Frac1) (Table 2). The two-student groups found proportionally more of those typical meanings for the figures (especially A, C, and D), but Figure B was an exception (Table 2). In the interpretations of the meanings of Figures A-D, we noticed that the students connected three different languages (Figure 3): pictorial and mathematical symbolic languages were present and in the students' task to combine the meaning they found the two languages and expressed them by natural language. Collaborative thinking and peer discussion helped solve the problem of how the three languages are connected by the given information. Students need meaning making, justification skills, modeling with mathematics, structure understanding, and skills to find regularities during the solution process (mathematical practices in ALM).

The two-student groups thought systemically that the given figures A or B could somehow be interpreted as symbol " $2 / 3$ ". Table 3 shows that the groups found a lot of possible contexts for almost every option. Collaborative thinking in each group brought good examples for the typical connections (compare Table 2). It is interesting that the students invented contexts of new kinds for the familiar meanings of symbol " $2 / 3$ " by oral languaging, in which they reached a shared view. At the same time, when students create their own contexts for the different meanings of the symbol " $2 / 3$ ", they deepen their own and their mutual understanding about the concept and concept network.

Contradictions the students faced in the problems (e.g., Table 2) illustrated the narrowness of the learning materials, which were mainly constructed as definition-based, without an inquiry approach to concepts. These exercises help students understand that, e.g., the meanings of mathematical symbols are constructed only in their contexts. The curriculum (2014) emphasizes wide-ranging entities as 
part of sustainable development, which requires multiliteracy skills (e.g., languaging skills). Therefore, the learning materials should also include a variety of contexts for concepts (including symbols) and guide students to recognize different meanings. Working as described above enables students to deepen the concepts they have already learned as well as to acquire new concepts and integrate them into existing conceptual networks.

In general, the results show that collaborative mathematical thinking in pairs helped students find more meaning for the mathematical symbol " $2 / 3$ " (cf. Moschkovich 2015a, 2015b, 2019). Students took part in a math discussion that gave them good tips on the meaning of the discussion and how to share their thinking in mathematics learning situations (cf. Joutsenlahti and Kulju 2016). By considering the meaning of the mathematical symbol " $2 / 3$ " together, they also deepened their understanding about the meanings of the fraction (cf. Joutsenlahti and Perkkilä 2019).

\subsection{ALM Supporting Sustainability}

Re-examining our research from a languaging point of view in the data collection situation, we noted that when the students were answering our questionnaire they were codeswitching between pictorial, natural language, and mathematical symbolic language. At the same time, they explained their mathematical thinking to each other. There was a relationship between language and mathematical thinking in this situation. We can image that by solving the problems of our questionnaire, students had to have literacy in understanding pictorial language and understanding about mathematical language. Solving these problems together, students had to have proficiency in the content of mathematics but also competences in collaborative mathematical thinking and languaging, and mathematical practices. (cf. Moschkovich 2019; see also Figures 1 and 2). We can cautiously think that the ALM components were present in the research situation, helping students to deepen their mathematical thinking (see Figures 1 and 2). Students took part in mathematical discussions that gave them experiences on the meaning of discussion about sharing their thinking in mathematics learning situations (see Figures 1 and 2; collaborative mathematical thinking and languaging; mathematical practices). By considering the meaning of the mathematical symbol " $2 / 3$ " together, they also deepened their understanding of the meanings of the fraction (see Figures 1 and 2; mathematical proficiency). Moschkovich (2019) and Moschkovich and Zahner (2018) highlighted that sociocultural aspects of the ALM framework work together with mathematical proficiency. We can assume that these aspects were socioculturally 
included in our data gathering situations and made the learning situations dynamic and possibly improved the students' meaning making of conceptual understanding in mathematics, especially about the meaning making of fractions (see Figures 1 and 2). In this way, the sociocultural aspects supported the deepening of mathematical thinking and, at the same time, broadened the students' perspective of fractions. Through collaborative mathematical thinking, students promoted sustainability in their own mathematical thinking and professional development in mathematics (cf. (Widiaty and Juandi 2019)). Collaborative mathematical thinking has connected ALM with 21st Century competences. Pair-working in the research situations included fields of the 21st Century competences subareas: civic literacy, global awareness, and cross-cultural skills; critical and inventive thinking; and communication, collaboration and information skills. In the meaning making situations, students had to use civic literary (languaging), global awareness and cross-cultural skills (different learners worked together), critical and inventive thinking (meaning making for " $2 / 3$ "), collaboration (collaborative mathematical thinking), and information skills (multimodality in expressing mathematical thinking) (cf. Figure 1). Based on our study, we noted that during teacher education, prospective class teachers should have experiences (e.g., collaborative mathematical thinking, languaging) that promote their mathematical knowledge and understanding and contribute to the building of their and future generations' basis of sustainable mathematics understanding. In addition, this will support sustainable education and 21st Century competences. We summarize, in Table 4, the factors that support the understanding of key concepts and concept networks in mathematics education from the perspective of 21st Century skills. The objectives presented in Table 4 are objectives for both teacher education, teachers, and students, and they support ALM and ESD in mathematics learning (See Figures 1 and 2). 
Table 4. Sustainable development goals for teacher education, teachers and students in mathematics teaching and studies.

Understanding Learning of Mathematical Concepts And Concept Networks

\begin{tabular}{|c|c|c|}
\hline 21st Century Competences & Teacher & Student \\
\hline Contextualization & & \\
\hline $\begin{array}{l}\text { - Global awareness and } \\
\text { cross-cultural skills }\end{array}$ & $\begin{array}{l}\text { - } \quad \text { to understand students' } \\
\text { cultural knowledge and its } \\
\text { use in constructing the } \\
\text { meanings of mathematical } \\
\text { concepts (in } \\
\text { meaning making) } \\
\text { to contextualize } \\
\text { mathematical concepts in } \\
\text { phenomena familiar } \\
\text { to students }\end{array}$ & $\begin{array}{l}\text { - } \quad \text { to highlight contextualization } \\
\text { in own examples and } \\
\text { self-invented assignments } \\
\text { in relation to mathematical } \\
\text { concepts at hand }\end{array}$ \\
\hline
\end{tabular}

\section{Mathematical thinking}

- Critical and Innovative thinking

- $\quad$ critical use of the textbook in teaching

- $\quad$ to create and tailor appropriate teaching approaches on mathematical concepts to be studied for students and small groups
- the courage to question and to ask questions about mathematical concepts and solutions

- $\quad$ to create analogies and applications of the mathematical concepts to be studied
Languaging

- Communication

- Collaborative and information skills
- $\quad$ to understand languaging as a teaching model

- $\quad$ to work together on concept building, problem solving and game-based learning

- functional learning as part of the concept understanding process to describe concepts and solution processes in their own words (including by pictures) to build knowledge together with a peer group to give constructive feedback to others (to other students or to peer group etc.)

From a teacher's standpoint, contextualization (see Table 4) means that a teacher's knowledge of his/her students' mathematical skills must be good in order to contextualize mathematical concepts in phenomena that are familiar to students. When the learning atmosphere is good and a teacher knows his/her students, the teacher can focus on the potential for progress in what students say and do. Therefore, the students are free to bring multiple perspectives to learning situations, 
e.g., by contextualizing their own examples and self-invented assignments in relation to the mathematical concepts at hand, and also interpreting mathematics as a tool for understanding, analyzing, and solving the problems in the neighborhood and surrounding society (cf.Widiaty and Juandi 2019). Often (e.g., in Finland) mathematics teaching is 'textbook driven'. Due to this, the nature of mathematics and the contents of school mathematics might appear for pupils only through textbooks. Then, there is no room left for the pupils to question and to ask questions about mathematical concepts and solutions and express their own thinking (cf. Joutsenlahti and Perkkilä 2019). The critical use of the textbook in teaching (see Table 4) gives students more time and space to question and to ask questions about mathematical concepts and solutions. Students also have time to construct their own mathematical concepts solution processes and create analogies and applications for the mathematical concepts to be studied. Asking questions, reasoning, logical thought, creating analogies and applications for mathematical concepts, describing and explaining, and justification are closely related to conceptual understanding, which is one of the five intertwined strands of the description of mathematical proficiency (see Kilpatrick et al. 2001; Moschkovich 2019). As mentioned in Section 2.1.1, mathematical proficiency includes following intertwined strands: procedural fluency, strategic competence, adaptive reasoning, and productive disposition (see Figures 1 and 2). These strands are included in Table 4. Languaging as a teaching method provides teachers and students space to express and explain mathematical concepts in versatile ways. Therefore, codeswitching can serve as a resource during teaching and learning (tactile functional language, pictorial language, natural language, and mathematical symbolic language; see Figure 3). Languaging of mathematical thinking helps students to analyze and structure their thinking and, in that way, understand mathematical concepts, procedures, and solution processes (Joutsenlahti and Perkkilä 2019; Kilpatrick et al. 2001; Moschkovich 2015b). From the sociocultural perspective, we can think that languaging as a teaching model involves students in discipline-based practices in mathematics learning situations that involve reasoning and justification, sharing different views, understanding, and communication. Collaborative mathematical thinking is involved in languaging situations, and by working in small groups or in pairs, students share their ideas with each other, produce their joint solutions and learn to give feedback to each other. In Table 4, the sustainable development goals for teacher education, teachers, and students in mathematics teaching and studies involve the elements of ALM. These goals are created to give tools for teaching and learning mathematical concepts and mathematical networks in sustainable ways. ALM supports ESD and 21st Century competences but, on the other hand, ESD and 
21st Century competences also challenge ALM skills (see Figure 1). The goals in Table 4 give versatile ways to build a solid mathematical knowledge base, so that teacher education, teachers, and students can have better tools to solve and model ESD-based mathematical problems, e.g., in the social, economic, and environmental fields. The results (e.g., in Table 4) could be a base for mathematics education for a new curriculum of teacher education in universities.

Author Contributions: The authors contributed equally to this work.

Conflicts of Interest: The authors declare no conflict of interest.

\section{References}

Common Core State Standards. 2019. Common Core State Standards for Mathematical Practice. 2010 uptated 2019. Available online: http://www.corestandards.org/Math/Practice/ (accessed on 23 September 2019).

Díez-Palomar, Javier, Ainhoa Flecha, Fernández de Sanmamed, Rocío García-Carrión, and Silvia Molina-Roldán. 2018. Pathways to equitable and sustainable education through the inclusion of roma students in learning mathematics. Sustainability 10: 2191. [CrossRef]

Flitner, Wilhelm. 1970. Johann Amos Comenius. Didactica Magna. Düsseldorf: Helmut Küpper. Fullan, Michael. 2006. The future of educational change: System thinkers in action. Journal of Educational Change 7: 113-122. [CrossRef]

Hargreaves, Andy, and Dean Fink. 2003. Sustaining leadership. Phi Delta Kappan 84: 693-700. [CrossRef]

Hellström, Martti, Peter Johnson, Asko Leppilampi, and Pasi Sahlberg. 2015. Yhdessä oppiminen. Yhteistoiminnallisuuden käytäntö ja perusteet. Helsinki: Into. (In Finnish)

Joutsenlahti, Jorma. 2005. Lukiolaisen tehtäväorientoituneen matemaattisen ajattelun piirteitä: 1990-luvun pitkän matematiikan opiskelijoiden matemaattisen osaamisen ja uskomusten ilmentämänä. Doctoral thesis, Tampereen yliopisto, Tampere, Suomi. Acta Universitatis Tamperensis 1061. Available online: https:/trepo.tuni.fi/bitstream/handle/10024/67453/ 951-44-6204-1.pdf?sequence=1\&isAllowed=y (accessed on 20 October 2019). (In Finnish). Joutsenlahti, Jorma, and Pirjo Kulju. 2016. Akateeminen lukutaito matematiikassa. In Annual Symposium of the Finnish Mathematics and Science Education Research Association, University of Turku, Finland, October 29-30. Edited by Harry Silfverberg and Peter Hästö. Helsinki: The Finnish Mathematics and Science Education Research Association, pp. 23-34. Available online: http://www.protsv.fi/mlseura/julkaisut/MALU2015_Final.pdf (accessed on 20 October 2019). (In Finnish) 
Joutsenlahti, Jorma, and Pirjo Kulju. 2017. Multimodal languaging as a pedagogical model-A case study of the concept of division in school mathematics. Education Sciences 7: 9. [CrossRef]

Joutsenlahti, Jorma, Perkkilä Päivi, and Timo Tossavainen. 2017. NÄYTTEITÄ MURTOLUVUN KÄSITTEESTÄ ERI AIKAKAUSIEN OPPIKIRJOISSA. FMSERA Journal 1: 99-109. Available online: https://journal.fi/fmsera/article/view/60904 (accessed on 31 October 2019). (In Finnish).

Joutsenlahti, Jorma, and Kaisu Rättyä. 2015. Kielentämisen käsite ainedidaktisissa tutkimuksissa. In Rajaton Tulevaisuus. Kohti Kokonaisvaltaista Oppimista. Ainedidaktisia Tutkimuksia 8. Proceedings of the Didactics Symposium. University of Jyväskylä, Finland, February 13-14, 2014. Edited by Merja Kauppinen, Matti Rautiainen and Mirja Tarnanen. Jyväskylä: Suomen ainedidaktinen tutkimusseura, pp. 45-61. (In Finnish)

Joutsenlahti, Jorma, and Päivi Perkkilä. 2019. Sustainability development in mathematics education-A case study of what kind of meanings do prospective class teachers find for the mathematical symbol "2/3"? Sustainability 11: 457. [CrossRef]

Kalantzis, Mart, and Bill Cope. 2012. Literacies. Cambridge: Cambridge University Press.

Kilpatrick, Jeremy, Jane Swafford, and Bradford Findell. 2001. Adding It Up: Helping Children Learn Mathematics. National Research Council. Washington: National Academy Press.

Kieren, Thomas E. 1976. On the mathematical, cognitive, and instructional foundations of rational numbers. In Number and Measurement: Papers from a Research Workshop. Edited by Richard A. Lesh. Columbus: ERIC/SMEAC, pp. 101-44.

Klein, Jacob. 1968. Greek Mathematical thought and the Origin of Algebra. Cambridge: M.I.T. Press. Kupiainen, Reijo, Pirjo Kulju, and Marita Mäkinen. 2015. Mikä monilukutaito? In Monilukutaito Kaikki Kaikessa. Edited by Tapani Kaartinen. Tampere: Tampereen Yliopiston Normaalikoulu, pp. 13-24. (In Finnish)

Lemke, Jay. 2002. Mathematics in the Middle: Measure, Picture, Gesture, Sign and Word. In Educational Perspectives on Mathematics as Semiosis: From Thinking to Interpreting to Knowing. Edited by Andersson Myrdene, Adalira Saenz-Ludlow, Shea Zellweger and Victor Cifarelli. Ottawa: Legas Publishing, pp. 215-43.

Ministry of Education Singapore. 2018. 21st Competences. Last updated 11 October 2018. Available online: https:/www.moe.gov.sg/education/education-system/21st-centurycompetences (accessed on 20 October 2019).

Moschkovich, Judit N. 2015a. Academic literacy in mathematics for English learners. The Journal of Mathematical Behavior 40: 43-62. [CrossRef]

Moschkovich, Judit N. 2015b. A sociocultural approach to academic literacy in mathematics for adolescent English learners: Integrating mathematical proficiency, practices, and discourse. In Multilingual Learners and Academic Literacies: Sociocultural Contexts of Literacy Development in Adolescents. Edited by Daniella Molle, Edynn Sato, Timothy Boals and Carol A. Hedgspeth. New York: Routledge, pp. 75-104. 
Moschkovich, Judit N. 2019. Codeswitching and mathematics learners: How hybrid language practices provide resources for student participation in mathematical practices. In switching and mathematics learners: How hybrid language practices provide resources for student participation in mathematical practices. In Codeswitching in the Classroom. Critical Perspectives on Teaching, Learning, Policy, and Ideology. Language Education Tensions in Global and Local Contexts. Publications of Center for Applied Linguistics (CAL). Edited by Jeff MacSwan and Christian J. Faltis. Newyork: Routledge. [CrossRef]

Moschkovich, Judit N., and William Zahner. 2018. Using the academic literacy in mathematics framework to uncover multiple aspects of activity during peer mathematical discussions. ZBM 50: 999-1011. [CrossRef]

Morgan, Candia. 2001. The place of pupil writing in learning, teaching and assessing mathematics. In Issues in Mathematics Teaching. Edited by Peter Gates. London: Routledge, pp. 234-44.

Martin, Michael O., Ina VS Mullis, and Pierre Foy. 2008. TIMSS 2007 International Mathematics Report: Findings from IEA's Trends in International Mathematics and Science Study at the Fourth and Eighth Grades. Boston College, Chestnut Hill: International Association for the Evaluation of Educational Achievement (IEA).

Pantziara, Marilena, and George Philippou. 2012. Levels of students' conception of fractions. Educatonal studies in mathematics 79: 61-68. [CrossRef]

Park, Jungeun, Beste Gúçler, and Raven McGrory. 2013. Teaching prospective teachers about fractions: historical and pedagogical perspectives. Educational Studies in Mathematics 82: 455-79. [CrossRef]

Partnership for 21st Century Learning. 2019. Available online: http://www.battelleforkids.org/ networks/p21/frameworks-resources (accessed on 28 August 2019).

Perkkilä, Päivi. 2001. Oppikirja ja uskomukset alkuopettajien matematiikan opetuksessa. In Tutkimus Kouluopetuksen Kehittämisessä. Publications of the Faculty of Education 17. Edited by Aija Ahtineva. Turku: University of Turku, pp. 112-25. (In Finnish)

Shaughnessy, Meghan M. 2005. Students' Flexible Use of Multiple Representations for Rational Number: Decimals, Fractions, Parts of Area, and Number Lines. Doctoral thesis, University of California, Berkeley, USA. Available online: https:/search.proquest.com/ docview/304834330?pq-origsite=gscholar (accessed on 2 September 2019).

Siegler, Robert S., Lisa K. Fazio, Drew. H. Bailey, and Xhou Zhou. 2013. Fractions: the new frontier for theories for numerical development. Trends in Cognitive Sciences 17: 13-19. [CrossRef] [PubMed]

Shulman, Lee S. 1986. Those who understand: Knowledge growth in teaching. Educational Researcher 15: 4-14. [CrossRef] 
Stewart, Veon. 2005. Making Sense of Students' Understanding of Fractions: An Exploratory Study of Sixth Graders' Construction of Fraction Concepts through the Use of Physical Referents and Real World Representations. Doctoral thesis, The Florida State University. College of Education, October 12. Available online: https://diginole.lib.fsu.edu/islandora/ object/fsu:168517/datastream/PDF/view (accessed on 12 October 2019).

UN. 2018. The 2030 Agenda for Sustainable Development. Sustainable Development Goals. Available online: https://sustainabledevelopment.un.org/post2015/summit (accessed on 25 September 2019).

Valli, Päivi, Päivi Perkkilä, and Raine Valli. 2014. Adult pre-service teachers applying 21st century skills in the practice. Athens Journal of Education 1: 115-29. [CrossRef]

Vosniadou, Stella. 1999. Conceptual change research: state of art and future directions. In New Perspectives on Conceptual Change. Edited by Wolfgang Schnotz, Stella Vosniadou and Mario Carretero. Amstertam: Elsevier, pp. 3-14.

Widiaty, Isma, and Dadang Juandi. 2019. Philosophy of mathematics education for sustainable development. Journal of Physics: Conference Series 1157: 022128. [CrossRef]

Zehetmeier, Stefan, and Kondrad Krainer. 2011. Ways of promoting the sustainability of mathematics teachers' professional development. ZDM Mathematics Education 43: 875-87. [CrossRef]

(C) 2021 by the author. Licensee MDPI, Basel, Switzerland. This article is an open access article distributed under the terms and conditions of the Creative Commons Attribution (CC BY) license (http://creativecommons.org/licenses/by/4.0/). 


\title{
Outstanding Performance or Reversal of Fortune in Burundi's Education System?
}

\author{
Yasmine Bekkouche and Philip Verwimp
}

\section{Introduction}

Since the success of the Millennium Development Goals to get children into school, the focus of the international community has been reoriented towards the quality of schooling. The fourth goal of the Sustainable Development Goals set by the UN targets exactly that. It wants the global community not only to make sure that children attend school, but that schools also offer adequate training in reading and mathematics, tools that form the basis for all further cognitive development of a child (UNESCO 2017).

Burundi forms an interesting case study, as it experienced a massive increase in enrolment in primary school, but access to good quality education was not equally distributed over the country. The capital and the southern provinces were privileged by former presidents who came from the south and belonged to the Tutsi minority. Since his ascent to power, President Nkurunziza, a Hutu from the northern province of Ngozi, during his first mandate (2005-2010) heading a coalition government, and after a landslide victory in his second (2010-2015) and third mandate (2015-2020), has directed public funding to the northern provinces, Ngozi province in particular. Recent work has demonstrated that the population in the north benefits at multiple levels. Jadin (2020) uses household panel data with three waves (1998-2007-2012) and shows how income from agricultural activities as well as from coffee harvest increased in the north after the second wave, but not in the south, whereas both parts were on a parallel trend prior to the second wave. Verwimp (2019) highlighted the strong increase in school test scores obtained by schools in the north in the Concours National from 2010 onwards.

Education data worldwide are the product of an administrative process aggregating pupil-, teacher-, school- and district-level data as well as data from countries' national budgets. Researchers, donors, agencies and policymakers rely on the accuracy of these data to inform future policies, to draw a picture of the current state of affairs, to compare the performance of their country with neighbors and so on. Moreover, even the availability and accuracy of education data does not mean that national policymakers will take the evidence to heart. While, generally speaking, 
there are no grounds not to have confidence in a country's education data, it often takes an outside look or evaluation to wake up national policymakers. This is all the more evident in the reactions to the results of the Program for International Student Assessment (PISA) in the national press, in particular when the results show that one's country is lagging behind compared to others.

In this study, we use an independent source of information on school quality and school test score data produced by the CONFEMEN (Conférence des ministres de l'Education des Etats et gouvernements de la Francophonie) Program for the Analysis of Education Systems (PASEC), in 2009 and in 2014, to find out if we are indeed witnessing a reversal of fortune in Burundi's northern versus southern provinces (see PASEC 2010, 2015, in the corresponding order). At the same time, we scrutinize Burundi's overall exceptional performance compared to other countries tested in PASEC (Programe d'Analyse des Systèmes Educatifs de la Confemen). This allows us not only to compare test score data over time, but also between countries, making these data a valuable source for the analysis of educational performance.

\section{Burundi's Education System}

The report issued by PASEC after the first collection of test score data (PASEC 2010) lists many constraints and deficiencies in Burundi's education system, including the small tax base to finance educational expenses as a result of the high level of poverty in the country, the high birth rate that puts pressure on the educational system, the lack of adequate infrastructure and educational material, and the low qualification of teachers. As a result of the presidential decision to abolish school fees in primary school a major step towards realizing universal access as stipulated in SDG 4-the school population increased from 1,000,000 pupils in 2004 to 1,800,000 in 2008 (PASEC 2010, p. 29), a massive increase for which the school system was unprepared and under resourced. Nevertheless, the number of teachers and schools in that period also increased by $50 \%$, keeping pace with the increase in pupils.

In Burundi, the first four years (out of six) of primary school are taught in Kirundi, the national language, a policy that has positively affected the retention and promotion of children in those grades. This can also be witnessed in the results of the PASEC tests run for literacy in Kirundi in the second grade. In fifth and sixth grade, however, all teaching is done in French, posing a strong hurdle for pupils and resulting in very high repetition and dropout rates.

On top of nationwide deficiencies in the education sector, Burundi is plagued by ethno-regional favoritism. At the end of the sixth grade, the Ministry of Education organizes a national test, the Concours National. Each year, the Ministry of Education 
sets a threshold depending on the number of seats available in the country's secondary school system. Even before the start of the civil war, much fewer seats were available annually than pupils competing for a seat in the Concours National. This was a very competitive and merit-based system in which only a select few would attend secondary school. Dunlop (2015), who interviewed Hutu and Tutsi adults on their school career for her MA thesis, writes that the Concours National favored Tutsi pupils because the latter were better prepared for the exam in better-funded schools. The 'objective' outcome of the exam made Tutsi pupils believe that Hutu were not interested in pursuing secondary education and preferred to stay on farms. When he came into power, president Nkurunziza was determined to change this.

While the Ministry uses the Concours National to regulate access to secondary school, it can be usefully employed to monitor deficiencies in learning and to follow-up policies that improve the quality of education. The test measures the abilities of pupils in 4 domains: mathematics, French, Kirundi and environmental science. The maximum one could obtain was 200 points, with 80 for the math part, 70 for French, 30 for Kirundi and 20 for environmental science. The latter was conceived as a combination of biology and geography. As Ntwari (2016, p. 19) points out in his doctoral dissertation there is no separate training offered in Burundi for science teachers, in contrast to math. This may limit adequate teaching and curriculum development in the domain of sustainable development.

\section{Data}

We are using two PASEC data collection efforts in this chapter, ${ }^{1}$ the first PASEC wave we use was implemented in more than 10 countries in the first decade of the new millennium (in Burundi in 2009). The PASEC is an international program that measures the academic performance of children attending primary school in French speaking Sub-Saharan African countries. In each country, PASEC surveys a nationally representative sample of schools randomly selected from active primary schools. To represent the variety of schooling environments available in the country, each sample is stratified by regions and types of school (e.g., private and public schools). Once a school is sampled, one class of second grade and one class of fifth grade students are randomly selected, and 15 students are randomly drawn from each class to take the test. Since primary school across sub-Saharan Africa are organized around six grades, surveying pupils from the second and fifth grades is expected

1 PASEC. Available online: http://www.pasec.confemen.org/ (accessed on 29 April 2020). 
to yield a balanced image of numeracy and literacy skills near the entry and exit of primary education, while avoiding the peculiarities of the first and last grades.

Each student is assessed in language, arts and numeracy at the beginning and at the end of the academic year, using standardized tests made of multiple items in line with official curricula. At the end of the academic year, a teacher questionnaire provides further information on classroom organization and infrastructure, teacher characteristics, training, remuneration and literacy skills for each teacher. Similarly, the headmaster of each school is interviewed and provides detailed information on his/her characteristics, training, school infrastructure, pedagogical practices, and human resource practices.

The second PASEC test was done for all countries a few years later (in 2014). Three major modifications were applied. First, students were not sampled at the beginning of the school year anymore, but only at the end of the year instead. Second, students were tested in grade 6 instead of grade 5. Finally, the nature of the test itself changed: following the PISA methodology, the tests were designed to assess pupils' ability to achieve general objectives. For literacy, for instance, a general understanding of text and reading are tested. The methodology used to measure proficiency is based on Item Response Theory and uses plausible values. Consequently, PASEC 2014 tests are not directly comparable to PASEC 2009.

For the sake of comparability, we only used the end-of-the-year test in the first wave of PASEC. In the following, we refer to the tests implemented in grade 2 as "early primary" and those implemented in grade 5 (first wave) or grade 6 (second wave) as "late primary". Since the results of the two waves are not directly comparable, we first compare the relative performance of countries. Later in this chapter, we will use standardized test scores to compare different regions within Burundi.

In our analysis, we compare the following countries between the two waves: Burundi (2009 and 2014), Benin (2005 and 2014), Cameroon (2005 and 2014), Côte d'Ivoire (2009 and 2014), Senegal (2007 and 2014) and Tchad (2009 and 2014).

\section{Descriptive Statistics}

We start by plotting the results for the language and mathematics scores for PASEC 2009 in the second and fifth grades in Burundi and the other countries (Figure 1). In grade 2, compared to the other countries, Burundi has a low mean and low standard deviation on the French language test, meaning that practically everyone performs badly in the test. This comes as no surprise as the language of instruction in Burundi is Kirundi, the national language. French is not on the curriculum in grade 2. When we look at scores for the Kirundi test in grade 2, 
the mean improves but the standard deviation is much larger, meaning that some pupils do well and other do not. For the mathematics test, the mean is high and the standard deviation low, a situation that we term "Scandinavian type", as it means that everyone is doing well. The fact that mathematics is taught in Kirundi in the second grade may be the main explanation, as pupils are better able to understand the teacher.
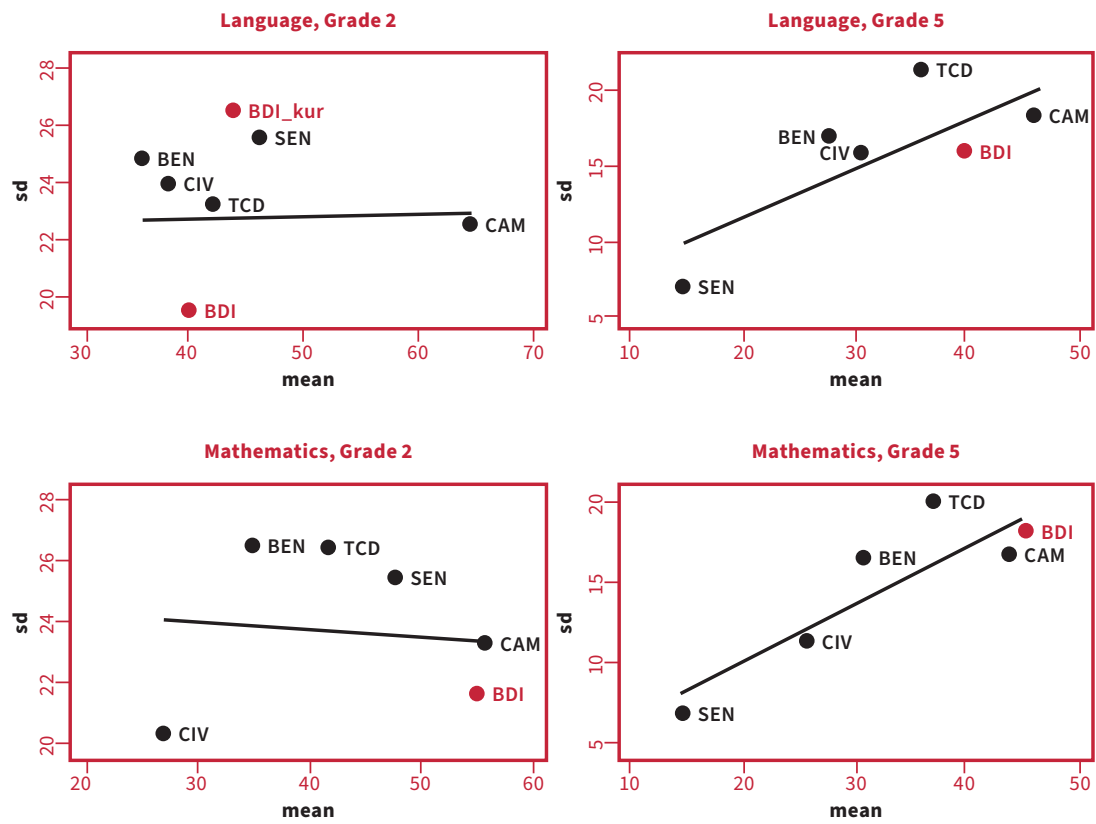

Figure 1. Mean and standard deviation for mathematics and language Program for the Analysis of Education Systems (PASEC) tests (2000s). Source: PASEC data for Burundi (2009), Benin (2005), Cameroon (2005), Côte d'Ivoire (2009), Senegal (2007) and Tchad (2009).

In grade 5, the mean and the standard deviation are both high, for mathematics as well as for language (which is solely French here), meaning that some but not all students do well. Importantly, we believe, in regard to the PASEC 2009 results for other countries, that the scores for Burundi cannot be considered outliers, neither for grade 2 nor for grade 5 . In both grades, the combination of the mean and standard deviation for Burundi is in the proximity of the linear fitted line, albeit more obvious in grade 5 compared to grade 2, with the caveat that the linear fit is performed only on a very small sample of countries. 
Turning our attention to PASEC 2014 (Figure 2), we notice the extremely positive scores for Burundi compared to other countries, meaning a very high mean and a low standard deviation. This is the most obvious in grade 6 , but also in grade 2, as can be witnessed in Figure 2, for language as well for mathematics. The scores for Burundi are so exceptional that the country is situated far from the linear fit-an outlier, in other words.
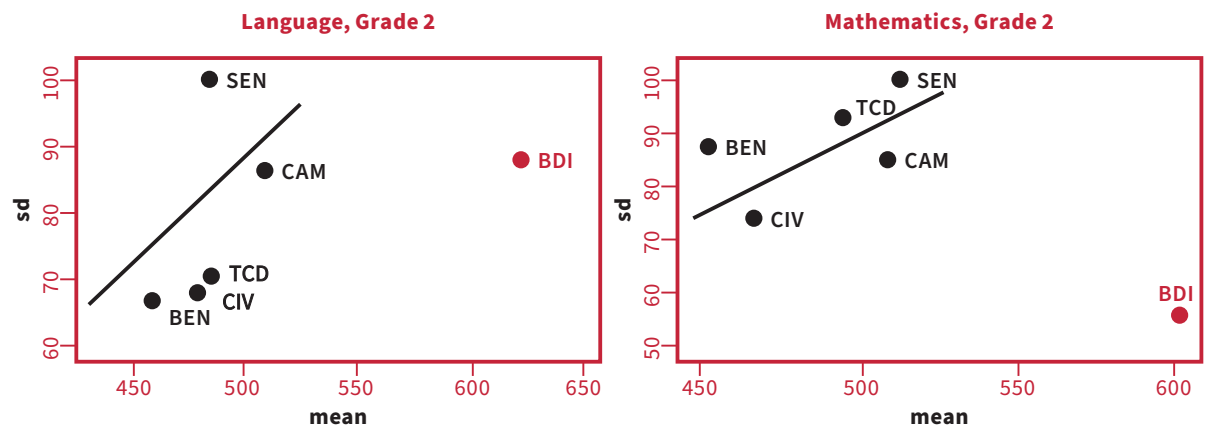

Language, Grade 2

Mathematics, Grade 6
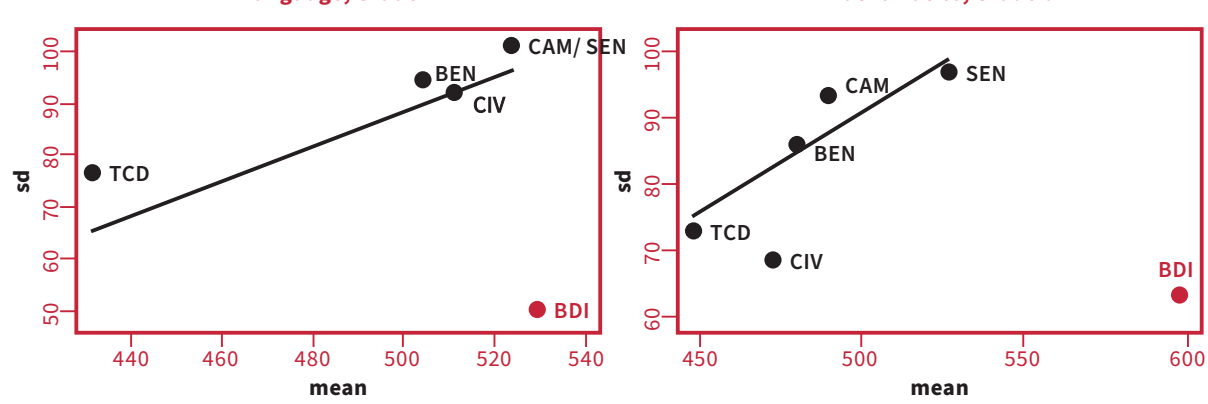

Figure 2. Mean and standard deviation for mathematics and language PASEC tests (2014)². Source: PASEC 2015.

2 The linear prediction lines does not include Burundi. 
When we compare test scores for grade 5 in PASEC 2009 with those for grade 6 in PASEC 2014 for those countries which took part in the test in both years, we notice that Cameroun, Benin and the Ivory Coast do not change much (meaning they demonstrate the same combination of mean and standard deviation), whereas the test scores for Chad deteriorate along the 45-degree axis (meaning that all students do worse in 2014 compared to 2009) and Senegal improves along the 45-degree axis. Burundi stands out as the only country that improves outside the 45-degree axis, meaning the mean score increases and the standard deviation decreases. For the language test, Burundi has the highest mean score combined with the lowest standard deviation of all countries. Since the test is testing the knowledge of French, and since French is the language of instruction only in the final two years of Burundi's primary school, this is an extraordinary performance. This is also the case for mathematics: the mean score for Burundi is also the highest of all countries, by a large margin, and Burundi also has the lowest standard deviation.

\section{Difference in Differences Analysis}

Upon disaggregating the test scores for Burundi for northern provinces versus southern provinces, we notice that the strong improvements for Burundi (higher mean and lower standard deviation in 2014 compared to 2009 compared to other countries) are mainly driven by the outstanding performance in the northern provinces. This can be witnessed in Figure 3.

Taking the analysis a step further, we perform a difference in differences analysis whereby the PASEC test score results for 2009 serve as the baseline, where we compute the changes with 2014 in the north and in the south of the country. Later, we discuss the parallel trends assumption that we are making here and demonstrate that both parts of the country were indeed on a parallel trend prior to 2009.

The results in Table 1 show that pupils in the northern provinces of Burundi, in general, perform worse compared to the southern provinces and that the test scores in 2014 were lower compared to 2009. However, compared to the south, northern test scores improve much more in 2014, which we demonstrate with the statistical significance of the interaction effect (even if the proportion of the variance described by this model, represented by the R-squared statistics, is very low). 

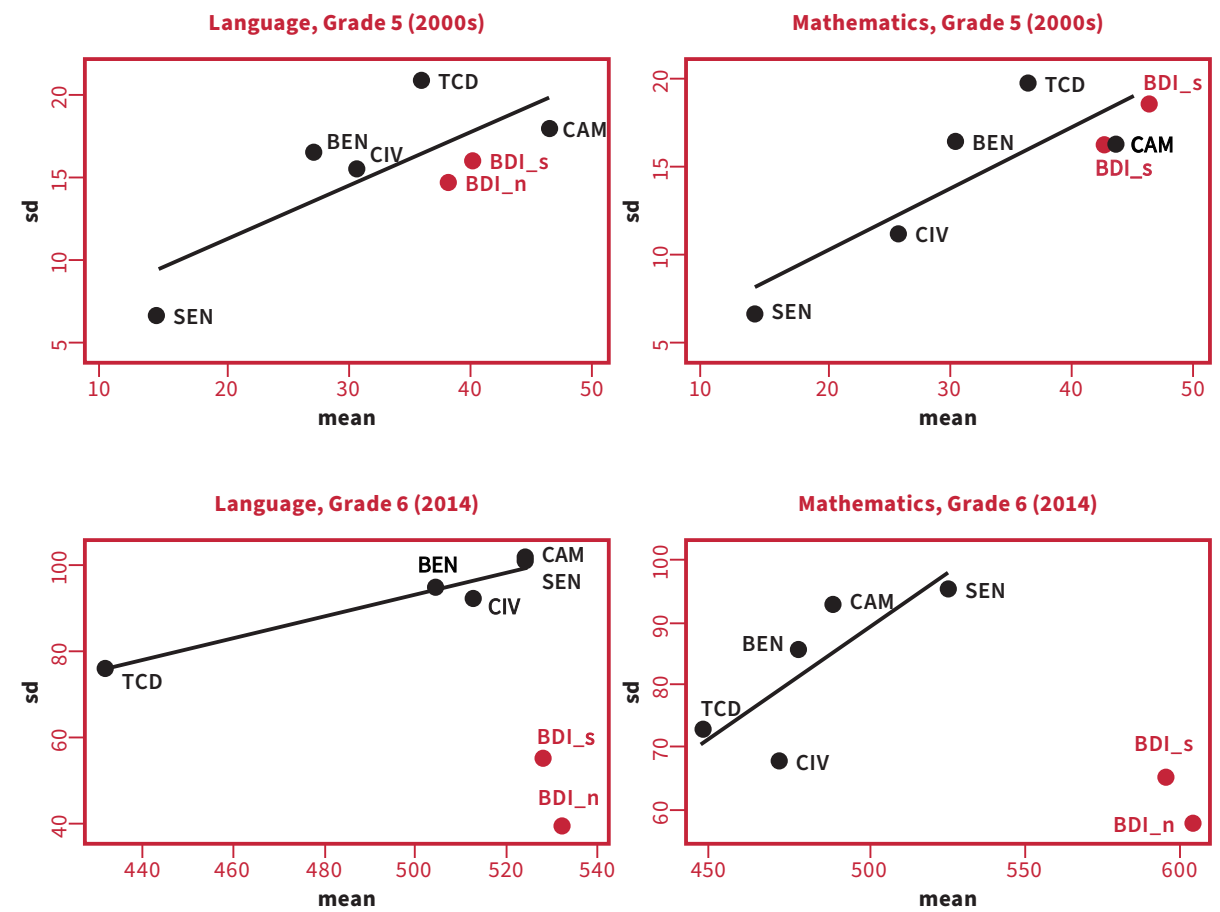

Figure 3. Mean and standard deviation in PASEC tests in late primary (for the 2014 results, the linear prediction line does not include Burundi). Source: PASEC data for Burundi (2009 and 2014), Benin (2005 and 2014), Cameroon (2005 and 2014), Côte d'Ivoire (2009 and 2014), Senegal (2007 and 2014) and Tchad (2009 and 2014). 
Table 1. Difference in difference estimation, late primary (standardized scores). Source: PASEC data for Burundi (2009 and 2014).

\begin{tabular}{cccc} 
& $(\mathbf{1})$ & $(\mathbf{3})$ & $(3)$ \\
& Total Score & Language & Mathematics \\
North * year 2014 & $0.30^{* *}$ & $0.25^{* * *}$ & $0.30^{* * *}$ \\
North & $(0.13)$ & $(0.06)$ & $(0.06)$ \\
Year 2014 & $-0.17^{*}$ & $-0.16^{* * *}$ & $-0.16^{* * *}$ \\
& $(0.10)$ & $(0.04)$ & $(0.04)$ \\
Constant & -0.09 & $-0.08^{* *}$ & $-0.09 * * *$ \\
& $(0.09)$ & $(0.03)$ & $(0.03)$ \\
Observations & 0.05 & $0.05^{* * *}$ & $0.05^{* *}$ \\
Adjusted_R-squared & $(0.07)$ & $(0.02)$ & $(0.02)$ \\
\hline
\end{tabular}

Note: regression of PASEC test scores on a constant, a dummy variable equal to 1 if the school of the student is located in the North region, a dummy equal to 1 if the student was studied in 2014 and a variable for the interaction of those 2 dummies. ${ }^{*} p<0.1,{ }^{* *} p<0.05,{ }^{* * *} p<0.01$.

\section{Parallel Trends before 2009}

Figure 3 depicts the evolution of test scores between 2009 and 2014 in Burundi, separated between northern and southern provinces. Before discussing the mechanisms behind this reversal of fortune, we want to point out that this is a particularity of this period, meaning that, before 2009, both parts were on a parallel trend and there was no sign of reversal. We demonstrate this in two graphs, depicted in Figure 4 where panel (b) depicts the PASEC scores for the north and south and panel (a) depicts the success rate in the Concours National for the years 2006, 2007 and 2008 in the schools sampled by PASEC during the 2009 test. Indeed, part of the data collection in 2009 by PASEC included the success rate of pupils in each sampled school in the three years prior to the test. The Concours National is a nationwide test, consisting of mathematics, French, Kirundi and environmental science that each pupil has to take if she/he wants to continue into secondary school. Hence, this constitutes an administrative source of information that is independent of PASEC and which allows us to corroborate the parallel trend in the north and the south before 2009 . 
a)

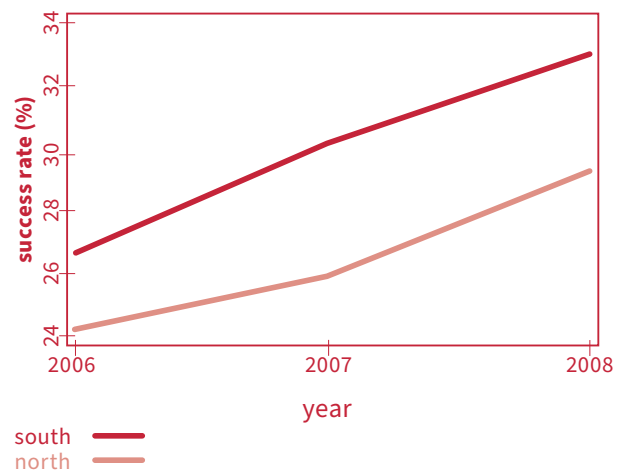

b)

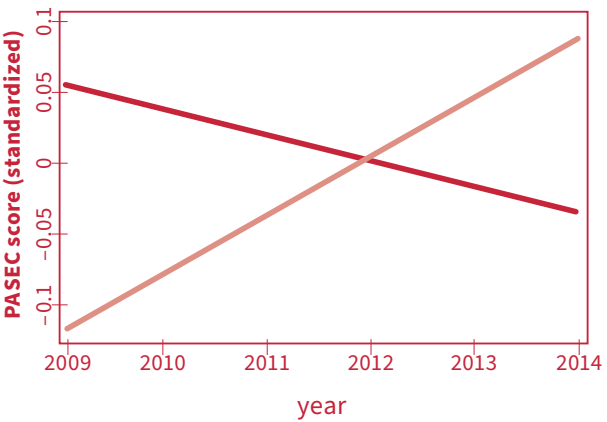

Figure 4. (a) Success rate in the Concours National, Burundi; (b) PASEC scores (2009 and 2014) in Burundi. Sources: PASEC data for Burundi (2009 and 2014) and results of the Concours National (Ministry of Education).

\section{Potential Mechanisms}

A number of reasons can explain the reversal of fortune of northern versus southern schools in Burundi's education system. As mentioned in the introduction, the north has been disadvantaged for several decades under the Tutsi-led regimes who favored their own southern region. By ending advantage and disadvantage, we could thus witness a return to long-term mean performance on both regions. Searching for variables that capture potential advantages and disadvantages, the PASEC data allows us to test several potential pathways. We introduce them one by one in the subsequent analysis. In Table 2, we first add school budgets, in nominal terms as well as on a per pupil basis. As expected, we find a small and statistically significant effect (at the 10\% level) of this variable, meaning that increases in school budgets play a role in test score performance. However, after controlling for this, neither the magnitude nor the statistical significance of our variable of interest (the interaction between the north and the 2014 test year) changes. This pattern is repeated when we control for two other variables which can be leveraged by educational policymakers in Burundi: the size of classes (again in nominal terms and per teacher), as well as school and class infrastructure. Both variables have the expected effect on test score performance (meaning negative for the effect of size and positive for the effect of infrastructure), but their inclusion does not change the effect of our variable of interest. 
Table 2. Difference in difference estimation mechanisms, late primary (standardized scores). Source: PASEC data for Burundi (2009 and 2014).

\begin{tabular}{|c|c|c|c|c|c|c|}
\hline & $\begin{array}{c}\text { (1) } \\
\text { Total } \\
\text { Score }\end{array}$ & $\begin{array}{c}\text { (2) } \\
\text { Total } \\
\text { Score }\end{array}$ & $\begin{array}{c}(3) \\
\text { Total } \\
\text { Score }\end{array}$ & $\begin{array}{c}\text { (4) } \\
\text { Total } \\
\text { Score }\end{array}$ & $\begin{array}{c}(5) \\
\text { Total } \\
\text { Score }\end{array}$ & $\begin{array}{c}\text { (6) } \\
\text { Total } \\
\text { Score }\end{array}$ \\
\hline Year 2014 & $\begin{array}{c}-0.16^{*} \\
(0.9)\end{array}$ & $\begin{array}{c}-0.15 \text { * } \\
(0.9)\end{array}$ & $\begin{array}{c}-0.21^{* *} \\
(0.9)\end{array}$ & $\begin{array}{c}-0.18 \text { * } \\
(0.10)\end{array}$ & $\begin{array}{l}-0.7 \\
(0.9)\end{array}$ & $\begin{array}{c}-0.21 * * \\
(0.9)\end{array}$ \\
\hline North & $\begin{array}{l}-0.16 \\
(0.10)\end{array}$ & $\begin{array}{l}-0.15 \\
(0.11)\end{array}$ & $\begin{array}{l}-0.16 \\
(0.10)\end{array}$ & $\begin{array}{l}-0.10 \\
(0.10)\end{array}$ & $\begin{array}{l}-0.19 * \\
(0.10)\end{array}$ & $\begin{array}{c}-0.13 \\
(0.9)\end{array}$ \\
\hline North * year 2014 & $\begin{array}{l}0.34^{* *} \\
(0.13)\end{array}$ & $\begin{array}{l}0.33 \text { ** } \\
(0.13)\end{array}$ & $\begin{array}{l}0.24^{*} \\
(0.13)\end{array}$ & $\begin{array}{l}0.30 \text { ** } \\
(0.13)\end{array}$ & $\begin{array}{c}0.26^{* *} \\
(0.13)\end{array}$ & $\begin{array}{c}0.25^{* *} \\
(0.13)\end{array}$ \\
\hline School budget & $\begin{array}{c}0.00^{* * *} \\
(0.00)\end{array}$ & & & & & \\
\hline Budget per student & & $\begin{array}{c}0.00 * * * \\
(0.00)\end{array}$ & & & & \\
\hline $\begin{array}{l}\text { Class size (dummy for } \\
\text { above median) }\end{array}$ & & & $\begin{array}{c}-0.01 * * * \\
(0.00)\end{array}$ & & & \\
\hline Student per teacher & & & & $\begin{array}{c}-0.01 \\
* * * * \\
(0.00)\end{array}$ & & \\
\hline School infrastructure & & & & & $\begin{array}{c}0.19^{* * *} \\
(0.06)\end{array}$ & \\
\hline Class infrastructure & & & & & & $\begin{array}{c}0.06^{* * *} \\
(002)\end{array}$ \\
\hline Constant & $\begin{array}{c}0.06 \\
(0.07)\end{array}$ & $\begin{array}{c}0.05 \\
(0.07)\end{array}$ & $\begin{array}{c}0.53^{* * *} \\
(0.12)\end{array}$ & $\begin{array}{c}0.39 * * * \\
(0.12)\end{array}$ & $\begin{array}{l}-0.21 * \\
(0.11)\end{array}$ & $\begin{array}{c}-0.31^{* * *} \\
(0.11)\end{array}$ \\
\hline Observations & 5321 & 5281 & 5687 & 5732 & 5804 & 5804 \\
\hline Adjusted_R-squared & 0.07 & 0.07 & 0.03 & 0.02 & 0.04 & 0.02 \\
\hline
\end{tabular}

Note: regression of PASEC test scores on a constant, a dummy variable equal to 1 if the school of the student is located in the North region, a dummy equal to 1 if the student was studied in 2014, a variable for the interaction of those 2 dummies and a series of possible mediators. ${ }^{*} p<0.1,{ }^{* *} p<0.05,{ }^{* * *} p<0.01$.

\section{Political Economy}

In Table 2, the interaction effect thus remains unexplained after the inclusion of a number of policy variables. We know, however, that the northern region is the area 
of origin of president Nkurunziza. As discussed in Verwimp (2019), an explanation of this reversal of fortune may also be found in the political arena. He showed that success rates in the Concours National changed dramatically from one year to the next in northern schools, after the landslide victory of the president's party in the parliamentary elections in 2010. Schools in Nkurunziza's municipality, a very poor area, score as good in the Concours National in 2010, 2011 and 2012 (period under investigation in Verwimp's paper) as the best performing schools in well-off neighborhoods in the capital Bujumbura, whereas, before 2010, this was not the case.

Since the second test run by PASEC took place in 2014 and since this test is run by an independent, international body running these tests in dozens of African countries, it may be that school quality and pupil performance in the north indeed improved between PASEC 2009 and PASEC 2014, in which case the improvements in the north can be the result of large investments over the last few years, and these improvements need not be the result of tinkering or political manipulation.

We are not able to determine the exact mechanisms that explain Burundi's very favorable scoring in the PASEC in 2014. It may be that the investment policies directed to the school system in the north under president Nkurunziza (more classrooms, more teachers, etc.) started paying off, as is also witnessed in our analysis. This may not explain the favorable test scores in the north one year later (2010, as in Verwimp (2019)), but may offer a plausible explanation 5 years later, in PASEC 2014. The unexplained part (the interaction effect in our analysis) may be caused by a motivational component compared to baseline observations in 2009-the combination of material improvements and immaterial ones (proudness, motivation, etc.) in the northern population, given that their plight is finally being answered by the president's policies.

\section{Discussion and Conclusions}

In the context of the learning crisis observed in many developing countries, Burundi stands as an outlier. When it comes to international skills assessments, Burundi students perform far better than other sub-Saharan African students, in both mathematics and language. Quite surprisingly, this is only the case for the 2014 PASEC survey. In this chapter, we studied potential explanations for this evolution. We suggest that this outstanding performance may be driven by a reversal of fortune within Burundi between northern and southern provinces, whereby the northern provinces did exceptionally well in PASEC 2014. The northern provinces, home turf of President Nkurunziza, have received a lot of public goods since his ascent to power. School budgets, class sizes and teachers per student have the expected effect 
in explaining the change in performance between PASEC 2009 and 2014. However, these elements do not seem to explain everything, as the northern dummy's interaction with the year 2014 dummy remains statistically significant after the inclusion of the above variables. This leaves the door open for other explanations of this progress, possibly related to the political economy or a motivational component.

As for the curriculum is concerned we recommend that Burundi builds on its experience with the inclusion of environmental science as a (small) part of the Concours Nationale. This offers a pathway to include sustainable development goals in the curriculum. It will require a strong effort on behalf of the teacher training institutes to educate future teachers who can build effective learning environments, another key element in SDG 4.

Author Contributions: Both authors contributed equally to this work.

Conflicts of Interest: The authors declare no conflict of interest.

\section{References}

Dunlop, Emily Alexandra. 2015. Ethnic Difference and Conflict in Burundian Schools: Experiences of Different Student Generations. Master's thesis, University of Toronto, Toronto, ON, Canada.

Jadin, J. 2020. Elite Capture and Labour Market Outcomes: Evidence from Burundi. Master's thesis, Université libre de Bruxelles, Bruxelles, Belgium.

Ntwari, Innocent. 2016. Connaissances Professionnelles Mobilisées et Besoins des Enseignants Pour la Mise en CEuvre du Curriculum de Mathématiques au 4ème cycle de l'École Fondamentale au Burundi (Élèves de 12 à 15 ans). Ph.D. thesis, Université Lumière Lyon 2, Lyon, France.

PASEC (Programme for the Analysis of Education Systems). 2010. Rapport PASEC Burundi 2008/2009. Enseignement Primaire: Quels défis pour une éducation de qualité en 2015? Dakar: PASEC/CONFEMEN, Available online: http://www.pasec.confemen.org/wp-content/ uploads/2015/07/08-Burundi.pdf (accessed on 29 April 2020).

PASEC (Programme for the Analysis of Education Systems). 2015. PASEC 2014: Education System Performance in Francophone Sub-Saharan Africa. Programme d'Analyse des Systèmes Educatifs de la CONFEMEN. Dakar: PASEC/CONFEMEN, Available online: https://www.pasec. confemen.org/wp-content/uploads/2015/12/Rapport_Pasec2014_GB_webv2.pdf (accessed on 29 April 2020). 
UNESCO. 2017. Global Education Monitoring Report: Accountability in Education. Meeting Our Commitments. Paris: UNESCO.

Verwimp, Philip. 2019. Ethno-Regional Favouritism and the Political Economy of School Test Scores. Working Paper 2019-28, Universite Libre de Bruxelles. ECARES, December. Available online: https://ideas.repec.org/p/eca/wpaper/2013-297162.html (accessed on 29 April 2020).

(C) 2021 by the authors. Licensee MDPI, Basel, Switzerland. This article is an open access article distributed under the terms and conditions of the Creative Commons Attribution (CC BY) license (http://creativecommons.org/licenses/by/4.0/). 
Integrating Sustainability Issues into Science Education through Career-Based Scenarios in the MultiCO Project

\author{
Tuula Keinonen, Katri Varis, Costas P. Constantinou, Miia Rannikmäe, \\ Annette Scheersoi and Shirley Simon
}

\title{
1. Introduction
}

School science education is recognised as an important area of study to comprehend the increasingly scientific world in which we live and to inspire students of all ages towards careers in science. Even more importantly, science education is appreciated for developing competences for the needs of future society, such as problem-solving and innovation, as well as analytical and critical thinking, seen as necessary to empower citizens to lead personally fulfilling, socially responsible and professionally engaging lives (European Commission 2015). However, students, especially those approaching adolescence, do not find science learning relevant (Stuckey et al. 2013). Students' declining interest towards science or the pursuit of science-related careers has been repeatedly highlighted in the science education research literature. Studies have reported that this negative trend of interest and aspirations in science starts at the end of primary school and evolves during lower secondary school years (Potvin and Hasni 2014; DeWitt and Archer 2015). A science career often requires an academic degree in a science-related or Science, Technology, Engineering, and Mathematics (STEM) field; thus, study aspiration in advanced science subjects at primary or lower-secondary school affects future career options (Sheldrake 2018). In addition, a growing need for students specialized in STEM is projected in the labour market and the proportion of STEM students in higher education is not expected to be sufficient (European Commission 2004, 2009; OECD 2008, 2017). Some mixed findings on students' interest have also been found; for instance, interest may increase significantly during the lower-secondary school phases, but there were no reciprocal relationships between interest and self-concept in predicting students' science aspirations (Kang et al. 2019).

The origin of the lack of interest or motivation, particularly in secondary science education, is seen to lie in pedagogical considerations (Potvin and Hasni 2014) and in socio-cultural capital. A major development, designed to attract young people to science studies and to raise scientific literacy among future citizens, has 
been to approach science education as 'education through the context of science' (European Commission 2007, 2015). Research has shown that context-based approaches in science education result in improvements in attitudes towards science (Bennett et al. 2007) and may lead to enhanced interest in science-related careers (Reid and Skryabina 2002). Teaching strategies that actively engage students in the learning process, such as through scientific investigations, strengthen conceptual understanding, and also have positive effects on students' attitudes towards science (Minner et al. 2010; Potvin and Hasni 2014). The use of models in upper secondary school was associated with a high level of situational engagement (Inkinen et al. 2020). At least one project-based course during the first four semesters affected college student STEM career aspirations (Beier et al. 2019).

Most European countries have recommended that science be taught in a context relating to contemporary societal issues (European Commission 2011; PARSEL Popularity and Relevance of Science Education for Scientific Literacy; PROFILES Professional Reflection-Oriented Focus on Inquiry-Based Learning and Education through Science; Bolte et al. 2012). Context-based science education, using cross-cutting themes, also has the opportunity to connect educational aims to several EU strategic priorities such as water resource management, raw materials, energy management, information and communication technologies (ICT), nutrition, health, and climate change. The MultiCO project has contributed to these trends in science education research by studying the impact of the introduction, for secondary school students (ages 13 to 15), of real life related, career-focused stories, referred to as scenarios. Scenarios initiate context- and inquiry-based science lessons and are intended to inform students' preferences for choosing science studies and increase their desire to reflect on an increased awareness of, and the attractiveness in pursuing, science-related careers. The project carried out a series of longitudinal studies of classroom interventions using motivational scenarios. These scenarios were created with multi-stakeholder co-operation between scientists in education, natural science, and experts from industry and civil society organisations, formal, as well as non-formal science educators and students. While a key aspect of the project was capturing the student viewpoint, research within the project heavily focused on producing evidence of the impact of interest and career-awareness on students' science study choices, and attitudes towards science-related careers.

In a broader sense, the MultiCO project created a mechanism for attractive science education, aiming to raise the number of future scientists that will be engaged in resolving major societal challenges related to sustainability issues, as well as strengthening the capacity of scientifically literate citizens to participate more 
meaningfully as decision-makers and social actors. This book chapter introduces how sustainability issues related to energy, water, waste, food, health, transport and climate change are incorporated in career-based scenarios for enhancing student motivation for science studies and science-related careers.

\section{Science Education and Sustainability}

Sustainability is widely recognised in school curricula as an important societal priority. For example, in the Finnish core curriculum, sustainability is included in one of the seven transversal competence areas, namely 'participation, involvement and building a sustainable future' (Finnish National Board of Education 2016). These competence areas epitomise the aims of education and reflect the competences needed in life. They are enacted through 'multidisciplinary learning modules' which integrate learning and increase the dialogue between different subjects. Schools organise one such module at least every school year. The core curriculum obliges schools to plan and implement these by making connections between different subjects (e.g., biology, chemistry, physics) and involving pupils in their planning. Apart from these obligations, the municipalities and schools have the freedom to plan the modules according to local needs and interests (Finnish National Board of Education 2016).

Sustainability can be promoted through a variety of pedagogical approaches. Widely, this is realised under the concept of Education for Sustainable Development (ESD). Researchers describe ESD with different terminology. However, there is an emerging consensus that ESD, as an approach in teaching, should deal with the complexity of a globalized world. The key principles of ESD are (UNESCO Education for Sustainable Development Goals 2017; UNESCO 2009, p. 26):

- A transformative and reflective process that seeks to integrate values and perceptions of sustainability into, not only education systems, but one's everyday personal and professional life;

- A means of empowering people with new knowledge and skills to help resolve common issues that challenge global society's collective life now and in the future;

- A holistic approach to achieve economic and social justice and respect for all life;

- A means to improve the quality of basic education, to reorient existing educational programmes and to raise awareness.

Similar focus in science education is on helping students become scientifically literate citizens who can participate in socio-scientific discourse (Hofstein et al. 2011) including sustainability issues. Particularly, the Societal Science Issues (SSI) approach 
seeks to promote goals in science education related to general interest and public understanding with particular reference to:

- Individual empowerment;

- Intellectual capabilities such as critical thinking, logical reasoning/analytical skills, creative problem-solving and decision-making;

- National and global citizenship;

- Socially responsible action by individuals and communities;

- Communication skills in a variety of forms; and

- $\quad$ Providing a skilled workforce for business and industry

(Aikenhead 1994, p. 49; Aikenhead 2000, p. 53; Rannikmäe 2002; Holbrook and Rannikmäe 2007; Havu-Nuutinen and Keinonen 2009).

Many of these skills can be addressed through argumentation activities, set in SSI contexts (Baytelman et al. 2020; Iordanou and Constantinou 2014; Ekborg et al. 2012; Simon et al. 2006; Simon and Richardson 2009). These skills, activities and pedagogical approaches are similar to those highlighted in ESD (Lozano et al. 2017; Bacon et al. 2011; Tilbury 2011; Laurie et al. 2016; United Nations 2015).

The strong relationship between ESD and quality education has been recognised by many leading organisations and scholars (Laurie et al. 2016). Quality education is identified as one of the seventeen Sustainable Development Goals (SDG, Goal 4) and education is a cross-cutting issue in many of the other 17 goals adopted in UN's agenda. SDG 4 focuses on ensuring inclusive and equitable quality education and promoting lifelong learning opportunities for all. According to Laurie et al. (2016), ESD contributes to a quality education when 'the curriculum includes sustainability content-delivered in terms of local, social, economic and environmental contexts'. The definition of quality education is constantly evolving and is always contextual (Laurie et al. 2016). Quality education makes content relevant in order to prepare students to enter community life and the workforce (UNESCO 2005).

The MultiCO project outcomes contribute to ESD and the target of SDG 4 promoting students' knowledge and skills for equal access for all to affordable and quality education. Through planning relevant science education for all to motivate young people for science studies, MultiCO aimed to increase the number of youth and adults who have relevant skills for employment, decent jobs, and entrepreneurship. The project contributed methods and tools to ensure that learners acquire the knowledge and skills needed to promote sustainable development, including, among others sustainable lifestyles, gender equality, global citizenship and appreciation of cultural diversity, as well as of culture's contribution to sustainable 
development. The project sought to clarify how the scenarios in the context-based approach stimulate students and relate to educational gains related to working life skills and responsible citizenship.

\section{Career Aspect in Science Education}

Potvin and Hasni (2014) found in their review that issues positively affecting interest, motivation and attitudes were associated with: role models or science and technology careers in interventions; students' self-efficacy; authentic tasks; contact with scientists and working collaboratively. One factor associated with greater probability of uptake of physics was expected performance. In addition, the manner in which courses were taught was important to the recruitment and retention of students in the STEM disciplines (Gill and Bell 2013). Another finding was that informal programmes influence study and career choices, but these needed to be longer, for example, lasting one year (Fadigan and Hammrich 2004). Ainley and Ainley (2011) suggested that efforts to increase the attractiveness of science to students should take heed of the fact that enjoyment of science had a central role in the paths linking personal value, interest and current science activities to intentions for future participation in science.

Students need knowledge about career opportunities to be able to make informed choices. Middle grade students are not often made aware of career options, and few indicate knowing professionals actively working in STEM or the environment fields (Maltese and Tai 2011). Several authors have proposed how different factors might influence career choice. Eccles (2009) suggests that self-related beliefs regarding both one's relative competences and the relative subjective task value are critical influences on behavioural choices. Andersen and Ward (2014) suggest that students need to be made more aware of the utility of science courses in relation to their future goals for careers and study plans. van Aalderen-Smeets et al. (2018) found that there is a positive relation between implicit STEM ability beliefs and the intention to opt for a STEM field bachelor's degree. Incremental STEM ability beliefs predicted positive self-efficacy beliefs and increased STEM intention.

Students' conceptions of careers were stable through at least several years of adolescence and early adulthood (Masnick et al. 2010). Masnick et al. also found that students had a strong perception that scientific careers are not particularly creative and did not involve much interaction with others. To increase the utility value of school science, providing students with information and advice about career options and the corresponding educational requirements was seen to be critical. Mau (2003) shows that academic proficiency and mathematics self-efficacy 
are the two strongest predictors of persistence in science and engineering careers. Lykkegaard and Ulriksen (2019) followed students during and after their completion of upper-secondary education and noticed that only $22 \%$ of students expressed the same interest during the whole period, and $56 \%$ changed between different groups of studies, e.g., between STEM and HEALTH. Students need accurate information about STEM careers and this information needs to be part of science curricula and high school career counselling (Holmegaard et al. 2014).

In the MultiCO project, it was assumed that career awareness and inquiries have together a positive effect on science interest and motivation towards science studies and should be promoted in unison. The career aspect was implemented using career-based scenarios. Scenarios are defined as motivational student-relevant constructs, expressed in words, which might also be illustrated/expanded by cartoons, graphics, videos, and/or presentation slides, related to an attractive problem, or issue, or an unexpected or extraordinary situation, with the possibility to involve students in an unusual scientific, hands-on activity (seen as relevant by students) and include career-related aspects. The problem, issue or situation is linked to EU challenges related to energy, water, waste, climate change, food, health, or transport issues.

The scenario is interesting to students in general and hence the scenario is not gender specific. The scenario needs to be "relevant in the eyes of the students" and not as perceived by the teacher. The scenario context is thus most likely connected with:

- Students' personal lives, either now or in the future (personal relevance);

- A social problem/issue or problems/issues, which may have a (hidden) science component (social relevance);

- Updated global or local problems/issues (media relevance).

The scenario is expected to be an initiator, leading to learning that is related to the intended science curriculum, both in terms of subject matter and general (cross-curricular) competences. The introductory scenario is expected to provide the rationale for gaining new knowledge and competences, as outlined in the curriculum, and thus needs to be anticipated as having a positive impact on students becoming intrinsically motivated.

A scenario may include for example:

1. An industry visit. The purpose of the visit can be descriptive, or problem-oriented.

2. A virtual scenario (e.g., a video showing work in industry, or a video of a visit pointing out different aspects of a career or a person's life).

3. A career story (given as a text, cartoon, or maybe role play, such as involving interviews). 
4. An issue (socio-scientific), or a problem (science-related), which includes career-related aspects.

5. A problem to be solved (industry linked, science-related).

The career aspect does not necessarily need to be directly presented in all cases. It can be latent in an industrial or in any other STEM related context. In this chapter, we present some of the MultiCO scenarios and what ESD aspects these scenarios include.

\section{Sustainability Included in the MultiCO Career-Based Scenarios}

The aim of this chapter is to show how sustainability is included in the MultiCO scenarios. Sustainability in the scenarios is evaluated based on the following ESD aspects, as already described in detail in the previous sections:

- Content (energy, water, waste, climate change, food, health and transport issues);

- Context (local, social, economic, and environmental);

- Pedagogy (for example inquiries, group work, real-world problem solving);

- Skills (collaboration, communication, scientific reasoning, creativity, based on the MultiCO aims).

The project has published 32 scenarios, all of which are openly accessible. ${ }^{1}$ Out of these, 27 scenarios have a significant relationship to sustainability and are presented in this chapter. The connections are shown in Tables 1-5. Because the project focused on raising scientific career awareness, the career aspect is also shown in Tables 1-5, besides the content, context, pedagogy, and skills. Other scenarios not mentioned here may also include sustainability issues depending on how a teacher chooses to implement the scenarios.

The scenarios introduce careers and sustainability aspects in a variety of ways. Next, we present some of the scenarios. For example, the scenario Chemical Design Engineer, created by the University College London team, introduces an expert, Nadina, her work and the working life skills needed in her job (Figure 1). This is one way to raise students' career awareness. Following the scenario, the students are given a task to design products that minimise sports injury: "Your latest task is to design two instant sports injury packs" (Figure 1). The sports injury problem can be interpreted to be global and social, addressing issues pertaining to health

1 See MultiCO. Available online: www.multico-project.eu (accessed on 6 August 2019). 
and wellbeing. Students are asked to take the role of an expert and use scientific information in order to formulate realistic specifications and design the products. This task calls for creativity and scientific thinking. It is expected that students work in collaboration and they need to reason in their designs.

Table 1. MultiCO scenarios and their sustainability aspects in Cyprus.

\begin{tabular}{|c|c|c|c|c|c|}
\hline Scenario Title & Content & Career Aspect & Context/Socio-Scientific Issue & Pedagogy & Skills \\
\hline Acoustics Club & Waves and Sound & $\begin{array}{c}\text { Acoustic/sound } \\
\text { engineer, } \\
\text { Mechanical engineer, } \\
\text { Physicist }\end{array}$ & $\begin{array}{c}\text { Local, Social and Environmental/ } \\
\text { Club for teenagers, Noise/ } \\
\text { Health }\end{array}$ & $\begin{array}{l}\text { Real world } \\
\text { problem } \\
\text { solving }\end{array}$ & $\begin{array}{l}\text { Collaboration, } \\
\text { Creativity, } \\
\text { Reasoning }\end{array}$ \\
\hline Fly if you can & $\begin{array}{c}\text { Motion Newton's, } \\
\text { laws }\end{array}$ & $\begin{array}{l}\text { Aeronautical \& } \\
\text { aircraft engineer, } \\
\text { Mechanical \& } \\
\text { electrical engineer }\end{array}$ & $\begin{array}{l}\text { Global, Economic, Environmental/ } \\
\text { Emergency landing problems/ } \\
\text { Climate Change, Transport }\end{array}$ & $\begin{array}{l}\text { Design, } \\
\text { Competition, } \\
\text { Group work }\end{array}$ & $\begin{array}{l}\text { Creativity, } \\
\text { Collaboration }\end{array}$ \\
\hline Nuclear Decisions & $\begin{array}{c}\text { Sustainable } \\
\text { development }\end{array}$ & $\begin{array}{l}\text { Geologist, } \\
\text { Environmentalist, } \\
\text { Hydrologist, } \\
\text { Seismologist, } \\
\text { Meteorologist }\end{array}$ & $\begin{array}{c}\text { Global, Economic, Environmental/ } \\
\text { Location of the nuclear plant, } \\
\text { Environment Protection/ } \\
\text { Energy }\end{array}$ & $\begin{array}{l}\text { Problem } \\
\text { solving }\end{array}$ & $\begin{array}{c}\text { Communication, } \\
\text { Collaboration }\end{array}$ \\
\hline $\begin{array}{l}\text { Save the polar } \\
\text { bears! }\end{array}$ & $\begin{array}{l}\text { Heat transfer, } \\
\text { Conductors } \\
\text { Insulation }\end{array}$ & $\begin{array}{l}\text { Architects specialized } \\
\text { in energy-efficient } \\
\text { buildings }\end{array}$ & $\begin{array}{l}\text { Global, Social, Economic, } \\
\text { Environmental/ } \\
\text { Energy Efficiency/ } \\
\text { Climate Change, Energy }\end{array}$ & $\begin{array}{l}\text { Role play, } \\
\text { Design }\end{array}$ & $\begin{array}{l}\text { Reasoning, } \\
\text { Creativity }\end{array}$ \\
\hline $\begin{array}{l}\text { Two wheeled } \\
\text { mission }\end{array}$ & Speed and motion & Civil engineer & $\begin{array}{c}\text { Local, Social, Economic, } \\
\text { Environmental/ } \\
\text { Car emissions, Traffic congestion/ } \\
\text { Climate Change, Traffic }\end{array}$ & $\begin{array}{l}\text { Problem } \\
\text { solving, } \\
\text { Video }\end{array}$ & $\begin{array}{l}\text { Reasoning, } \\
\text { Decision making, } \\
\text { Collaboration }\end{array}$ \\
\hline $\begin{array}{l}\text { Zero plastics to } \\
\text { landfill by } 2020\end{array}$ & $\begin{array}{l}\text { Pure and impure } \\
\text { substances, } \\
\text { Process of } \\
\text { combustion } \\
\text { Sink and float }\end{array}$ & $\begin{array}{l}\text { Environmental } \\
\text { scientist }\end{array}$ & $\begin{array}{c}\text { Global, Social, Economic, } \\
\text { Environmental/ } \\
\text { Plastic waste, Recycling/ } \\
\text { Waste }\end{array}$ & $\begin{array}{c}\text { Cartoon, } \\
\text { Investigations }\end{array}$ & Collaboration \\
\hline
\end{tabular}

Table 2. MultiCO scenarios and their sustainability aspects in Estonia.

\begin{tabular}{|c|c|c|c|c|c|}
\hline Scenario Title & Content & Career Aspect & Context/Socio-Scientific Issue & Pedagogy & Skills \\
\hline $\begin{array}{l}\text { Electricity in } \\
\text { the air }\end{array}$ & $\begin{array}{l}\text { Electricity, } \\
\text { particles }\end{array}$ & $\begin{array}{c}\text { Engineer, Material } \\
\text { Scientist, } \\
\text { Environmental } \\
\text { Protection Specialist }\end{array}$ & $\begin{array}{l}\text { Global (Local), Social, Economic, } \\
\text { Environmental/ } \\
\text { Energy consumption and production, } \\
\quad \text { Solar power/ } \\
\text { Energy, Climate change }\end{array}$ & $\begin{array}{l}\text { Design, } \\
\text { Role play }\end{array}$ & $\begin{array}{l}\text { Creativity, } \\
\text { Collaboration, } \\
\text { Reasoning }\end{array}$ \\
\hline $\begin{array}{l}\text { Endangered } \\
\text { species }\end{array}$ & $\begin{array}{l}\text { Ecology, } \\
\text { poisoning } \\
\text { substances }\end{array}$ & $\begin{array}{l}\text { Customs officer, } \\
\text { Environmentalist, } \\
\text { Natural scientist, } \\
\text { Specialists of tourism } \\
\text { and finances }\end{array}$ & $\begin{array}{c}\text { Global, Social, Economic, } \\
\text { Environmental/ } \\
\text { International trade, Environmental } \\
\text { protection, Ethics and social } \\
\text { responsibility/ } \\
\text { Climate change, Transport }\end{array}$ & $\begin{array}{l}\text { Role play, } \\
\text { Group work }\end{array}$ & $\begin{array}{l}\text { Collaboration, } \\
\text { Communication, } \\
\text { Reasoning }\end{array}$ \\
\hline $\begin{array}{l}\text { Oil - the king of } \\
\text { the world or } \\
\text { Achilles heel? }\end{array}$ & $\begin{array}{l}\text { Heating value, } \\
\text { oil properties and } \\
\text { composition }\end{array}$ & $\begin{array}{l}\text { Chemist, } \\
\text { environmental expert, } \\
\text { journalists, zoologist }\end{array}$ & $\begin{array}{c}\text { Global, Social/ } \\
\text { Environmental protection/ } \\
\text { Climate change, Transport }\end{array}$ & Investigations & Collaboration \\
\hline $\begin{array}{l}\text { Should there be a } \\
\text { sugar tax? }\end{array}$ & $\begin{array}{c}\text { Titration, } \\
\text { Substance } \\
\text { identification, } \mathrm{pH}\end{array}$ & $\begin{array}{l}\text { Technologist, chemist, } \\
\text { bio-chemist }\end{array}$ & $\begin{array}{c}\text { Global, Social, Economic/ } \\
\text { Sugar tax/ } \\
\text { Health }\end{array}$ & $\begin{array}{l}\text { Debate, } \\
\text { Visit, } \\
\text { Interview }\end{array}$ & $\begin{array}{l}\text { Reasoning, } \\
\text { Collaboration, } \\
\text { Creativity }\end{array}$ \\
\hline
\end{tabular}


Table 3. MultiCO scenarios and their sustainability aspects in U.K.

\begin{tabular}{|c|c|c|c|c|c|}
\hline Scenario Title & Content & Career Aspect & $\begin{array}{l}\text { Context/Socio-Scientif } \\
\text { Issue }\end{array}$ & Pedagogy & Skills \\
\hline $\begin{array}{c}\text { Chemical design } \\
\text { engineer }\end{array}$ & $\begin{array}{l}\text { Energy in } \\
\text { reactions }\end{array}$ & $\begin{array}{l}\text { Chemical Design } \\
\text { Engineer }\end{array}$ & $\begin{array}{l}\text { Global, Social/Cold } \\
\text { pack planning, } \\
\text { Sport injuries, } \\
\text { Injuries/Health }\end{array}$ & $\begin{array}{l}\text { Role play, } \\
\text { Design }\end{array}$ & $\begin{array}{l}\text { Creativity, } \\
\text { Collaboration, } \\
\text { Reasoning }\end{array}$ \\
\hline $\begin{array}{l}\text { Lamb, lime and } \\
\text { mussels }\end{array}$ & Neutralisation & $\begin{array}{l}\text { Sheep farmer, } \\
\text { Aqua culturist, } \\
\text { Agronomist }\end{array}$ & $\begin{array}{c}\text { Local, Social, } \\
\text { Environmental/ } \\
\text { Waste } \\
\text { management/Climate } \\
\text { change, Food }\end{array}$ & $\begin{array}{l}\text { Role play, } \\
\text { investigations }\end{array}$ & Communication \\
\hline Nuclear medicine & Nuclear radiation & $\begin{array}{l}\text { Nuclear Medicine } \\
\text { Technologist }\end{array}$ & $\begin{array}{c}\text { Global, Social/ } \\
\text { Radioactive } \\
\text { substances/Health }\end{array}$ & $\begin{array}{l}\text { Role play, } \\
\text { Investigations }\end{array}$ & $\begin{array}{l}\text { Communication, } \\
\text { Reasoning }\end{array}$ \\
\hline Roundabout & $\begin{array}{l}\text { Sustainable } \\
\text { energy }\end{array}$ & Traffic Engineer & $\begin{array}{c}\text { Local, Social/ } \\
\text { Environmental/ } \\
\text { Participation in Society, } \\
\text { Traffic congestion/ } \\
\text { Climate change, } \\
\text { Traffic }\end{array}$ & $\begin{array}{c}\text { Surveys, } \\
\text { Participation }\end{array}$ & $\begin{array}{l}\text { Collaboration, } \\
\text { Reasoning }\end{array}$ \\
\hline
\end{tabular}

Table 4. MultiCO scenarios and their sustainability aspects in Finland.

\begin{tabular}{|c|c|c|c|c|c|}
\hline Scenario Title & Content & Career Aspect & $\begin{array}{c}\text { Context/Socio-Scientific } \\
\text { Issue }\end{array}$ & Pedagogy & Skills \\
\hline Blackout & $\begin{array}{l}\text { Generator, } \\
\text { Transformer, } \\
\text { Electric grid }\end{array}$ & $\begin{array}{l}\text { Electrician, forester, staff } \\
\text { manager, purchasing } \\
\text { manager, production } \\
\text { manager, customer service, } \\
\text { process operator, power } \\
\text { network designer }\end{array}$ & $\begin{array}{l}\text { Local (Global), Social, } \\
\text { Environmental/ } \\
\text { Blackout, Electric grid/ } \\
\text { Energy }\end{array}$ & Group work, Play & $\begin{array}{l}\text { Collaboration, } \\
\text { Reasoning }\end{array}$ \\
\hline Car park & Velocity & Project engineer & $\begin{array}{l}\text { Local, Social, Environmental/ } \\
\text { City and traffic planning, Noise } \\
\text { and air pollution/ } \\
\text { Climate change, Transport }\end{array}$ & $\begin{array}{l}\text { Visit in } \\
\text { construction site }\end{array}$ & $\begin{array}{l}\text { Collaboration, } \\
\text { Reasoning }\end{array}$ \\
\hline Coal to the teeth & $\begin{array}{l}\text { Activated carbon, } \\
\text { Acid erosion }(\mathrm{pH})\end{array}$ & Dentist, chemist & $\begin{array}{c}\text { Local (Global), Social/Teeth } \\
\text { whitening/Health }\end{array}$ & $\begin{array}{l}\text { Real world } \\
\text { problem solving, } \\
\text { Collaboration } \\
\text { with dentist }\end{array}$ & $\begin{array}{c}\text { Collaboration, } \\
\text { Reasoning, } \\
\text { Communication }\end{array}$ \\
\hline Life cycle & $\begin{array}{l}\text { Product's life } \\
\text { cycle }\end{array}$ & $\begin{array}{l}\text { Experts chosen by the } \\
\text { students related to the } \\
\text { product }\end{array}$ & $\begin{array}{l}\text { Local, Social, Economic, } \\
\text { Environmental/ } \\
\text { Life cycle/Waste, Energy, } \\
\text { Water, Climate Change }\end{array}$ & $\begin{array}{l}\text { Video (Youtube), } \\
\text { Interview }\end{array}$ & $\begin{array}{c}\text { Reasoning, } \\
\text { Communication }\end{array}$ \\
\hline Old pipes found & $\begin{array}{l}\text { Thermal } \\
\text { expansion }\end{array}$ & NC-machinist, calibrator & Local/Recycling/Waste & $\begin{array}{c}\text { Visit, } \\
\text { Investigations }\end{array}$ & $\begin{array}{l}\text { Collaboration, } \\
\text { Communication, } \\
\text { Reasoning }\end{array}$ \\
\hline $\begin{array}{l}\text { Pedestrian } \\
\text { crossing }\end{array}$ & Velocity & Municipal engineering & $\begin{array}{c}\text { Local/ } \\
\text { Participation in Society/Safety, } \\
\text { Transport }\end{array}$ & $\begin{array}{l}\text { Investigations, } \\
\text { Participation }\end{array}$ & $\begin{array}{l}\text { Collaboration, } \\
\text { Reasoning }\end{array}$ \\
\hline Recruitment fair & Electrolysis & $\begin{array}{c}\text { Prototype producer, } \\
\text { machinist } \\
\text { CNC-machinist, laboratorian, } \\
\text { task organizer }\end{array}$ & $\begin{array}{c}\text { Local/ } \\
\text { Working life/Safety }\end{array}$ & Visit, Role play & Reasoning \\
\hline Sport physician & $\begin{array}{l}\text { Thermal } \\
\text { equilibrium }\end{array}$ & Sport physician, Doctor & $\begin{array}{l}\text { Global, Social/ } \\
\text { Heat problems/ } \\
\text { Health }\end{array}$ & Mind map & $\begin{array}{l}\text { Reasoning, } \\
\text { Collaboration }\end{array}$ \\
\hline Water purification & $\begin{array}{l}\text { Soluble-insoluble, } \\
\text { Separation } \\
\text { methods }\end{array}$ & Chemist, municipal engineer & $\begin{array}{l}\text { Local, Environmental/Water } \\
\text { supply/ Climate change, } \\
\text { Water }\end{array}$ & $\begin{array}{l}\text { Problem solving, } \\
\text { Meeting a chemist }\end{array}$ & $\begin{array}{l}\text { Creativity, } \\
\text { Collaboration, } \\
\text { Reasoning }\end{array}$ \\
\hline
\end{tabular}


Table 5. MultiCO scenarios and their sustainability aspects in Germany.

\begin{tabular}{|c|c|c|c|c|c|}
\hline Scenario Title & Content & Career Aspect & $\begin{array}{c}\text { Context/Socio-Scientif } \\
\text { Issue }\end{array}$ & Pedagogy & Skills \\
\hline Crime scene & $\begin{array}{c}\text { Electricity, electric } \\
\text { shock, safety at } \\
\text { home }\end{array}$ & $\begin{array}{c}\text { Electrician, } \\
\text { Horticulturist, } \\
\text { Forensic chemist, } \\
\text { Zoologist, Pharmacist }\end{array}$ & $\begin{array}{l}\text { Local, Social/ } \\
\text { Safety/ } \\
\text { Health }\end{array}$ & $\begin{array}{l}\text { Problem } \\
\text { solving }\end{array}$ & Reasoning \\
\hline Road salt & Salts & $\begin{array}{l}\text { Chemist, CEO in } \\
\text { industry, Sales } \\
\text { Manager industrial, } \\
\text { Chemical technician }\end{array}$ & $\begin{array}{c}\text { Local, Social, } \\
\text { Environmental/ } \\
\text { Ice problems/ Climate } \\
\text { change, Traffic }\end{array}$ & $\begin{array}{l}\text { Investigations, } \\
\text { Group work }\end{array}$ & $\begin{array}{l}\text { Creativity, } \\
\text { Collaboration, } \\
\text { Reasoning }\end{array}$ \\
\hline Forester & Ecology & $\begin{array}{l}\text { Forester, Forest } \\
\text { engineer }\end{array}$ & $\begin{array}{c}\text { Local, Environmental, } \\
\text { Economic/ } \\
\text { Forest use vs. Forest } \\
\text { protection/ } \\
\text { Climate change }\end{array}$ & $\begin{array}{l}\text { Investigations, } \\
\text { Group work }\end{array}$ & $\begin{array}{c}\text { Creativity, } \\
\text { Communication, } \\
\text { Collaboration, } \\
\text { Reasoning }\end{array}$ \\
\hline Giant dinosaurs & Evolution & $\begin{array}{l}\text { Paleontologist, } \\
\text { Biologist }\end{array}$ & $\begin{array}{c}\text { Environmental, } \\
\text { Global/ } \\
\text { Human impact on our } \\
\text { world/ } \\
\text { Climate change }\end{array}$ & $\begin{array}{l}\text { Group work, } \\
\text { Discussion }\end{array}$ & $\begin{array}{c}\text { Communication, } \\
\text { Scientific } \\
\text { reasoning, } \\
\text { Creativity }\end{array}$ \\
\hline
\end{tabular}

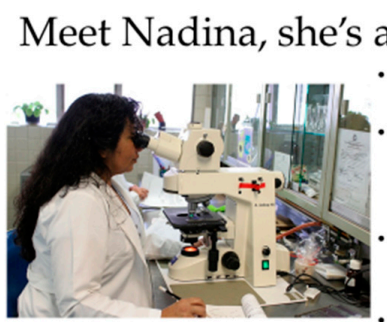

chemical design engineer

- In school Nadina studied Maths and Chemistry for A-level.

After school she did an apprenticeship in an engineering firm and then received a bursary to study in chemical engineering in University.

- She wanted to get a job in the sport industry because she wanted to do something related to people's health

- She designs products and accessories to help people with sport injuries.

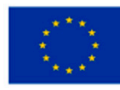

This project has received funding from the
European Union' Horizon 2020 research and
imovation programme under grant agreement

Mutic:

\section{Chemical Engineering}

You are a group of chemical engineers who work for a sports company. As part of your role, you design products that minimise sports injury. Your latest task is to design two instant sports injury packs:

- One pack needs to provide immediate relief for a sports injury that has just occurred. It needs to sooth pain and reduce swelling.

- One pack needs to provide relief for an old sports injury. It should be able to sooth a dull ache.

\section{Mušticio}

Figure 1. Chemical Design Engineer scenario. Introduction of the professional and task for the students. Source: www.multico-project.eu. Used with permission. 
Overall, students were very enthusiastic with the practical activity presented in the scenario. However, half the students reported that it did not make them want to learn more about the topic, mainly due to their lack of interest in the topic. The students who expressed a wish to learn more about it, mentioned their future career and interest. Around two thirds of the students said the scenario was enjoyable and liked its format.

In another scenario, Blackout, created by the University of Eastern Finland team, students are given cards with names of electrical devices. Later they ponder what could happen in a situation where there is no electricity. At the end of the scenario, students are familiarized with one career in the field of electricity production and distribution and design a job advertisement for that career (Figure 2). The electricity context is local or global, social, and environmental. Students are instructed to work in groups and a role-playing game has been created to support learning. Students practice collaboration and evidence-based reasoning.

BLACKOUT

- Don't reveal the device

- What kind of problems occur if the device suddenly

doesn't work anymore?

\section{Mustic웅}

\section{Unit assignment}

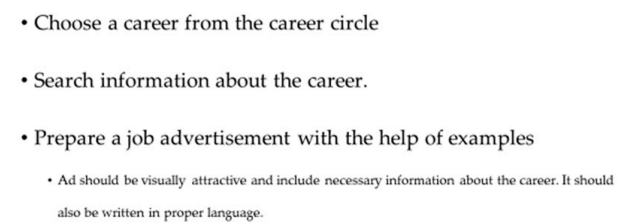

\section{Mušticío:}

Figure 2. Two slides of the Blackout scenario. The slides show two of the tasks assigned to students. Source: www.multico-project.eu. Used with permission.

The students were interested in the concepts and problems around the electricity production and distribution. The students liked the visit outside of school and learning together. In contrast, they perceived that the writing and reporting were not that interesting. However, most of the students appreciated the newly acquired knowledge about multiple careers.

The scenario Endangered Species created by the University of Tartu team includes, for example, the slides about activity IV and V (Figure 3). Students become familiar with endangered species and also with customs and environmental service careers. The scenario considers a global issue (International Trade) with social, economic, and environmental aspects. It offers possibilities for discussion about ethics, social responsibility, and climate change. The pedagogy includes role play and group work, thus promoting collaboration, communication, and evidence-based 
reasoning. This module was interesting and enjoyable for students and student feedback was very positive.

\section{Activity IV \\ Musticio}

Every team of students give a prepared detailed introduction of two endangered species of birds, two rodents and one amphibian species in the classroom of live animals from the aspects of their CITES status.

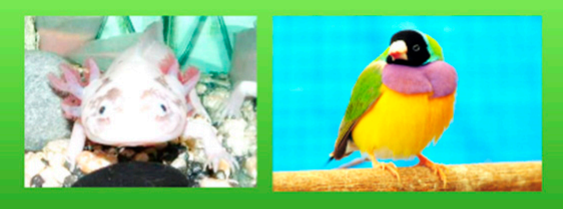

\section{Activity V \\ Musticio}

- The conclusive discussion about the CITES programme and the fulfilling worksheet about the knowledge and skills of customs officers.

- Summarising the career possibilities of customs and environmental service, the positive attitude of protection of the endangered species and the nature in general.

Figure 3. Two slides from the Endangered Species scenario. Source: www.multicoproject.eu. Used with permission.

The scenario Road Salt created by the University of Bonn team presents students with mail communication that the Mayor has received (Figure 4). Based on these messages, students need to test an alternative product for road salt and, in the process, develop familiarity with careers related to the production of an alternative product. The issue is local, social, and environmental. It is related to climate change. Students make investigations in groups as experts and practise creativity and collaboration, and particularly scientific reasoning when communicating their results. 


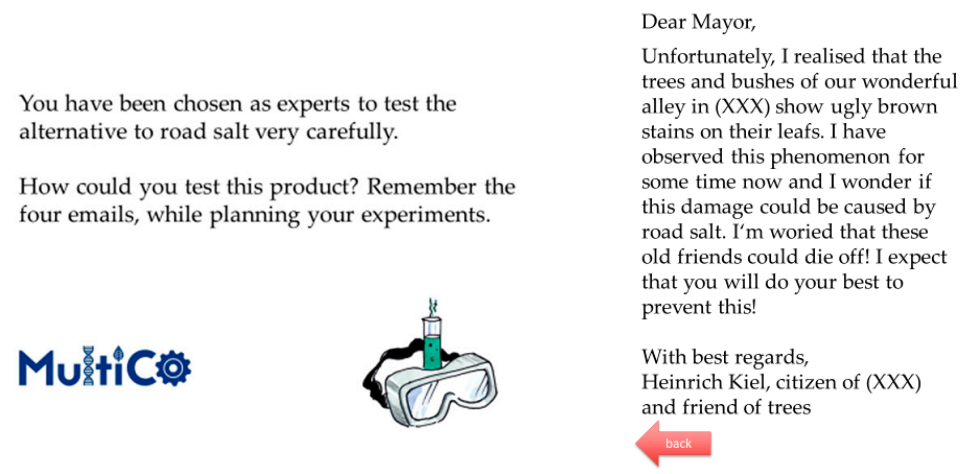

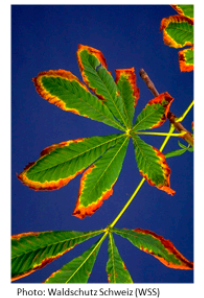

Mutstic웅

Figure 4. The scenario Road Salt introduced problems caused by road salt and invited students to test an alternative, make a decision about its suitability and present their results to the Mayor. Source: www.multico-project.eu. Used with permission.

The students perceived the topic as important for society. According to their reports, the scenario enabled them to understand the skills that are necessary in this profession. The scenario was easy to understand and it was fun to engage with. The students liked the format of the scenario.

The Zero Plastics scenario created by the University of Cyprus team considers the issue of waste generation and management. The cartoon guides students to the problem area and through the engineer's presentation the scenario introduces the task for the students (Figure 5). The issue is global, social, economic, as well as environmental. Cartoons created by the students are used to elaborate and represent the issue. Afterwards, students undertake investigations in collaborative groups.

\section{Discussion}

The EU Horizon 2020 MultiCO project focused on creating career-based scenarios as teaching-learning tools for making science education more relevant to students. In this chapter, we have introduced these scenarios in the light of sustainability. Through scenarios it was aimed to develop attractive science education and raise the students' interest in science as well as their awareness of science-related careers. Through these approaches, it is possible to influence the number of future scientists that would be in a position to engage in solving major challenges such as those related to energy, water, waste, climate change, food, health, and transport issues. All the created scenarios are related to these fields of science. Many of the scenarios are explicitly related to one or more topics associated with these domains. All of them can be connected to a sustainability issue even in those cases where that it is not 

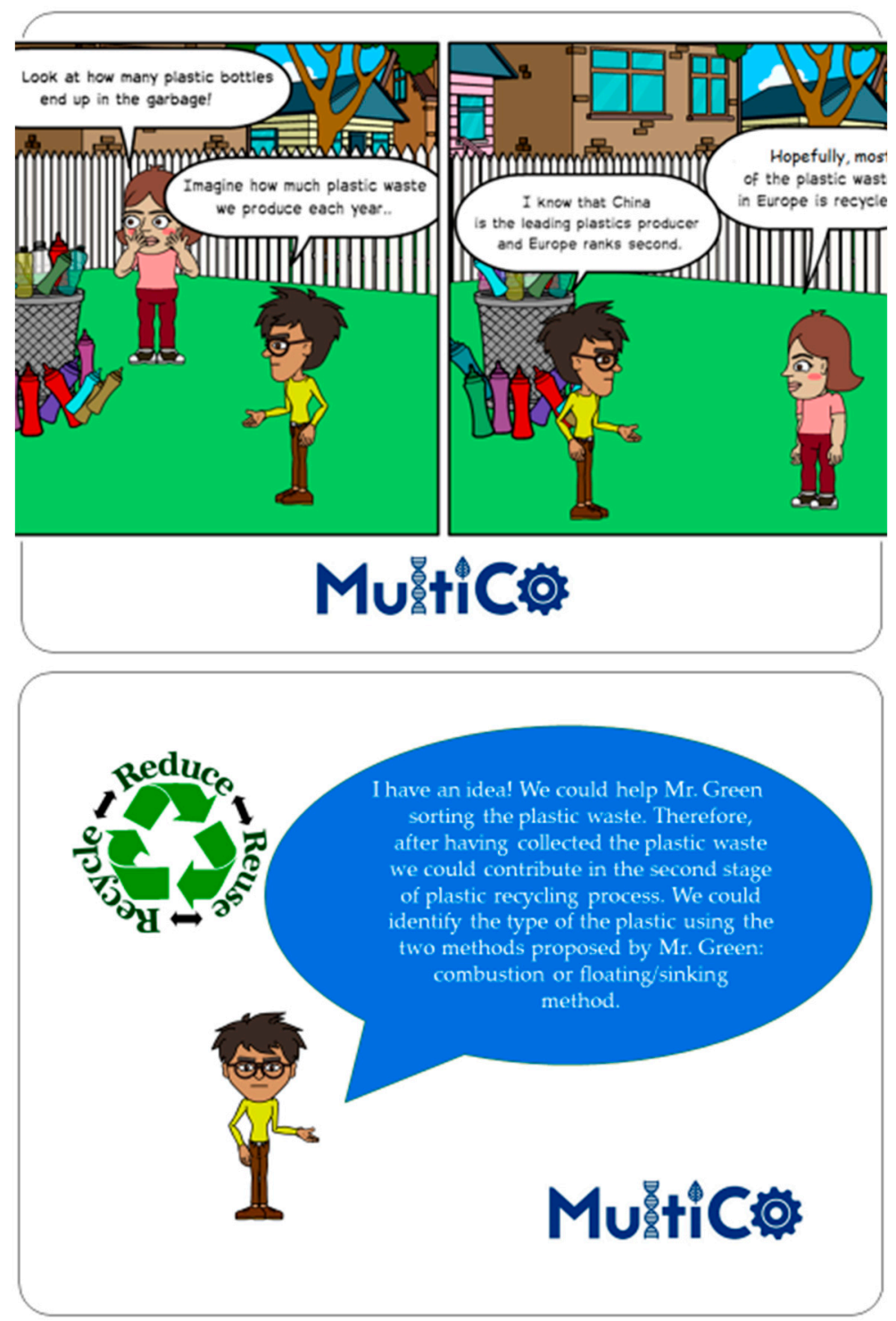

Figure 5. Slides from the Zero Plastics scenario. One innovative feature in this scenario are the cartoons created by the students. Source: www.multico-project.eu. Used with permission. 
clearly stated in the scenario. The project also aimed to strengthen the capacity of scientifically literate citizens to undertake initiative as decision-makers and social actors and thus in many of the scenarios decision-making and social participation is practiced through the supported activities. The project's career-based scenarios have always taken an approach that promotes 'education through the context of science' (European Commission 2007, 2015), they may result in improvements in attitudes towards science (cf. Bennett et al. 2007; Minner et al. 2010; Potvin and Hasni 2014) and they have been designed for nurturing a higher interest in science-related careers (cf. Reid and Skryabina 2002). Students' interest was measured after implementing five scenarios in school classrooms and it seems that the career-based scenarios as a pedagogical approach offer appropriate interventions for raising interest in science (see D5.1 and D5.2 reports, www.multico-project.eu). During the 2.5 years of the MultiCO project duration, student interest in science, after studying with five scenarios, increased significantly (D5.1). Investigating the different aspects of interest, a significant increase could be revealed for all subcomponents. However, the changes in the emotional aspect, the value aspect and knowledge aspect regarding health topics were characterized by small effect sizes, whereas the knowledge aspect regarding technology and sustainability topics showed a negligible effect size. Scenarios had strong connections with sustainability aspects, but this did not increase students' interest in sustainability topics.

Students' perceptions of scenarios were investigated with case studies involving detailed lesson observations, collection of teaching-learning artefacts as well as teacher and student interviews. Through these studies we found that, for example, after the 'Water purification' scenario, students perceived that they acquired knowledge about science, science-related careers and working life skills and they reported that they enjoyed studying chemistry and were fully engaged in learning during the intervention (Salonen et al. 2018). The students appreciated the need for professionals and their responsibilities as well as the importance of water-related issues as global and local problems, but the issue was not personally important or valuable for students. Using Life Cycle Analysis (LCA, 'Life cycle Scenario') as a context, brings individual, societal, and vocational relevance to science education (Tolppanen et al. 2019). The study shows that LCA offers the opportunity for students to see science in a real-life context and promotes discussion on ethical and moral issues, which are needed much more in science education that is standard in conventional educational practices. Students understand the importance of LCA to their life and especially to society. 
Career-based scenarios significantly raised students' awareness of career options, and introduced professionals actively working in science related fields (cf. Maltese and Tai 2011). The MultiCO scenarios consider scientific and technological developments within society, and, through scenarios, students are familiarized with research organisations and industry, as well as respective scientific careers.

MultiCO scenarios also connect educational aims to the several EU strategic priorities such as water, raw materials, energy, health, and the greenhouse effect. They contribute to promoting sustainability education even though interest in science did not increase in regard to sustainability. The scenarios aim to raise general interest and particularly enhance scientific reasoning, creative problem-solving and decision-making, local and global citizenship, socially responsible action by individuals, communication skills in a variety of forms, providing skilled young people for the next education level and later workforce for business and industry (Aikenhead 2000; Rannikmäe 2002; Holbrook and Rannikmäe 2007; Lozano et al. 2017; Bacon et al. 2011; Tilbury 2011; Laurie et al. 2016; UNESCO 2005). All the MultiCO scenarios promote collaborative group work, most of them can be used to teach evidence-based reasoning and communication and many scenarios provide opportunities for practising creativity (in designing and carrying out the inquiries) (cf. Lozano et al. 2017; Bacon et al. 2011; Tilbury 2011; Laurie et al. 2016; UNESCO 2005). These competences are taken into consideration in the evaluation of scenarios and also in the student assessment. However, the skills development is not limited to these competences. Many other skills are promoted at the same time: critical thinking, community participation, responsibility, to mention a few. Similar skills are also pointed out in sustainability education. Working life skills are promoted in all the scenarios in multifaceted ways.

In relation to ESD, MultiCO scenarios are designed to incorporate both affective and cognitive aspects of learning (cf. Laurie et al. 2016) using contexts relevant to students. The scenarios include decision-making through social learning (Wals 2011) and empower students to take action on issues related to sustainability (Mogensen and Schnack 2010). Local or global perspectives are included in the scenarios (Laurie et al. 2016). Critical thinking and analysis are also highlighted in unison (Lozano et al. 2017; Bacon et al. 2011; Tilbury 2011; Laurie et al. 2016; UNESCO 2005).

The career-based scenario approach promotes quality education, as teaching includes a sustainability content, delivered mainly in terms of local, social, and environmental contexts (Laurie et al. 2016). When the scenario is related to health issues, it also promotes healthy lives and well-being, some promote sustainable 
consumption and production patterns and some support taking actions to combat climate change and its impacts. Career awareness has been raised which may change conceptions of scientific careers (Masnick et al. 2010) and lead to study choices and choosing scientific careers (Maltese and Tai 2011). Career-based scenarios are planned to be part of science curricula as Holmegaard et al. (2014) have suggested.

As MultiCO scenarios include a combination of role models, science and technology careers in interventions, authentic tasks, contact with scientists and working collaboratively, it is reasonable that they affect positively interest, motivation, and attitudes (Potvin and Hasni 2014). The MultiCO interventions have had in some cases an effect on teachers and school culture (Salonen et al. 2018). Students mostly enjoyed studying science through scenarios which leads to enhanced interest and to intentions for future participation in science.

The MultiCO project is implemented in the Western countries; thus, the discussion about quality education may be limited to these educational contexts. However, the scenarios have also been presented to a group of Namibian teacher students and teachers, who were asked to create career-based scenarios for their purposes in Namibian science education. In discussions afterwards, the teacher students and teachers perceived the career-based scenario approach to be relevant also in the Namibian context. We may assume that the approach is also suitable and has the potential to promote quality education in developing country contexts.

\section{Conclusions}

The aim of this chapter was to introduce MultiCO career-based scenarios from the perspective of addressing sustainability. The MultiCO project's career-based scenarios focus on sustainability issues related to energy, water, waste, climate change, food, health and transport, on career awareness, on skills associated with a multitude of scientific careers and particularly on promoting collaboration, creativity and evidence-based reasoning. The aims of the MultiCO project realized through the career-based scenarios are in line with the aims of ESD and quality education. Thus, MultiCO scenarios can be used as a part of ESD in efforts to promote sustainability.

The project focused on promoting career awareness and on raising interest in science using different contexts for scenarios. Sustainability issues were included in most of the scenarios and the rest could all be used in connection with topics relating to sustainability. Scenario-based teaching increased students' interest in science in regard to sustainability issues and particularly in regard to health issues. Students enjoyed studying with scenarios and their career awareness was significantly 
enriched. The relevance of scenarios was seen by students and teachers to be more societal than individual.

Science and career aspirations were examined post-hoc, after implementations of five scenarios. The majority of participating students will continue their studies in a high school rather than vocational or other types of school. Considering students' subject choices, biology was the most popular in the case of Finland and Germany. Nevertheless, in the case of Estonia and Cyprus students' most popular subject choice was advanced mathematics. Physics was the second most popular choice in Finland, Cyprus and Estonia, whereas in Germany it was chemistry. Geography was the least popular subject choice in all these countries except Germany. Overall, it should be mentioned that students at the end of the 9th grade still seem to be unsure about their future, at least concerning concrete career aspirations. However, they seem to be very sure about the wider professional fields they perceive as attractive for their future. These aspirations seem to be mostly guided by students' interest but also by rather 'functional' aspects, such as good salary, higher employment prospects and good job security. Therefore, we can conclude that the MultiCO project targets in the right direction by fostering students interest development and career awareness.

The scenarios are published and are openly accessible on the project website. Scenarios are created to fit the needs of particular curricula and local expectations. Some of the scenarios were adapted and enacted in other partner countries and, as a result, they exist in two versions with interesting differences that relate to educational context.

Author Contributions: All the authors have contributed to the planning of the project activities and implementation of the MultiCO project and its scenarios. Original draft preparation, T.K. and K.V.; Writing—Review \& Editing, C.C., M.R., A.S. and S.S.; Project Administration, K.V.; Funding Acquisition, T.K.

Funding: This project has received funding from the European Union's Horizon 2020 research and innovation programme under grant agreement No 665100.

Acknowledgments: The authors wish to thank national MultiCO team members for their collaboration in every stage of the project and particularly those contributing significantly in the creation of scenarios: John Connelly (UK), Irene Drymiotou (Cyprus), Anssi Salonen (Finland), Regina Soobard (Estonia) and Lara Weiser (Germany).

Conflicts of Interest: The authors declare no conflict of interest. The funding sponsors had no role in the design of the study; in the collection, analyses, or interpretation of data; in the writing of the manuscript, or in the decision to publish the results. 


\section{References}

Aikenhead, Glen. 1994. What is STS Science Teaching? In STS Education. Edited by Joan Solomon and Glen. S. Aikenhead. New York: Teachers College Press, pp. 47-59.

Aikenhead, Glen. 2000. STS Science in Canada. From Policy to Student Evaluation. In Science, Technology, and Society. A Sourcebook on Research and Practise. Edited by David. D. Kumar and Daryl. E. Chubin. New York: Kluwer Academic, pp. 49-89.

Ainley, Mary, and John Ainley. 2011. A Cultural Perspective on the Structure of Student Interest in Science. International Journal of Science Education 33: 51-71. [CrossRef]

Andersen, L., and T. J. Ward. 2014. Expectancy-Value Models for the STEM Persistence Plans of Ninth-Grade, High-Ability Students: A Comparison Between Black, Hispanic, and White Students. Science Education 98: 216-42. [CrossRef]

Bacon, C. M., D. Mulvaney, T. B. Ball, E.M. DuPuis, S.R. Gliessman, R.D. Lipschutz, and A. Shakouri. 2011. The creation of an integrated sustainability curriculum and student praxis projects. International Journal of Sustainability in Higher Education 12: 193-208. [CrossRef]

Baytelman, A., K. Iordanou, and C. P. Constantinou. 2020. Epistemic beliefs and prior knowledge as predictors of the construction of different types of arguments on socioscientific issues. Journal of Research in Science Teaching, 1-29. [CrossRef]

Beier, M. E., M.H. Kim, A. Saterbak, V. Leautaud, S. Bishnoi, and J.M. Gilberto. 2019. The effect of authentic project-based learning on attitudes and career aspirations in STEM. Journal of Research in Science Teaching 56: 3-23. [CrossRef]

Bennett, J., F. Lubben, and S. Hogarth. 2007. Bringing Science to Life: A Synthesis of the Research Evidence on the Effects of Context-Based and STS Approaches to Science Teaching. Science Education 91: 347-70. [CrossRef]

Bolte, C., J. Holbrook, and F. Rauch. 2012. Inquiry-based Science Education in Europe: First Examples and Reflections from the PROFILES Project. Graz: University of Klagenfurt.

DeWitt, J., and L. Archer. 2015. Who Aspires to a Science Career? A comparison of survey responses from primary and secondary school students. International Journal of Science Education 37: 2170-2192. [CrossRef]

Eccles, J. 2009. Who Am I and What Am I Going to Do with My life? Personal and Collective Identities as Motivators of Action. Educational Psychologist 44: 78-89. [CrossRef]

Ekborg, M., C. Ottander, E. Silfver, and S. Simon. 2012. Teachers' experience of working with socio-scientific issues: A large scale and in depth study. Research in Science Education 43. [CrossRef]

European Commission. 2004. Europe needs more scientists. Report of the High Level Group on Human Resources for Science and Technology in Europe. Ispra: European Commission.

European Commission. 2007. Science Education Now: A renewed pedagogy for the future of Europe. Ispra: European Commission. 
European Commission. 2009. Challenging Futures of Science in Society. Emerging Trends and Cutting-Edge Issues. The Masis Report. Ispra: European Commission.

European Commission. 2011. Science Education in Europe: National Policies. Practices and Research. Ispra: European Commission.

European Commission. 2015. Science Education for Responsible Citizenship. Ispra: European Commission. Fadigan, K.A., and P.L. Hammrich. 2004. A Longitudinal Study of the Educational and Career Trajectories of Female Participants of an Urban Informal Science Education Program. Journal of Research in Science Teaching 41: 835-60. [CrossRef]

Finnish National Board of Education. 2016. New National Core. FNBE/2016. Available online: https://www.oph.fi/sites/default/files/documents/new-national-corecurriculum-for-basic-education.pdf (accessed on 14 July 2020).

Gill, T., and J.F. Bell. 2013. What Factors Determine the Uptake of A-level Physics? International Journal of Science Education 35: 753-72. [CrossRef]

Havu-Nuutinen, S., and T. Keinonen. 2009. Learning Electricity through STS-Learning Environment. The International Journal of Learning 16: 177-87. [CrossRef]

Hofstein, A., I. Eilks, and R. Bybee. 2011. Societal issues and their importance for contemporary science education: A pedagogical justification and the state of the art in Israel, Germany and the USA. International Journal of Science and Mathematics Education 9: 1459-83. [CrossRef]

Holbrook, J., and M. Rannikmäe. 2007. Nature of Science Education for Enhancing Scientific Literacy. International Journal of Science Education 29: 1347-62. [CrossRef]

Holmegaard, H.T., L.M. Madsen, and L. Ulriksen. 2014. To Choose or Not to Choose Science: Constructions of desirable identities among young people considering a STEM higher education programme. International Journal of Science Education 36: 186-215. [CrossRef]

Inkinen, J., C. Klager, K. Juuti, B. Schneider, K. Salmela-Aro, J. Krajcik, and J. Lavonen. 2020. High school students' situational engagement associated with scientific practices in designed science learning situations. Science Education 104: 667-692. [CrossRef]

Iordanou, K., and C.P. Constantinou. 2014. Developing pre-service teachers' evidence-based argumentation skills on socio-scientific issues. Learning and Instruction 34: 42-57. [CrossRef]

Kang, J., T. Keinonen, and A. Salonen. 2019. Role of Interest and Self-Concept in Predicting Science Aspirations: Gender Study. Research in Science Education. [CrossRef]

Laurie, R., Y. Nonoyama.Tarumi, R. McKeown, and C. Hopkins. 2016. Contributions of Education for Sustainable Development (ESD) to Quality Education: A Synthesis of Research. Journal of Education for Sustainable Development 10: 226-42. [CrossRef]

Lozano, R., M.Y. Merrill, K. Sammalisto, K. Ceulemans, and F.J. Lozano. 2017. Connecting Competences and Pedagogical Approaches for Sustainable Development in Higher Education: A Literature Review and Framework Proposal. Sustainability 9: 1889. [CrossRef] 
Lykkegaard, E., and L. Ulriksen. 2019. In and out of the STEM pipeline-A longitudinal study of a misleading metaphor. International Journal of Science Education 41: 1600-25. [CrossRef]

Maltese, A.V., and R.H. Tai. 2011. Pipeline Persistence: Examining the Association of Educational Experiences with Earned Degrees in STEM Among U.S. Students. Science Education 95: 877-907. [CrossRef]

Masnick, A.M., S. Stavros Valenti, B.D. Cox, and C.J. Osman. 2010. A Multidimensional Scaling Analysis of Students' Attitudes about Science Careers. International Journal of Science Education 32: 653-67. [CrossRef]

Mau, W-C. 2003. Factors That Influence Persistence in Science and Engineering Career Aspirations. The Career Development Quaterly 51: 234-43. [CrossRef]

Minner, D.D., A.J. Levy, and J. Century. 2010. Inquiry-Based Science Instruction- What Is It and It Matter? Results from a Research Synthesis Years 1984 to 2002. Journal of Research in Science Teaching 47: 474-96. [CrossRef]

Mogensen, F., and K. Schnack. 2010. The Action Competence Approach and the 'New' Discourses of Education for Sustainable Development, Competence and Quality Criteria. Environmental Education Research 16: 59-74. [CrossRef]

OECD. 2008. Education at a Glance. Paris: OECD.

OECD. 2017. In-Depth Analysis of the Labour Market Relevance and Outcomes of Higher Education Systems: Analytical Framework and Country Practices Report, Enhancing Higher Education System Performance. Paris: OECD.

PARSEL (Popularity and Relevance of Science Education for Scientific Literacy). 2019. Available online: http://icaseonline.net/parsel/www.parsel.uni-kiel.de/cms/indexe435. html?id=home (accessed on 6 August 2019).

Potvin, P., and A. Hasni. 2014. Interest, motivation and attitude towards science and technology at K-12 levels: A systematic review of 12 years of educational research. Studies in Science Education 50: 85-129. [CrossRef]

PROFILES (Professional Reflection-Oriented Focus on Inquiry-Based Learning and Education through Science). 2019. Available online: www.profiles-project.eu (accessed on 6 August 2019).

Rannikmäe, M. 2002. Science teachers change towards STL teaching. Journal of Baltic Science Education 2: 75-81.

Reid, N., and E. Skryabina. 2002. Attitudes towards physics. Research in Science and Technology Education 20: 67-81. [CrossRef]

Salonen, A., S. Kärkkäinen, and T. Keinonen. 2018. Career-related instruction promoting students' career awareness and interest towards science learning. Chemistry Education Research and Practice 19: 474-83. [CrossRef]

Sheldrake, R. 2018. Changes in children's science-related career aspirations from age 11 to age 14. Research in Science Education. [CrossRef] 
Simon, S., and K. Richardson. 2009. Argumentation in school science: Breaking the tradition of authoritative exposition through a pedagogy that promotes discussion and reasoning. Argumentation 23: 469-93. [CrossRef]

Simon, S., S. Erduran, and J. Osborne. 2006. Learning to teach argumentation: Research and development in the science classroom. International Journal of Science Education 28: 235-60. [CrossRef]

Stuckey, M., A. Hofstein, R. Mamlok-Naaman, and I. Eilks. 2013. The meaning of 'relevance' in science education and its implications for the science curriculum. Studies in Science Education 49: 1-34. [CrossRef]

Tilbury, D. 2011. Education for Sustainable Development: An Expert Review of Processes and Learning. Available online: https://unesdoc.unesco.org/ark:/48223/pf0000191442 (accessed on 6 August 2019).

Tolppanen, S., I. Jäppinen, S. Kärkkäinen, A. Salonen, and T. Keinonen. 2019. Relevance of Life-Cycle Assessment in Context-Based Science Education: A Case Study in Lower Secondary School. Sustainability 11: 5877. [CrossRef]

UNESCO. 2005. Contributing to a More Sustainable Future: Quality Education, Life Skills and Education for Sustainable Development. Available online: https:/unesdoc.unesco.org/ ark:/48223/pf0000141019 (accessed on 6 August 2019).

UNESCO. 2009. Review of Contexts and Structures for Education for Sustainable Development. Available online: https://unesdoc.unesco.org/ark:/48223/pf0000184944 (accessed on 6 August 2019).

UNESCO Education for Sustainable Development Goals. 2017. Learning Objectives. Available online: https://unesdoc.unesco.org/ark:/48223/pf0000247444 (accessed on 6 August 2019).

United Nations. 2015. Transforming Our World: The 2030 Agenda for Sustainable Development A/RES/70/1. Available online: https://sustainabledevelopment.un.org/sdg4 (accessed on 6 August 2019).

van Aalderen-Smeets, Sandra I., Juliette H. Walma van der Molen, and Iro Xenidou-Dervou. 2018. Implicit STEM ability beliefs predict secondary school students' STEM self-efficacy beliefs and their intention to opt for a STEM field career. Journal of Research in Science Teaching 1-21. [CrossRef]

Wals, A.E.J. 2011. Learning Our Way to Sustainability. Journal of Education for Sustainable Development 5: 177-86. [CrossRef]

(C) 2021 by the authors. Licensee MDPI, Basel, Switzerland. This article is an open access article distributed under the terms and conditions of the Creative Commons Attribution (CC BY) license (http://creativecommons.org/licenses/by/4.0/). 


\section{About the Authors}

\section{Annette Scheersoi}

Annette Scheersoi studied to become a Biology and French secondary school teacher in Bonn (D), Aachen (D) and Paris (F). Her experience involves teaching at different types of schools, including bilingual classes. Since 2005, she has been a biology teacher, trainer and researcher, first at Frankfurt University, then at the University of Cologne, and since 2013, as a Professor of Biology Education at the University of Bonn. Her research on biology learning focuses on interest development in out-of-school learning environments, such as natural history museums, botanical gardens and zoos, and involves school groups as well as families and leisure visitors (formal and informal biology learning). Currently, she is coordinating an international science education project that focuses on students' and citizens' active engagement, with socio-scientific issues related to environmental, health and sustainability themes. At the University of Bonn, she has just been elected Vice-Rector for Sustainability.

\section{Costas P. Constantinou}

C. P. Constantinou is a Professor in Science Education and Director of the Learning in Science Group at the University of Cyprus. He has published extensively on inquiry-oriented curriculum design, research-validation of teaching-learning innovations, assessment for learning and the development of transversal competencies such as modeling, investigation, argumentation and creativity. He has a PhD in Physics from the University of Cambridge and has worked at Washington State University and the University of Washington. He has been active in international educational research over a period of more than 25 years, with research interests that focus on the learning and teaching of science as a process of inquiry and the use of educational technologies for promoting critical evidence-based thinking and argumentation. The Learning in Science Group uses the results of this research in the development of online learning environments and research-validated teaching-learning sequences to promote conceptual understanding, evidence-informed reasoning and scientific thinking. Dr. Constantinou has co-ordinated a number of projects funded by the European Commission and the Cyprus Research Promotion Foundation. He has participated 
in the High Level Expert Groups that authored the reports Science Education for Responsible Citizenship in 2015 and Europe needs more Scientists! in 2004. He has served as President of the European Science Education Research Association (www.esera.org) and as Chairperson of the Executive Committee of the European Association for Research on Learning and Instruction (www.earli.org).

\section{Eija Yli-Panula}

Eija Yli-Panula, Adj., Prof., Ph.D., works as a University Research Fellow at the Department of Teacher Education at the University of Turku. Yli-Panula's PhD was in Aerobiology and she has published international articles both in Aerobiology and in Science and Sustainability Education. She has been educating student teachers as a University Lecturer and Research Fellow in Biology and Geography Pedagogy for more than 30 years. Her main current research interests are in the field of Subject Pedagogy and Sustainability Education, e.g., the landscape studies of future views of students and student teachers, and the biodiversity and sustainable development education and student teachers' competencies in sustainability. She is a member of several research groups, e.g., of the Nordic and Baltic countries and belongs to various Sustainable Development Education Steering groups and to sustainability networks.

\section{Gulseda Eyceyurt}

Gulseda Eyceyurt Turk, Ph.D. (b. 1984), is Assistant Professor at Sivas Cumhuriyet University, Faculty of Education, Department of Chemistry Education (Turkey, 2017). She previously worked as an assistant at Sivas Cumhuriyet University (from 2010). She has completed bachelor's (2008) and MS (2010) degrees, and a PhD (2017) in Chemistry Education at Gazi University (Ankara-Turkey). She conducts studies in chemistry education; in the fields of argumentation, mental image and education of special gifted students. She has co-ordinated articles, papers and books in these areas and she is the Editor-in-Chief of the Cumhuriyet International Journal of Education (CIJE). She is married and has two daughters. She can be contacted at: gulsedaeyceyurt@gmail.com. 


\section{Güliz Karaarslan Semiz}

Güliz Karaarslan Semiz (Ph.D.) has been an assistant professor at the Department of Mathematics and Science Education at Ağrı İbrahim Çeçen University in Turkey for four years. She completed her PhD at Middle East Technical University in Ankara. Her PhD is on developing systems thinking skills of preservice science teachers through outdoor-based sustainability education. Her study was awarded as the best PhD thesis of the year at Middle East Technical University in 2016. Her research interests are related to education for sustainability, science teacher education, systems thinking, outdoor learning and recently, climate crisis and digital storytelling. She has articles, book chapters and conference papers related to these areas. She has attended many workshops and conferences, both in Turkey and abroad. She has over 10 years' experience in science education.

\section{Hamdi Karakaş}

Hamdi Karakaş, Ph.D. (b. 1983), is an Assistant Professor Doctor at the Sivas Cumhuriyet University (Turkey). He completed his bachelor's degree in Division of Classroom Education at Atatürk University (Turkey) in 2005, completed his master's degree in the Department of Educational Science at the Sivas Cumhuriyet University (Turkey) in 2014, and his PhD in the Department of Primary Education at Gazi University (Turkey) in 2018. He worked as a teacher (2005-2013) at the Ministry of National Education for seven years. Then, he started working as a lecturer at Sivas Cumhuriyet University in 2013. He is still working as an assistant professor at the same university. The author's research areas are primary school education, science-environment education, socio-scientific issues and teacher training. He has publications in many international and national journals and book chapters related to these research areas.

\section{Helen Kopnina}

Dr. Helen Kopnina (Ph.D. Cambridge University, 2002) is currently employed at The Hague University of Applied Science (HHS) in the Netherlands, coordinating a Sustainable Business program and conducting research within three main areas: sustainability, environmental education and biological conservation. Helen is the 
author of over two hundred articles and (co)author and (co)editor of seventeen books. Google Scholar: https://scholar.google.nl/citations?user=pE0rWdgAAAAJ\&hl=nl

\section{Jorma Joutsenlahti}

Jorma Joutsenlahti(Ph.D., Adjunct Professor)is aSenior Lecturer in mathematics education at Tampere University in Finland. He has been a teacher and educator for over twenty years. His research interests are mathematical thinking, languaging of mathematical thinking, learning materials in mathematics education and mathematics teacher education. He has been an editor in mathematics education journals, conference proceedings books and academic books. Joutsenlahti has published several tens of peer-reviewed articles in his research areas. He acts as an editorial board member and a reviewer for several international journals.

\section{Katri Varis}

Katri Varis holds master's degrees in European Law (University of Eastern Finland) and in European Competition and Intellectual Property Law (University of Liège). She was a Project Manager of the MultiCO-project; her main responsibilities were administrative, but she also contributed to research on youth participation. Currently, she is pursuing doctoral studies in International Law at the Law School of University of Eastern Finland, with a focus on climate governance and participation. She also contributes to research in a H2020-project on EU energy, climate policies and climate governance.

\section{Kristijan Krkač}

Kristijan Krkač, Ph.D. (b. 1970), is a Professor at the Zagreb School of Economics and Management (ZSEM 2003-). Prior to joining the ZSEM, he was an Associate Professor at Faculty of Philosophy and Religious Sciences of the University of Zagreb (1996-2017). He was guest professor at Science Po Lille (France) and RISEBA University (Latvia). His research interests are mainly in business ethics, CSR and sustainability and in the philosophy of Ludwig Wittgenstein. In these areas, he has published 12 books, edited and co-edited 8 textbooks, conference proceedings, and 
as a guest editor co-edited an issue of Social Responsibility Journal. He is the author and co-author of more than 120 original scientific, professional and review articles, book chapters, and encyclopedia entries. He has published with De Gruyter, Springer, Ashgate, Emerald, and Austrian Ludwig Wittgenstein Society. He is an associate editor at Social Responsibility Journal and has served as an editorial board member and a reviewer for several international journals and conferences. His notable ideas include the pragmatic/morphological analysis of later philosophy of L. Wittgenstein, the criterion of lying by default, and the remodeled concept of corporate social irresponsibility.

\section{Maria Hofman-Bergholm}

Maria Hofman-Bergholm, Ph.L., (b. 1978) is currently working as a research and development expert at Centria University of Applied Sciences, mainly in a research project called Nordic Nature Health Hub. She has completed a Licentiate of Philosophy (Education) in 2014 and is still affiliated with Åbo Akademi University as a PhD student. Her research focus has been on teacher education and sustainability. During her doctoral studies, she has co-authored two articles and published three articles on her own, all with a focus on sustainability and education. She has also contributed to writing book chapters, and was most recently asked to contribute to a Springer book series called "Integrated Science". When she became employed at Centria University of Applied Sciences (2019-), she got involved with the training of entrepreneurs, which has extended her field of research to include areas beyond basic education and teacher training. This has broadened her research perspective and the understanding that for a sustainable future we need to change more than basic education. We need to involve the whole society and integrate different perspectives from different research areas.

\section{Martina Matišić}

Martina Matišić, MA (b. 1985), is a professor of Philosophy, Logic and Ethics at the Business High School Varaždin (2012- ) and the High School in Maruševec (2011- ), Croatia. During her work experience, she worked at several secondary schools (for a certain period of time, she lectured on a psychology course) and has professionally advanced at various conferences, education programs and seminars. The latest is related to the curriculum reform and experimental program School for 
life, through various workshops by Croatian Ministry of Science and Education, etc. She has experience in various forms of immediate educational work and various projects, and has participated in many scientific conferences, competitions, public and cultural activities of the schools. In 2018, she started postgraduate doctoral study in philosophy. Her research interests are mainly related to the issues surrounding the field of philosophy teaching, i.e., the popularization of philosophy in high schools, which includes various methods of teaching and contents of teaching and correlations of philosophy with other courses. As guest lecturer, she held several lectures on Business Ethics and Corporate Social Responsibility at the Zagreb School of Economics and Management, Croatia. She is an author of book reviews and articles in fields of philosophy. She can be contacted at: martina. matisic@gmail.com

\section{Miia Rannikmäe}

Miia Rannikmäe is a Professor and the Head of the Centre for Science Education, University of Tartu, Estonia. She has considerable experience in science education within Estonia, Europe and worldwide (Fulbright fellow-University of Iowa, USA). She is an honorary doctor at the Eastern University of Finland. She has a strong school teaching background, considerable experience in pre- and in-service teacher education, and has strong links to science teacher associations worldwide. She is the member of an EC high level group publishing a report on 'Europe needs more Scientists'. She has been running a number of EC-funded projects and Estonian research grants. Her PhD students are involved in areas such as scientific literacy, relevance, creativity/reasoning, inquiry teaching/learning and the nature of science.

\section{Päivi Perkkilä}

Päivi Perkkilä, (Ph.D., Adjunct Professor in mathematics education) is a Senior Lecturer in education (and in mathematics education) at the University of Jyväskylä in Finland. She is an experienced teacher and educator. Her research interests are 
mathematical thinking, languaging of mathematical thinking, learning materials in mathematics education, identity and view of mathematics in elementary teacher education. She has been a guest editor in mathematics education journals. Perkkilä has published several tens of peer-reviewed articles in her research areas. She acts as an editorial board member and a reviewer for several international journals.

\section{Pekka Tolonen}

Pekka Tolonen, Ph.D., works as a Lecturer at the Department of Teacher Education at the University of Turku and mainly teaches didactics of History and Religion. He graduated in General History and has a PhD in Study of Religion. He has experience in research at Institutum Romanum Finlandiae (Rome), Kalevala Institute (Turku), Department of Comparative Religion, and Department of Teacher Education, University of Turku. Since 2005, he has been part of the editorial team of Temenos - Nordic Journal of Comparative Religion.

\section{Philip Verwimp}

Philip Verwimp is Professor of Development Economics at the Université libre de Bruxelles. He previously studied economics and sociology at the univerisities of Antwerp, Leuven, and Göttigen. He was a pre-and post-doctoral fellow at Yale University. He obtained his PhD in 2003 at KU Leuven with a dissertation on development and genocide in Rwanda. In 2005, he co-founded and still co-directs the households in conflict network (www.hicn.org), which groups together scholars working on the micro-economics of conflict. He works extensively on conflict, forced displacement, fragile states, poverty, health and education in developing countries. Prof.Verwimp's academic work is published in leading journals such as the Journal of Conflict Resolution, the Journal of Peace Research, the American Economic Review, the Journal of Development Economics, etc. He consults governments and international organisations on these topics. 


\section{Sofia Vesterkvist}

Sofia Vesterkvist, Master of Philosophy, has studied biology, chemistry, mathematics and subject pedagogy at the University of Turku and biotechonology at the University of Tampere. She worked as a research assistant in the project "teachers' competencies in sustainability education".

\section{Shirley Simon}

Shirley Simon is Emeritus Professor of Science Education at University College London Institute of Education. In 1974, she began her career as a chemistry teacher, then received an award to complete a master's in ChemicalEducation at the University of Reading. She subsequently taught chemistry in London schools and gained an award to study for a doctorate in Science Education at King's College London. In 1989, she completed her doctorate, which focused on assessment innovation. She has taught research methods on masters programmes and supervised many doctoral students. Her funded research has focused on scientific enquiry, argumentation, teacher learning, students' attitudes towards science and students' career choice. She has Honorary Doctorates from Umea University, Sweden, and the University of Eastern Finland, Joensuu. In Sweden, she consulted on research and writing, and supervised doctoral students working in socio-scientific issues and epistemic cognition. In Finland, she worked with researchers on the EU-funded MultiCO project. Her recent publications include a co-edited book commissioned by the Royal Society of Chemistry on engaging learners with chemistry.

\section{Tuula Keinonen}

Tuula Keinonen (Ph.D.) is a professor in education (especially research in general education). She has research and teaching experience, both in physics and education, and has doctoral degrees in both fields. Her present research focuses on science and environmental education, and particularly on the effects of Societal Science Issues approaches in science education. She is working with her research group to discover learning environments and pedagogical methods which promote students' interests in science and science studies, as well as awareness and choices of scientific careers. Tuula Keinonen participated in the EU 7th framework project 
PROFILES in the field of science education and coordinated an EU-NPP project NEED (Northern Environmental Education Development) in environmental education and Horizon2020 project MultiCO (Promoting Youth Scientific Career Awareness and its Attractiveness through Multi-stakeholder Co-operation). She is currently supervising several doctoral students in her research fields and has published more than 80 scientific articles and teaching material for secondary school chemistry teaching. Currently she is the Head of the School of Applied Educational Sciences and Teacher Education at the University of Eastern Finland.

\section{Yasmine Bekkouche}

Yasmine Bekkouche, Ph.D. (b. 1990), is a Postdoctoral Research Fellow at the Mind and Behaviour Research Group within the Centre for the Study of African Economies, University of Oxford. Prior to this, she was a postdoctoral researcher at ECARES, ULB, in Brussels. She holds a PhD in Economics from Paris School of Economics (PSE), an MA in Public Policies and Development Economics from PSE, and an MA in Data Science from ENSAE Paris-Tech. Yasmine's primary research fields are development economics and political economy. In current projects, she works on levers to increase learning achievement in primary and pre-school in Sub-Saharan Africa and South-East Asia. She is also involved in several evaluation projects on adolescents' choices and on gender norms. She also investigates the role of money in politics-both in developed and developing countries-by studying the causal impact of campaign spending on election outcomes in multiparty democracies. 

MDPI

St. Alban-Anlage 66 4052 Basel

Switzerland

Tel. +41616837734

Fax +4161302 8918

www.mdpi.com

MDPI Books Editorial Office

E-mail: books@mdpi.com

www.mdpi.com/books

\section{MDPI}


MDPI

St. Alban-Anlage 66

4052 Basel

Switzerland

Tel: +41 616837734

Fax: +41 613028918

www.mdpi.com 